a dorutcle

ind Ir gailon Papar No. 206

Seres P, Eydrugraphio Prograss Pheports, 60

DEPARTMENT OF THE INTERTOR

NITED STATES GEOLOGICAL SURVEY

CRARTEA D. WALCOTT, DIRECTOR

SURFACE WATER SUPPLY

$\mathrm{OF}$

「 LAKES AND ST. LAWRENCE

IIVER DRAINAGES, 1906

H. K. BARROWS

A. H. HORTON

DLSTERCI HYOROORAPERR

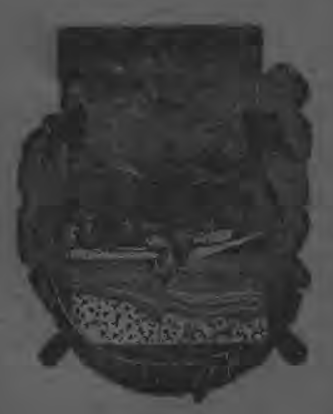

WASHINGTON

GOVERNMENT PRINTINA OFEIOR

1907 
UNITED STATES GEOLOGICAL SURVEY

CHARLES D. WALCOTT, DIRECTOR

\section{SURFACE WATER SUPPLY}

$\mathrm{OF}$

\section{GREAT LAKES ANI) S'T. LAWRENCE}

RIVER DRAINAGES, 1906

H. K. BARROWS

A. H. HORTON

DISTRICT HYDROGRAPHERS

Water Resources Branch, Geological Survey, Box 3106, Copitol Station

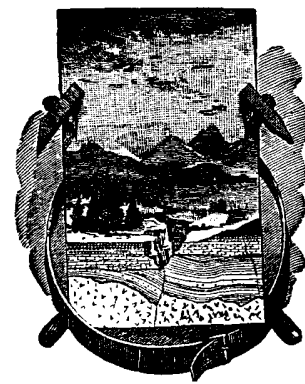
Sis.,

WA SHINGTON

GOVERNMENT PRINTING OFFICE

1907 


\section{CONTENTS.}

Introduction

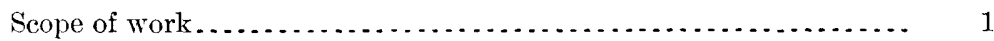

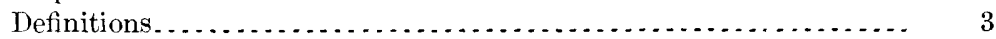

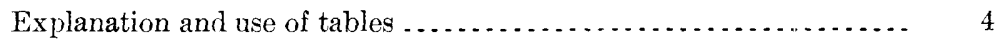

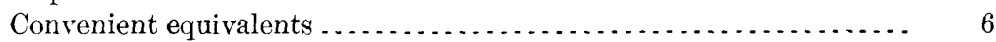

Field methods of measuring stream flow ...................

Office methods of computing run-off $\ldots \ldots \ldots \ldots \ldots \ldots \ldots \ldots \ldots \ldots \ldots$

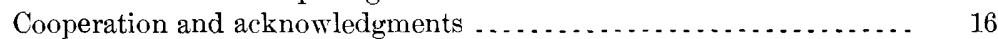

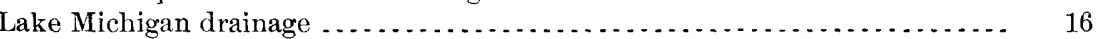

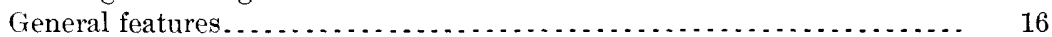

Escanaba River basin $\ldots \ldots \ldots \ldots \ldots \ldots \ldots \ldots \ldots \ldots \ldots \ldots \ldots \ldots \ldots \ldots \ldots$

Escanaba River near Escanaba, Mich................... 17

Menominee River basin................................ 18

Menominee River near Iron Mountain, Mich ................ 18

Peshtigo River drainage basin . . . . . . . . . . . . . . . . . . . . . . . . . . . 20

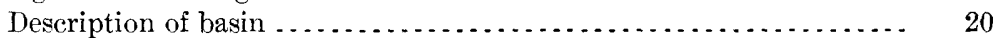

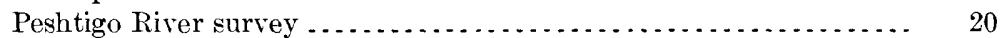

Peshtigo River at Crivitz, Wis.................................... 20

Peshtigo River at Herman's farm, near Crivitz, Wis . . . . . . . . . . 21

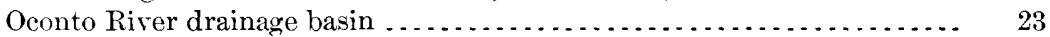

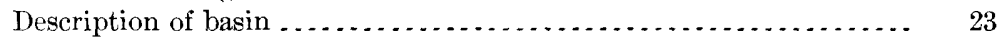

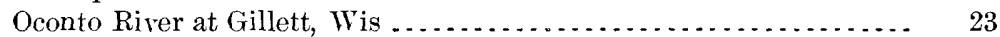

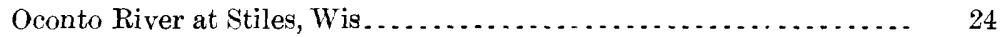

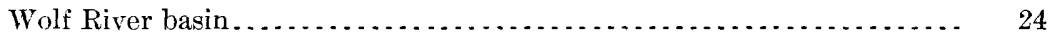

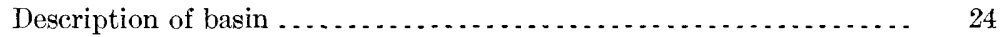

Wolf River at Darrow's bridge, near Shawano, Wis............ 25

Wolf River at White House bridge, near Shawano, Wis......... 25

St. Joseph River basin. . . . . . . . . . . . . . . . . . . . . . . . . 26

Description of basin . . . . . .

St. Joseph River at Mendon, Mich........................ 27

St. Joseph River near Buchanan, Mich. . . . . . . . . . . . . . . 27

Kalamazoo River basin . . . . . . . . . . . . . . . . . . . . . . . . 28

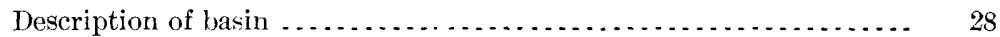

Kalamazoo River near Allegan, Mich..................... 29

Reeds Springs, near Albion, Mich....................... 30

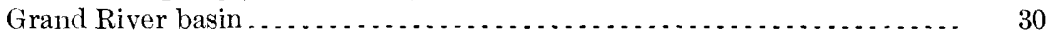

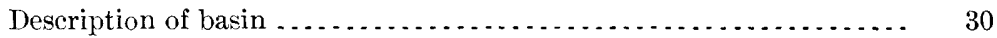

Grand River, North Lansing, Mich . . . . . . . . . . . . . . . . . 30

Grand River at Grand Rapids, Mich. . . . . . . . . . . . . . . . . . . 32

Muskegon River basin ... . . . . . . . . . . . . . . . . . . . . . . 33

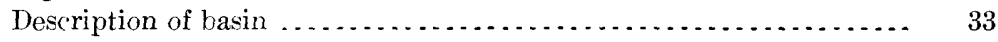

Muskegon River at Newaygo, Mich......................... 34 
Lake Michigan drainage--Continued. Page.

Manistee River basin ...................................... 35

Description of basin ................................... 35

Manistee River, near Sherman, Mich ..................... 35

Lake Huron drainage. ...................................... 36

General features............................................. 36

Au Sable River basin ....................................... 36

Description of basin . . . . .............................. 36

Au Sable River at Bamfield, Mich ......................... 36

Rifle River basin ........................................... 38

Description of basin ..................................... 38

Rifle River, near Sterling, Mich .......................... 38

Saginaw River basin ............................................. 39

Description of basin ......................................... 39

Tittabawassee River at Freeland, Mich . . ................... 39

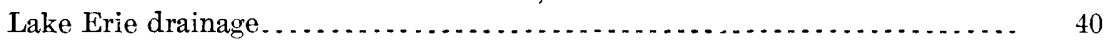

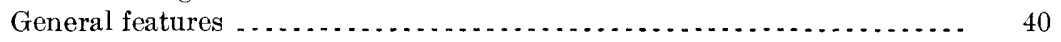

Huron River basin ..................................... 41

Description of basin ................................... 41

Huron River at Dexter, Mich . . . . . . . . . . . . . . . . . . . . . . 41

Huron River at Geddes, Mich.......................... 42

Huron River at Flatrock, Mich ........................... 42

Maumee River basin ..................................... 44

Description of basin ..................................... 44

Maumee River near Sherwood, Ohio ...................... 44

St. Joseph River at Fort Wayne, Ind ........................ 46

St. Marys River at Fort Wayne, Ind . . . . . . . . . . . . . . . . . . . 47

Tiffin River near Defiance, Ohio ........................ 49

Black River basin ....................................... 50

Black River near Elyria, Ohio ............................. 50

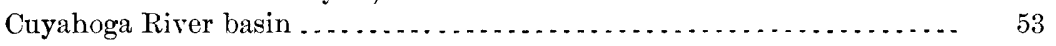

Description of basin ....................................... 53

Cuyahoga River at Independence, Ohio ..................... 53

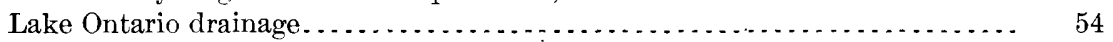

General features............................................. 54

Genessee River basin........................................ 54

Description of basin .................................... 54

Genessee River and Canaserago Creek near Mount Morris, N. Y.... 56

Genessee River at High Dam, near Mount Morris, X. Y .......... 57

Genessee River at Rochester, N. Y ........................ 58

Canadice Lake outlet near Hemlock, N. Y . . . . . . . . . . . . . 60

Honeoyo Creek at East Rush, N. Y . . . . . . . . . . . . . . . . 61

Oswego River basin . . . . . . . . . . . . . . .

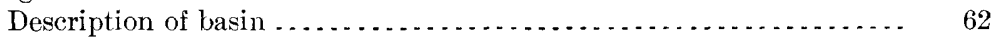

Oswego River at Battle Island, N. Y . . . . . . . . . . . . . . . . . 62

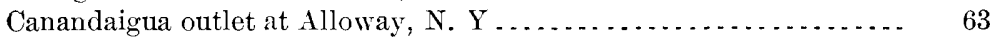

Seneca Lake at Geneva, N. Y ........................... 64

Cayuga Lake at Ithaca, N. Y . . . . . . . . . . . . . . . . . . . . . 66

Seneca River at Baldwinsville, N. Y ......................... 66

Skaneateles Lake outlet at Willow Glen, N. Y .............. 67

Oneida River near Euclid, N. Y . . . . . . . . . . . . . . ........ 69

Oneida Creek at Kenwood, N. Y ........................ 70

Chittenango Creek at Chittenango, N. Y .................... 71 
Lake Ontario drainage-Continued. Page.

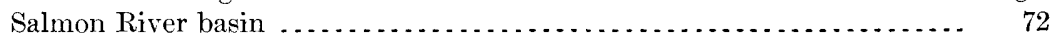

Description of basin ....................................... 72

Salmon River near Pulaski, N. Y . . . . . .

Black River basin .............................................. 75

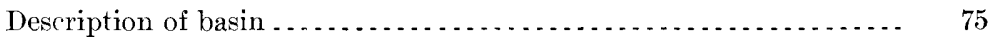

Black River near Felts Mills, N. Y . . . . . . . . . . . . .

Moose River at Moose River, N. Y . . . . . . . . . . . . .

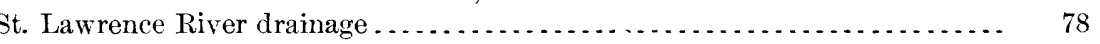

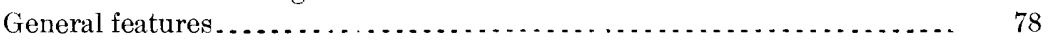

Oswegatchie River basin ........................................... 78

Description of basin ...................................... 78

Oswegatchie River near Ogdensburg, X. Y. . . . . . .

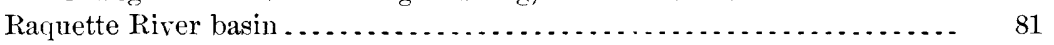

Description of basin ....................................... 81

Raquette River at Massena Springs, N. Y . . . . . . . . . . . . . . 82

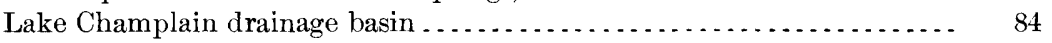

Description of basin .................................... 84

Richelieu River at Fort Montgomery, N. Y . . . . . . . . . . . . . . . 84

Saranac River near Plattsburg, N. Y...................... 86

Otter Creek at Middlebury, Vt . . . . . . . . . .

Winooski River at Richmond, Vt........................... 89 


\section{ILLUSTRATIONS.}

Plate I. Map of United States showing location of principal river stations

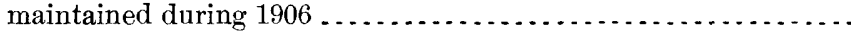

II. $A$, Current-meter rating station, Los Angeles, Cal.; $B$, Pricecurrent meters...................................... 10

III. Falls on Peshtigo River, Wis.; $A$, High Falls (40-foot fall); $B$, Caldron Falls (55-foot fall) .......................... 20

FIG. 1. Cable station, showing section of river, car, gage, etc............ 11

2. Typical discharge, area, and mean-velocity curves ............. 15 VI 


\title{
SURFACE WATER SUPPLY OF THE GREAT LAKES AND ST. LAWRENCE RIVER DRAINAGES, $1906 .^{a}$
}

\author{
H. K. Barrows and A. H. Horton, \\ District Hydrographers. ${ }^{b}$
}

\section{INTRODUCTION.}

\author{
SCOPE OF WORK.
}

The water supply of the United States is of more importance to the life and pursuits of the people than is any other natural resource. In the arid States the limit of agricultural development is determined by the amount of water available for irrigation; while in all parts of the country the increase in the population of cities and towns makes necessary additional water supplies for domestic and industrial uses, in procuring which both the quantity and the quality of the water that may be obtained must be considered. The location of manufacturing plants may depend largely on the water-power facilities and on the character of the water. The notable advances made in the electric transmission of power have led to the utilization of water powers for the operation of manufacturing establishments, railroads, and municipal lighting plants, many of which are at some distance from the places at which the power is developed.

The intelligent establishment and maintenance of enterprises or industries that depend on the use of water demands a thorough knowledge of the flow of the streams and an understanding of the conditions affecting that flow. This knowledge should be based on data showing both the total flow and the distribution of the flow throughout the year, in order that normal fluctuations may be provided for. As the flow of a stream is variable from year to year, estimates of future flow can be made only from a study of observations

$a$ This report contains information similar to that published in previous years under the title "Report on Progress of Stream Measurements."

$b$ The data presented in this report were collected as follows:

New York and New England under the direction of II. K. Barrows, assisted by Robert E. Horton and C. C. Covert.

Michigan and Wisconsin, A. I. Horton, district hydrographer, assisted by M. S. Brennan, L. S. Smith, V. II. Reineking, and D. H. Dugan.

The preparation of the data for publication has been under the direction of John C. Hoyt, assisted by R. H. Bolster, Robert Follansbee, F. F. Henshaw, J. E. Stewart, and II. D. Padgett. 
covering several years. The rapid increase in the development of the water resources of the United States has caused a great demand by engineers for information in regard to the flow of streams, as it is now generally realized that the failure of many large power, irrigation, and other projects has been due to the fact that the plans were made without sufficient trustworthy information in respect to the water supply.

Owing to the broad scope of these hydrographic investigations and the length of time they should cover in order that the records may be of greatest value, it is in general impossible for private individuals to collect the necessary data, and as many of the streams traverse more than one State this work does not properly fall within the province of the State authorities. The United States Geological Survey has therefore, by means of specific appropriations by Congress, for several years systematically made records of stream flow, with the view of ultimately determining all the important features governing the flow of the principal streams of the country. In carrying out this plan stations are established on the streams and maintained for a period long enough to show their regimen or general behavior. When a record that is sufficient for this purpose has been obtained for any stream the work on that stream is discontinued. The order in which the streams are measured is determined by the degree of their importance.

During 1906 the regimen of flow was studied at about 700 stations distributed along the various rivers throughout the United States, as shown on Pl. I. In addition to these records data in regard to precipitation, evaporation, water power, and river profiles were obtained in many sections of the country.

These data have been assembled by drainage areas, and are published in a series of fourteen Water-Supply and Irrigation Papers Nos. 201 to 214, inclusive, each of which pertains to the surface water resources of a group of adjacent areas. In these papers are embodied not only the data collected in the field, but also the results of computations based on these data, and other information that has a direct bearing on the subject, such as descriptions of basins and the streams draining them, utility of the water resources, etc. The list follows:

Water-Supply and Irrigation Papers on Surface Water Supply, 1906.

201. Surface water supply of New England, 1906 (Atlantic Coast of New England drainage).

202. Surface water supply of the Hudson, Passaic, Raritan, and Delaware river drainages, 1906.

203. Surface water supply of the Middle Atlantic States, 1906. (Susquehanna, Gunpowder, Patapsco, Potomac, James, Roanoke, and Yadkin river drainages.)

204. Surface water supply of the Southern Atlantic and Eastern Gulf States, 1906. (Santee, Savannah, Ogeechee, and Altamaha rivers and eastern Gulf of Mexico drainages.) 

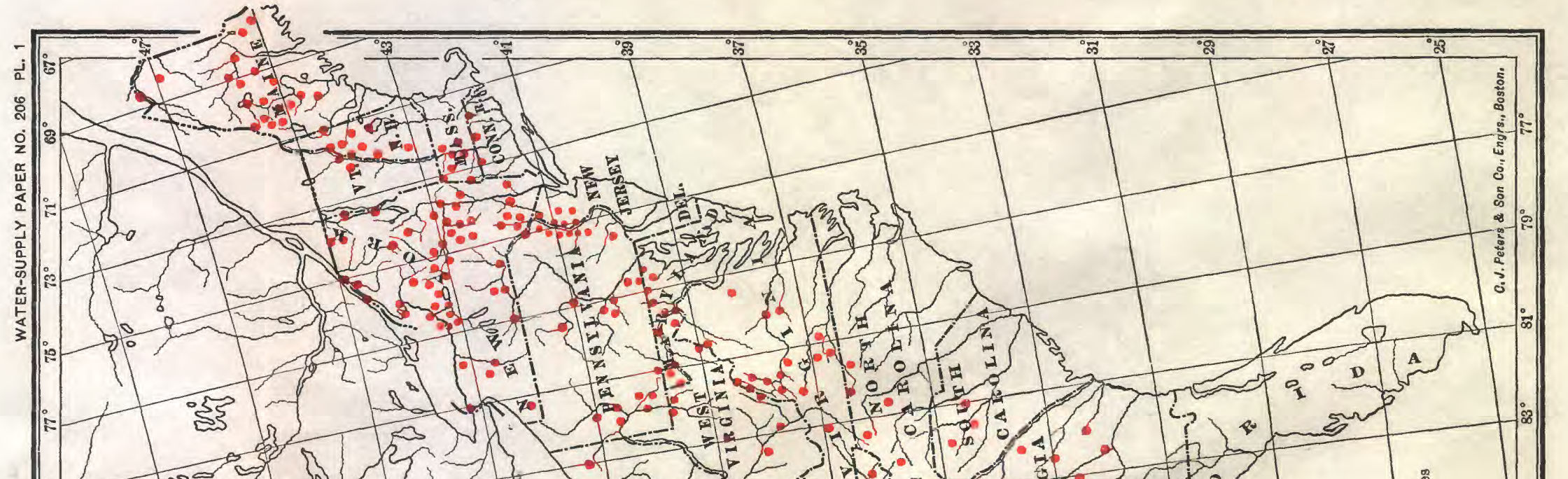

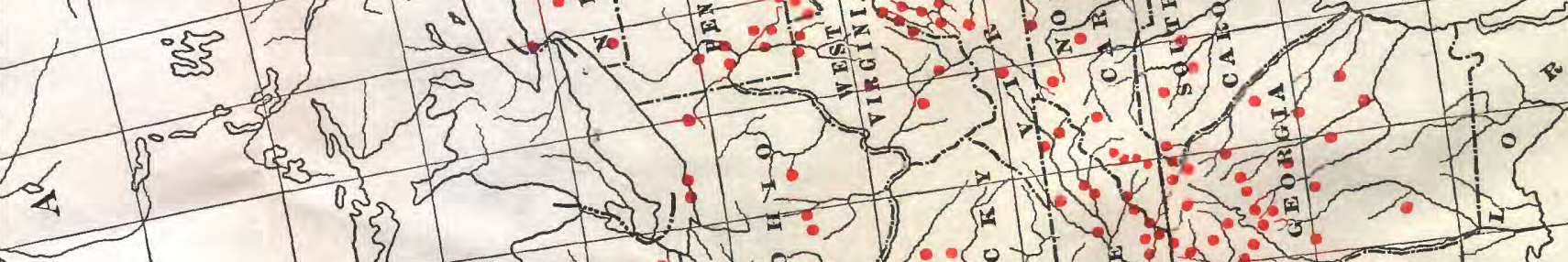

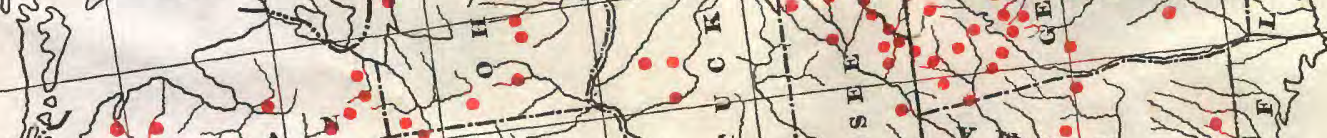

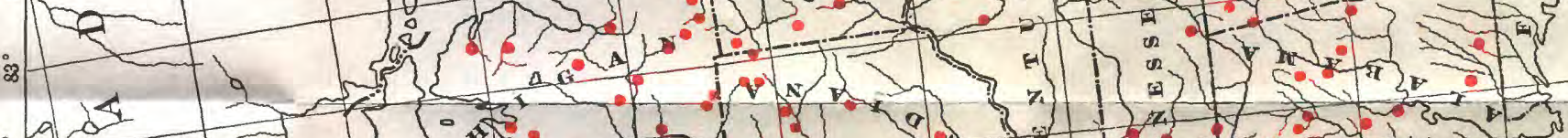

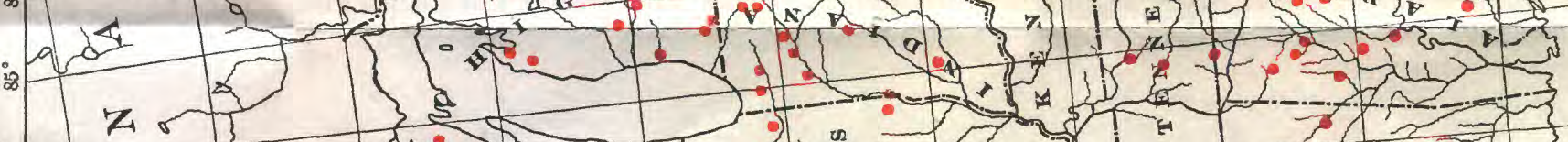

Zor (2) (2) (2) (n)

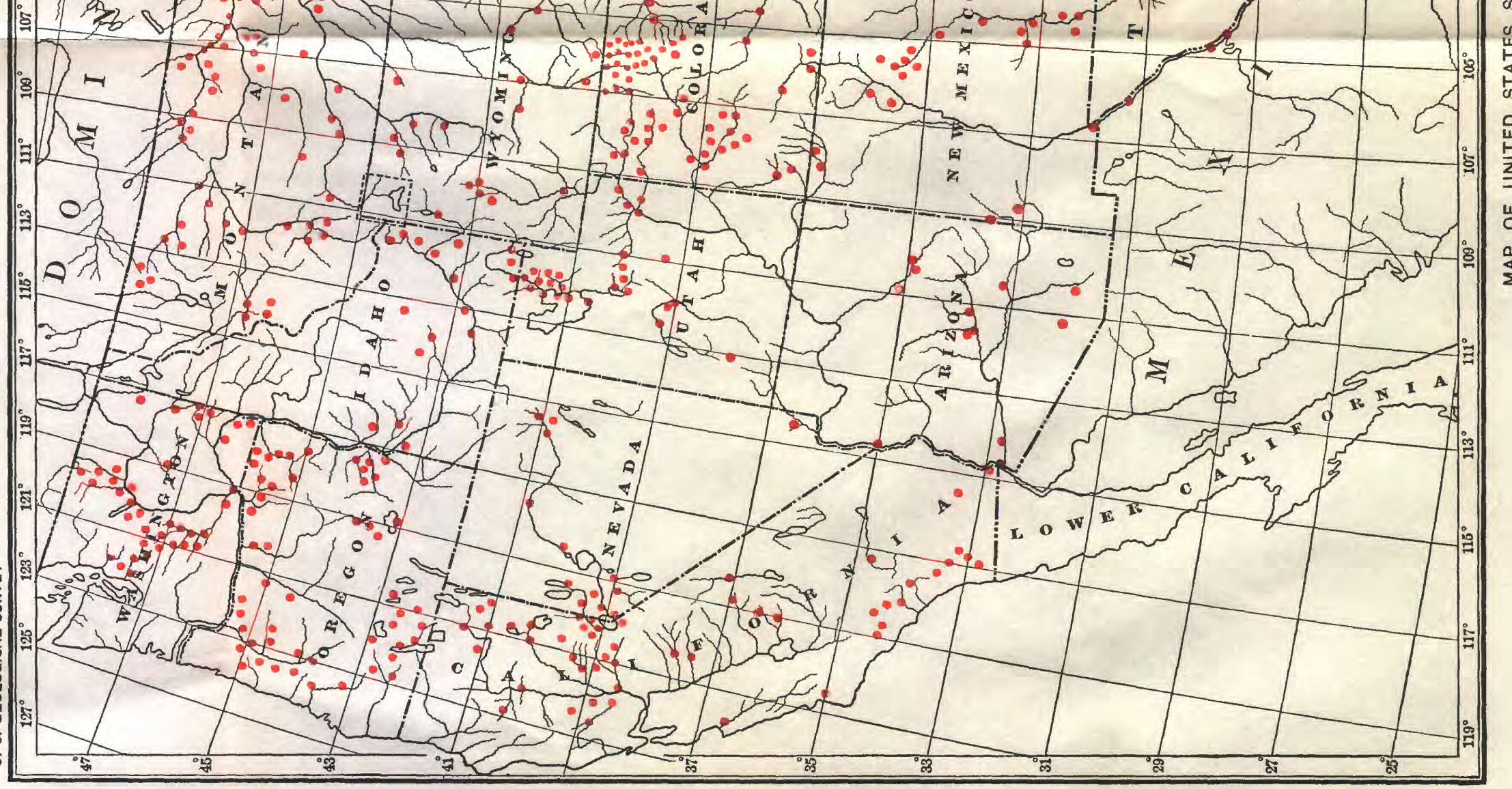


205. Surface water supply of the Ohio and lower eastern Mississippi river drainages, 1906.

206. Surface water supply of the Great Lakes and St. Lawrence River drainages, 1906.

207. Surface water supply of the upper Mississippi River and Hudson Bay drainage, 1906.

208. Surface water supply of the Missouri River drainage, 1906.

209. Surface water supply of the lower western Mississippi River drainage, 1906.

210. Surface water supply of the western Gulf of Mexico and Rio Grande drainages, 1906.

211. Surface water supply of the Colorado River drainage above Yuma, 1906.

212. Surface water supply of the Great Basin drainage, 1906.

213. Surface water supply of California, 1906. (The Great Basin and Pacific Ocean drainage in California, and Colorado River drainage below Yuma.)

214. Surface water supply of the North Pacific Coast drainages, 1906.

The records at most of the stations discussed in these reports extend over a series of years. An index of the reports containing such records up to and including 1903 has been published in Water-Supply Paper No. 119. The following table gives, by years and primary drainage basins, the numbers of the papers on the surface water supply, published from 1901 to 1906.

Numbers of water-supply papers containing results of stream measurements, 1901-1906.a

\begin{tabular}{|c|c|c|c|c|c|c|}
\hline & 1901. & 1902. & 1903. & 1904. & 1905. & 1906. \\
\hline Atlantic Coast of New England drainage.. & $\left\{\begin{array}{r}\text { No. } \\
65 \\
75\end{array}\right\}$ & $\begin{array}{l}\text { No. } \\
\quad 82\end{array}$ & $\begin{array}{r}\text { No. } \\
97\end{array}$ & $\begin{array}{l}\text { No. } \\
124\end{array}$ & $\begin{array}{l}\text { No. } \\
165\end{array}$ & $\begin{array}{l}\text { No. } \\
\quad 201\end{array}$ \\
\hline 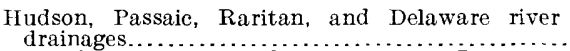 & 65 & 82 & 97 & 125 & 166 & 202 \\
\hline $\begin{array}{l}\text { Susquehanna, Gunpowder, Patapsco, Potomac, } \\
\text { James, Roanoke, and Yadkin river drainages..... }\end{array}$ & 65 & $\begin{array}{l}82 \\
83\end{array}$ & $\begin{array}{l}97 \\
98\end{array}$ & 126 & 167 & 203 \\
\hline $\begin{array}{l}\text { Santee, Savannah, Ogeechee, and Altamaha river } \\
\text { and eastern Gulf of Mexico drainages............... }\end{array}$ & 65 & 83 & 98 & 126 & 168 & 204 \\
\hline Ohio and lower eastern Mississippi river drainages... & 65 & 83 & 98 & 128 & 169 & 205 \\
\hline Great Lakes and St. Law rence River drainages...... & 65 & 83 & 97 & 129 & 170 & 206 \\
\hline $\begin{array}{l}\text { IIudson Bay and upper eqstern and western Missis- } \\
\text { sippi River drainages............................ }\end{array}$ & $\begin{array}{l}65 \\
66 \\
75\end{array}$ & $\begin{array}{l}83 \\
84 \\
85\end{array}$ & $\begin{array}{r}98 \\
99 \\
100\end{array}$ & $\begin{array}{l}128 \\
130\end{array}$ & 171 & 207 \\
\hline Missouri River drainage..... & $\begin{array}{r}66 \\
75\end{array}$ & 84 & 99 & 130 & 172 & 208 \\
\hline 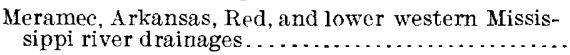 & 66 & 84 & 99 & 131 & 173 & 209 \\
\hline Western Gulf of Mexico and Rio Grande drainages.. & $\begin{array}{l}66 \\
75\end{array}$ & 84 & 99 & 132 & 174 & 210 \\
\hline Colorado River drainage above Yuma... & $\begin{array}{l}66 \\
75\end{array}$ & 85 & 100 & 133 & 175 & 211 \\
\hline The Great Basin drainage.... & $\begin{array}{l}66 \\
75\end{array}$ & 85 & 100 & 133 & 175 & 211 \\
\hline $\begin{array}{l}\text { The Great Basin and Pacific Ocean drainages in Cali- } \\
\text { fornia and Colorado River drainage below Yuma.. }\end{array}$ & $\begin{array}{l}66 \\
75\end{array}$ & 85 & 100 & 134 & 177 & 213 \\
\hline North Pacific Coast drainages............ & 75 & 85 & 100 & 135 & 178 & 214 \\
\hline
\end{tabular}

\section{DEFINITIONS.}

The volume of water flowing in a stream-the "run-off" or "discharge"-is expressed in various terms, each of which has become associated with a certain class of work. These terms may be divided into two groups-(1) those which represent a rate of flow, as secondfeet, gallons per minute, miner's inches, and run-off in second-feet

\footnotetext{
$a$ Reports containing data for years prior to 1901 are noted in the series list at the end of this paper.
} 
per square mile, and (2) those which represent the actual quantity of water, as run-off in depth in inches and acre-feet. They may be defined as follows:

"Second-foot" is an abbreviation for cubic foot per second and is the quantity of water flowing in a stream 1 foot wide, 1 foot deep, at a rate of 1 foot per second. It is generally used as a fundamental unit from which others are computed.

"Gallons per minute" is generally used in connection with pumping and city water supply.

The "miner's inch" is the quantity of water that passes through an orifice 1 inch square under a head which varies locally. It has been commonly used by miners and irrigators throughout the West and is defined by statute in each State in which it is used.

"Second-feet per square mile" is the average number of cubic feet of water flowing per second from each square mile of area drained, on the assumption that the run-off is distributed uniformly both as regards time and area.

"Run-off in inches" is the depth to which the drainage area would be covered if all the water flowing from it in a given period were conserved and uniformly distributed on the surface. It is used for comparing run-off with rainfall, which is usually expressed in depth in inches.

"Acre-foot" is equivalent to 43,560 cubic feet, and is the quantity required to cover an acre to the depth of 1 foot. It is commonly used in connection with storage for irrigation work. There is a convenient relation between the second-foot and the acre-foot: One secondfoot flowing for twenty-four hours will deliver 86,400 cubic feet, or approximately 2 acre-feet.

\section{EXPLANATION AND USE OF TABLES.}

For each regular gaging station are given, as far as available, the following data:

1. Description of station.

2. List of discharge measurements.

3. Gage-height table.

4. Rating table.

5. Table of monthly and yearly discharges and run-off.

6. Tables showing discharge and horsepower and the number of days during the year when the same are available.

The descriptions of stations give such general information about the locality and equipment as would enable the reader to find and use the station, and they also give, as far as possible, a complete history of all the changes that have occurred since the establishment of the station that would be factors in using the data collected.

The discharge-measurement table gives the results of the discharge 
measurements made during the year, including the date, the name of the hydrographer, the width and area of cross section, the gage height, and the discharge in second-feet.

The table of daily gage heights gives the daily fluctuations of the surface of the river as found from the mean of the gage heights taken each day. The gage height given in the table represents the elevation of the surface of the water above the zero of the gage. At most stations the gage is read in the morning and in the evening.

The discharge measurements and gage heights are the base data from which the other tables are computed. In cases of extensive development, it is expected that engineers will use these original data in making their calculations, as the computations made by the Survey are based on the data available at the time they are made and should be reviewed and, if necessary, revised when additional data are available.

The rating table gives the discharge in second-feet, corresponding to various stages of the river, as given by the gage heights. It is published to enable engineers to determine the daily discharge in case this information is desired.

In the table of monthly discharge the column headed "Maximum" gives the mean flow for the day when the mean gage height was highest, and it is the flow as given in the rating table for that mean gage height. As the gage height is the mean for the day, there might have been short periods when the water was higher and the corresponding discharge larger than given in this column. Likewise, in the column of "Minimum" the quantity given is the mean flow for the day when the mean gage height was lowest. The column headed "Mean" is the average flow for each second during the month. Upon this the computations for the remaining columns, which are defined on page 4, are based.

The values in the table of monthly discharge are intended to give only a general idea of the conditions of flow at the station, and it is not expected that they will be used for other than preliminary estimates.

In most work where data in regard to flow are used the regimen of flow is of primary importance. Therefore for the principal stations tables have been prepared showing the horsepower that can be developed at various rates of flow and the length of time that these rates of flow and the corresponding horsepower are available. These tables have been prepared on a basis of 80 per cent efficiency on the turbines, and the horsepower per foot of fall is given in order that the reader can determine the horsepower for any fall.

In the computations sufficient significant figures have been used so that the percentage of error in the tables will not in general exceed 1 per cent. Therefore most of the values in the tables are given to 
only three significant figures. In making the various computations Thatcher's slide rule, Crelle's tables, and computation machines have been generally used.

In order to give engineers an idea of the relative value of the various data, notes in regard to accuracy are given as far as possible. This accuracy depends on the general local conditions at the gaging stations and the amount of data collected. Every effort possible is made to so locate the stations that the data collected will give a high degree of accuracy. This is not always possible, but it is considered better to publish rough values with explanatory notes rather than no data.

In the accuracy notes the following terms have been used, indicating the probable accuracy in per cent of the mean monthly flow. As these values are mean values, the error in the value for the flow of any individual day may be much larger.

Excellent indicates that the mean monthly flow is probably accurate to within 5 per cent; good, to within 10 per cent; fair, to within 15 per cent; approximate, to within 25 per cent.

\section{CONVENIENT EQUIVALENTS.}

Following is a table of convenient equivalents for use in hydraulic computations:

1 second-foot equals 40 California miner's inches (law of March 23, 1901).

1 second-foot equals 38.4 Colorado miner's inches.

1 second-foot equals 40 Arizona miner's inches.

1 second-foot equals 7.48 United States gallons per second; equals 448.8 gallons per minute; equals 646,272 gallons for one day.

1 second-foot equals 6.23 British imperial gallons per second.

1 second-foot for one year covers 1 square mile 1.131 feet or 13.572 inches deep.

1 second-foot for one year equals $31,536,000$ cubic feet.

1 second-foot equals about 1 acre-inch per hour.

1 second-foot for one day covers 1 square mile 0.03719 inch deep.

1 second-foot for one 28-day month covers 1 square mile 1.041 inches deep.

1 second-foot for one 29-day month covers 1 square mile 1.079 inches deep.

1 second-foot for one 30 -day month covers 1 square mile 1.116 inches deep.

1 second-foot for one 31-day month covers 1 square mile 1.153 inches deep.

1 second-foot for one day equals 1.983 acre-feet.

1 second-foot for one 28 -day month equals 55.54 acre-fèet.

1 second-foot for one 29-day month equals 57.52 acre-feet.

1 second-foot for one 30 -day month equals 59.50 acre-feet.

1 second-foot for one 31-day month equals 61.49 acre-feet.

100 California miner's inches equal 15.7 United States gallons per second.

100 California miner's inches equal 96.0 Colorado miner's inches.

100 California miner's inches for one day equal 4.96 acre-feet.

100 Colorado miner's inches equal 2.60 second-feet.

100 Colorado miner's inches equal 19.5 United States gallons per second.

100 Colorado miner's inches equal 104 California miner's inches.

100 Colorado miner's inches for one day equal 5.17 acre-feet.

100 United States gallons per minute equal 0.223 second-foot. 
100 United States gallons per minute for one day equal 0.442 acre-foot.

$1,000,000$ United States gallons per day equal 1.55 second-feet.

$1,000,000$ United States gallons equal 3.07 acre-feet.

$1,000,000$ cubic feet equal 22.95 acre-feet.

1 acre-foot equals 325,850 gallons.

1 inch deep on 1 square mile equals $2,323,200$ cubic feet.

1 inch deep on 1 square mile equals 0.0737 second-foot per year.

1 foot equals 0.3048 meter.

1 mile equals 1.60935 kilometers.

1 mile equals 5,280 feet.

1 acre equals 0.4047 hectare.

1 acre equals 43,560 square feet.

1 acre equals 209 feet square, nearly.

1 square mile equals 2.59 square kilometers.

1 cubic foot equals 0.0283 cubic meter.

1 cubic foot equals 7.48 gallons.

1 cubic foot of water weighs 62.5 pounds.

1 cubic meter per minute equals 0.5886 second-foot.

1 horsepower equals 550 foot-pounds per second.

1 horsepower equals 76.0 kilogram-meters per second.

1 horsepower equals 746 watts.

1 horsepower equals 1 second-foot falling 8.80 feet.

$1 \frac{1}{3}$ horsepower equal about 1 kilowatt.

To calculate water power quickly: $\frac{\text { Sec.-ft. } \times \text { fall in feet }}{11}=$ net horsepower on water wheel, realizing 80 per cent of theoretical power.

FIELD METHODS OF MEASURING STREAM FLOW,

The methods used in collecting these data and in preparing them for publication are given in detail in Water-Supply Papers No. 94 (Hydrographic Manual, U. S. Geological Survey) and No. 95 (Accuracy of Stream Measurements). In order that those who use this report may readily become acquainted with the general methods employed, the following brief descriptions are given:

Streams may be divided, with respect to their physical conditions, into three classes-(1) those with permanent beds; (2) those with beds which change only during extreme low or high water; (3) those with constantly shifting beds. In determining the daily flow special methods are necessary for each class. The data upon which these determinations are based and the methods of collecting them are, however, in general the same.

There are three distinct methods of determining the flow of openchannel streams-(1) by measurements of slope and cross section and the use of Chezy's and Kutter's formulas; (2) by means of a weir; (3) by measurements of the velocity of the current and the area of the cross section. The method chosen for any case depends upon the local physical conditions, the degree of accuracy desired, the funds available, and the length of time that the record is to be continued. Slope method.-Much information has been collected relative to 
the coefficients to be used in the Chezy formula, $v=c \sqrt{R s}$. This has been utilized by Kutter, both in developing his formula for $c$ and in determining the values of the coefficient $n$ which appears therein. The results obtained by the slope method are, in general, only roughly approximate, owing to the difficulty in obtaining accurate data and the uncertainty of the value for $n$ to be used in Kutter's formula. The most common use of this method is in determining the flood discharge of a stream when the only data available are the cross section, the slope as shown by marks along the bank, and a knowledge of the general conditions.

Weir methods.-When funds are available and the conditions are such that sharp-crested weirs can be erected, these offer the best facilities for determining the flow. If dams are suitably situated and constructed, they may be utilized for obtaining reliable measurements of flow. The conditions necessary to insure good results may be divided into two classes-(1) those relating to the physical characteristics of the dam itself and (2) those relating to the diversion and use of water around and through the dam.

The physical requirements are as follows: (a) Sufficient height of dam, so that backwater will not interfere with free fall over it; (b) absence of leaks of appreciable magnitude; (c) topography or abutments which confine the flow over the dam at high stages; (d) level crests, which are kept free from obstructions caused by floating logs or ice; $(e)$ crests of a type for which the coefficients to be used in $Q=c b h^{\frac{3}{2}}$, or some similar standard weir formula are known (see Water-Supply Papers Nos. 180 and 200 $)$; $(f$ ) either no flash boards or exceptional care in reducing leakage through them and in recording their condition.

Preferably there should be no diversion of water through or around the dam. Generally, however, the dam is built for purposes of power or navigation and part or all of the water flowing past it is diverted for such uses. This water is measured and added to that passing over the dam. To insure accuracy in such determinations of flow the amount of water diverted should be reasonably constant. Furthermore, it should be so diverted that it can be measured, either by a weir, a current meter, or a simple system of water wheels which are of standard make, or which have been rated as meters under working conditions, and so installed that the gate openings, the heads under which they work, and their angular velocities may be accurately observed.

The combination of physical conditions and uses of the water should be such that the determinations of flow will not involve, for a critical stage of considerable duration, the use of a head, on a broad-

$a$ Water-Supply Paper No. 200 replaces No. 150, the edition of which has been exhausted. 
crested dam, of less than 6 inches. Moreover, when all other conditions are good, the cooperation of the owners or operators of the plant is still essential if reliable results are to be obtained.

A gaging station at a weir or dam has the general advantage of continuity of record through the period of ice and floods and the disadvantages of uncertainty of coefficient to be used in the weir formula and of complications in the diversion and use of the water.

Velocity method.- The determination of the quantity of water flowing past a certain section of a stream at a given time is termed a discharge measurement. This quantity is the product of two factors-the mean velocity and the area of the cross section. The mean velocity is a function of surface slope, wetted perimeter, roughness of bed, and the channel conditions at, above, and below the gaging section. The area depends upon the contour of the bed and the fluctuations of the water surface. The two principal ways of measuring the velocity of a stream are by floats and current meters.

Great care is taken in the selection and equipment of gaging stations for determining discharge by velocity measurements in order that the data may have the required degree of accuracy. Their essential requirements are practically the same whether the velocity is determined by meters or floats. They are located as far as possible where the channel is straight both above and below the gaging section; where there are no cross currents, backwater, or boils; where the bed of the stream is reasonably free from large projections of a permanent character; and where the banks are high and subject to overflow only at flood stages. The station must be so far removed from the effects of tributary streams and of dams or other artificial obstructions that the gage height shall be an index of the discharge.

Certain permanent or semipermanent structures usually referred to as equipment are generally pertinent to a gaging station. These are a gage for determining the fluctuations of the water surface, bench marks to which the datum of the gage is referred, permanent marks on a bridge or a tagged line indicating the points of measurement, and, where the current is swift, some appliance (generally a secondary cable) to hold the meter in position in the water. As a rule, the stations are located at bridges if the channel conditions are satisfactory, as from them the observations can more readily be made and the cost of the equipment is small.

The floats in common use are the surface, subsurface, and tube or rod floats. A corked bottle with a flag in the top and weighted at the bottom makes one of the most satisfactory surface floats, as it is affected but little by wind. In case of flood measurements, good results can be obtained by observing the velocity of floating cakes of ice or débris. In case of all surface-float measurements, coefficients must be used to reduce the observed velocity to the mean velocity. 
The subsurface and tube or rod floats are intended to give directly the mean velocity in the vertical. Tubes give excellent results when the channel conditions are good, as in canals.

In measuring velocity by a float, observation is made of the time taken by the float to pass over the "run," a selected stretch of river from 50 to 200 feet long. In each discharge measurement a large number of velocity determinations are made at different points across the stream, and from these observations the mean velocity for the whole section is determined. This may be done by plotting the mean positions of the floats as indicated by the distances from the bank as ordinates and the corresponding times as abscissas. A curve through these points shows the mean time of run at any point across the stream, and the mean time for the whole stream is obtained by dividing the area bounded by this curve and its axis by the width. The length of the run divided by the mean time gives the mean velocity.

The area used in float measurements is the mean of the areas at the two ends of the run and at several intermediate sections.

The essential parts of the current meters in use are a wheel of some type, so constructed that the impact of flowing water causes it to revolve, and a device for recording or indicating the number of revolutions. The relation between the velocity of the moving water and the revolutions of the wheel is determined for each meter. This rating is done by drawing the meter through still water for a given distance at different speeds and noting the number of revolutions for each run. From these data a rating table is prepared which gives the velocity per second for any number of revolutions.

Many kinds of current meters have been constructed. They may, however, be classed in two general types: Those in which the wheel is made up of a series of cups, as the Price, and those having a screw propeller wheel, as the Haskell. Each meter has been developed for use under some special condition. In the case of the small Price meter, shown in Pl. II, $A$, which has been largely developed and has been extensively used by the United States Geological Survey, an attempt has been made to get an instrument which could be used under practically all conditions.

Current-meter measurements may be made from a bridge, a cable, a boat, or by wading, and gaging stations may be classified in accordance with such use. Fig. 1 shows a typical cable station.

In making the measurement an arbitrary number of points are laid off on a line perpendicular to the thread of the stream. The points at which the velocity and depth are observed are known as measuring points, and are usually fixed at regular intervals, varying from 2 to 20 feet, depending upon the size and condition of the stream. Perpendiculars dropped from the measuring points divide the gaging section into strips. For each strip or pair of strips the mean velocity, 


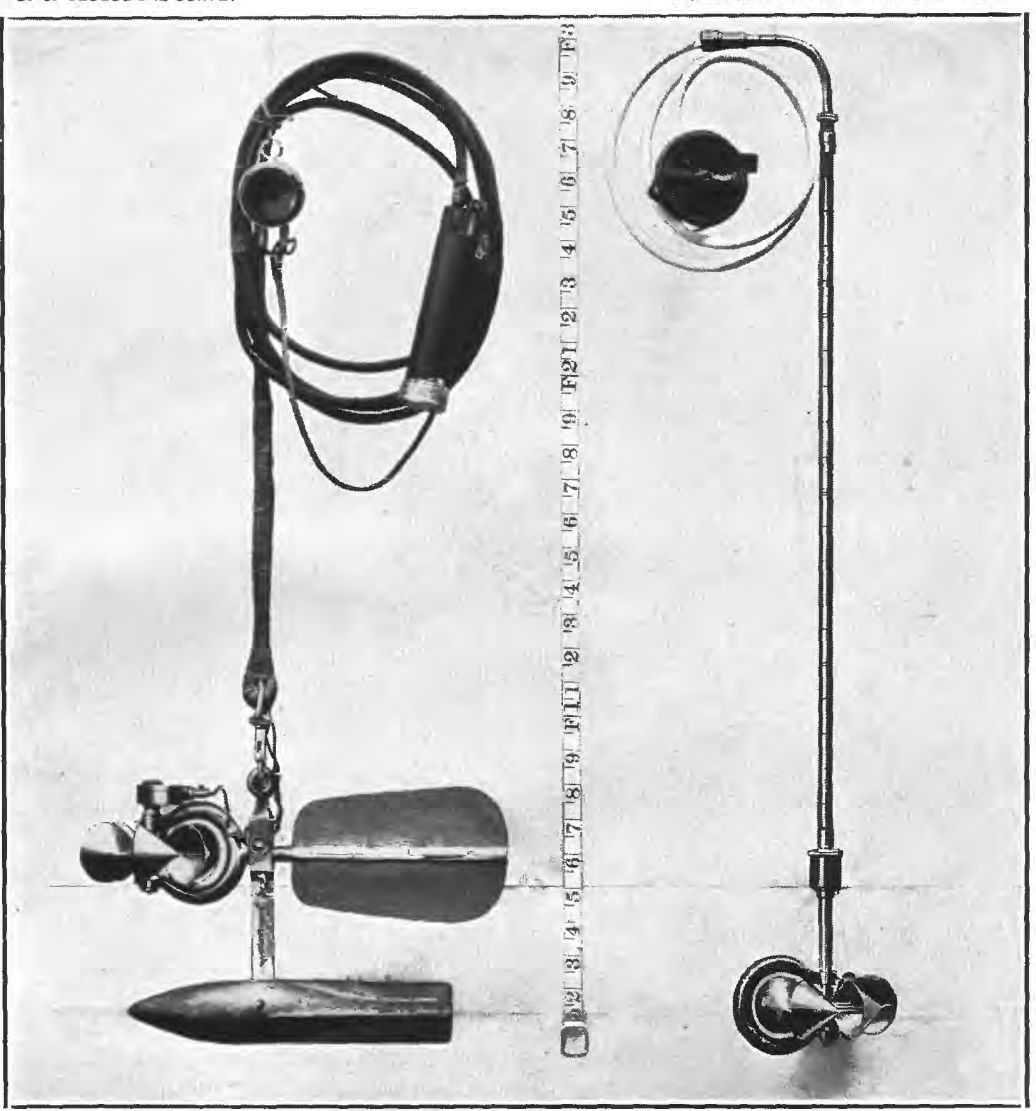

A. PRICE CURRENT METERS.

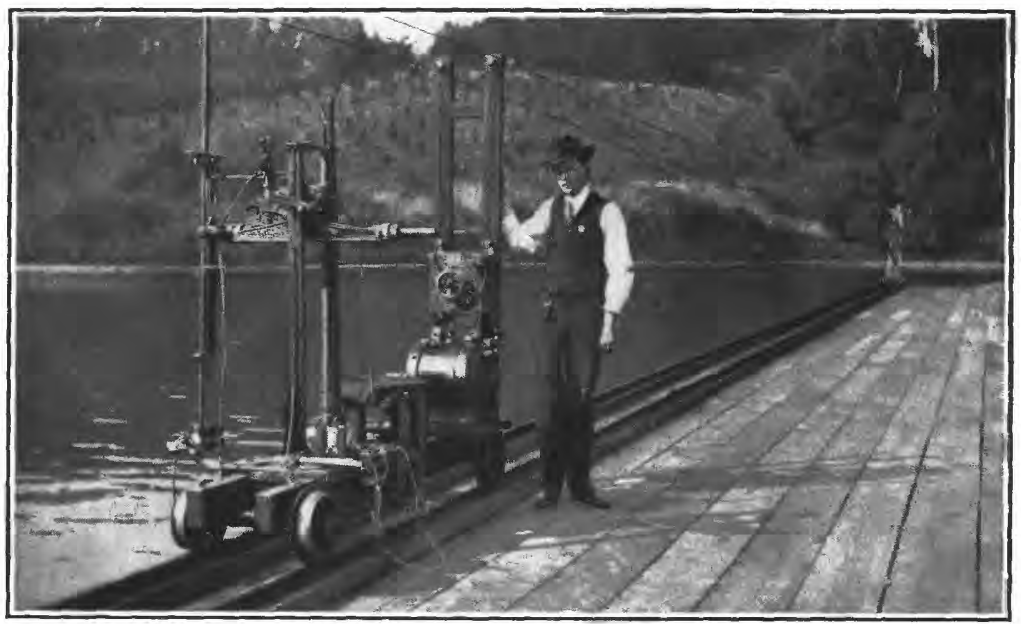

B. CURRENT-METER RATING STATION AT LOS ANGELES, CAL. 
area, and discharge are determined independently, so that conditions existing in one part of the stream may not be extended to parts where they do not apply.

Three classes of methods of measuring velocity with current meters are in general use -multiple-point, single-point, and integration.

The three principal multiple-point methods in general use are the vertical velocity-curve; 0.2 and 0.8 depth; and top, bottom, and mid-depth.

In the vertical velocity-curve method a series of velocity determinations are made in each vertical at regular intervals, usually from 0.5 to 1 foot apart. By plotting these velocities as abscissas and their depths as ordinates, and drawing a smooth curve among the resulting points, the vertical velocity-curve is developed. This curve shows graphically the magnitude and changes in velocity from the surface to the bottom of the stream. The mean velocity in the vertical is then obtained by dividing the area bounded by this velocity-curve and its axis by the depth. On account of the length

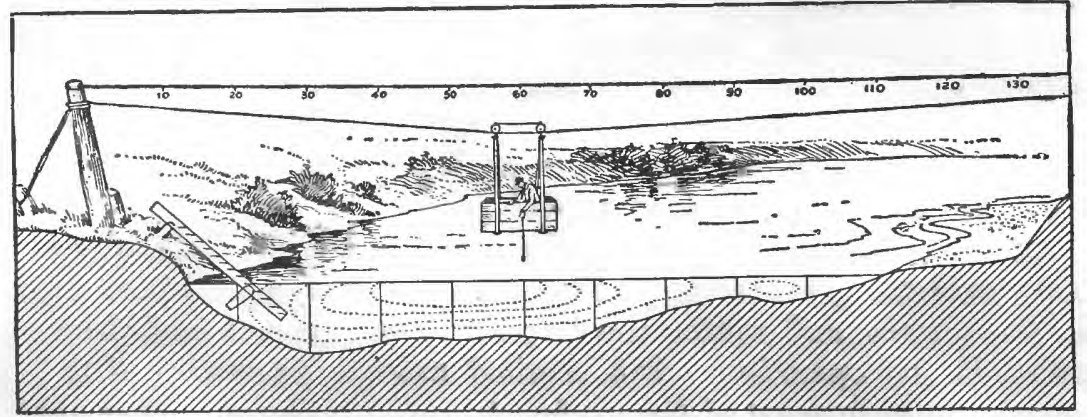

Fig. 1.-Cable station, showing section of river, car, gage, etc.

of time required to make a complete measurement by this method, its use is limited to the determination of coefficients for purposes of comparison and to measurements under ice.

In the second multiple-point method the meter is held successively at 0.2 and 0.8 of the depth, and the mean of the velocities at these two points is taken as the mean velocity for that vertical. On the assumption that the vertical velocity curve is a common parabola with horizontal axis, the mean of the velocities at 0.22 and 0.79 of the depth will give (closely) the mean velocity in the vertical. Actual observations under a wide range of conditions show that this second multiple-point method gives the mean velocity very closely for openwater conditions and, moreover, the indications are that it holds nearly as well for ice-covered rivers.

In the third multiple-point method the meter is held at mid-depth, at 0.5 foot below the surface, and at 0.5 foot above the bottom, and the mean velocity is determined by dividing by 6 the sum of the top

IRR $206-07-2$ 
velocity, four times the mid-depth velocity, and the bottom velocity. This method may be modified by observing at $0.2,0.6$, and 0.8 depth.

The single-point method consists in holding the meter either at the depth of the thread of mean velocity or at an arbitrary depth for which the coefficient for reducing to mean velocity has been determined.

Extensive experiments by vertical velocity-curves show that the thread of mean velocity generally occurs at from 0.5 to 0.7 of the total depth. In general practice the thread of mean velocity is considered to be at 0.6 depth, at which point the meter is held in a majority of the measurements. A large number of vertical velocitycurve measurements taken on many streams and under varying conditions show that the average coefficient for reducing the velocity obtained at 0.6 depth to mean velocity is practically unity.

In the other principal single-point method the meter is held near the surface, usually 1 foot below, or low enough to be out of the effect of the wind or other disturbing influences. This is known as the subsurface method. The coefficient for reducing the velocity taken at the subsurface to the mean has been found to be from 0.85 to 0.95 , depending upon the stage, velocity, and channel conditions. The higher the stage the larger the coefficient. This method is especially adapted for flood measurements, or when the velocity is so great that the meter can not be kept at 0.6 depth.

The vertical-integration method consists in moving the meter at a slow, uniform speed from the surface to the bottom and back again to the surface, and noting the number of revolutions and the time taken in the operation. This method has the advantage that the velocity at each point of the vertical is measured twice. It is useful as a check on the point methods.

The area, which is the other factor in the velocity method of determining the discharge of a stream, depends on the stage of the river, which is observed on the gage, and on the general contour of the bed of the stream, which is determined by soundings. The soundings are usually taken at each measuring point at the time of the discharge measurement, either by using the meter and cable or by a special sounding line or rod. For streams with permanent beds standard cross sections are usually taken during low water. These sections serve to check the soundings which are taken at the time of the measurements, and from them any change which may have taken place in the bed of the stream can be detected. They are also of value in obtaining the area for use in computations of high-water measurements, as accurate soundings are hard to obtain at high stages.

In computing the discharge measurements from the observed velocities and depths at various points of measurement, the measuring section is divided into elementary strips, as shown in fig. 1 , and the 
mean velocity, area, and discharge are determined separately for either a single or a double strip. The total discharge and the area are the sums of those for the various strips, and the mean velocity is obtained by dividing the total discharge by the total area.

The determination of the flow of an ice-covered stream is difficult, owing to diversity and instability of conditions during the winter period, and also to lack of definite information in regard to the laws . of flow of water under ice. The method now employed is to make frequent discharge measurements during the frozen periods by the 0.2 and 0.8 , and vertical velocity-curve methods, and to keep an accurate record of the conditions, such as the gage height to the surface of the water as it rises in a hole cut in the ice, the thickness and character of the ice, etc. From these data an approximate estimate of the daily flow can be made by constructing a rating curve (really a series of curves) similar to that used for open channels, but considering, in addition to gage heights and discharge, the varying thickness of ice. For information in regard to flow under ice cover, see Water-Supply Paper No. 187.

\section{OFFICE METHODS OF COMPUTING RUN-OFF.}

There are two principal methods of determining run-off, depending upon whether or not the bed of the stream is permanent.

For stations on streams with permanent beds, the first step in computing the run-off is the construction of a rating table, which shows the discharge corresponding to any stage of the stream. This rating table is applied to the record of stage to determine the amount of water flowing. The construction of the rating table depends upon the method used in measuring flow.

For a station at a weir or dam, the basis for the rating table is some standard weir formula. The coefficients to be used in its application depend upon the type of dam and other conditions near its crest. After inserting in the weir formula the measured length of crest and assumed coefficient, the discharge is computed for various heads and the rating table constructed.

The data necessary for the construction of a rating table for a velocity-area station are the results of the discharge measurements, which include the record of stage of the river at the time of measurement, the area of the cross section, the mean velocity of the current, and the quantity of water flowing. A thorough knowledge of the conditions at and in the vicinity of the station is also necessary.

The construction of the rating table depends upon the following laws of flow for open, permanent channels: (1) The discharge will remain constant so long as conditions at or near the gaging station remain constant; (2) the discharge will be the same whenever the stream is at a given stage if the change of slope due to the rise and fall 
of the stream be neglected; (3) the discharge is a function of and increases gradually with the stage.

The plotting of results of the various discharge measurements, using gage heights as ordinates, and discharge, mean velocity, and area as abscissas, will define curves which show the discharge, mean velocity, and area corresponding to any gage height. For the development of these curves there should be therefore a sufficient number of discharge measurements to cover the range of the stage of the stream. Fig. 2 shows a typical rating curve with its corresponding mean-velocity and area curves.

As the discharge is the product of two factors-the area and the mean velocity - any change in either factor will produce a corresponding change in the discharge. Their curves are therefore constructed in order to study each independently of the other.

The area curve can be definitely determined from accurate soundings extending to the limits of high water. It is always concave toward the horizontal axis or on a straight line, unless the banks of the stream are overhanging.

The form of the mean-velocity curve depends chiefly upon the surface slope, the roughness of the bed, and the cross section of the stream. Of these the slope is the principal factor. In accordance with the relative changes of these factors the curve may be either a straight line, convex or concave toward either axis, or a combination of the three. From a careful study of the conditions at any gaging station the form which the vertical velocity-curve will take can be predicted, and it may be extended with reasonable certainty to stages beyond the limits of actual measurements. Its principal use is in connection with the area curve in locating errors in discharge measurements and in constructing the rating table.

The discharge curve is defined primarily by the measurements of discharge, which are studied and weighted in accordance with the local conditions existing at the time of each measurement. The curve may, however, best be located between and beyond the measurements by means of curves of area and mean velocity. The discharge curve under normal conditions is concave toward the horizontal axis and is generally parabolic in form.

In the preparation of the rating table the discharge for each tenth or half tenth on the gage is taken from the curve. The differences between successive discharges are then taken and adjusted according to the law that they shall either be constant or increasing.

The determination of daily discharge of streams with changeable beds is a difficult problem. In case there is a weir or dam available, a condition which seldom exists on streams of this class, the discharge can be determined by its use. In case of velocity-area stations frequent discharge measurements must be made if the deter- 


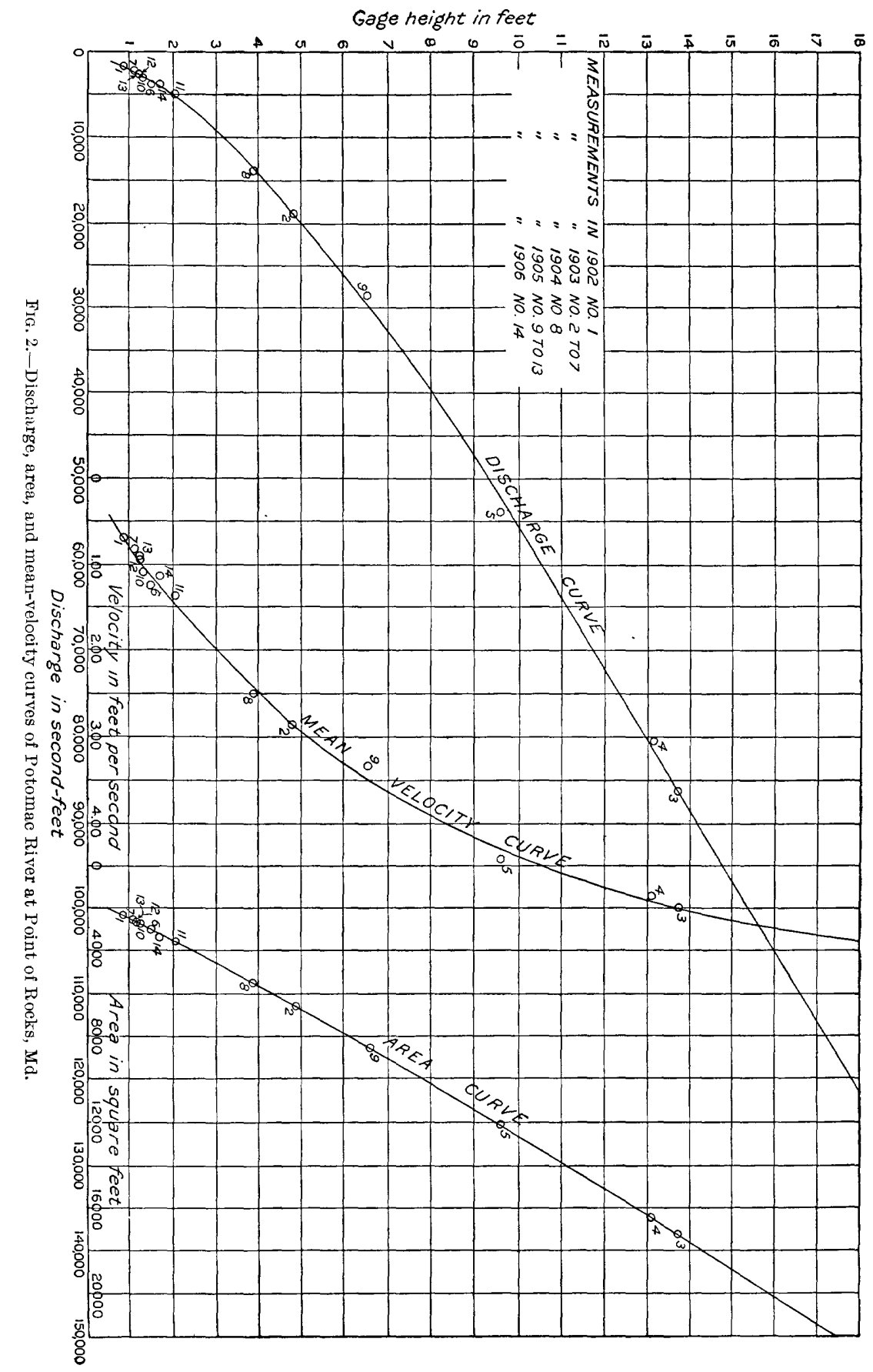


minations of flow are to be other than rough approximations. For stations with beds which shift slowly or are materially changed only during floods, rating tables can be prepared for periods between such changes and satisfactory results obtained with a limited number of measurements, provided that some of them are taken soon after the change occurs. For streams with continually shifting beds, such as the Colorado and Rio Grande, discharge measurements should be made every two or three days and the discharge for intervening days obtained either by interpolation modified by gage height or by Professor Stout's method, which has been described in full in the Nineteenth Annual Report of the United States Geological Survey, Part IV, page 323, and in the Engineering News of April 21, 1904. This method, or a graphical application of it, is also much used in determining the flow at stations where the bed shifts but slowly.

\section{COOPERATION AND ACKNOWLEDGMENTS.}

Assistance has been rendered and records furnished by the following, to whom special acknowledgment is due:

H. C. Allen, special deputy State engineer, E. A. Fisher, city engi-neer, and J. F. Skinner, special assistant engineer, Rochester, N. Y.; Utica Consolidated Paper Company, Utica, N. Y.; A. T. Safford, consulting engineer, International Paper Company, Corinth, N. Y.; R. P. Bloss, engineer, West Virginia Pulp and Paper Company, Mechanicsville, N. Y.; G. H. Beebe, deputy city engineer, Syracuse, N. Y.; Mount Morris Paper Company, Mount Morris, N. Y.; Utica Gas and Electric Light Company; Albany and Hudson River Railroad Company; J. Waldo Smith, chief engineer, and Carlton E. Davis, resident engineer, New York Additional Water Supply Commission; Kalamazoo Valley Electric Company, Kalamazoo, Mich.; Flint Land Company, Flint, Mich.; Fletcher Paper Company, Alpena, Mich.; L. W. Anderson, city engineer, Grand Rapids, Mich.; Washtenaw Electric Company, Ann Arbor, Mich.; Gardner S. Williams, Ann Arbor, Mich.; W. E. Denison, Freeland, Mich.; Cheboygan Electric Light and Power Company, Cheboygan, Mich.; Wisconsin Geological and Natural History Survey, Dr. E. A. Birge, superintendent; and D. W. Mead, Madison, Wis.

\section{LAKE MICHIGAN DRAINAGE.}

\section{GENERAL FEATURES.}

The Lake Michigan drainage basin comprises a comparatively narrow strip of flat or gently rolling land in eastern Wisconsin, on the west shore of the lake, and a much wider strip of nearly the same character in Michigan, on the east shore. The principal streams entering the lake from the west are Fox and Menominee rivers; from 
the east, St. Joseph, Kalamazoo, Grand, Muskegon, and Manistee rivers.

The following pages give the results of data collected during 1906 in the Lake Michigan drainage basin.

\section{ESCANABA RIVER BASIN.}

ESCANABA RIVER NEAR ESCANABA, MICH.

The gaging station was established in May, 1903. It is located at a highway bridge 4 miles above the mouth of the river. The conditions at this station and the bench marks are described in WaterSupply Paper No. 170, page 12, where are given also references to publications that contain data for previous years.

Discharge measurements of Escanaba River near Escanaba, Mich., in 1906.

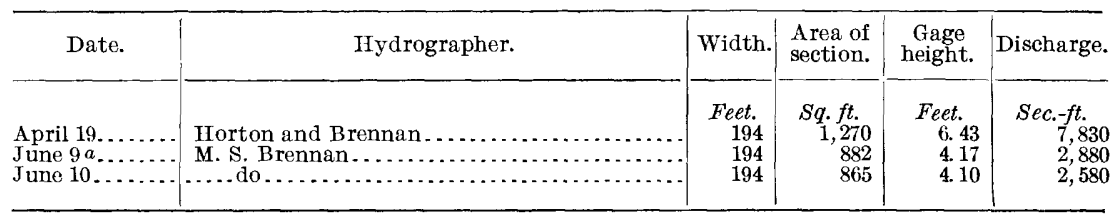

$a$ Heavy run of logs

Daily gage height, in feet, of Escanaba River near Escanaba, Mich., for 1906.

\begin{tabular}{|c|c|c|c|c|c|c|c|c|c|}
\hline Day. & Apr. & May. & June. & July. & Aug. & Sept. & Oct. & Nov. & Dec. \\
\hline 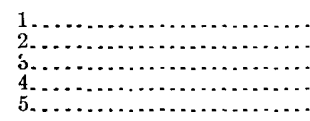 & $\begin{array}{l}\cdots \\
\cdots \\
\cdots \\
\cdots \\
\cdots\end{array}$ & $\begin{array}{l}\text { 4. } 3 \\
\text { 4. } 4 \\
\text { 4. } 5 \\
\text { 4. } 4 \\
\text { 4. } 4\end{array}$ & $\begin{array}{l}\text { 3. } 0 \\
\text { 3. } 1 \\
\text { 3. } 2 \\
\text { 3. } 3 \\
\text { 3. } 4\end{array}$ & $\begin{array}{l}\text { 3. } 3 \\
\text { 3. } 2 \\
3.0 \\
2.9 \\
2.8\end{array}$ & $\begin{array}{l}2.2 \\
2.1 \\
2.1 \\
2.2 \\
2.3\end{array}$ & $\begin{array}{l}2.2 \\
2.2 \\
2.2 \\
2.2 \\
2.1\end{array}$ & $\begin{array}{l}2.2 \\
2.2 \\
2.2 \\
2.3 \\
2.2\end{array}$ & $\begin{array}{l}2.8 \\
2.8 \\
2.7 \\
2.8 \\
2.9\end{array}$ & $\begin{array}{l}3.3 \\
3.1 \\
\text { 3. } 0 \\
2.9 \\
2.9\end{array}$ \\
\hline 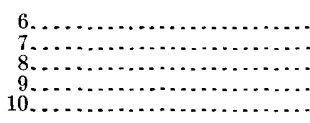 & $\begin{array}{l}4.0 \\
4.1\end{array}$ & $\begin{array}{l}4.2 \\
3.9 \\
3.9 \\
4.0 \\
3.8\end{array}$ & $\begin{array}{l}\text { 3. } 6 \\
\text { 3. } 7 \\
\text { 4. } 0 \\
\text { 4. } 1 \\
\text { 4. } 1\end{array}$ & $\begin{array}{l}2.7 \\
2.6 \\
2.6 \\
2.5 \\
2.4\end{array}$ & $\begin{array}{l}2.3 \\
2.1 \\
2.2 \\
2.3 \\
2.5\end{array}$ & $\begin{array}{l}2.1 \\
2.2 \\
2.3 \\
2.4 \\
2.5\end{array}$ & $\begin{array}{l}2.3 \\
2.3 \\
2.4 \\
2.4 \\
2.5\end{array}$ & $\begin{array}{l}2.9 \\
3.0 \\
3.1 \\
3.1 \\
3.1\end{array}$ & $\begin{array}{l}2.8 \\
2.8 \\
2.9 \\
2.9 \\
2.8\end{array}$ \\
\hline 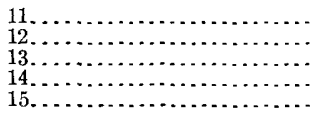 & $\begin{array}{l}\text { 4. } 3 \\
\text { 4. } 6 \\
\text { 5. } 2 \\
\text { 5. } 3 \\
\text { 5. } 3\end{array}$ & $\begin{array}{l}3.7 \\
3.5 \\
3.4 \\
3.5 \\
3.4\end{array}$ & $\begin{array}{l}\text { 4. } 0 \\
\text { 3. } 8 \\
\text { 3. } 9 \\
\text { 3. } 9 \\
\text { 3. } 7\end{array}$ & $\begin{array}{l}\text { 2. } 4 \\
\text { 3. } 4 \\
\text { 3. } 4 \\
\text { 3. } 3 \\
\text { 3. } 4\end{array}$ & $\begin{array}{l}2.4 \\
2.2 \\
2.1 \\
2.1 \\
2.3\end{array}$ & $\begin{array}{l}2.6 \\
2.8 \\
2.9 \\
2.9 \\
2.9\end{array}$ & $\begin{array}{l}2.5 \\
2.5 \\
2.3 \\
2.3 \\
2.4\end{array}$ & $\begin{array}{l}\text { 3. } 0 \\
\text { 3. } 1 \\
3.0 \\
2.8 \\
2.8\end{array}$ & $\begin{array}{l}2.8 \\
2.9 \\
2.9 \\
2.9 \\
2.9\end{array}$ \\
\hline $\begin{array}{l}16 \ldots \ldots \\
17 \ldots \ldots \ldots \\
18 \ldots \ldots \\
19 \ldots \ldots \\
20 \ldots \ldots\end{array}$ & $\begin{array}{l}5.4 \\
5.6 \\
6.2 \\
6.5 \\
6.8\end{array}$ & $\begin{array}{l}\text { 3. } 5 \\
\text { 3. } 4 \\
\text { 3. } 3 \\
\text { 3. } 2 \\
\text { 3. } 1\end{array}$ & $\begin{array}{l}3.5 \\
3.5 \\
3.4 \\
3.3 \\
3.3\end{array}$ & $\begin{array}{l}\text { 3. } 2 \\
\text { 3. } 2 \\
\text { 3. } 1 \\
\text { 3. } 0 \\
\text { 3. } 1\end{array}$ & $\begin{array}{l}2.2 \\
2.3 \\
2.1 \\
2.1 \\
2.4\end{array}$ & $\begin{array}{l}\text { 3. } 1 \\
\text { 3. } 1 \\
\text { 3. } 1 \\
\text { 3. } 0 \\
\text { 3. } 0\end{array}$ & $\begin{array}{l}2.5 \\
2.4 \\
2.4 \\
2.3 \\
2.4\end{array}$ & $\begin{array}{l}2.9 \\
2.9 \\
2.8 \\
2.7 \\
2.8\end{array}$ & $\begin{array}{l}2.8 \\
2.9 \\
2.8 \\
2.8 \\
2.9\end{array}$ \\
\hline $\begin{array}{l}21, \ldots \ldots \\
22 \\
23, \ldots \ldots \\
24 \ldots \\
25 \ldots \ldots\end{array}$ & $\begin{array}{l}6.9 \\
6.8 \\
5.9 \\
5.8 \\
5.5\end{array}$ & $\begin{array}{l}3.1 \\
\text { 3. } 2 \\
\text { 3. } 3 \\
\text { 3. } 4 \\
3.5\end{array}$ & $\begin{array}{l}\text { 3. } 2 \\
\text { 3. } 3 \\
\text { 3. } 4 \\
\text { 3. } 4 \\
\text { 3. } 6\end{array}$ & $\begin{array}{l}2.9 \\
2.8 \\
2.7 \\
2.5 \\
2.3\end{array}$ & $\begin{array}{l}2.4 \\
2.3 \\
2.2 \\
2.2 \\
2.1\end{array}$ & $\begin{array}{l}2.9 \\
2.9 \\
2.8 \\
2.7 \\
2.7\end{array}$ & $\begin{array}{l}2.3 \\
2.2 \\
2.2 \\
2.3 \\
2.2\end{array}$ & $\begin{array}{l}2.9 \\
2.9 \\
2.8 \\
2.9 \\
3.0\end{array}$ & $\begin{array}{l}2.9 \\
2.9 \\
(a)^{2.9} \\
\cdots \ldots . . .\end{array}$ \\
\hline 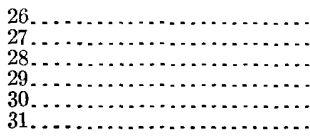 & \begin{tabular}{r|}
5.1 \\
5.1 \\
4.7 \\
4.5 \\
4.3 \\
-
\end{tabular} & $\begin{array}{l}\text { 3. } 4 \\
\text { 3. } 3 \\
\text { 3. } 3 \\
\text { 3. } 4 \\
\text { 3. } 3 \\
\text { 3. } 2\end{array}$ & $\begin{array}{l}3.7 \\
3.2 \\
3.7 \\
3.5 \\
3.4\end{array}$ & $\begin{array}{l}2.2 \\
2.1 \\
2.2 \\
2.1 \\
2.1 \\
2.2\end{array}$ & $\begin{array}{l}2.3 \\
2.3 \\
2.4 \\
2.2 \\
2.2 \\
2.3\end{array}$ & $\begin{array}{r}2.6 \\
2.6 \\
2.5 \\
2.4 \\
2.2 \\
\ldots . . .\end{array}$ & $\begin{array}{l}2.2 \\
2.3 \\
2.4 \\
2.5 \\
2.5 \\
2.6\end{array}$ & $\begin{array}{r}3.1 \\
3.2 \\
\text { 2. } 1 \\
3.1 \\
3.0 \\
. . .\end{array}$ & 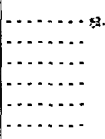 \\
\hline
\end{tabular}

a Frozen. 
Rating table for Escanaba River near Escanaba, Mich., for 1906.

\begin{tabular}{|r|r|r|r||r|r|r|r|}
\hline $\begin{array}{r}\text { Gage } \\
\text { height. }\end{array}$ & $\begin{array}{r}\text { Dis- } \\
\text { charge. }\end{array}$ & $\begin{array}{c}\text { Gage } \\
\text { height. }\end{array}$ & $\begin{array}{c}\text { Dis- } \\
\text { charge. }\end{array}$ & $\begin{array}{r}\text { Gage } \\
\text { height. }\end{array}$ & $\begin{array}{r}\text { Dis- } \\
\text { charge. }\end{array}$ & $\begin{array}{r}\text { Gage } \\
\text { height. }\end{array}$ & $\begin{array}{r}\text { Dis- } \\
\text { charge. }\end{array}$ \\
\cline { 1 - 6 } Feet. & Sec.-ft. & Feet. & Sec.-ft. & Feet. & Sec.-ft. & Feet. & Sec.-ft. \\
2.10 & 320 & 3.10 & 1,180 & 4.10 & 2.530 & 5.20 & 4,460 \\
2.20 & 385 & 3.20 & 1,300 & 4.20 & 2,690 & 5.40 & 4,870 \\
2.30 & 450 & 3.30 & 1,420 & 4.30 & 2,850 & 5.60 & 5,330 \\
2.40 & 520 & 3.40 & 1,550 & 4.40 & 3,010 & 5.80 & 5,850 \\
2.50 & 600 & 3.50 & 1,680 & 4.50 & 3,180 & 6.00 & 6,420 \\
2.60 & 680 & 3.60 & 1,810 & 4.60 & 3,350 & 6.20 & 7,040 \\
2.70 & 770 & 3.70 & 1,950 & 4.70 & 3,520 & 6.40 & 7,730 \\
2.80 & 860 & 3.80 & 2,090 & 4.80 & 3.700 & 6.60 & 8,500 \\
2.90 & 960 & 3.90 & 2,230 & 4.90 & 3,880 & 6.80 & 9,300 \\
3.00 & 1,070 & 4.00 & 2,380 & 5.00 & 4,070 & 7.00 & 10,170 \\
\hline
\end{tabular}

NotE.-The above table is applicable only for open-channel conditions. It is based on discharge measurements made during 1903-1906, and is weIl defined between gage heights 2.7 feet and 4.6 feet.

Monthly discharge of Escanaba River near Escanaba, Mich., for 1906.

[Drainage area, 800 square miles.]

\begin{tabular}{|c|c|c|c|c|c|}
\hline \multirow[b]{2}{*}{ Month. } & \multicolumn{3}{|c|}{ Discharge in second-feet. } & \multicolumn{2}{|c|}{ Run-off. } \\
\hline & Maximum. & Minimum. & Mean. & $\begin{array}{l}\text { Sec.-ft. per } \\
\text { sq. mile. }\end{array}$ & $\begin{array}{l}\text { Depth in } \\
\text { inches. }\end{array}$ \\
\hline 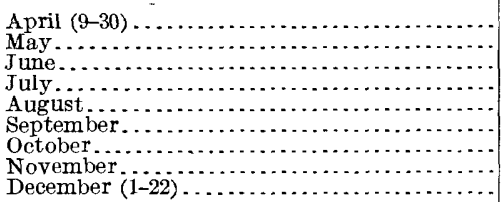 & $\begin{array}{r}9,720 \\
3,180 \\
2,520 \\
1,550 \\
600 \\
1,180 \\
680 \\
1,300 \\
1,420\end{array}$ & $\begin{array}{r}2,380 \\
1,180 \\
1,070 \\
320 \\
320 \\
320 \\
385 \\
770 \\
860\end{array}$ & $\begin{array}{r}5,170 \\
1,870 \\
1,750 \\
879 \\
411 \\
714 \\
485 \\
1,000 \\
964\end{array}$ & \begin{tabular}{l|}
6.46 \\
2.34 \\
2.19 \\
1.10 \\
.514 \\
.892 \\
.606 \\
1.25 \\
1.20
\end{tabular} & $\begin{array}{r}5.29 \\
2.70 \\
2.44 \\
1.27 \\
.59 \\
1.00 \\
.70 \\
1.40 \\
.98\end{array}$ \\
\hline
\end{tabular}

NoTE.-Values are rated as follows: May and June, excellent; remainder of the period, good.

\section{MENOMINEE RIVER BASIN.}

MENOMINEE RIVER NEAR IRON MOUNTAIN, MICH.

This station was established September 4, 1902. It is located at the Homestead highway bridge, 3.5 miles south of Iron Mountain, Mich. The conditions at this station and the bench marks are described in Water-Supply Paper No. 170, page 14, where are given also references to publications that contain data for previous years.

Discharge measurements of Menominee River near Iron Mountain, Mich., in 1906. .

\begin{tabular}{|c|c|c|c|c|c|}
\hline Date. & Hydrographer. & Width. & $\begin{array}{l}\text { A rea of } \\
\text { section. }\end{array}$ & $\begin{array}{c}\text { Gage } \\
\text { height. }\end{array}$ & Discharge. \\
\hline $\begin{array}{l}\text { April } 18 . . \\
\text { April } 18 \ldots \\
\text { June } 8 a \ldots \\
\text { June } 9 a \ldots\end{array}$ & 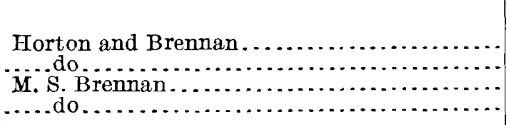 & $\begin{array}{r}\text { Feet. } \\
244 \\
244 \\
238 \\
238\end{array}$ & $\begin{array}{r}\text { Sq. ft. } \\
3,210 \\
3,250 \\
2,960 \\
2,820\end{array}$ & $\begin{array}{l}\text { Feet. } \\
11.51 \\
11.67 \\
10.45 \\
9.92\end{array}$ & $\begin{array}{r}\text { Sec. }-f t . \\
10,900 \\
11,200 \\
8,750 \\
8,030\end{array}$ \\
\hline
\end{tabular}

a Discharge slightly affected by run of logs. 
Daily gage height, in feet, of Menominee River near Iron Mountain, Mich., for 1906.

\begin{tabular}{|c|c|c|c|c|c|c|c|c|c|c|}
\hline Day. & Jan. & Feb. & Mar. & Apr. & May. & June. & July. & Aug. & Sept. & Oct. \\
\hline $\begin{array}{l}1 \ldots \ldots \ldots \ldots \\
2 \ldots \ldots \ldots \ldots \\
3 \ldots \ldots \ldots \ldots \\
4 . \ldots \ldots \ldots \\
5 . \ldots \ldots \ldots\end{array}$ & $\begin{array}{l}2.48 \\
2.42 \\
2.4 \\
2.5 \\
2.5\end{array}$ & $\begin{array}{l}\text { 4. } 55 \\
4.1 \\
4.0 \\
4.05 \\
4.0\end{array}$ & $\begin{array}{l}3.0 \\
3.0 \\
2.95 \\
2.9 \\
2.8\end{array}$ & $\begin{array}{l}3.8 \\
3.9 \\
4.3 \\
4.75 \\
4.9\end{array}$ & $\begin{array}{l}8.5 \\
9.0 \\
9.4 \\
9.5 \\
9.8\end{array}$ & $\begin{array}{l}8.8 \\
6.8 \\
7.0 \\
5.1 \\
7.0\end{array}$ & $\begin{array}{l}9.2 \\
8.3 \\
7.5 \\
8.6 \\
6.4\end{array}$ & $\begin{array}{l}2.7 \\
2.9 \\
2.65 \\
2.4 \\
2.7\end{array}$ & $\begin{array}{l}2.6 \\
3.6 \\
3.1 \\
2.8 \\
2.65\end{array}$ & $\begin{array}{l}2.9 \\
2.25 \\
2.3 \\
2.4 \\
2.5\end{array}$ \\
\hline 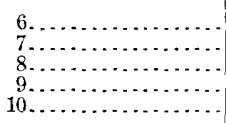 & $\begin{array}{l}2.6 \\
2.58 \\
2.5 \\
2.4 \\
2.4\end{array}$ & $\begin{array}{l}3.9 \\
3.8 \\
3.75 \\
3.6 \\
3.55\end{array}$ & $\begin{array}{l}2.82 \\
2.9 \\
2.82 \\
2.9 \\
2.9\end{array}$ & $\begin{array}{l}4.92 \\
5.0 \\
5.05 \\
5.35 \\
6.1\end{array}$ & $\begin{array}{l}9.1 \\
8.2 \\
8.5 \\
7.6 \\
7.3\end{array}$ & $\begin{array}{r}6.0 \\
8.4 \\
10.7 \\
11.3 \\
10.3\end{array}$ & $\begin{array}{l}6.2 \\
4.1 \\
4.0 \\
3.6 \\
4.75\end{array}$ & $\begin{array}{l}3.75 \\
4.25 \\
4.0 \\
3.8 \\
3.5\end{array}$ & $\begin{array}{l}2.5 \\
2.3 \\
2.4 \\
2.6 \\
2.1\end{array}$ & $\begin{array}{l}2.45 \\
2.4 \\
2.5 \\
2.6 \\
2.55\end{array}$ \\
\hline $\begin{array}{l}11 \ldots \ldots \ldots \\
12 \ldots \ldots \ldots \\
13 \ldots \ldots \\
14 \ldots \ldots \\
15 \ldots \ldots \ldots\end{array}$ & $\begin{array}{l}2.3 \\
2.4 \\
2.85 \\
3.45 \\
3.6\end{array}$ & \begin{tabular}{l|}
3.4 \\
3.4 \\
3.42 \\
3.4 \\
3.3
\end{tabular} & $\begin{array}{l}3.0 \\
3.05 \\
3.1 \\
3.0 \\
3.0\end{array}$ & $\begin{array}{l}7.15 \\
7.9 \\
8.25 \\
8.9 \\
10.6\end{array}$ & $\begin{array}{l}7.8 \\
7.1 \\
7.2 \\
6.1 \\
6.2\end{array}$ & $\begin{array}{l}8.1 \\
7.7 \\
6.7 \\
4.6 \\
3.7\end{array}$ & $\begin{array}{l}\text { 4. } 4 \\
4.3 \\
3.9 \\
4.1 \\
4.6\end{array}$ & $\begin{array}{l}3.2 \\
3.3 \\
2.75 \\
2.4 \\
2.5\end{array}$ & $\begin{array}{l}2.0 \\
2.4 \\
4.0 \\
3.8 \\
3.7\end{array}$ & $\begin{array}{l}2.75 \\
2.65 \\
2.7 \\
2.75 \\
2.4\end{array}$ \\
\hline $\begin{array}{l}16 \ldots \ldots \ldots \\
17 \ldots \ldots \ldots \\
18 \ldots \ldots \ldots \ldots \\
19 \ldots \ldots \ldots \ldots \ldots \\
20 \ldots \ldots \ldots \ldots \ldots\end{array}$ & $\begin{array}{l}3.6 \\
3.5 \\
3.35 \\
3.0 \\
2.7\end{array}$ & $\begin{array}{l}3.25 \\
3.25 \\
3.20 \\
3.35 \\
3.4\end{array}$ & $\begin{array}{l}3.0 \\
2.95 \\
2.9 \\
3.0 \\
2.95\end{array}$ & $\begin{array}{l}11.05 \\
11.4 \\
11.7 \\
13.1 \\
13.7\end{array}$ & $\begin{array}{l}6.5 \\
6.3 \\
6.7 \\
6.2 \\
5.3\end{array}$ & $\begin{array}{l}4.6 \\
2.9 \\
2.4 \\
2.3 \\
3.3\end{array}$ & $\begin{array}{l}4.3 \\
4.1 \\
3.8 \\
3.6 \\
4.2\end{array}$ & $\begin{array}{l}2.6 \\
4.1 \\
3.8 \\
3.1 \\
2.9\end{array}$ & $\begin{array}{l}3.9 \\
3.7 \\
3.4 \\
3.1 \\
2.9\end{array}$ & $\begin{array}{l}3.25 \\
4.05 \\
4.15 \\
5.0 \\
\text { (a) }\end{array}$ \\
\hline $\begin{array}{l}21 \ldots \ldots \ldots \\
22 \ldots \ldots \ldots \\
23 \ldots \ldots \ldots \\
24 \ldots \ldots \ldots \\
25 \ldots \ldots \ldots\end{array}$ & $\begin{array}{l}2.7 \\
2.8 \\
2.75 \\
2.8 \\
3.2\end{array}$ & $\begin{array}{l}3.3 \\
3.3 \\
3.25 \\
3.25 \\
3.20\end{array}$ & $\begin{array}{l}2.95 \\
3.05 \\
3.05 \\
2.95 \\
2.9\end{array}$ & $\begin{array}{l}14.3 \\
14.1 \\
13.2 \\
12.15 \\
11.9\end{array}$ & $\begin{array}{l}\text { 5. } 15 \\
4.35 \\
2.3 \\
4.5 \\
4.7\end{array}$ & $\begin{array}{l}4.8 \\
4.75 \\
4.3 \\
4.2 \\
3.0\end{array}$ & $\begin{array}{l}3.9 \\
3.4 \\
4.2 \\
3.9 \\
3.8\end{array}$ & $\begin{array}{l}2.6 \\
2.85 \\
3.2 \\
3.6 \\
3.9\end{array}$ & $\begin{array}{l}2.75 \\
3.0 \\
2.9 \\
2.8 \\
2.7\end{array}$ & $\mid \begin{array}{l}\ldots \ldots \\
\ldots \ldots \\
\cdots \ldots \\
\cdots \ldots \\
\cdots \ldots\end{array}$ \\
\hline $\begin{array}{l}26 \ldots \ldots \\
27 \ldots \ldots \\
28 \ldots \\
29 \ldots \ldots \\
30 \ldots \ldots \\
\$ 11 \ldots \ldots \ldots \\
\end{array}$ & $\begin{array}{l}4.15 \\
4.85 \\
5.3 \\
5.0 \\
4.8 \\
4.8\end{array}$ & $\begin{array}{c}3.25 \\
3.2 \\
3.05 \\
\ldots . . . \\
\cdots \cdots \\
\cdots\end{array}$ & $\begin{array}{l}3.05 \\
3.3 \\
3.4 \\
3.45 \\
3.55 \\
3.6\end{array}$ & $\begin{array}{r}10.7 \\
10.1 \\
9.6 \\
9.4 \\
9.2 \\
-9 .\end{array}$ & $\begin{array}{l}5.5 \\
7.0 \\
6.7 \\
7.7 \\
8.3 \\
8.9\end{array}$ & $\begin{array}{l}2.6 \\
8.35 \\
9.0 \\
8.8 \\
9.1\end{array}$ & $\begin{array}{l}3.2 \\
3.8 \\
3.6 \\
3.4 \\
3.0 \\
2.8\end{array}$ & $\begin{array}{l}4.1 \\
3.8 \\
3.6 \\
3.5 \\
3.25 \\
2.8\end{array}$ & $\begin{array}{l}2.65 \\
2.8 \\
2.75 \\
2.7 \\
2.8\end{array}$ & 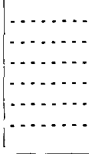 \\
\hline
\end{tabular}

$a$ Gage reader left.

Rating table for Menominee River near Iron Mountain, Mich., for 1906.

\begin{tabular}{|c|r|r|r|r|r|r|r|}
\hline $\begin{array}{c}\text { Gage } \\
\text { height. }\end{array}$ & $\begin{array}{c}\text { Dis- } \\
\text { charge. }\end{array}$ & $\begin{array}{r}\text { Gage } \\
\text { height. }\end{array}$ & $\begin{array}{c}\text { Dis- } \\
\text { charge. }\end{array}$ & $\begin{array}{c}\text { Gage } \\
\text { height. }\end{array}$ & $\begin{array}{c}\text { Dis- } \\
\text { charge. }\end{array}$ & $\begin{array}{r}\text { Gage } \\
\text { height. }\end{array}$ & $\begin{array}{c}\text { Dis- } \\
\text { charge. }\end{array}$ \\
\hline Feet. & Sec.-ft. & Feet. & Sec.-ft. & Feet. & Sec.-ft. & Feet. & Sec.-ft. \\
2.00 & 1,540 & 3.30 & 2,432 & 4.60 & 3,396 & 6.80 & 5,230 \\
2.10 & 1,606 & 3.40 & 2,503 & 4.70 & 3,474 & 7.00 & 5,420 \\
2.20 & 1,672 & 3.50 & 2,575 & 4.80 & 3,552 & 7.20 & 5,615 \\
2.30 & 1,739 & 3.60 & 2,647 & 4.90 & 3,630 & 7.40 & 5,815 \\
2.40 & 1,806 & 3.70 & 2,719 & 5.00 & 3.708 & 7.60 & 6,025 \\
2.50 & 1,874 & 3.80 & 2,792 & 5.20 & 3,865 & 7.80 & 6,235 \\
2.60 & 1,942 & 3.90 & 2,866 & 5.40 & 4,023 & 8.00 & 6,450 \\
2.70 & 2,011 & 4.00 & 2,940 & 5.60 & 4,183 & 9.00 & 7,630 \\
2.80 & 2,080 & 4.10 & 3,015 & 5.80 & 4,345 & 10.00 & 8,930 \\
2.90 & 2,150 & 4.20 & 3,090 & 6.00 & 4,510 & 11.00 & 10,250 \\
3.00 & 2,220 & 4.30 & 3,166 & 6.20 & 4,680 & 12.00 & 11,660 \\
3.10 & 2,290 & 4.40 & 3,242 & 6.40 & 4,860 & 13.00 & 13,100 \\
3.20 & 2,361 & 4.50 & 3,319 & 6.60 & 5,040 & 14.00 & 14,600 \\
& & & & & & \\
\hline
\end{tabular}

Note.-The above table is applicable only for open-channel conditions. It is based on discharge measurements made during 1902-1906, and is fairly well defined. 
Monthly discharge of Menominee River near Iron Mountain, Mich., for 1906.

[Drainage area, 2,420 square miles.]

\begin{tabular}{|c|c|c|c|c|c|}
\hline \multirow[b]{2}{*}{ Month. } & \multicolumn{3}{|c|}{ Discharge in second-feet. } & \multicolumn{2}{|c|}{ Run-off. } \\
\hline & Maximum. & Minimum. & Mean. & $\begin{array}{l}\text { Sec.-ft. per } \\
\text { sq. mile. }\end{array}$ & $\begin{array}{l}\text { Depth in } \\
\text { inches. }\end{array}$ \\
\hline 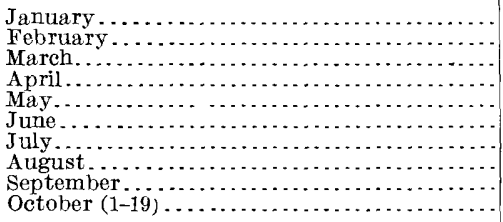 & $\begin{array}{r}3,940 \\
3,360 \\
2,650 \\
15,100 \\
8,670 \\
10,700 \\
7,890 \\
3,130 \\
2,940 \\
3,710\end{array}$ & $\begin{array}{l}1,740 \\
2,260 \\
2,080 \\
2,790 \\
1,740 \\
1,740 \\
2,080 \\
1,810 \\
1,540 \\
1,710\end{array}$ & $\begin{array}{l}2,370 \\
2,590 \\
2,250 \\
8,040 \\
5,610 \\
5,040 \\
3,500 \\
2,400 \\
2,160 \\
2,140\end{array}$ & $\begin{array}{c}0.979 \\
1.07 \\
.930 \\
3.32 \\
2.32 \\
2.08 \\
1.45 \\
.992 \\
.893 \\
.884\end{array}$ & $\begin{array}{r}1.13 \\
1.11 \\
1.07 \\
3.70 \\
2.68 \\
2.32 \\
1.67 \\
1.14 \\
1.00 \\
.62\end{array}$ \\
\hline
\end{tabular}

Nore.-Values are rated as follows: January and March to October, fair. It is probable that ice conditions affected the flow during February and that the value given above is considerably in excess of the true value.

\section{PESHTIGO RIVER BASIN.}

\section{DESCRIPTION OF BASIN.}

Peshtigo River rises in the plateau region of northwestern Wisconsin at an elevation of about 1,600 feet and descends on an average about 10 feet to the mile. But few of its powers have been developed on account of this region being thinly settled. There are falls of 46 feet, 35 feet, and 25 feet at different places on the river that could easily be developed. (See Pl. III.)

\section{PESHTIGO RIVER SURVEY.}

In order to point out the power possibilities along Peshtigo River, a survey was made during 1906 from the mouth to Rat River. From the data collected on this survey sheets have been prepared showing a profile of the water surface, a plan of the river, contour along the bank, and prominent natural or artificial features.

The results of this survey have been published on separate sheets and may be had upon application to the Director of the Geological Survey.

\section{PESHTIGO RIVER AT CRIVITZ, WIS.}

This station was established April 20 and was discontinued December 12,1906 . It was located on the railroad bridge about one-fourth mile south of Crivitz post-office (or Ellis Junction railroad station).

The channel is straight for about 1,000 feet above and 300 feet below the station. Both banks are of medium height and do not overflow; all the water passes the section, being confined by the railroad embankments. The bed of the stream is gravel and is permanent. There is but one channel at all stages. The current is medium. Log jams and sunken logs affect the discharge at times. 


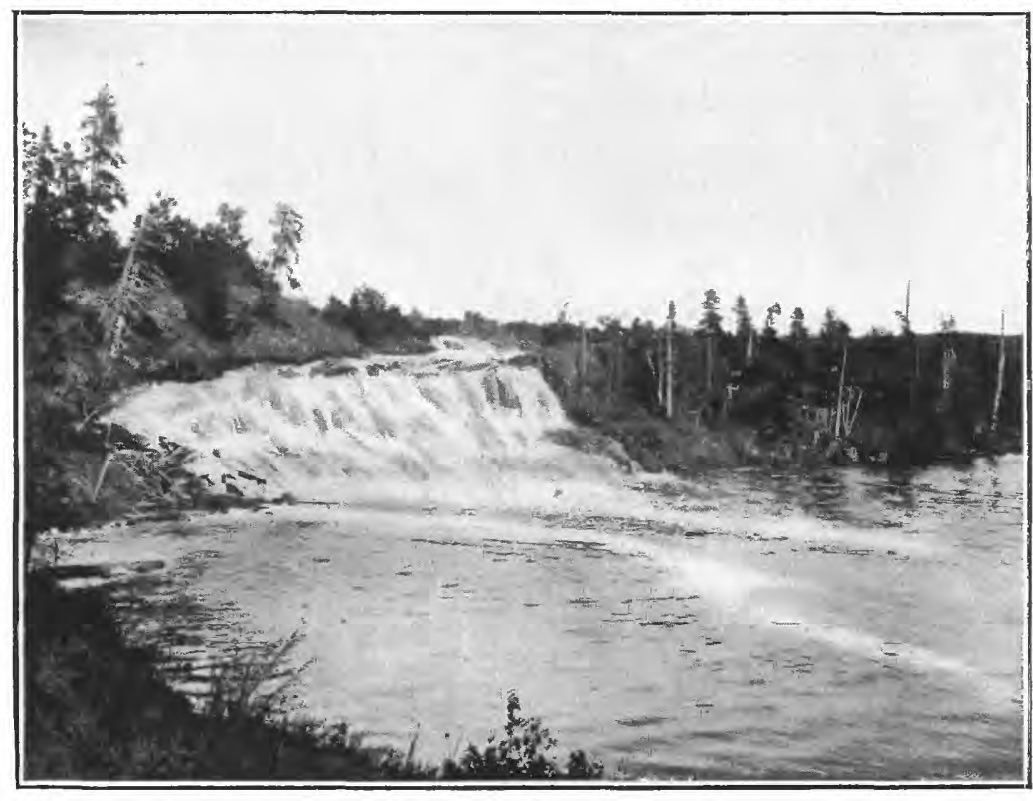

A

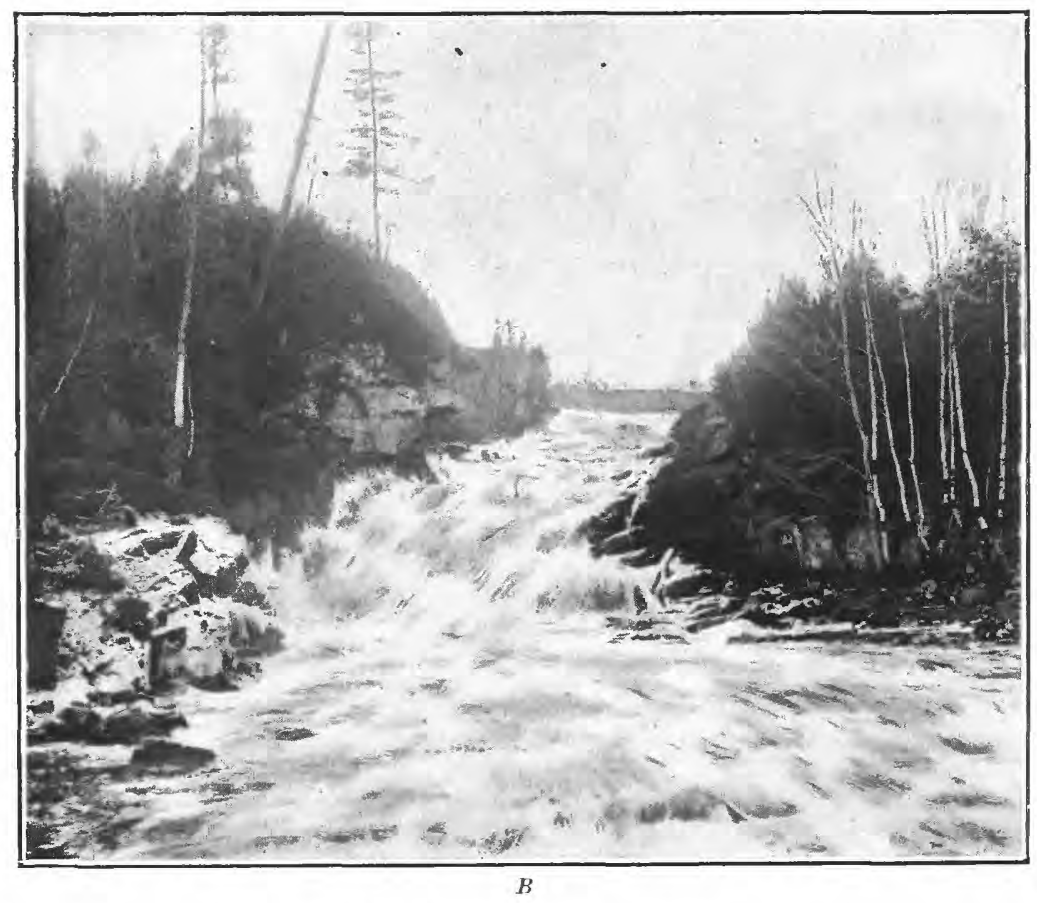

FALLS ON PESHTIGO RIVER, WISCONSIN.

$A$, High Falls (40-foot fall); $B$, Caldron Falls (55-foot fall). 
Discharge measurements are made from the upstream side of the bridge, to which the gage is attached.

A standard chain gage, attached to the upstream side of the bridge, was read during 1906 by Andrew Johnson; length of chain, 22.85 feet. The bench mark is the top of parapet wall of left abutment, extreme downstream end, near front face, marked with white paint; elevation, 21.52 feet. The reference point is the center of gage pulley; elevation, 22.66 feet. Elevations refer to the datum of the gage.

Discharge measurements of Peshtigo River at Crivitz, Wis., in 1906.

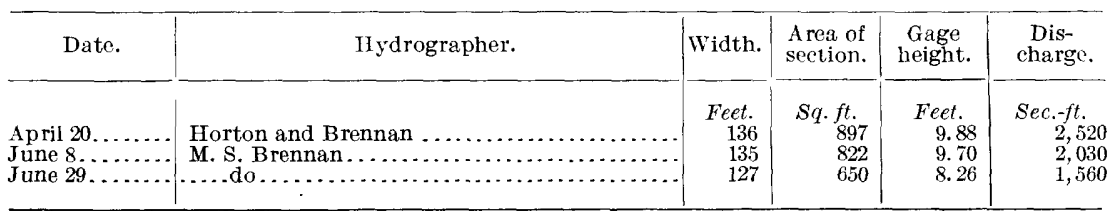

Daily gage height, in feet, of Peshtigo River at Crivitz, Wis., for 1906.

\begin{tabular}{|c|c|c|c|c|c|c|c|c|c|}
\hline Day. & Apr. & May. & June. & July. & Aug. & Sept. & Oct. & Nov. & Dec. \\
\hline . & & $\begin{array}{l}8.9 \\
8.4 \\
9.5 \\
7.2 \\
7.9\end{array}$ & $\begin{array}{l}7.9 \\
6.8 \\
6.7 \\
6.4 \\
6.7\end{array}$ & $\begin{array}{l}6.2 \\
6.0 \\
6.1 \\
6.0 \\
8.5\end{array}$ & $\begin{array}{l}4.3 \\
5.6 \\
5.0 \\
4.3 \\
5.3\end{array}$ & $\begin{array}{l}5.7 \\
6.1 \\
5.5 \\
6.6 \\
6.6\end{array}$ & $\begin{array}{l}5.7 \\
5.4 \\
5.2 \\
4.0 \\
5.4\end{array}$ & $\begin{array}{l}6.7 \\
6.3 \\
6.7 \\
6.2 \\
5.7\end{array}$ & $\begin{array}{l}6.9 \\
7.0 \\
7.4 \\
6.5 \\
6.2\end{array}$ \\
\hline 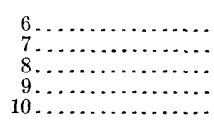 & & $\begin{array}{l}8.4 \\
6.6 \\
7.3 \\
8.2 \\
6.4\end{array}$ & $\begin{array}{l}7.9 \\
8.5 \\
8.4 \\
9.7 \\
9.8\end{array}$ & $\begin{array}{l}7.1 \\
6.8 \\
6.6 \\
6.8 \\
6.5\end{array}$ & $\begin{array}{l}5.8 \\
5.8 \\
6.1 \\
5.9 \\
5.8\end{array}$ & $\begin{array}{l}6.2 \\
6.2 \\
5.6 \\
5.6 \\
4.0\end{array}$ & $\begin{array}{l}5.3 \\
5.4 \\
5.4 \\
5.2 \\
5.7\end{array}$ & $\begin{array}{l}5.9 \\
5.9 \\
5.9 \\
5.8 \\
5.7\end{array}$ & $\begin{array}{l}6.3 \\
6.5 \\
6.2 \\
6.0 \\
6.1\end{array}$ \\
\hline 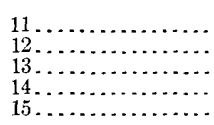 & & $\begin{array}{l}7.1 \\
5.9 \\
6.7 \\
6.5 \\
7.7\end{array}$ & $\begin{array}{l}7.4 \\
6.9 \\
7.7 \\
7.3 \\
8.4\end{array}$ & $\begin{array}{l}6.1 \\
6.6 \\
6.2 \\
6.0 \\
6.6\end{array}$ & $\begin{array}{l}5.7 \\
5.9 \\
5.5 \\
6.4 \\
5.0\end{array}$ & $\begin{array}{l}5.5 \\
5.8 \\
5.7 \\
5.7 \\
5.4\end{array}$ & $\begin{array}{l}5.3 \\
5.4 \\
5.6 \\
5.4 \\
5.6\end{array}$ & 5.9 & 5.8 \\
\hline $20 \ldots$ & 9.8 & $\begin{array}{l}6.5 \\
6.5 \\
6.0 \\
6.7 \\
6.2\end{array}$ & $\begin{array}{l}8.3 \\
6.2 \\
6.1 \\
6.3 \\
7.5\end{array}$ & $\begin{array}{l}6.5 \\
6.8 \\
6.4 \\
6.5 \\
6.1\end{array}$ & $\begin{array}{l}5.5 \\
5.2 \\
5.3 \\
5.3 \\
5.6\end{array}$ & 5.5 & $\begin{array}{l}5.3 \\
5.4 \\
5.3\end{array}$ & 5.9 & \\
\hline $20 \ldots \ldots \ldots$ & $\begin{array}{r}10.4 \\
10.7 \\
10.6 \\
10.5 \\
9.9\end{array}$ & $\begin{array}{l}6.5 \\
6.7 \\
6.6 \\
6.5 \\
7.1\end{array}$ & $\begin{array}{l}7.5 \\
8.5 \\
8.4 \\
8.5 \\
8.5\end{array}$ & $\begin{array}{l}6.6 \\
6.5 \\
5.8 \\
5.3 \\
5.4\end{array}$ & $\begin{array}{l}5.3 \\
5.7 \\
5.6 \\
5.4 \\
6.2\end{array}$ & & 6.8 & 5.8 & \\
\hline 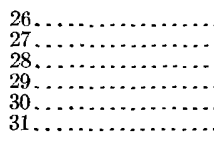 & $\begin{array}{l}9.3 \\
8.5 \\
8.6 \\
8.5 \\
8.1\end{array}$ & $\begin{array}{l}6.6 \\
8.4 \\
8.7 \\
7.4 \\
7.7 \\
7.9\end{array}$ & $\begin{array}{l}6.9 \\
7.0\end{array}$ & $\begin{array}{l}5.7 \\
5.7 \\
5.7 \\
5.8 \\
5.6 \\
5.3\end{array}$ & $\begin{array}{l}5.2 \\
6.1 \\
6.0 \\
6.8 \\
6.1 \\
6.0\end{array}$ & 5.7 & $\begin{array}{l}6.9 \\
7.5 \\
7.3 \\
7.2 \\
6.8 \\
6.7\end{array}$ & $\begin{array}{l}0.8 \\
6.9\end{array}$ & \\
\hline
\end{tabular}

PESHTIGO RIVER AT HERMAN'S FARM, NEAR CRIVITZ, WIS.

This station was established September 7, 1906, under the direction of D. W. Mead. It is located at Herman's farm, $4 \frac{1}{2}$ miles west of Crivitz, Wis., in the northwest quarter of sec. 26, T. 32 N., R. 19 E.

The channel is straight for about 800 feet above the station and for 300 feet below. The banks do not overflow. The bottom of the 
river is gravel and permanent. There is one channel at all stages. The current is swift.

Discharge measurements are made from a boat which is held in position by means of a rope stretched across the river.

The gage, which is read daily by Rose Herman, consists of two sections. The bench mark is a copper nail in top of a pine stump 50 feet from the water's edge and about 50 feet southeast of the gage; elevation, 731.70 feet above sea level and 19.82 feet above the datum of the gage.

Discharge measurements of Peshtıgo River at Herman's farm, near Crivitz, Wis., in 1906.

\begin{tabular}{|c|c|c|c|c|c|}
\hline Date. & Hydrographer. & Width. & $\begin{array}{l}\text { Area of } \\
\text { section. }\end{array}$ & $\begin{array}{c}\text { Gage } \\
\text { height. }\end{array}$ & Discharge. \\
\hline $\begin{array}{l}\text { September } 7 \ldots \\
\text { October } 29 . \ldots \\
\text { November } 16 \ldots\end{array}$ & 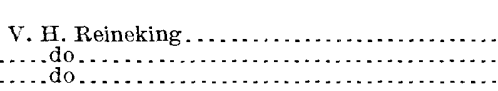 & $\begin{array}{r}\text { Feet. } \\
128 \\
130 \\
125\end{array}$ & $\begin{array}{r}S q . f t . \\
436 \\
463 \\
380\end{array}$ & $\begin{array}{l}\text { Feet. } \\
3.40 \\
4.20 \\
3.20\end{array}$ & $\begin{array}{r}\text { Sec. } f t . \\
657 \\
1,020 \\
562\end{array}$ \\
\hline
\end{tabular}

Daily gage height, in feet, of Peshtigo River at Herman's farm, near Crivitz, Wis., for 1906.

\begin{tabular}{|c|c|c|c|c|c|c|c|c|c|}
\hline Day. & Sept. & Oct. & Nov. & Dec. & Day. & Sept. & Oct. & Nov. & Dec. \\
\hline 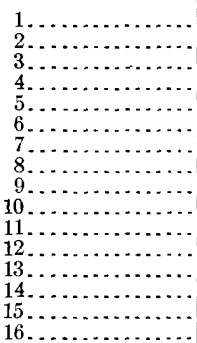 & $\begin{array}{l}3.4 \\
3.2 \\
3.0 \\
3.0 \\
3.0 \\
3.15 \\
3.2 \\
3.1 \\
3.1 \\
3.3\end{array}$ & $\begin{array}{l}3.0 \\
2.95 \\
2.3 \\
3.25 \\
3.0 \\
3.0 \\
2.95 \\
3.0 \\
3.0 \\
3.05 \\
2.8 \\
3.2 \\
3.05 \\
3.0 \\
3.0 \\
3.0\end{array}$ & $\begin{array}{l}3.7 \\
3.75 \\
3.5 \\
3.4 \\
3.4 \\
3.35 \\
3.35 \\
3.4 \\
3.4 \\
3.5 \\
3.5 \\
3.45 \\
3.4 \\
3.3 \\
3.25 \\
3.2\end{array}$ & $\begin{array}{l}4.2 \\
4.0 \\
3.9 \\
3.9 \\
3.8 \\
3.6 \\
3.6 \\
3.5 \\
3.6 \\
3.55 \\
3.5 \\
3.3 \\
3.35 \\
3.3 \\
3.3 \\
3.3\end{array}$ & 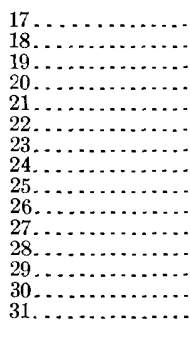 & \begin{tabular}{|l|}
3.4 \\
3.45 \\
3.5 \\
3.4 \\
3.4 \\
3.4 \\
3.45 \\
3.4 \\
3.4 \\
3.4 \\
3.0 \\
3.7 \\
3.35 \\
3.15 \\
$\ldots \ldots .$.
\end{tabular} & $\begin{array}{l}3.0 \\
3.05 \\
3.3 \\
3.5 \\
3.7 \\
3.8 \\
3.8 \\
3.9 \\
4.0 \\
4.1 \\
4.2 \\
4.15 \\
4.2 \\
4.0 \\
3.9\end{array}$ & \begin{tabular}{|l|}
3.4 \\
3.5 \\
3.5 \\
3.45 \\
3.5 \\
3.3 \\
3.3 \\
3.35 \\
3.4 \\
3.8 \\
4.0 \\
4.2 \\
4.3 \\
4.25 \\
$\ldots . .$.
\end{tabular} & $\begin{array}{l}3.3 \\
3.3 \\
3.35 \\
3.4 \\
3.2 \\
3.2 \\
3.25 \\
3.15 \\
3.1 \\
3.1 \\
3.05 \\
3.15 \\
3.1 \\
3.05 \\
3.1\end{array}$ \\
\hline
\end{tabular}

Rating table for Peshtigo River at Herman's farm, near Crivitz, Wis., for 1906.

\begin{tabular}{|c|c|c|c|c|c|c|c|}
\hline $\begin{array}{l}\text { Gage } \\
\text { height. }\end{array}$ & $\begin{array}{c}\text { Dis- } \\
\text { charge. }\end{array}$ & $\begin{array}{c}\text { Gage } \\
\text { height. }\end{array}$ & $\begin{array}{c}\text { Dis- } \\
\text { charge. }\end{array}$ & $\begin{array}{c}\text { Gage } \\
\text { height. }\end{array}$ & $\begin{array}{c}\text { Dis- } \\
\text { charge. }\end{array}$ & $\begin{array}{r}\text { Gage } \\
\text { hoight. }\end{array}$ & $\begin{array}{l}\text { Dis- } \\
\text { charge. }\end{array}$ \\
\hline $\begin{array}{l}\text { Feet. } \\
2.30 \\
2.40 \\
2.50 \\
2.60 \\
2.70 \\
2.80\end{array}$ & $\begin{array}{r}\text { Sec.-ft. } \\
280 \\
305 \\
330 \\
360 \\
390 \\
420\end{array}$ & $\begin{array}{l}\text { Feet. } \\
2.90 \\
3.00 \\
3.10 \\
3.20 \\
3.30\end{array}$ & $\begin{array}{r}\text { Sec.-ft } \\
455 \\
490 \\
525 \\
565 \\
605\end{array}$ & $\begin{array}{c}\text { Feet. } \\
3.40 \\
3.50 \\
3.60 \\
3.70 \\
3.80\end{array}$ & $\begin{array}{r}\text { Sec. }-f t \text {. } \\
645 \\
690 \\
735 \\
780 \\
825\end{array}$ & $\begin{array}{r}\text { Feet. } \\
3.90 \\
4.00 \\
4.10 \\
4.20 \\
4.30\end{array}$ & $\begin{array}{r}\text { Sec.-ft. } \\
870 \\
920 \\
970 \\
1,020 \\
1,070\end{array}$ \\
\hline
\end{tabular}

Note.- The above table is applicable only for open-channel conditions. It is based on three discharge measurements made during 1906, and is well defined between gage heights 3.2 feet and 4.2 feet.

Monthly discharge of Peshtigo River at Herman's farm, near Crivitz, Wis., for 1906.

\begin{tabular}{|c|c|c|c|}
\hline \multirow{2}{*}{ Month. } & \multicolumn{3}{|c|}{ Discharge in second-feet. } \\
\hline & Maximum. & Minimum. & Mean. \\
\hline 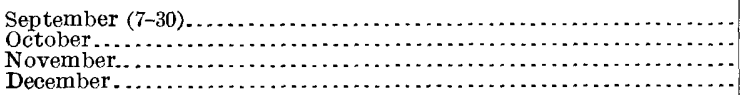 & $\begin{array}{r}780 \\
1,020 \\
1,070 \\
1,020\end{array}$ & $\begin{array}{l}490 \\
280 \\
565 \\
508\end{array}$ & $\begin{array}{l}601 \\
646 \\
710 \\
653\end{array}$ \\
\hline
\end{tabular}

Note.-Values for 1906 are good. 


\section{OCON'TO RIVER BASIN.}

\section{DESCRIPTION OF BASIN.}

Oconto River rises in a number of small lakes and swamps in the plateau region at an elevation of about 1,530 feet above sea level and descends 945 feet in its length of 87 miles. About two-thirds of its total fall is in the upper 35 miles of its course. At Undershell it turns abruptly and flows nearly due east, joining Lake Michigan near Oconto. The most important water powers are found in the last 33 miles of its course, in which distance the river descends 190 feet.

OCONTO RIVER AT GILLETT, WIS.

This station was established June 7, 1906. It is located at the highway bridge about $2 \frac{1}{2}$ miles south of Gillett, Wis.

The channel is straight for about 200 feet above and 300 feet below the station. Both banks are low but do not overflow. The bed of the stream is gravel and is permanent. The current is swift. Old pier foundations at both banks may affect the flow somewhat.

A standard chain gage, which was read during 1906 by Samuel Gilbertson and Hattie Gilbertson, is fastened to the lower side of the bridge; length of chain, 24.82 feet. The reference point is the top of downstream board guard rail 59 feet from the initial point; elevation, 17.75 feet above gage datum.

Discharge measurements of Oconto River at Gillett, Wis., in 1906.

\begin{tabular}{|c|c|c|c|c|c|}
\hline Date. & Hydrographer. & Width. & $\begin{array}{l}\text { Area of } \\
\text { section. }\end{array}$ & $\begin{array}{c}\text { Gage } \\
\text { height. }\end{array}$ & $\begin{array}{c}\text { Dis- } \\
\text { charge. }\end{array}$ \\
\hline $\begin{array}{l}\text { June } 7 \ldots \\
\text { June } 29 .\end{array}$ & $\begin{array}{l}\text { M. S. Brennan } . \\
\text {....do.......... }\end{array}$ & $\begin{array}{r}\text { Feet. } \\
81 \\
77\end{array}$ & $\begin{array}{r}S q . f t . \\
359 \\
339\end{array}$ & $\begin{array}{r}\text { Feet. } \\
5.95 \\
5.72\end{array}$ & $\begin{array}{r}\text { Sec.-ft. } \\
926 \\
727\end{array}$ \\
\hline
\end{tabular}

Daily gage height, in feet, of Oconto River at Gillett, Wis., for 1906.

\begin{tabular}{|c|c|c|c|c|c|c|c|}
\hline Day. & June. & July. & Aug. & Sept. & Oct. & Nov. & Dec. \\
\hline 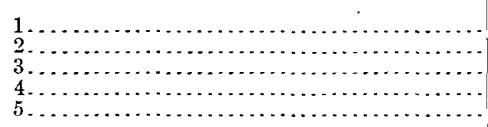 & $\cdots$ & $\begin{array}{l}5.4 \\
5.5 \\
5.7 \\
6.15 \\
5.75\end{array}$ & $\begin{array}{l}4.75 \\
4.7 \\
4.75 \\
4.75 \\
4.2\end{array}$ & $\begin{array}{l}5.15 \\
5.15 \\
5.7 \\
5.7 \\
5.5\end{array}$ & $\begin{array}{l}5.1 \\
5.4 \\
5.2 \\
5.2 \\
4.9\end{array}$ & $\begin{array}{l}6.05 \\
6.0 \\
5.9 \\
5.8 \\
5.8\end{array}$ & $\begin{array}{l}6.7 \\
6.7 \\
6.6 \\
6.15 \\
6.95\end{array}$ \\
\hline 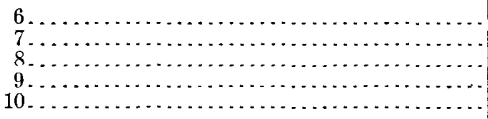 & $\begin{array}{l}-5.95 \\
6.0 \\
6.15 \\
6.1\end{array}$ & $\begin{array}{l}6.0 \\
6.0 \\
5.8 \\
5.75 \\
5.6\end{array}$ & $\begin{array}{l}4.25 \\
4.85 \\
4.9 \\
4.8 \\
5.1\end{array}$ & $\begin{array}{l}5.6 \\
5.6 \\
5.0 \\
5.2 \\
5.25\end{array}$ & $\begin{array}{l}5.1 \\
5.4 \\
5.4 \\
5.1 \\
5.2\end{array}$ & $\begin{array}{l}5.85 \\
5.7 \\
5.8 \\
5.8 \\
5.7\end{array}$ & $\begin{array}{l}5.6 \\
6.1 \\
7.25 \\
7.5 \\
7.85\end{array}$ \\
\hline $\begin{array}{r}11 \\
12 \\
13 \\
14 \\
14 \\
15\end{array}$ & $\begin{array}{l}5.95 \\
5.9 \\
6.2 \\
6.15 \\
5.6\end{array}$ & $\begin{array}{l}5.6 \\
5.6 \\
5.5 \\
5.1 \\
5.2\end{array}$ & $\begin{array}{l}5.4 \\
5.7 \\
5.3 \\
5.3 \\
5.3\end{array}$ & $\begin{array}{l}5.3 \\
5.25 \\
5.2 \\
5.65 \\
4.9\end{array}$ & $\begin{array}{l}5.0 \\
5.3 \\
6.15 \\
4.3 \\
5.35\end{array}$ & $\begin{array}{l}4.6 \\
5.7 \\
5.4 \\
5.7 \\
5.5\end{array}$ & $\begin{array}{l}8.3 \\
9.1 \\
7.8 \\
7.4 \\
7.35\end{array}$ \\
\hline
\end{tabular}


Daily gage height, in feet, of Oconto River at Gillett, Wis., for 1906-Continued.

\begin{tabular}{|c|c|c|c|c|c|c|c|}
\hline Day. & June. & July. & Aug. & Sept. & Oct. & Nov. & Dec. \\
\hline $\begin{array}{l}16 \\
17 \\
18 \\
19 \\
19 \\
20\end{array}$ & $\begin{array}{l}5.65 \\
5.6 \\
5.6 \\
5.0 \\
5.4\end{array}$ & $\begin{array}{l}5.2 \\
5.8 \\
5.0 \\
4.95 \\
5.0\end{array}$ & $\begin{array}{l}5.4 \\
5.3 \\
4.8 \\
4.5 \\
5.2\end{array}$ & $\begin{array}{l}6.15 \\
5.8 \\
5.8 \\
5.9 \\
6.0\end{array}$ & $\begin{array}{l}5.3 \\
5.3 \\
5.3 \\
5.8 \\
6.0\end{array}$ & $\begin{array}{l}5.5 \\
5.95 \\
5.9 \\
6.2 \\
6.2\end{array}$ & $\begin{array}{l}6.8 \\
7.7 \\
8.1 \\
9.0 \\
9.1\end{array}$ \\
\hline $\begin{array}{l}21 \ldots \ldots \\
22 \\
23 \ldots \ldots \\
24 \\
25 \ldots\end{array}$ & $\begin{array}{l}5.7 \\
6.0 \\
6.0 \\
6.2 \\
5.85\end{array}$ & $\begin{array}{l}5.0 \\
5.5 \\
5.0 \\
4.9 \\
4.85\end{array}$ & $\begin{array}{l}5.2 \\
5.2 \\
5.9 \\
5.6 \\
5.8\end{array}$ & $\begin{array}{l}6.0 \\
5.1 \\
5.3 \\
5.5 \\
5.5\end{array}$ & $\begin{array}{l}6.1 \\
6.0 \\
6.2 \\
6.15 \\
5.9\end{array}$ & $\begin{array}{l}6.35 \\
6.3 \\
6.25 \\
6.15 \\
5.7\end{array}$ & 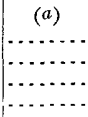 \\
\hline 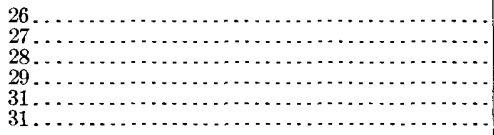 & $\begin{array}{r}5.75 \\
5.65 \\
5.75 \\
5.75 \\
5.65 \\
.\end{array}$ & $\begin{array}{l}4.8 \\
4.75 \\
4.75 \\
4.4 \\
4.7 \\
4.7\end{array}$ & $\begin{array}{l}6.0 \\
6.3 \\
6.2 \\
6.1 \\
5.9 \\
5.6\end{array}$ & $\begin{array}{l}5.5 \\
5.5 \\
5.4 \\
5.05 \\
5.0 \\
\ldots . .\end{array}$ & $\begin{array}{l}6.1 \\
6.4 \\
6.4 \\
6.7 \\
6.3 \\
6.1\end{array}$ & $\begin{array}{l}7.05 \\
7.3 \\
7.35 \\
7.3 \\
7.2 \\
7 . .\end{array}$ & $\mid \begin{array}{l}\cdots \ldots \\
\cdots \ldots \\
\cdots \cdots \\
\cdots \cdots\end{array}$ \\
\hline
\end{tabular}

aFrozen.

OCONTO RIVER AT STILES, WIS.

This station was established April 20, 1906, but was discontinued June 6, 1906, as the dam immediately above the station seriously modified the flow.

Discharge measurements of Oconto River at Stiles, Wis., in 1906.

\begin{tabular}{|c|c|c|c|c|c|}
\hline Date. & Hydrographer. & Width. & $\begin{array}{l}\text { Area of } \\
\text { section. }\end{array}$ & $\begin{array}{c}\text { Gage } \\
\text { height. }\end{array}$ & $\begin{array}{l}\text { Dis- } \\
\text { charge. }\end{array}$ \\
\hline $\begin{array}{l}\text { April } 20 \ldots \ldots \ldots \\
\text { June } 6 \ldots \ldots \ldots\end{array}$ & $\begin{array}{l}\text { Horton and Brennan . . . . } \\
\text { M. S. Brennan ............ }\end{array}$ & $\begin{array}{r}\text { Feet. } \\
119 \\
120\end{array}$ & $S q \cdot f t$. & $\begin{array}{l}\text { Fieet. } \\
4.74 \\
2.71\end{array}$ & $\begin{array}{r}\text { Sec.-ft. } \\
2,510 \\
988\end{array}$ \\
\hline
\end{tabular}

Daily gage height, in feet, of Oconto River at Stiles, Wis., for 1906.

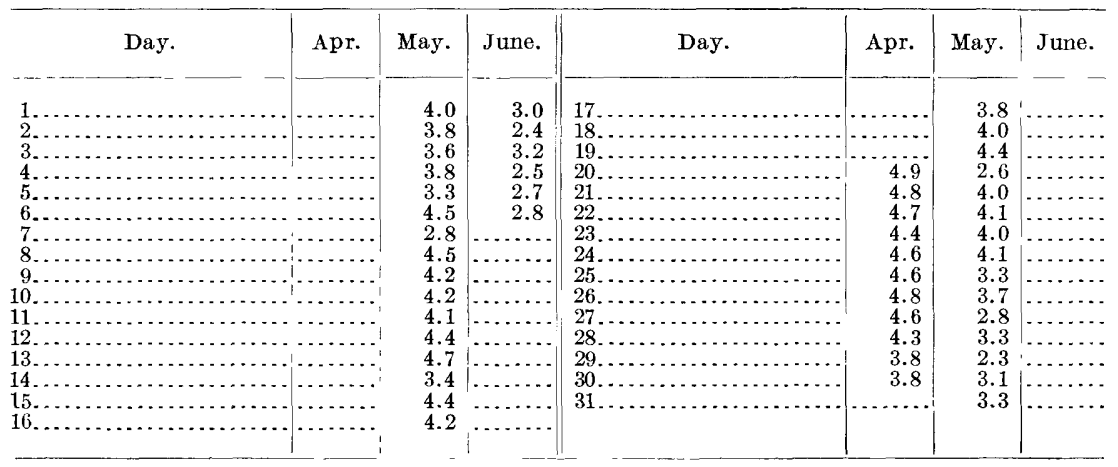

WOLF RIVER BASIN.

DESCRIPTION OF BASIN.

Wolf River rises in a number of small lakes 25 miles south of the northern boundary of Wisconsin and flows in a general southerly direction, entering upper Fox River at a point about 10 miles west 
of Lake Winnebago. In the upper haif of its course the descent of Wolf River is very rapid. At the Chicago and Northwestern Railroad crossing near Lenox it has an elevation of 1,562 feet above sea level, and between this point and Shawano, 80 miles, the river falls practically 10 feet per mile. Shawano is the head of navigation; below this point the river is very sluggish, with no opportunities for water power.

\section{WOLF RIVER AT DARROW'S BRIDGE, NEAR SHAWANO, WIS.}

A station was established April 21, 1906, at Darrow's bridge, about 2 miles south of Shawano, and was discontinued June 6, 1906, as the dam above modified the flow.

A measurement was made April 21, 1906, by Horton and Brennan, with the following results:

Width, 188 feet; area, 1,350 square feet; gage height, 5.87 feet; discharge, 3,890 second-feet.

Daily gage height, in feet, of Wolf River at Darrow's bridge, near Shawano, Wis., for 1906.

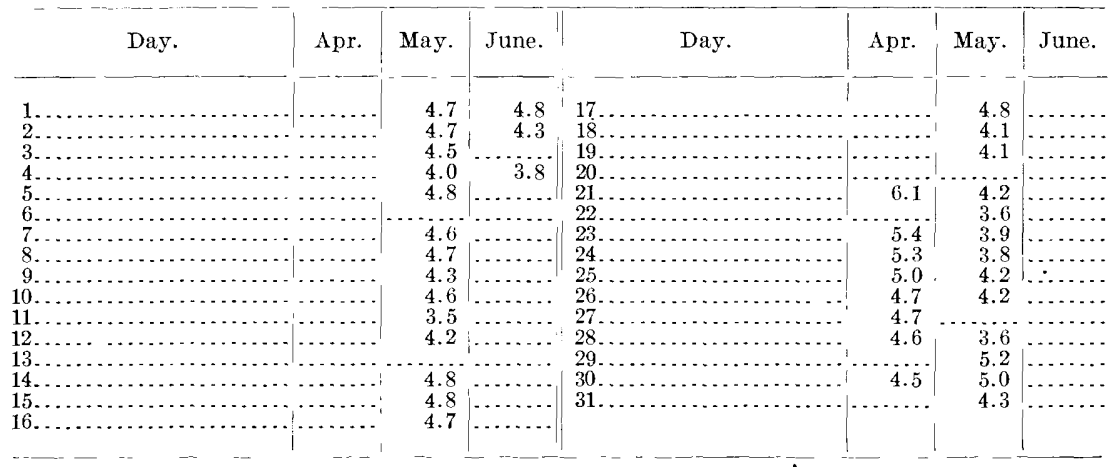

WOLF RIVER AT WHITE HOUSE BRIDGE, NEAR SHAWANO, WIS.

This station was established June 6,.1906. It is located at the "White House" highway bridge, about $3 \frac{1}{2}$ miles north of Shawano, Wis.

The channel is straight for about 200 feet above and 500 feet below the station. Both banks are of medium height and do not overflow. The bed of the stream is gravel and is permanent. There is one channel at all stages. The current is medium swift. This station may be affected by back water from the dam about 4 miles below.

A standard chain gage, which is read daily by Albert Utke, is fastened to the guard rail on the upstream side of the bridge; length of chain, 16.35 feet. The reference point is the center of gage pulley; elevation, 16.07 feet above gage datum. 
Discharge measurements of Wolf River near Shawano, Wis., in 1906.

\begin{tabular}{|c|c|c|c|c|c|}
\hline Date. & Hydrographer. & Width. & $\begin{array}{l}\text { Area of } \\
\text { section. }\end{array}$ & $\begin{array}{l}\text { Gage } \\
\text { height. }\end{array}$ & $\begin{array}{c}\text { Dis- } \\
\text { charge. }\end{array}$ \\
\hline $\begin{array}{l}\text { June } 6 \ldots . \\
\text { June } 30 .\end{array}$ & $\begin{array}{c}\text { M. S. Brennan. } \\
\ldots . \text { do . . . . }\end{array}$ & $\begin{array}{r}\text { Feet. } \\
136 \\
132\end{array}$ & $\begin{array}{r}S q \cdot f t . \\
767 \\
629\end{array}$ & $\begin{array}{l}\text { Feet. } \\
6.90 \\
5.96\end{array}$ & $\begin{array}{r}S e c_{-}-f t . \\
1,970 \\
590\end{array}$ \\
\hline
\end{tabular}

Daily gage height, in feet, of Wolf River near Shawano, Wis., for 1906.

\begin{tabular}{|c|c|c|c|c|c|c|c|}
\hline Day. & June. & July. & Aug. & Sept. & Oct. & Nov. & Dec. \\
\hline $\begin{array}{l}1 \\
2 \\
2 \\
3 \\
4 \\
5\end{array}$ & 6.9 & $\begin{array}{l}-6.8 \\
8.2 \\
7.6 \\
7.6\end{array}$ & $\begin{array}{l}6.5 \\
6.3 \\
6.4 \\
6.2\end{array}$ & $\begin{array}{r}6.5 \\
6.5 \\
6.6 \\
6.4\end{array}$ & $\begin{array}{l}5.8 \\
5.8 \\
5.9 \\
6.0 \\
6.1\end{array}$ & $\begin{array}{c}6.8 \\
6.7 \\
6.6 \\
6.2\end{array}$ & $(a)^{7.7}$ \\
\hline $\begin{array}{r}6 \ldots \ldots \\
7 \ldots \ldots \ldots \\
8 \\
9 \\
90 \ldots \ldots\end{array}$ & $\begin{array}{l}7.4 \\
7.7 \\
7.9 \\
7.7 \\
7.7\end{array}$ & \begin{tabular}{r}
7.4 \\
7.3 \\
\hdashline 7.1 \\
6.4
\end{tabular} & $\begin{array}{l}6.2 \\
6.2 \\
6.0 \\
5.9 \\
6.0\end{array}$ & \begin{tabular}{l}
6.2 \\
6.1 \\
5.9 \\
\hdashline 6.0
\end{tabular} & $\begin{array}{l}6.0 \\
6.3 \\
6.1 \\
6.1\end{array}$ & $\begin{array}{l}6.4 \\
6.8 \\
6.5 \\
6.1 \\
6.4\end{array}$ & $\cdots$ \\
\hline $\begin{array}{l}11 \ldots \ldots \ldots \\
12 \\
13 \ldots \ldots \ldots \cdots \\
14 \ldots \ldots \ldots \ldots \\
15, \ldots \ldots \ldots\end{array}$ & $\begin{array}{l}7.1 \\
6.9 \\
7.0 \\
6.5 \\
6.8\end{array}$ & $\begin{array}{l}6.5 \\
6.4 \\
6.8 \\
6.9 \\
\cdots . .\end{array}$ & $\begin{array}{r}6.7 \\
6.2 \\
6.2 \\
6.0\end{array}$ & $\begin{array}{l}6.4 \\
6.4 \\
6.2 \\
6.1 \\
6.3\end{array}$ & $\begin{array}{r}6.4 \\
6.4 \\
6.0 \\
6.1\end{array}$ & $\begin{array}{l}6.2 \\
5.9 \\
6.6 \\
6.3\end{array}$ & $\mid \begin{array}{l}\ldots \ldots \\
\ldots \ldots \ldots \\
\cdots \ldots \\
\cdots \ldots \ldots\end{array}$ \\
\hline $\begin{array}{l}16 \ldots \\
17 \\
18 \ldots \ldots \\
19 \\
20\end{array}$ & $\begin{array}{l}6.6 \\
6.6 \\
6.5 \\
6.7 \\
6.5\end{array}$ & $\begin{array}{l}6.5 \\
6.3 \\
6.0 \\
6.2 \\
5.8\end{array}$ & $\begin{array}{r}6.0 \\
6.5 \\
6.3 . \\
6.0\end{array}$ & $\begin{array}{l}7.0 \\
6.6 \\
6.6 \\
6.4\end{array}$ & $\begin{array}{l}6.1 \\
6.0 \\
6.3 \\
6.3 \\
6.9\end{array}$ & \begin{tabular}{r}
6.3 \\
6.6 \\
\hdashline 6.7 \\
7.2
\end{tabular} & {$\left[\begin{array}{l}\cdots \\
\cdots \\
\cdots \\
\cdots \\
\cdots\end{array}\right.$} \\
\hline $\begin{array}{l}21 \\
223 \\
24 \\
24 \\
25\end{array}$ & $\begin{array}{r}6.9 \\
7.2 \\
6.8 \\
-6.0\end{array}$ & $\begin{array}{l}6.3 \\
6.4 \\
6.1 \\
5.7\end{array}$ & $\begin{array}{l}5.9 \\
6.0 \\
6.3 \\
6.2 \\
6.0\end{array}$ & $\begin{array}{r}6.3 \\
6.4 \\
\dddot{6.1} \\
6.2\end{array}$ & $\begin{array}{l}-6.5 \\
6.3 \\
6.6 \\
6.9\end{array}$ & $\begin{array}{l}7.0 \\
7.3 \\
7.3 \\
7.2 \\
\cdots \cdots\end{array}$ & $\cdots$ \\
\hline 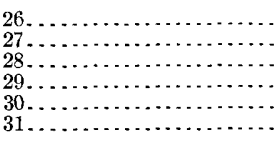 & $\begin{array}{l}6.7 \\
6.6 \\
6.5 \\
6.4 \\
5.8\end{array}$ & $\begin{array}{r}6.1 \\
6.2 \\
6.2 \\
7 . .8 \\
5.8 \\
6.0\end{array}$ & $\begin{array}{l}6.7 \\
6.4 \\
7.2 \\
6.2 \\
5.8\end{array}$ & $\begin{array}{r}6.1 \\
6.0 \\
5.9 \\
5.8 \\
\cdots . . . \\
. . .\end{array}$ & $\begin{array}{r}6.7 \\
6.7 \\
6.7 \\
6.5 \\
6.6\end{array}$ & $\begin{array}{l}8.1 \\
8.1 \\
7.4 \\
7.6 \\
7.1\end{array}$ & 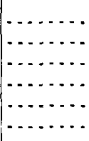 \\
\hline
\end{tabular}

\section{ST. JOSEPII RIVER BASIN.}

\section{DESCRIPTION OF BASIN.}

St. Joseph River rises at Bunday Hills, in northern Hillsdale County, Mich., flows southwestward into Indiana, turns northward at South Bend, recrosses the State line near Bertrand, and debouches into Lake Michigan at St. Joseph. The total area drained is approximately 4,586 square miles, of which 2,916 square miles are in Michigan and 1,670 square miles are in Indiana. The drainage basin contains more than 400 small lakes, varying in surface area from one-eighth of a square mile to 6 square miles. Of these, approximately 100 are in Indiana and 300 in Michigan. No storage is developed on the stream. 
Elkhart River, one of the principal Indiana tributaries of the St. Joseph, drains an area of about 500 square miles, which contains large lakes and extended swamps, the principal fall of the stream occurring in its passage from marsh to marsh.

\section{ST. JOSEPH RIVER AT MENDON, MICH.}

This station is located at the Marantette Bridge, near Mendon, Mich.

Daily gage heights were obtained during 1906, but are not published, owing to the following sources of errors in any estimates of flow which might be based on them: (1) Inaccuracy of discharge measurements caused by the poor natural conditions of flow; (2) backwater from dam below the station; (3) the growth of aquatic plants in the channel, which changes the relation of gage height to discharge during the summer; (4) occasional backwater from Portage Creek, which enters the St. Joseph between the gage and the measuring section and complicates the problem somewhat. This creek flows parallel to and about 1 mile distant from the St. Joseph at Mendon and was at one time diverted across the divide, affording water power with a fall of 20 feet, but this diversion has been discontinued.

A measurement was made April 19, 1906, by D. F. Mott, with the following results:

Width, 100 feet; area, 589 square feet; gage height, 228 feet; discharge, 1,590 second-feet.

ST. JOSEPH RIVER NEAR BUCHANAN, MICH.

This station was established April 1, 1901. It is located at the dam of the South Bend Electric Company, 1 mile below the village of Buchanan. The conditions at this station are described in WaterSupply Paper No. 170, page 20, where are given also references to publications that contain data for previous years.

Daily discharge, in second-feet, of St. Joseph River near Buchanan, Mich., for 1906.

\begin{tabular}{|c|c|c|c|c|c|c|c|c|c|c|c|c|}
\hline & an. & eb. & Tar. & Apr. & ay. & June. & uly. & Aug. & Sept. & Oct. & Nov. & Dec. \\
\hline $\begin{array}{l}1 . \ldots \\
2 \ldots \\
3 \ldots \\
4 \ldots \\
5 \ldots\end{array}$ & $\begin{array}{l}3,394 \\
3,637\end{array}$ & $\begin{array}{l}3,615 \\
3,897\end{array}$ & & $\begin{array}{l}4,983 \\
5,288 \\
4,798 \\
4,505 \\
4,194\end{array}$ & & & & & & $\begin{array}{r}684 \\
1,053 \\
1,327 \\
1,558 \\
1,753\end{array}$ & & $\begin{array}{l}6,481 \\
3,521 \\
3,810 \\
3,202 \\
2,460\end{array}$ \\
\hline $\begin{array}{r}6 . \\
7 . \\
8 . \\
9 . \\
10 .\end{array}$ & & $\begin{array}{l}3,196 \\
2,888 \\
3,245 \\
4,058 \\
3,656\end{array}$ & & & & & & & & & & $\begin{array}{l}3,887 \\
5,811 \\
5,978 \\
5,023 \\
5,558\end{array}$ \\
\hline $5 \ldots$ & $\begin{array}{l}2,701 \\
2,515 \\
2,840\end{array}$ & $\begin{array}{l}3,710 \\
3,823 \\
3,603 \\
3,824\end{array}$ & $\begin{array}{l}4,321 \\
4,764 \\
4,420 \\
4,191 \\
4,036\end{array}$ & $\begin{array}{l}4,804 \\
4,774 \\
4,520 \\
4,739 \\
5,161\end{array}$ & $\begin{array}{l}2,271 \\
2,913 \\
2,929\end{array}$ & $\begin{array}{l}5,909 \\
5,868 \\
5,525 \\
5,535 \\
4,826\end{array}$ & $\begin{array}{l}2,129 \\
2,012 \\
2,133 \\
1,712\end{array}$ & $\begin{array}{l}2,794 \\
2,835 \\
2,462 \\
3,806\end{array}$ & $\begin{array}{l}1,810 \\
1,556 \\
1,868 \\
1,868\end{array}$ & $\begin{array}{r}1,948 \\
1,661 \\
1,595 \\
1,079 \\
935\end{array}$ & $\begin{array}{r}839 \\
1,482 \\
1,773 \\
1,781 \\
1,708\end{array}$ & $\begin{array}{l}5,530 \\
5,503 \\
5,044 \\
5,006\end{array}$ \\
\hline
\end{tabular}

IRR $206-07-3$ 
Daily discharge, in second-feet, of St. Joseph River near Buchanan, Mich., for 1906Continued.

\begin{tabular}{|c|c|c|c|c|c|c|c|c|c|c|c|c|}
\hline Day. & Jan. & Feb. & Mar. & Apr. & May. & June. & July. & Aug. & Sept. & Oct. & Not. & Dec. \\
\hline $\begin{array}{l}16 \ldots \ldots \\
17 \ldots \ldots \\
18 \ldots \ldots \\
19 \ldots \ldots \\
20 \ldots \ldots\end{array}$ & $\begin{array}{l}3,268 \\
2,831 \\
2,929 \\
2,941 \\
3,100\end{array}$ & $\begin{array}{l}3,403 \\
2,914 \\
2,820 \\
3,630 \\
3,387\end{array}$ & $\begin{array}{l}3,899 \\
3,773 \\
3,350 \\
4,033 \\
3,643\end{array}$ & $\begin{array}{l}6,133 \\
5,752 \\
5,635 \\
5,182 \\
4,978\end{array}$ & $\begin{array}{l}3,095 \\
3,406 \\
3,513 \\
3,499 \\
3,572\end{array}$ & $\begin{array}{l}4,696 \\
3,621 \\
4,118 \\
3,646 \\
3,442\end{array}$ & $\begin{array}{l}2,180 \\
1,772 \\
1,537 \\
1,539 \\
1,316\end{array}$ & $\begin{array}{l}1,437 \\
1,838 \\
1,754 \\
1,650 \\
2,125\end{array}$ & $\begin{array}{l}1,324 \\
1,014 \\
1,719 \\
2,028 \\
1,589\end{array}$ & $\begin{array}{l}1,237 \\
1,601 \\
1,537 \\
1,373 \\
1,518\end{array}$ & $\begin{array}{r}1,671 \\
1,849 \\
960 \\
1,820 \\
1,821\end{array}$ & $\begin{array}{l}4,40 \\
5,22 \\
4,23 \\
4,39 \\
3,87\end{array}$ \\
\hline $\begin{array}{l}21 \ldots \ldots \\
22 \ldots \ldots \\
23 \ldots \\
24 \ldots \\
25 \ldots \\
\end{array}$ & $\begin{array}{l}3.157 \\
5,473 \\
8,461 \\
8,648 \\
7,617\end{array}$ & $\begin{array}{l}3,290 \\
3,529 \\
3,568 \\
3,843 \\
3,261\end{array}$ & $\begin{array}{l}3,481 \\
3,294 \\
3,168 \\
3,156 \\
2,853\end{array}$ & $\begin{array}{l}4,630 \\
4,101 \\
4,798 \\
3,915 \\
3,347\end{array}$ & $\begin{array}{l}3,695 \\
3,266 \\
2,880 \\
3,104 \\
2,753\end{array}$ & $\begin{array}{l}3,202 \\
3,044 \\
2,804 \\
2,471 \\
3,111\end{array}$ & $\begin{array}{r}1,624 \\
775 \\
1,722 \\
1,511 \\
1,627\end{array}$ & $\begin{array}{l}1,810 \\
1,907 \\
1,657 \\
1,699 \\
1,521\end{array}$ & $\begin{array}{r}1,638 \\
1,398 \\
573 \\
1,032 \\
1,332\end{array}$ & $\begin{array}{l}1,175 \\
1,050 \\
1,777 \\
1,729 \\
1,646\end{array}$ & $\begin{array}{l}2,069 \\
2,907 \\
2,604 \\
4,032 \\
4,157\end{array}$ & $\begin{array}{l}3,51 \\
3,64 \\
3,05 \\
2,76 \\
2,16\end{array}$ \\
\hline $\begin{array}{l}26 . \\
27 . \\
28 . \\
29 . \\
30 . \\
31 .\end{array}$ & $\begin{array}{l}7,179 \\
7,501 \\
6,856 \\
6,442 \\
6,618 \\
6,382\end{array}$ & $\begin{array}{l}4,418 \\
4,167 \\
3,773\end{array}$ & $\begin{array}{l}3,781 \\
4,169 \\
5,718 \\
5,528 \\
5,501 \\
5,568\end{array}$ & \begin{tabular}{|}
3,672 \\
4,074 \\
3,822 \\
3,500 \\
3,911 \\
$\ldots \ldots \ldots$
\end{tabular} & $\begin{array}{l}2,588 \\
2,542 \\
3,145 \\
3,145 \\
2,987 \\
2,949\end{array}$ & $\begin{array}{l}2,821 \\
2,490 \\
2,537 \\
2,303 \\
2,282\end{array}$ & $\begin{array}{r}1,512 \\
1,323 \\
1,348 \\
930 \\
1,906 \\
1,631\end{array}$ & $\begin{array}{l}1,195 \\
2,204 \\
1,929 \\
1,933 \\
1,258 \\
1,479\end{array}$ & $\begin{array}{r}1,122 \\
1,325 \\
989 \\
1,639 \\
756\end{array}$ & $\begin{array}{l}1,559 \\
1,391 \\
1,100 \\
1,611 \\
1,781 \\
1,824\end{array}$ & $\begin{array}{r}4,821 \\
4,656 \\
4,599 \\
4,516 \\
4,210 \\
\end{array}$ & $\begin{array}{l}2,64 \\
2,97 \\
3,24 \\
3,06 \\
3.42 \\
3,98\end{array}$ \\
\hline
\end{tabular}

Monthly discharge of St. Joseph River near Buchanan, Mich., for 1906.

[Drainage area, 3,940 square miles.]

\begin{tabular}{|c|c|c|c|c|c|}
\hline \multirow[b]{2}{*}{ Month. } & \multicolumn{3}{|c|}{ Discharge in second-feet. } & \multicolumn{2}{|c|}{ Run-off. } \\
\hline & Maximum. & Minimum. & Mean. & $\begin{array}{l}\text { Sec.-ft. per } \\
\text { sq. mile. }\end{array}$ & $\begin{array}{l}\text { Depth ir } \\
\text { inches. }\end{array}$ \\
\hline 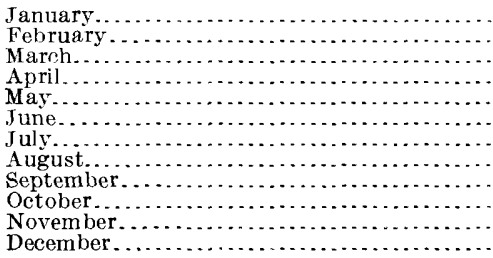 & $\begin{array}{l}8,650 \\
6,0<0 \\
6,070 \\
6,130 \\
3,800 \\
5,910 \\
2,480 \\
4,540 \\
2,190 \\
2,060 \\
4,820 \\
6,480\end{array}$ & $\begin{array}{r}2,520 \\
2,820 \\
2,850 \\
3,350 \\
2,180 \\
2,210 \\
775 \\
1,200 \\
573 \\
684 \\
839 \\
2,160\end{array}$ & $\begin{array}{l}4,400 \\
3,700 \\
4,390 \\
4,550 \\
3,060 \\
3,460 \\
1,780 \\
2,030 \\
1,500 \\
1,470 \\
2,370 \\
4,170\end{array}$ & $\begin{array}{l}1.12 \\
.939 \\
1.11 \\
1.15 \\
.777 \\
.878 \\
.452 \\
.515 \\
.381 \\
.373 \\
.602 \\
1.06\end{array}$ & $\begin{array}{r}1.2 \\
.9 \\
1.2 \\
1.2 \\
.9 \\
.9 \\
.5 \\
.5 \\
.4 \\
.4 \\
.6 \\
1.2\end{array}$ \\
\hline The year. & 8,650 & 573 & 3,070 & .780 & 10.5 \\
\hline
\end{tabular}

KALAMAZOO RIVER BASIN.

\section{DESCRIPTION OF BASIN.}

Kalamazoo River rises in southwestern Jackson County, Mich. flows in a general northwesterly direction, and enters Lake Michigar at Saugatuck. Its length is about 100 miles.

Owing to its steady regimen the Kalamazoo is of great value fo water power. Within the past five years three dams and powe plants have been constructed to generate electricity for electri traction. An additional plant for this purpose is now under con struction at Ceresco. Water power is also used for general manufac turing purposes at Allegan, Battle Creek, Albion, and other points. 


\section{REED'S SPRINGS, NEAR ALBION, MICH.}

A gaging station was established at this place December 7 and 8 1904, for the purpose of obtaining information concerning the permanence of the supply furnished to streams by the numerous springs in the moraines. It was discontinued June 30, 1906. The conditions at this station are described in Water-Supply Paper No. 171 page 24 .

Gage height, in feet, and discharge, in second-feet, of Reed's springs, near Albion, Mich. for 1906 .

\begin{tabular}{|c|c|c|c|c|c|}
\hline Date. & $\begin{array}{c}\text { Gage. } \\
\text { height on } \\
\text { weir. }\end{array}$ & Discharge. & Date. & $\begin{array}{c}\text { Gage } \\
\text { height on } \\
\text { weir. }\end{array}$ & Discharge \\
\hline 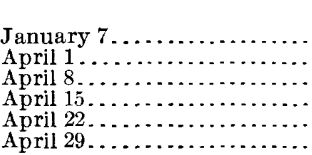 & $\begin{array}{l}\text { Feet. } \\
1.09 \\
1.10 \\
1.10 \\
1.10 \\
1.10 \\
1.10\end{array}$ & \begin{tabular}{r|} 
Sec.-feet. \\
2.66 \\
2.75 \\
2.75 \\
2.75 \\
2.75 \\
2.75
\end{tabular} & 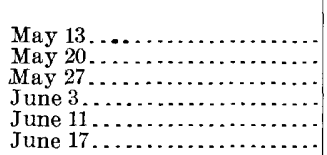 & $\begin{array}{l}\text { Feet. } \\
1.10 \\
1.10 \\
1.10 \\
1.10 \\
1.10 \\
1.10\end{array}$ & $\begin{array}{r}\text { Sec.-feet. } \\
2.7 \\
2.7 \\
2.7 \\
2.7 \\
2.7 \\
2.7\end{array}$ \\
\hline
\end{tabular}

\section{GRAND RIVER BASIN.}

\section{DESCRIPTION OF BASIN.}

Grand River rises in the southern part of Jackson County, Mich. flows in a general northerly and northwesterly direction, and empties into Lake Michigan at Grand Haven. Its drainage area, which com. prises a rich agricultural region in the south-central portion of Michigan, includes extensive swamps and marshes but comparatively few lakes. At Grand Rapids the stream passes over a limestone ledge, making a considerable fall, which has been developed for power purposes, and at Grand Ledge a similar descent occurs oves sandstone.

The Grand receives a number of important tributaries, notably Flat, Thornapple, Maple, Lookingglass, and Red Cedar rivers.

\section{GRAND RIVER AT NORTH LANSING, MICH.}

This station was established March 2, 1901, and was discontinuec August 4, 1906. It was located at the Seymour Street Bridge, $\varepsilon$ short distance below the North Lansing dam. The conditions a this station and the bench marks are described in Water-Supply Paper No. 170, page 26, where are given also references to publica tions that contain data for previous years. 
Discharge measurements of Grand River at North Lansing, Mich., in 1906.

\begin{tabular}{|c|c|c|c|c|c|}
\hline Date. & Hydrographer. & Width. & $\begin{array}{l}\text { Area of } \\
\text { section. }\end{array}$ & $\begin{array}{c}\text { Gage } \\
\text { height. }\end{array}$ & $\begin{array}{l}\text { Dis- } \\
\text { charge. }\end{array}$ \\
\hline $\begin{array}{l}\text { April } 20 . \\
\text { June } 16 . .\end{array}$ & $\begin{array}{l}\text { D. L. Mott } \\
\text { Horton and Covert }\end{array}$ & $\begin{array}{r}\text { Feet. } \\
177 \\
183\end{array}$ & $\begin{array}{r}S q . f t . \\
966 \\
811\end{array}$ & $\begin{array}{l}\text { Feet. } \\
4.90 \\
a 5.20\end{array}$ & $\begin{array}{r}\text { Sec.-ft. } \\
1,780 \\
1,400\end{array}$ \\
\hline
\end{tabular}

a Uncertain.

Daily gage height, in feet, of Grand River at North Lansing, Mich., for 1906.

\begin{tabular}{|c|c|c|c|c|c|c|c|c|}
\hline Day. & Jan. & Feb. & Mar. & Apr. & May. & June. & July. & Aug. \\
\hline 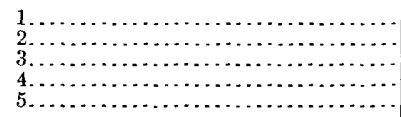 & $\begin{array}{l}3.24 \\
3.13 \\
2.98 \\
3.02 \\
3.08\end{array}$ & $\begin{array}{l}4.69 \\
3.75 \\
\text { 3. } 44 \\
3.22 \\
4.02\end{array}$ & $\begin{array}{l}3.59 \\
3.43 \\
6.08 \\
6.82 \\
6.37\end{array}$ & $\begin{array}{l}5.23 \\
4.57 \\
4.33 \\
4.53 \\
3.68\end{array}$ & $\begin{array}{l}2.95 \\
3.02 \\
3.39 \\
3.27 \\
2.96\end{array}$ & $\begin{array}{l}3.02 \\
2.80 \\
2.27 \\
2.52 \\
2.97\end{array}$ & $\begin{array}{l}2.08 \\
2.33 \\
1.93 \\
1.98 \\
2.68\end{array}$ & $\begin{array}{r}2.30 \\
2.55 \\
2.35 \\
3.05 \\
\ldots .\end{array}$ \\
\hline 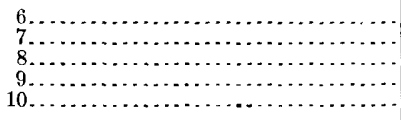 & $\begin{array}{l}3.09 \\
2.55 \\
2.47 \\
2.54 \\
2.52\end{array}$ & $\begin{array}{l}3.58 \\
3.42 \\
3.27 \\
3.15 \\
3.09\end{array}$ & $\begin{array}{l}6.24 \\
5.42 \\
4.88 \\
4.60 \\
3.96\end{array}$ & $\begin{array}{l}4.07 \\
4.17 \\
4.02 \\
4.74 \\
5.27\end{array}$ & $\begin{array}{l}2.63 \\
2.95 \\
2.70 \\
2.75 \\
2.82\end{array}$ & $\begin{array}{l}2.43 \\
2.38 \\
5.12 \\
9.23 \\
9.88\end{array}$ & $\begin{array}{l}2.70 \\
2.52 \\
2.63 \\
2.48 \\
2.35\end{array}$ & 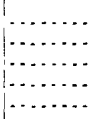 \\
\hline 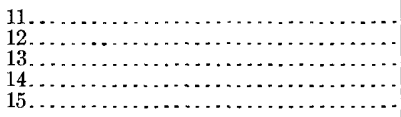 & $\begin{array}{l}2.56 \\
2.66 \\
2.42 \\
2.14 \\
2.96\end{array}$ & $\begin{array}{l}2.42 \\
2.98 \\
2.66 \\
3.06 \\
3.44\end{array}$ & $\begin{array}{l}4.18 \\
3.39 \\
3.86 \\
3.56 \\
3.32\end{array}$ & $\begin{array}{l}5.43 \\
5.05 \\
4.98 \\
5.18 \\
6.58\end{array}$ & $\begin{array}{l}2.91 \\
2.72 \\
2.52 \\
3.33 \\
4.23\end{array}$ & $\begin{array}{l}8.57 \\
7.43 \\
6.07 \\
5.50 \\
4.60\end{array}$ & $\begin{array}{l}2.08 \\
2.05 \\
2.15 \\
2.07 \\
2.10\end{array}$ & $\begin{array}{l}\ldots \ldots \\
\ldots \ldots \\
\ldots \ldots \\
\ldots \ldots \\
\ldots \ldots\end{array}$ \\
\hline $\begin{array}{l}16 \\
17 \\
18 \\
19 \\
20\end{array}$ & $\begin{array}{l}3.48 \\
3.88 \\
3.48 \\
3.54 \\
\text { 3. } 76\end{array}$ & $\begin{array}{l}3.02 \\
2.70 \\
2.20 \\
2.66 \\
2.51\end{array}$ & $\begin{array}{l}3.46 \\
3.14 \\
2.80 \\
3.20 \\
2.96\end{array}$ & $\begin{array}{l}6.78 \\
6.35 \\
5.52 \\
5.52 \\
4.73\end{array}$ & $\begin{array}{l}4.45 \\
3.89 \\
3.87 \\
3.28 \\
3.02\end{array}$ & $\begin{array}{l}4.05 \\
3.31 \\
3.46 \\
3.33 \\
2.97\end{array}$ & $\begin{array}{l}2.35 \\
2.30 \\
2.03 \\
2.08 \\
2.00\end{array}$ & $\begin{array}{ll}\cdots \ldots \ldots \\
\cdots \ldots \\
\cdots\end{array}$ \\
\hline $\begin{array}{l}21 \ldots \ldots \ldots \\
22, \ldots \ldots \\
23 \ldots \ldots \\
24 \\
25 \ldots \ldots\end{array}$ & $\begin{array}{l}5.89 \\
7.56 \\
8.92 \\
9.14 \\
8.5\end{array}$ & $\begin{array}{l}3.48 \\
3.93 \\
3.79 \\
3.78 \\
3.70\end{array}$ & $\begin{array}{l}2.99 \\
2.90 \\
2.66 \\
\text { 2. } 76 \\
\text { 2. } 41\end{array}$ & $\begin{array}{l}4.00 \\
4.27 \\
3.42 \\
3.37 \\
3.48\end{array}$ & $\begin{array}{l}2.88 \\
2.90 \\
2.55 \\
2.42 \\
2.42\end{array}$ & $\begin{array}{l}3.02 \\
2.90 \\
2.63 \\
2.53 \\
2.72\end{array}$ & $\begin{array}{l}2.05 \\
2.03 \\
2.33 \\
2.10 \\
2.18\end{array}$ & $\begin{array}{ll}\cdots \\
\cdots \\
\cdots\end{array}$ \\
\hline $\begin{array}{l}26 \ldots \ldots \ldots \\
27 \ldots \ldots \\
28 \ldots \\
29 \ldots \ldots \\
30 \ldots \ldots \\
31 \ldots \ldots\end{array}$ & $\begin{array}{l}7.26 \\
6.42 \\
5.77 \\
5.34 \\
5.01 \\
4.61\end{array}$ & $\begin{array}{r}4.40 \\
3.94 \\
3.30 \\
. . . .\end{array}$ & $\begin{array}{l}3.44 \\
5.10 \\
6.72 \\
6.90 \\
6.36 \\
5.60\end{array}$ & $\begin{array}{l}3.45 \\
3.20 \\
3.10 \\
3.17 \\
3.23 \\
\ldots . . .\end{array}$ & $\begin{array}{l}2.42 \\
1.82 \\
3.13 \\
3.38 \\
2.97 \\
3.07\end{array}$ & $\begin{array}{r}2.47 \\
2.40 \\
2.20 \\
2.37 \\
2.17 \\
\ldots . . .\end{array}$ & $\begin{array}{l}2.08 \\
2.15 \\
2.17 \\
1.83 \\
2.33 \\
2.43\end{array}$ & 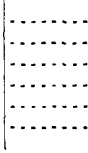 \\
\hline
\end{tabular}

Rating table for Grand River at North Lansing, Mich., for 1906.

\begin{tabular}{|c|r|r|r|r|r|r|r|}
\hline $\begin{array}{c}\text { Gage } \\
\text { height. }\end{array}$ & $\begin{array}{c}\text { Dis- } \\
\text { charge. }\end{array}$ & $\begin{array}{c}\text { Gage } \\
\text { height. }\end{array}$ & $\begin{array}{c}\text { Dis- } \\
\text { charge. }\end{array}$ & $\begin{array}{c}\text { Gage } \\
\text { height. }\end{array}$ & $\begin{array}{c}\text { Dis- } \\
\text { charge. }\end{array}$ & $\begin{array}{c}\text { Gage } \\
\text { height. }\end{array}$ & $\begin{array}{c}\text { Dis- } \\
\text { charge. }\end{array}$ \\
\cline { 1 - 4 } Feet. & Sec.-ft. & Fect. & Sec.ft. & Feet. & Sec.-ft. & Feet. & Sec.-ft. \\
1.80 & 251 & 3.10 & 761 & 4.40 & 1,420 & 6.40 & 2,730 \\
1.90 & 281 & 3.20 & 807 & 4.50 & 1,475 & 6.60 & 2,900 \\
2.00 & 313 & 3.30 & 854 & 4.60 & 1,530 & 6.80 & 3,080 \\
2.10 & 347 & 3.40 & 902 & 4.70 & 1,585 & 7.00 & 3,260 \\
2.20 & 383 & 3.50 & 950 & 4.80 & 1,640 & 7.20 & 3,445 \\
2.30 & 421 & 3.60 & 999 & 4.90 & 1,700 & 7.40 & 3,635 \\
2.40 & 461 & 3.70 & 1,049 & 5.00 & 1,760 & 7.60 & 3,830 \\
2.50 & 502 & 3.80 & 1,099 & 5.20 & 1,880 & 7.80 & 4,030 \\
2.60 & 544 & 3.90 & 1,149 & 5.40 & 2,000 & 8.00 & 4,240 \\
2.70 & 586 & 4.00 & 1,200 & 5.60 & 2,130 & 9.00 & 5,370 \\
2.80 & 629 & 4.10 & 1,255 & 5.80 & 2,265 & 10.00 & 6,680 \\
2.90 & 672 & 4.20 & 1,310 & 6.00 & 2,405 & & \\
3.00 & 716 & 4.30 & 1,365 & 6.20 & 2,565 & & \\
\hline
\end{tabular}

Note.-The above table is applicable only for open-channel conditions. It is based on discharge measurements made during 1902-1906, and is well defined below gage heights 5.4 feet and fairly well above gage height 5.4 feet. 
Monthly discharge of Grand River at North Lansing, Mich., for 1906.

[Drainage area, 1,230 square miles.]

\begin{tabular}{|c|c|c|c|c|c|}
\hline \multirow[b]{2}{*}{ Month. } & \multicolumn{3}{|c|}{ Discharge in second-feet. } & \multicolumn{2}{|c|}{ Run-off. } \\
\hline & Maximum. & Minimum. & Mean. & $\begin{array}{l}\text { Sec.-ft. per } \\
\text { sq. mile. }\end{array}$ & $\begin{array}{l}\text { Depth in } \\
\text { inches. }\end{array}$ \\
\hline 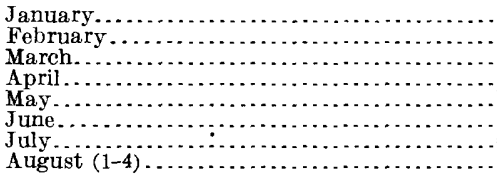 & $\begin{array}{r}5,540 \\
1,580 \\
3,170 \\
3,060 \\
1,450 \\
6,510 \\
586 \\
738\end{array}$ & $\begin{array}{l}361 \\
383 \\
465 \\
761 \\
257 \\
372 \\
260 \\
421\end{array}$ & $\begin{array}{r}1,610 \\
887 \\
1,450 \\
1,530 \\
737 \\
1,410 \\
392 \\
531\end{array}$ & $\begin{array}{l}1.31 \\
.721 \\
1.18 \\
1.24 \\
.599 \\
1.15 \\
.319 \\
.432\end{array}$ & $\begin{array}{r}1.5 \\
.7 \\
1.3 \\
1.3 \\
.6 \\
1.2 \\
.3 \\
.0\end{array}$ \\
\hline
\end{tabular}

Note.-Values are rated as follows: January to March and June, good; remainder of the period excellent.

\section{GRAND RIVER AT GRAND RAPIDS, MICH.}

This station was established March 12, 1901, by L. W. Anderson city engineer of Grand Rapids. It is located at the Fulton Stree Bridge. The gage is read by assistants in city engineer's office.

The conditions at this station and the bench marks are describec in Water-Supply Paper No. 170, page 29, where are given also ref. erences to publications that contain data for previous years.

A measurement was made during 1906 at gage height 7.58 feet which indicated a discharge nearly 25 per cent in excess of the ratin used for 1905. Owing to lack of data tending either to confirm of discredit this measurement, it was considered inadvisable to makt estimates of flow for 1906. It is believed, however that the 190? rating probably applies correctly for 1906.

Daily gage height, in feet, of Grand River at Grand Rapids, Mich., for 1906.

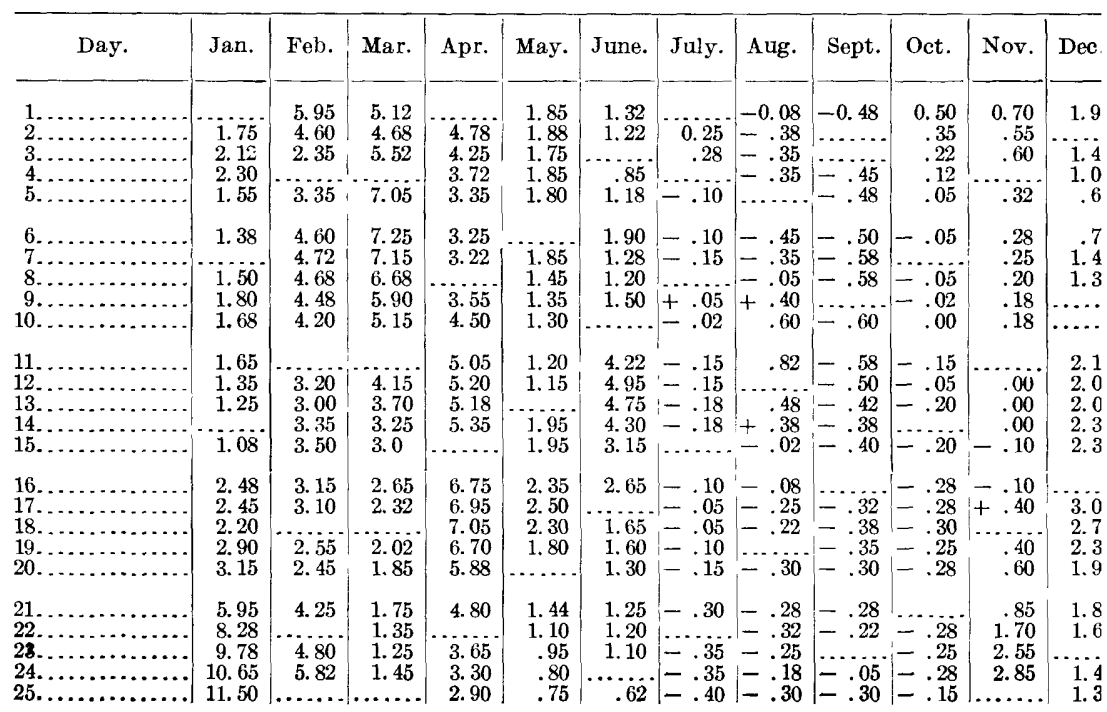


Daily gage height, in feet, of Grand River at Grand Rapids, Mich., for 1906-Continued.

\begin{tabular}{c|r|r|r|r|r|r|r|r|r|r|r|r}
\hline Day. & Jan. & Feb. & Mar. & Apr. & May. & June. & July. & Aug. & Sept. & Oct. & Nov. & Dee. \\
\hline $26 \ldots \ldots$ & & & & & & & \\
\hline
\end{tabular}

\section{MUSKEGON RIVER BASIN.}

\section{DESCRIPTION OF BASIN.}

Muskegon River drains an area 2,663 square miles in extent, lying directly north of the Grand River basin. Its headwaters rise in the north-central part of the southern peninsula of Michigan, whence it flows in a general southwesterly direction until it enters Lake Michigan near the city of Muskegon.

From the vicinity of Evart to Newaygo the Muskegon flows between high banks and has a rapid fall. Levels run for the purpose show that within a distance of 10 miles -5 miles each way from Big Rapids - there is a total fall of 104 feet, practically all of which could be economically developed, as there are favorable sites for the location of dams.

In connection with power development good opportunities exist for the conservation of flow by artificial storage. The water surface areas of the principal lakes of the watershed and of the tributary drainage which they control are given below:

Drainage and surface areas of lakes in Muskegon River watershed.

\begin{tabular}{|c|c|c|}
\hline Lake. & $\begin{array}{c}\text { Drainage } \\
\text { area. }\end{array}$ & $\begin{array}{c}\text { Water } \\
\text { surface. }\end{array}$ \\
\hline Muskrat Lake and group & Sq. miles & $\begin{array}{r}\text { Sq. miles. } \\
8.0\end{array}$ \\
\hline Clam Lakes.............. & 67 & 6.7 \\
\hline Higgins Lake. . & 67 & 1.5. 0 \\
\hline Houghton Lake..$\ldots \ldots \ldots \ldots \ldots \ldots$ & 185 & 31.0 \\
\hline Higgins and Houghton la & & \\
\hline
\end{tabular}

In the upper portion of the watershed there is a total lake area of about 110 square miles. Formerly a lumberman's dam was maintained for the purpose of flooding logs between Higgins and Houghton lakes, but this has been washed out. A lumberman's dam, built of logs and earth, which still remains about 1 mile below the foot of Houghton Lake, raises the water level in that lake 4 feet, providing a storage of $3,350,000,000$ cubic feet in round numbers. 


\section{MUSKEGON RIVER AT NEWAYGO, MICH.}

This station was established in March, 1901. It is located at the dam of the Newaygo Portland Cement Company, which crosses the Muskegon in a deep valley above the village of Newaygo. The conditions at this station are described in Water-Supply Paper No. 170, page 32 , where are given also references to publications that contain data for previous years.

Daily discharge, in second-feet, of Muskegon River at Neuaygo, Mich., for 1906.

\begin{tabular}{|c|c|c|c|c|c|c|c|c|c|c|c|c|}
\hline D & Jan. & Feb. & Mar. & Apr. & Iay. & ine. & July. & Aug. & Sept. & Oct. & Jov. & Dec. \\
\hline & $\begin{array}{l}1,970 \\
2,172 \\
2,154 \\
2,115 \\
1,872\end{array}$ & $\begin{array}{l}2,237 \\
1,748 \\
2,128 \\
2,273 \\
2,314\end{array}$ & $\begin{array}{r}1,389 \\
1,309 \\
1,190 \\
1,302 \\
648\end{array}$ & $\begin{array}{l}244 \\
246 \\
165\end{array}$ & $\begin{array}{r}977 \\
1,085 \\
1,607 \\
1,784 \\
999\end{array}$ & $\begin{array}{l}1,050 \\
1,148 \\
1,233 \\
1,143 \\
1,204\end{array}$ & $\begin{array}{l}1,082 \\
1,059 \\
1,103 \\
1,188 \\
1,103\end{array}$ & $\begin{array}{r}881 \\
1,073 \\
884 \\
910 \\
814\end{array}$ & $\begin{array}{l}894 \\
926 \\
878\end{array}$ & $\begin{array}{r}1,408 \\
1,113 \\
971 \\
1,137 \\
984\end{array}$ & $\begin{array}{l}1,387 \\
1,418 \\
1,469 \\
1,243 \\
1,412\end{array}$ & $\begin{array}{l}3,417 \\
2,837 \\
2,488 \\
2,063 \\
1,951\end{array}$ \\
\hline $\begin{array}{l}6 . \\
7 . \\
8 . \\
9 .\end{array}$ & $\begin{array}{l}1,899 \\
2,049 \\
1,971 \\
1,793 \\
1,795\end{array}$ & $\begin{array}{l}2,172 \\
2,139 \\
2,019 \\
2,041 \\
1,681\end{array}$ & $\begin{array}{r}777 \\
851 \\
777 \\
1,124 \\
1,567\end{array}$ & $\begin{array}{l}3,240 \\
3,549\end{array}$ & $\begin{array}{l}1,502 \\
1,555 \\
1,624 \\
1,453 \\
1,472\end{array}$ & & & $\begin{array}{r}926 \\
927 \\
945 \\
1,043 \\
1,461\end{array}$ & & & $\begin{array}{l}1,226 \\
1,257 \\
1,289 \\
1,223 \\
1,262\end{array}$ & $\begin{array}{l}1,78 \\
1,63 \\
1,10 \\
1,29 \\
1,12\end{array}$ \\
\hline & $\begin{array}{l}1,981 \\
2,202 \\
1,953 \\
2,323\end{array}$ & $\begin{array}{l}1,576 \\
1,767 \\
2,202 \\
1,650 \\
1,456\end{array}$ & $\begin{array}{l}1,529 \\
1,277 \\
1,049\end{array}$ & $\begin{array}{l}1,912 \\
1,836 \\
2,360\end{array}$ & $\begin{array}{r}1,050 \\
977 \\
1,015 \\
1,634 \\
984\end{array}$ & & & 10 & & $\begin{array}{l}1,158 \\
1,158 \\
1,225 \\
1,249 \\
1,105\end{array}$ & $\begin{array}{l}1,169 \\
1,181 \\
1,101 \\
1,208\end{array}$ & $\begin{array}{l}1,4 \\
1,3 \\
2,2\end{array}$ \\
\hline 9. & $\begin{array}{l}2,584 \\
2,793 \\
2,662 \\
2,699\end{array}$ & $\begin{array}{l}1,987 \\
1,859 \\
2,598\end{array}$ & $\begin{array}{r}2,017 \\
609 \\
1,528 \\
907\end{array}$ & $\begin{array}{l}2,080 \\
1,291\end{array}$ & $\begin{array}{l}1,082 \\
1,388 \\
1,130 \\
1,083\end{array}$ & $\begin{array}{r}1,270 \\
1,143 \\
1,111 \\
947 \\
1,178\end{array}$ & & $\begin{array}{l}833 \\
860 \\
926 \\
830\end{array}$ & $\begin{array}{l}990 \\
878 \\
782\end{array}$ & $\begin{array}{l}1,120 \\
1,067 \\
1,258 \\
1,233 \\
1,196\end{array}$ & $\begin{array}{l}1,240 \\
1,333 \\
2,207 \\
2,256\end{array}$ & 2,1 \\
\hline 3. & & $\begin{array}{l}2,577 \\
1,317 \\
1,294 \\
1,381 \\
1,652\end{array}$ & $\begin{array}{l}1,946 \\
1,931 \\
1,627 \\
1,498 \\
1,525\end{array}$ & $\begin{array}{r}1,284 \\
1,145 \\
1.079 \\
1,048 \\
912\end{array}$ & $\begin{array}{r}1,115 \\
1,090 \\
958 \\
1,136 \\
1,255\end{array}$ & $\begin{array}{l}1,176 \\
1,082 \\
1,147 \\
1,227 \\
1,082\end{array}$ & $\begin{array}{r}989 \\
1,062 \\
829 \\
1,014\end{array}$ & $\begin{array}{l}901 \\
901 \\
846\end{array}$ & $\begin{array}{r}1,207 \\
906\end{array}$ & $\begin{array}{l}1,286 \\
1,281 \\
1,186 \\
1,164 \\
1,313\end{array}$ & $\begin{array}{l}2,570 \\
3,055 \\
2,615 \\
2,628\end{array}$ & $\begin{array}{l}2,172 \\
2,098 \\
1,688 \\
1,72 \\
1,80\end{array}$ \\
\hline $\begin{array}{l}28 . \\
29 . \\
30 .\end{array}$ & $\begin{array}{l}2,614 \\
2,218 \\
2,226 \\
2,109 \\
2,243\end{array}$ & $\begin{array}{r}1,482 \\
1,413 \\
929\end{array}$ & $\begin{array}{l}1,359 \\
1,208 \\
2,427 \\
2,374 \\
2,551 \\
2,722\end{array}$ & $\begin{array}{r}1,145 \\
1,248 \\
1,228 \\
907 \\
1,149\end{array}$ & $\begin{array}{l}1,260 \\
1,387 \\
1,484 \\
1,223 \\
1,422 \\
1,127\end{array}$ & $\begin{array}{l}1,068 \\
1,075 \\
1,098 \\
1,002 \\
1,036\end{array}$ & $\begin{array}{l}1,167 \\
1,060 \\
1,104 \\
1,082 \\
1,159\end{array}$ & $\begin{array}{l}854 \\
842 \\
881 \\
812 \\
780 \\
926\end{array}$ & $\begin{array}{l}1,144 \\
1,015 \\
1,081 \\
1,191 \\
1,728\end{array}$ & $\begin{array}{l}1,376 \\
1,345 \\
1,686 \\
1,835 \\
1,606 \\
1,418\end{array}$ & $\begin{array}{l}3,196 \\
4,070 \\
3,891 \\
3,648 \\
3,610\end{array}$ & $\begin{array}{l}1,511 \\
1,954 \\
1,785 \\
1,909 \\
1,795 \\
1,880\end{array}$ \\
\hline
\end{tabular}

Note.-Ice conditions Fanuary 21 to 26.

Monthly discharge of Muskegon River at Newaygo, Mich., for 1906.

[Drainage area, 2,350 square miles.]

\begin{tabular}{|c|c|c|c|c|c|}
\hline \multirow[b]{2}{*}{ Month. } & \multicolumn{3}{|c|}{ Discharge in second-feet. } & \multicolumn{2}{|c|}{ Run-off. } \\
\hline & Maximum. & Minimum. & Mean. & $\left\{\begin{array}{l}\text { Sec.-ft. per } \\
\text { sq. mile. }\end{array}\right.$ & $\begin{array}{l}\text { Depth in } \\
\text { inches. }\end{array}$ \\
\hline 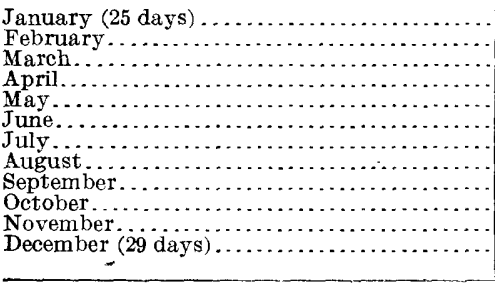 & $\begin{array}{l}3,060 \\
2,600 \\
2,720 \\
3,550 \\
1,780 \\
1,270 \\
1,190 \\
1,460 \\
1,730 \\
1,840 \\
4,070 \\
3,420\end{array}$ & $\begin{array}{r}1,790 \\
929 \\
609 \\
907 \\
958 \\
947 \\
829 \\
780 \\
734 \\
971 \\
1,100 \\
1,100\end{array}$ & $\begin{array}{r}2,220 \\
1,850 \\
1,480 \\
1,870 \\
1,250 \\
1,120 \\
1,080 \\
914 \\
947 \\
1,250 \\
1,960 \\
1,920\end{array}$ & $\begin{array}{r}0.945 \\
.787 \\
.630 \\
.796 \\
.532 \\
.477 \\
.460 \\
.389 \\
.424 \\
.532 \\
.834 \\
.817\end{array}$ & $\begin{array}{l}0.88 \\
.82 \\
.73 \\
.89 \\
.61 \\
.53 \\
.53 \\
.45 \\
.47 \\
.61 \\
.93 \\
.85\end{array}$ \\
\hline
\end{tabular}




\section{MANISTEE RIVER BASIN.}

\section{DESCRIPTION OF BASIN.}

Manistee River is the northernmost of the group of three large rivers draining the western part of the southern peninsula of Michigan. It has its source in southeastern Antrim County, flows in a general southwesterly direction, and enters Lake Michigan at the city of Manistee, an important lumber center. The harbor at the mouth of the river is excellent. The fall is gradual and no important utilization of the water power has been made, the principal use of the stream being for rafting logs.

\section{MANISTEE RIVER NEAR SHERMAN, MICH.}

This station was established July 10, 1903, at North Bridge, near Sherman. The conditions at this station and the bench marks are described in Water-Supply Paper No. 170, page 34, where are given also references to publications that contain data for previous years.

A measurement was made June 30, 1906, by Horton and Covert, with the following results:

Width, 68 feet; area, 409 square feet; gage height, 2.36 feet; clischarge, 988 secondfeet.

Daily gage height, in feet, of Manistee River near Sherman, Mich., for 1906.

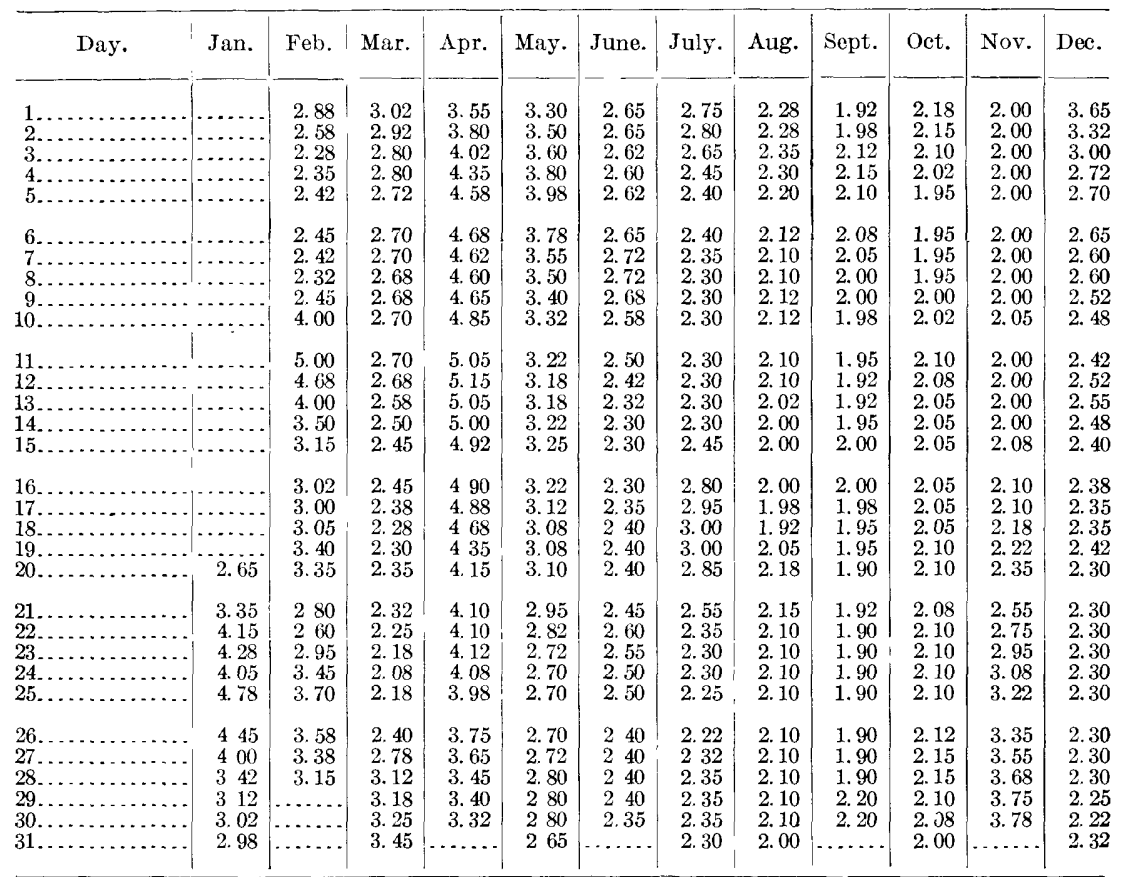

Note.-On February 1 a jam of logs several miles below the station stopped the flow of slusn ice, which hacked up several miles above the gage and froze; this ice went out February 17. 


\section{LAKE HURON DRAINAGE.}

\section{GENERAL FEATURES.}

The area tributary to Lake Huron in the United States comprises the eastern part of the southern peninsula of Michigan. South of Saginaw Bay the Lake Huron slope is very narrow and the brooks and runnels by which it is drained are only a few miles in length. The so-called Thumb of the Mitten is drained chiefly by three short, northward-flowing streams known as Willow, Pinnepog, and Pigeon rivers, which lie in a flat, marshy region. The Saginaw River system is tributary to the bay at its head, while northward from the bay are Rifle, Au Sable, and Thunder Bay rivers, streams having considerable fall, excellent ground storage, and well-sustained flow. Cheboygan River also belongs in the Lake Huron drainage.

\section{AU SABLE RIVER BASIN.}

\section{DESCRIPTION OF BASIN.}

$\mathrm{Au}$ Sable River rises in southern Otsego County and follows a tortuous course in a general southeasterly direction to its outlet in Lake Huron at Oscoda, Mich. Numerous small lakes, wet sand areas, and undrained hollows occur. Rock outcrops are very rare, the stream bed being usually clay or sand. The tributaries are unimportant, nearly all the rainfall being absorbed by the porous sand areas. At Bamfield, about 40 miles from the outlet, following the river, the elevation is about 850 feet above sea level, and from this point to the mouth of the stream excellent sites for water-power development occur.

\section{AU SABLE RIVER AT BAMFIELD, MICH.}

This station was established August 27, 1902. It is located at the highway bridge at Bamfield. The conditions at this station and the bench marks are described in Water-Supply Paper No. 170, page 38, where are given also references to publications that contain data for previous years.

Daily gage height, in feet, of Au Sable River at Bamfield, Mich., for 1906.

\begin{tabular}{|c|c|c|c|c|c|c|c|c|c|c|c|c|}
\hline Day. & Jan. & Feb. & Mar. & Apr. & May. & June. & July. & Aug. & Sept. & Oct. & Nov. & Dec. \\
\hline $\begin{array}{l}1 \ldots \ldots \\
2 \ldots \ldots \\
3 \ldots \ldots \\
4 \ldots \ldots \\
5 \ldots \ldots\end{array}$ & $\begin{array}{l}1.0 \\
1.0 \\
1.1 \\
1.1 \\
1.0\end{array}$ & $\begin{array}{l}1.6 \\
1.6 \\
1.4 \\
1.4 \\
1.4\end{array}$ & $\begin{array}{l}1.8 \\
1.7 \\
1.7 \\
1.7 \\
1.6\end{array}$ & $\begin{array}{l}2.5 \\
2.7 \\
2.95 \\
3.25 \\
3.6\end{array}$ & $\begin{array}{l}2.0 \\
2.0 \\
2.0 \\
2.0 \\
2.0\end{array}$ & $\begin{array}{l}1.8 \\
1.8 \\
1.8 \\
1.9 \\
1.8\end{array}$ & $\begin{array}{l}2.0 \\
1.1 \\
1.1 \\
1.1 \\
1.1\end{array}$ & $\begin{array}{l}1.5 \\
1.2 \\
1.1 \\
1.05 \\
1.05\end{array}$ & $\begin{array}{l}1.1 \\
1.1 \\
1.2 \\
1.1 \\
1.1\end{array}$ & $\begin{array}{l}1.1 \\
1.1 \\
1.1 \\
1.1 \\
1.1\end{array}$ & $\begin{array}{l}1.1 \\
1.2 \\
1.2 \\
1.3 \\
1.2\end{array}$ & $\begin{array}{l}2.9 \\
2.95 \\
3.05 \\
3.0 \\
3.2\end{array}$ \\
\hline $\begin{array}{r}6 \ldots \\
7 \ldots \\
8 \ldots \\
9 \ldots \\
10 \ldots\end{array}$ & $\begin{array}{l}1.0 \\
1.0 \\
1.0 \\
0.9 \\
0.9\end{array}$ & $\begin{array}{l}2.5 \\
2.2 \\
2.6 \\
3.0 \\
2.4\end{array}$ & $\begin{array}{l}1.6 \\
1.6 \\
1.5 \\
1.5 \\
1.5\end{array}$ & $\begin{array}{l}3.65 \\
2.9 \\
3.0 \\
3.1 \\
3.5\end{array}$ & $\begin{array}{l}2.1 \\
2.0 \\
2.0 \\
2.1 \\
2.0\end{array}$ & $\begin{array}{l}1.8 \\
1.8 \\
1.8 \\
1.8 \\
1.8\end{array}$ & $\begin{array}{l}1.1 \\
1.1 \\
1.1 \\
1.1 \\
2.0\end{array}$ & $\begin{array}{l}1.05 \\
1.05 \\
1.5 \\
1.5 \\
1.5\end{array}$ & $\begin{array}{l}1.1 \\
1.1 \\
1.1 \\
1.1 \\
1.0\end{array}$ & $\begin{array}{l}1.2 \\
1.2 \\
1.2 \\
1.1 \\
1.1\end{array}$ & $\begin{array}{l}1.3 \\
1.2 \\
1.3 \\
1.3 \\
1.3\end{array}$ & $\begin{array}{l}3.15 \\
3.1 \\
3.1 \\
3.0 \\
\mathbf{3 . 0}\end{array}$ \\
\hline
\end{tabular}


Daily gage height, in feet, of Au Sable River at Bamfield, Mich., for 1906-Continued.

\begin{tabular}{|c|c|c|c|c|c|c|c|c|c|c|c|c|}
\hline Day. & Jan. & Feb. & Mar. & Apr. & May. & June. & July. & Aug. & Sept. & Oct. & Nov. & Dec. \\
\hline $\begin{array}{l}14 \ldots \\
15 \ldots\end{array}$ & $\begin{array}{l}0.9 \\
0.9 \\
0.9 \\
0.9 \\
1.0\end{array}$ & $\begin{array}{l}2.4 \\
2.4 \\
2.4 \\
2.4 \\
2.3\end{array}$ & $\begin{array}{l}1.4 \\
1.4 \\
1.3 \\
1.3 \\
1.2\end{array}$ & $\begin{array}{l}3.9 \\
3.45 \\
3.45 \\
3.65 \\
3.65\end{array}$ & $\begin{array}{l}2.0 \\
1.95 \\
2.05 \\
2.0 \\
2.0\end{array}$ & $\begin{array}{l}1.8 \\
1.8 \\
1.7 \\
1.5 \\
1.5\end{array}$ & $\begin{array}{l}1.9 \\
1.4 \\
1.4 \\
1.4 \\
1.9\end{array}$ & $\begin{array}{l}1.5 \\
1.4 \\
1.4 \\
1.3 \\
1.3\end{array}$ & $\begin{array}{l}1.0 \\
1.0 \\
1.0 \\
1.1 \\
1.0\end{array}$ & $\begin{array}{l}1.1 \\
1.1 \\
1.1 \\
1.1 \\
1.1\end{array}$ & $\begin{array}{l}1.2 \\
1.3 \\
1.2 \\
1.3 \\
1.3\end{array}$ & $\begin{array}{l}3.1 \\
3.0 \\
2.9 \\
2.8 \\
2.8\end{array}$ \\
\hline & $\begin{array}{l}1.1 \\
1.1 \\
1.1 \\
1.0 \\
1.1\end{array}$ & $\begin{array}{l}2.2 \\
2.0 \\
2.2 \\
2.6 \\
2.7\end{array}$ & $\begin{array}{l}1.2 \\
1.2 \\
1.1 \\
1.1 \\
1.2\end{array}$ & $\begin{array}{l}3.45 \\
3.0 \\
3.05 \\
2.5 \\
2.5\end{array}$ & $\begin{array}{l}2.0 \\
2.1 \\
1.9 \\
1.9 \\
1.9\end{array}$ & $\begin{array}{l}1.5 \\
2.3 \\
2.3 \\
2.1 \\
2.1\end{array}$ & $\begin{array}{l}1.9 \\
1.9 \\
2.0 \\
1.5 \\
1.5\end{array}$ & $\begin{array}{l}1.1 \\
1.1 \\
1.1 \\
1.1 \\
1.1\end{array}$ & $\begin{array}{l}1.0 \\
1.0 \\
1.0 \\
1.0 \\
1.0\end{array}$ & $\begin{array}{l}1.1 \\
1.2 \\
1.4 \\
1.5 \\
1.4\end{array}$ & $\begin{array}{l}1.35 \\
1.55 \\
1.85 \\
2.5 \\
2.7\end{array}$ & $\begin{array}{l}2.8 \\
2.8 \\
2.6 \\
2.5 \\
2.6\end{array}$ \\
\hline $\begin{array}{l}24 \ldots \\
25 \ldots\end{array}$ & $\begin{array}{l}1.3 \\
1.4 \\
2.4 \\
2.75 \\
2.2\end{array}$ & $\begin{array}{l}2.7 \\
2.8 \\
2.8 \\
2.8 \\
3.0\end{array}$ & $\begin{array}{l}1.2 \\
1.2 \\
1.2 \\
1.2 \\
1.4\end{array}$ & $\begin{array}{l}2.7 \\
2.7 \\
2.65 \\
2.55 \\
2.45\end{array}$ & $\begin{array}{l}1.9 \\
1.9 \\
1.9 \\
1.9 \\
2.0\end{array}$ & $\begin{array}{l}2.0 \\
1.9 \\
1.9 \\
1.9 \\
1.95\end{array}$ & $\begin{array}{l}1.5 \\
1.4 \\
1.2 \\
1.2 \\
1.1\end{array}$ & $\begin{array}{l}1.3 \\
1.3 \\
1.2 \\
1.1 \\
1.2\end{array}$ & $\begin{array}{l}1.0 \\
1.0 \\
1.0 \\
1.0 \\
1.0\end{array}$ & $\begin{array}{l}1.3 \\
1.3 \\
1.3 \\
1.2 \\
1.3\end{array}$ & $\begin{array}{l}2.75 \\
2.8 \\
2.7 \\
2.7 \\
2.6\end{array}$ & $\begin{array}{l}3.0 \\
3.5 \\
4.1 \\
4.35 \\
5.0\end{array}$ \\
\hline $\begin{array}{l}29 \ldots \\
30 \ldots \ldots \\
31 \ldots \ldots \\
\end{array}$ & $\begin{array}{l}2.3 \\
2.0 \\
1.55 \\
1.6 \\
1.6 \\
1.6\end{array}$ & $\begin{array}{l}2.8 \\
2.0 \\
1.9\end{array}$ & $\begin{array}{l}1.5 \\
1.8 \\
1.9 \\
1.7 \\
2.0 \\
2.5\end{array}$ & $\begin{array}{l}2.45 \\
2.0 \\
2.0 \\
2.2 \\
1.9\end{array}$ & $\begin{array}{l}1.9 \\
1.9 \\
1.9 \\
1.9 \\
1.9 \\
1.9\end{array}$ & $\begin{array}{l}2.0 \\
2.0 \\
2.2 \\
2.0 \\
2.0\end{array}$ & $\begin{array}{l}1.1 \\
1.1 \\
1.4 \\
1.5 \\
2.2 \\
1.5\end{array}$ & $\begin{array}{l}1.2 \\
1.4 \\
1.2 \\
1.1 \\
1.1 \\
1.1\end{array}$ & $\begin{array}{l}1.0 \\
1.0 \\
1.0 \\
1.1 \\
1.2\end{array}$ & $\begin{array}{l}1.2 \\
1.2 \\
1.1 \\
1.2 \\
1.0 \\
1.0\end{array}$ & $\begin{array}{l}2.6 \\
2.55 \\
2.65 \\
2.65 \\
2.8\end{array}$ & $\begin{array}{l}5.0 \\
5.0 \\
4.8 \\
4.2 \\
4.1 \\
2.85\end{array}$ \\
\hline
\end{tabular}

Rating table for Au Sable River at Bamfiela, Mich., for 1906.

\begin{tabular}{|c|r||r|r||r|r|r|r|}
\hline $\begin{array}{c}\text { Gage } \\
\text { height. }\end{array}$ & $\begin{array}{c}\text { Dis- } \\
\text { charge. }\end{array}$ & $\begin{array}{c}\text { Gage } \\
\text { height. }\end{array}$ & $\begin{array}{c}\text { Dis- } \\
\text { charge. }\end{array}$ & $\begin{array}{c}\text { Gage } \\
\text { height. }\end{array}$ & $\begin{array}{c}\text { Dis- } \\
\text { charge. }\end{array}$ & $\begin{array}{c}\text { Gage } \\
\text { height. }\end{array}$ & $\begin{array}{c}\text { Dis- } \\
\text { charge. }\end{array}$ \\
\hline Feet. & Sec.-ft. & Feet. & Sec.-ft. & Feet. & Sec.ft. & Feet. & Sec. ft. \\
0.90 & 1,050 & 1.70 & 1,460 & 2.50 & 1,960 & 3.60 & 2,810 \\
1.00 & 1,100 & 1.80 & 1,520 & 2.60 & 2,040 & 3.80 & 2,970 \\
1.10 & 1,140 & 1.90 & 1,570 & 2.70 & 2,110 & 4.00 & 3,130 \\
1.20 & 1,200 & 2.00 & 1,630 & 2.80 & 2,190 & 4.20 & 3,300 \\
1.30 & 1,240 & 2.10 & 1,700 & 2.90 & 2,260 & 4.40 & 3,480 \\
1.40 & 1,300 & 2.20 & 1,760 & 3.00 & 2,340 & 4.60 & 3,650 \\
1.50 & 1,340 & 2.30 & 1,830 & 3.20 & 2,490 & 4.80 & 3,840 \\
1.60 & 1,400 & 2.40 & 1,900 & 3.40 & 2,650 & 5.00 & 4,020 \\
\hline
\end{tabular}

Note.-The above table is applicable only for open-channel conditions. It is based on discharge measurements made during 1902-1905, and is well defined below gage height 3.5 feet.

Monthly discharge of Au Sable River at Bamfield, Mich., for 1906.

[Drainage area, 1,420 square miles.]

\begin{tabular}{|c|c|c|c|c|c|}
\hline \multirow[b]{2}{*}{ Month. } & \multicolumn{3}{|c|}{ Discharge in second-feet. } & \multicolumn{2}{|c|}{ Run-off. } \\
\hline & Maximum. & Minimum. & Mean. & $\begin{array}{l}\text { Sec.-ft.per } \\
\text { sq. mile. }\end{array}$ & $\begin{array}{l}\text { Depth in } \\
\text { inches. }\end{array}$ \\
\hline 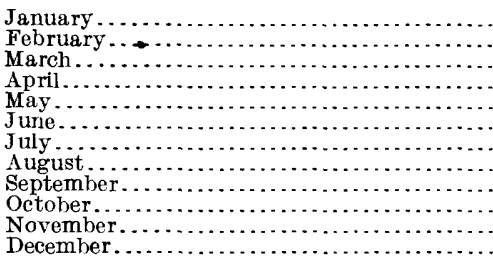 & $\begin{array}{l}2,150 \\
2,340 \\
1,960 \\
3,050 \\
1,700 \\
1,830 \\
1,760 \\
1,340 \\
1,200 \\
1,340 \\
2,190 \\
4,020\end{array}$ & $\begin{array}{l}1,050 \\
1,300 \\
1,140 \\
1,570 \\
1,570 \\
1,340 \\
1,140 \\
1,120 \\
1,100 \\
1,100 \\
1,140 \\
1,960\end{array}$ & $\begin{array}{l}1,270 \\
1,850 \\
1,350 \\
2,280 \\
1,610 \\
1,570 \\
1,320 \\
1,210 \\
1,120 \\
1,180 \\
1,580 \\
2,660\end{array}$ & $\begin{array}{l}0.894 \\
1.30 \\
.951 \\
1.61 \\
1.13 \\
1.11 \\
.930 \\
.852 \\
.789 \\
.831 \\
1.11 \\
1.87\end{array}$ & $\begin{array}{r}1.03 \\
1.35 \\
1.10 \\
1.80 \\
1.30 \\
1.24 \\
1.07 \\
.98 \\
.88 \\
.96 \\
1.24 \\
2.16\end{array}$ \\
\hline The year. & 4,020 & 1,050 & 1,580 & 1.11 & 15.11 \\
\hline
\end{tabular}

Note.-Values are rated as excellent except in February, the figures for which are probably considerably in excess of the true flow on account of ice conditions. 


\section{RIFLE RIVER BASIN.}

\section{DESCRIPTION OF BASIN.}

Rifle River rises in the vicinity of Rose City, in northern Ogemaw County, flows southward and southeastward, and empties into Saginaw Bay about 5 miles below Omer, Arenac County. Its basin, covering about 385 square miles, is long and narrow, having a width of about 3 miles at the mouth of the stream. The basin contains numerous small glacial lakes, but there is no controlled storage and a very small percentage of natural water surface. Ramifying tributaries at the headwaters give the stream a relatively large volume at the entrance of West Branch, in T. 21 N., R. 3 E. The region is wild and the stream is undeveloped, but it is being exploited with a view to the transmission of electric power to Saginaw and Bay City.

\section{RIFLE RIVER NEAR STERLING, MICH.}

This station was established November 14, 1905. It is located near Sterling, at Meeker's bridge, in sec. 5, T. 19 N., R. 5 E., and is about 4 miles upstream from Omer, where a gaging station was formerly maintained. The conditions at this station and the bench marks are described in Water-Supply Paper No. 170, page 40.

A measurement was made June 18, 1906, by Horton and Covert, with the following results:

Width, 51 feet; area, 140 square feet; gage height, 1.70 feet; discharge, 262 secondfeet.

Danly gage height, in feet, of Rifle River near Sterling, Mich., for 1906.

\begin{tabular}{|c|c|c|c|c|c|c|c|c|c|c|c|c|}
\hline Day. & Jan. & Feb. & Mar. & Apr. & lay. & June. & July. & Iug. & Sept. & Oct. & Nov. & Dec. \\
\hline $\begin{array}{l}1 . \\
2 . \\
3 . \\
4 . \\
5 .\end{array}$ & & $\begin{array}{l}3.35 \\
2.85 \\
3.65 \\
3.70 \\
3.82\end{array}$ & & & & & & 1.39 & $\begin{array}{l}1.3 \\
1.3\end{array}$ & & $\begin{array}{l}1.85 \\
1.77 \\
1.70 \\
1.66 \\
1.70\end{array}$ & $\begin{array}{l}2.8 \\
2.5 \\
2.3 \\
1.98 \\
2.08\end{array}$ \\
\hline $\begin{array}{l}6 . \\
7 . \\
8 . \\
9 .\end{array}$ & & & & & & & & $\begin{array}{l}1.41 \\
1.38 \\
1.36\end{array}$ & & & & $\begin{array}{l}2.1 \\
2.4 \\
3.3 \\
3.6 \\
3.7\end{array}$ \\
\hline & & $\begin{array}{l}3.22 \\
3.31 \\
3.48 \\
3.35 \\
3.34\end{array}$ & & & & $\begin{array}{l}2.32 \\
1.71 \\
1.66 \\
1.65 \\
1.60\end{array}$ & & $\begin{array}{l}1.31 \\
1.29 \\
1.26 \\
1.24 \\
1.22\end{array}$ & $\begin{array}{l}1.26 \\
1.23 \\
1.32 \\
1.26 \\
1.24\end{array}$ & & 1. 58 & $\begin{array}{l}3.4 \\
3.1 \\
3.10\end{array}$ \\
\hline & & $\begin{array}{l}\text { 3. } 38 \\
3.42 \\
3.50 \\
3.50 \\
3.60\end{array}$ & & & & $\begin{array}{l}\text { 1. } 72 \\
\text { 1. } 69\end{array}$ & $\begin{array}{l}1.55 \\
1.50\end{array}$ & $\begin{array}{l}1.25 \\
1.22 \\
1.21 \\
1.26 \\
1.45\end{array}$ & $\begin{array}{l}1.33 \\
1.31 \\
1.24 \\
1.23 \\
1.24\end{array}$ & & 2. 26 & $\begin{array}{l}2.8 \\
2.5 \\
2.5 \\
2.3 \\
2.3\end{array}$ \\
\hline 3. & $\begin{array}{l}3.50 \\
5.25 \\
6.20 \\
5.20 \\
4.60\end{array}$ & $\begin{array}{l}4.5 \\
4.5 \\
4.4 \\
5 . \\
6.6\end{array}$ & $\begin{array}{l}\text { J. } 40 \\
3.45 \\
3.50 \\
3.45 \\
3.34\end{array}$ & $\begin{array}{l}3 . \\
3.0 \\
3.2 \\
3.0 \\
2.9\end{array}$ & $\begin{array}{l}2 . \\
2 . \\
2 . \\
2 . \\
1 .\end{array}$ & $\begin{array}{l}1.70 \\
1.72 \\
1.70 \\
1.61 \\
1.54\end{array}$ & $\begin{array}{l}1.60 \\
1.55 \\
1.51 \\
1.48 \\
1.38\end{array}$ & $\begin{array}{l}1.7 \\
1.6 \\
1.8 \\
2.1 \\
1.7\end{array}$ & $\begin{array}{l}1.31 \\
1.45 \\
1.49 \\
1.47 \\
1.32\end{array}$ & $\begin{array}{l}1.64 \\
1.54 \\
1.64 \\
2.01\end{array}$ & $\begin{array}{l}3.75 \\
3.65 \\
3.00 \\
2.55\end{array}$ & $\begin{array}{l}2.58 \\
2.54 \\
2.32 \\
2.18 \\
2.25\end{array}$ \\
\hline
\end{tabular}


Daily gage height, in feet, of Rifle Rixer near Sterling, Mich., for 1906-Continued.

\begin{tabular}{|c|c|c|c|c|c|c|c|c|c|c|c|c|}
\hline Day. & Jan. & Feb. & Mar. & Apr. & May. & June. & July. & Aug. & Sept. & Oct. & Nov. & Dec. \\
\hline $\begin{array}{l}26 \ldots \\
27 \ldots \ldots \\
28 \ldots \ldots \\
29 \ldots \ldots \\
30 \ldots \ldots \\
31 \ldots \ldots\end{array}$ & $\begin{array}{l}4.32 \\
4.12 \\
4.08 \\
3.78 \\
3.68 \\
3.58\end{array}$ & $\begin{array}{l}6.65 \\
5.90 \\
5.44\end{array}$ & $\begin{array}{l}3.90 \\
5.92 \\
5.84 \\
6.40 \\
679 \\
7.20\end{array}$ & $\begin{array}{l}2.74 \\
2.53 \\
2.44 \\
2.62 \\
2.52\end{array}$ & $\begin{array}{l}2.08 \\
2.18 \\
2.15 \\
1.96 \\
1.91 \\
1.90\end{array}$ & $\begin{array}{l}1.56 \\
2.15 \\
2.65 \\
2.75 \\
2.50\end{array}$ & $\begin{array}{l}1.30 \\
1.37 \\
1.50 \\
1.52 \\
1.58 \\
1.51\end{array}$ & $\begin{array}{l}1.78 \\
2.04 \\
1.80 \\
1.64 \\
1.48 \\
1.41\end{array}$ & $\begin{array}{l}1.27 \\
1.32 \\
1.27 \\
1.90 \\
2.30\end{array}$ & $\begin{array}{l}2.05 \\
2.22 \\
2.40 \\
2.29 \\
2.15 \\
2.00\end{array}$ & $\begin{array}{l}3.48 \\
5.14 \\
4.14 \\
3.55 \\
3.10\end{array}$ & $\begin{array}{l}2.42 \\
2.47 \\
2.36 \\
2.41 \\
2.45 \\
4.08\end{array}$ \\
\hline
\end{tabular}

Note.-The following ice conditions prevailed during 1906: January 15, ice along both shores, open channel in midstream above and below gage; January 31 , ice along both shores from 4 to 10 inches thick, channel open; February 15, river frozen at gage, open above and below, ice 12 inches thick; February 28 , river frozen at gage, open above and below, ice 10 inches thick; March 15, river frozen at gage, small hole open above and below the section, ice 12 inches thick; March 21 , ice all gone.

\section{SAGINAW RIVER BASIN.}

\section{DESCRIPTION OF BASIN.}

Three streams--Tittabawassee, Shiawassee, and Cass riversunite near Saginaw to form Saginaw River, the combined catchment areas receiving the drainage from a crescent-shaped region of about 6,000 square miles surrounding Saginaw Bay.

Tittabawassee River, the northernmost of the three, drains a relatively flat region. From railroad profiles it is estimated that the fall of the stream from Highwood to its mouth, a distance of about 50 miles along the river, is 140 feet.

\section{TItTABawassee RIVER AT FREELAND, MICH.}

This station was established August 22, 1903, discontinued August 3,1906 , and reestablished October 28, 1906. It is located at the Freeland highway bridge, 10 miles northwest of Saginaw, in sec. 21, T. 13 N., R. 3 E., one-half mile from Freeland. The conditions at this station and the bench marks are described in Water-Supply Paper No. 170 , page 42 , where are given also references to publications that contain data for previous years.

Discharge measurements of Tittabawassee Rver at Freeland, Mich., in 1906.

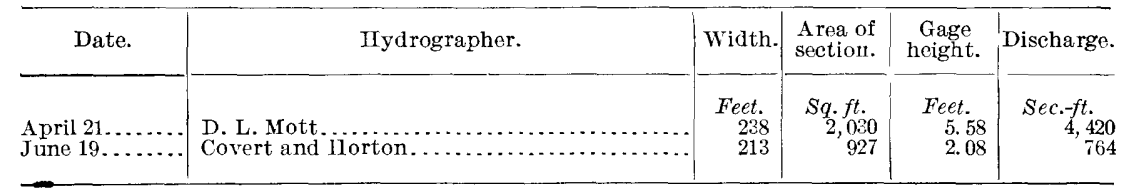

Daily yage height, in feet, of Tittabawassee River at Freeland, Mich., for 1906.

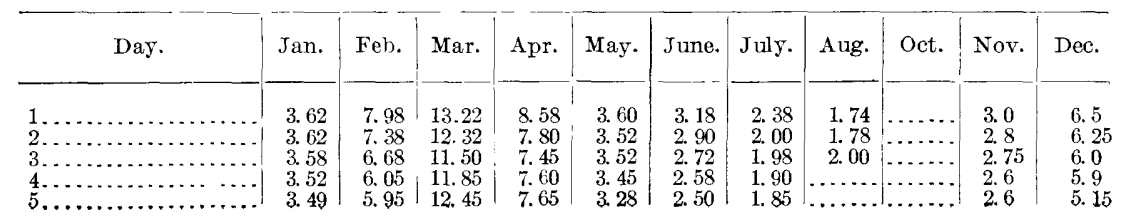


Daily gage height, in feet, of Tittabauasse River at Freeland, Mich., in 1906-Cont'd.

\begin{tabular}{|c|c|c|c|c|c|c|c|c|c|c|c|}
\hline Day. & Jan. & Feb. & Mar. & Apr. & May. & June. & July. & Aug. & Oct. & Nov. & Dec. \\
\hline $\begin{array}{r}6 \ldots \\
7 \ldots \\
8 \ldots \\
9 \ldots \\
10 \ldots\end{array}$ & $\begin{array}{l}\text { 3. } 42 \\
\text { 3. } 32 \\
\text { 3. } 29 \\
\text { 3. } 25 \\
\text { 3. } 22\end{array}$ & $\begin{array}{l}5.82 \\
5.78 \\
5.65 \\
5.60 \\
5.48\end{array}$ & $\begin{array}{l}12.20 \\
11.68 \\
11.22 \\
11.00 \\
10.95\end{array}$ & $\begin{array}{r}7.48 \\
6.02 \\
6.52 \\
7.55 \\
10.43\end{array}$ & $\begin{array}{l}\text { 3. } 12 \\
\text { 3. } 00 \\
\text { 2. } 88 \\
\text { 3. } 30 \\
\text { 3. } 22\end{array}$ & $\begin{array}{l}2.52 \\
2.52 \\
2.62 \\
2.75 \\
2.88\end{array}$ & $\begin{array}{l}1.90 \\
1.95 \\
1.82 \\
1.72 \\
1.68\end{array}$ & & & $\begin{array}{l}2.55 \\
2.5 \\
2.45 \\
2.4 \\
2.3\end{array}$ & $\begin{array}{l}4.85 \\
5.2 \\
5.6 \\
6.0 \\
6.2\end{array}$ \\
\hline $\begin{array}{l}11 \ldots \ldots \\
12 \ldots \ldots \\
13 \ldots \ldots \\
15, \ldots \ldots\end{array}$ & $\begin{array}{l}\text { 3. } 19 \\
\text { 3. } 15 \\
3.12 \\
3.10 \\
3.18\end{array}$ & $\begin{array}{l}\text { 5. } 18 \\
4.92 \\
4.60 \\
4.48 \\
4.40\end{array}$ & $\begin{array}{r}10.52 \\
10.05 \\
9.38 \\
8.92 \\
8.62\end{array}$ & $\begin{array}{r}10.60 \\
9.70 \\
8.85 \\
8.75 \\
10.50\end{array}$ & $\begin{array}{l}\text { 3. } 35 \\
\text { 3. } 48 \\
3.80 \\
5.20 \\
5.60\end{array}$ & $\begin{array}{l}2.75 \\
2.48 \\
2.28 \\
2.18 \\
2.08\end{array}$ & $\begin{array}{l}1.72 \\
1.62 \\
1.50 \\
1.55 \\
1.68\end{array}$ & & & $\begin{array}{l}2.2 \\
2.2 \\
2.15 \\
2.1 \\
2.1\end{array}$ & $\begin{array}{l}6.45 \\
6.8 \\
6.95 \\
7.2 \\
7.55\end{array}$ \\
\hline $\begin{array}{l}16 . . \\
17 . \\
18 \ldots \\
19 . \\
20 .\end{array}$ & $\begin{array}{l}\text { 3. } 40 \\
\text { 3. } 92 \\
\text { 4. } 58 \\
\text { 4. } 08 \\
\text { 4. } 22\end{array}$ & $\begin{array}{l}\text { 4. } 22 \\
\text { 4. } 00 \\
\text { 4. } 08 \\
\text { 4. } 18 \\
\text { 4. } 30\end{array}$ & $\begin{array}{l}8.22 \\
7.92 \\
7.62 \\
7.42 \\
7.30\end{array}$ & $\begin{array}{r}11.30 \\
10.00 \\
8.42 \\
7.30 \\
6.18\end{array}$ & $\begin{array}{l}5.15 \\
4.65 \\
4.32 \\
3.80 \\
3.10\end{array}$ & $\begin{array}{l}2.00 \\
\text { 2. } 00 \\
2.00 \\
\text { 1. } 75 \\
\text { 2. } 00\end{array}$ & $\begin{array}{l}\text { 1. } 75 \\
\text { 1. } 82 \\
\text { 1. } 92 \\
\text { 1. } 78 \\
1.68\end{array}$ & & & $\begin{array}{l}2.0 \\
2.0 \\
2.2 \\
3.8 \\
4.05\end{array}$ & $\begin{array}{l}7.8 \\
7.75 \\
7.0 \\
6.4 \\
5.3\end{array}$ \\
\hline $\begin{array}{l}21 . \\
22 . \\
23 . \\
24 .\end{array}$ & $\begin{array}{r}5.70 \\
10.08 \\
13.70 \\
14.62 \\
14.20\end{array}$ & $\begin{array}{r}6.40 \\
8.90 \\
9.95 \\
10.20 \\
11.05\end{array}$ & $\begin{array}{l}7.45 \\
7.12 \\
6.72 \\
6.38 \\
6.62\end{array}$ & $\begin{array}{l}\text { 5. } 62 \\
5.28 \\
5.02 \\
4.88 \\
\text { 4. } 65\end{array}$ & $\begin{array}{l}\text { 2. } 85 \\
\text { 2. } 70 \\
\text { 2. } 60 \\
\text { 2. } 78 \\
\text { 2. } 95\end{array}$ & $\begin{array}{l}2.00 \\
2.00 \\
2.00 \\
2.05 \\
2.00\end{array}$ & $\begin{array}{l}1.70 \\
1.65 \\
1.62 \\
1.58 \\
1.50\end{array}$ & & & $\begin{array}{l}5.3 \\
6.8 \\
7.1 \\
6.45 \\
5.2\end{array}$ & $\begin{array}{l}\text { 4. } 95 \\
4.5 \\
4.1 \\
\text { 3. } 9 \\
\text { 3. } 75\end{array}$ \\
\hline $\begin{array}{l}26 \ldots \\
27 \ldots \\
28 \ldots \\
29 \ldots \\
30 \ldots \\
31 \ldots\end{array}$ & $\begin{array}{r}13.65 \\
13.18 \\
12.30 \\
10.98 \\
9.90 \\
8.82\end{array}$ & $\begin{array}{l}14.90 \\
14.95 \\
13.90\end{array}$ & $\begin{array}{r}7.30 \\
10.65 \\
13.48 \\
12.20 \\
9.90 \\
9.18\end{array}$ & $\begin{array}{l}\text { 4. } 40 \\
\text { 4. } 32 \\
\text { 3. } 85 \\
\text { 3. } 82 \\
\text { 3. } 72\end{array}$ & $\begin{array}{l}\text { 3. } 38 \\
\text { 3. } 65 \\
3.88 \\
4.05 \\
\text { 3. } 82 \\
\text { 3. } 45\end{array}$ & $\begin{array}{l}2.00 \\
2.08 \\
2.12 \\
2.18 \\
2.10\end{array}$ & $\begin{array}{l}1.51 \\
1.50 \\
1.58 \\
1.75 \\
1.74 \\
1.70\end{array}$ & & $\begin{array}{l}2.6 \\
3.0 \\
3.2 \\
\text { 3. } 6\end{array}$ & $\begin{array}{l}5.85 \\
6.9 \\
7.0 \\
6.95 \\
6.9\end{array}$ & $\begin{array}{l}\text { 3. } 5 \\
\text { 3. } 45 \\
\text { 3. } 35 \\
\text { 3. } 3 \\
\text { 3. } 25 \\
6.0\end{array}$ \\
\hline
\end{tabular}

NotE.-Ice conditions probably affected the flow to some extent from January 21 to March 29. The high stages during this period were caused by ice jams. The ice passed out at noon, March 29 .

\section{LAKE ERIE DRAINAGE.}

\section{GENERAL FEATURES.}

That portion of the Lake Erie drainage basin that lies within the United States, exclusive of Lakes Superior, Michigan, and Huron, covers the northern third of Ohio, a small corner of northeastern Indiana, and a similar area in southeastern Michigan. South of the lake the drainage area is narrow, the divide lying in places scarcely 50 miles back from the lake shore. To the west the width of the area is greater, and the Maumee, which enters the lake near Toledo, is the largest stream of northern Ohio. The average altitude of the watershed above Lake Erie is 500 feet, but the head of the Maumee at Fort Wayne, Ind., is only 170 feet above the lake. The surface is level or gently rolling.

The principal streams are Huron and Raisin rivers, which enter the lake from the Michigan corner, and Maumee, Black, and Cuyahoga rivers, which enter from Ohio. Of these, the Maumee, formed by the junction of St. Marys and St. Joseph rivers at Fort Wayne, Ind., is the most important. 


\section{HURON RIVER BASIN.}

\section{DESCRIPTION OF BASIN.}

Huron River rises near the central part of Oakland County, Mich., flows southwestward, then southeastward, and is tributary to the west end of Lake Erie near the mouth of Detroit River. The Huron receives the drainage from an irregularly shaped basin having its greatest length parallel to and lying at a distance of 25 to 30 miles from Detroit River. This basin is connected with Lake Erie by a long, narrow valley, averaging 5 miles in width, extending from a point near Ypsilanti southeastward to Lake Erie, a distance of 28 miles. In this portion of its course a large part of the total fall of the river occurs. The conditions are thus nearly ideal for the development of water power, in that nearly the entire catchment area, all the large tributaries, and an extensive area affording lake and ground storage lie above the head of this narrow valley.

The northern portion of the main catchment area is rolling and its topography is complex. The stream flows through a series of lakes, and north of Dover the entire basin is largely composed of lakes and surrounding marshes. In the vicinity of Ann Arbor the topography is very rolling. The stream has here a broad, flat valley, bordered by abrupt hills ranging in height from 100 to 200 feet. The channel is tortuous and changeable. Numerous abandoned sections remain as bayous. Large springs issue from the morainal hills.

Below Ypsilanti the drainage basin is flat, the soil, comparatively heavy and impervious, is mostly under cultivation, and the groundwater level is controlled by numerous drain trenches.

\section{HURON RIVER AT DEXTER, MICH.}

This station was established September 1, 1904. It is located just above the highway bridge in the village of Dexter. The conditions at this station and the bench marks are described in Water-Supply Paper No. 170 , page 44 , where are given also references to publications that contain data for previous years.

Daily gage height, in feet, of ITuron River at Dexter, Mich., for 1906.

\begin{tabular}{|c|c|c|c|c|c|c|c|c|c|c|c|c|}
\hline Day. & Jan. & Feb. & Mar. & $\Lambda$ pr. & May. & June. & July. & Aug. & Sept. & Oct. & Nov. & Dec. \\
\hline $\begin{array}{l}1 \ldots \ldots \\
2 \ldots \\
3 \ldots \\
4 \ldots \\
5 \ldots\end{array}$ & $\begin{array}{l}\text { 1. } 40 \\
\text { 1. } 40 \\
\text { 1. } 45 \\
\text { 1. } 60 \\
\text { 1. } 52\end{array}$ & $\begin{array}{l}2.52 \\
2.42 \\
2.30 \\
2.12 \\
2.00\end{array}$ & $\begin{array}{l}1.60 \\
1.60 \\
2.05 \\
2.15 \\
1.98\end{array}$ & $\begin{array}{l}2.08 \\
2.40 \\
2.00 \\
1.95 \\
1.90\end{array}$ & $\begin{array}{l}1.40 \\
1.45 \\
1.42 \\
1.40 \\
1.35\end{array}$ & $\begin{array}{l}\text { 1. } 42 \\
1.32 \\
\text { 1. } 22 \\
1.20 \\
1.15\end{array}$ & $\begin{array}{r}0.90 \\
.90 \\
.90 \\
.90 \\
1.00\end{array}$ & $\begin{array}{l}1.25 \\
1.15 \\
1.10 \\
1.10 \\
1.08\end{array}$ & $\begin{array}{r}0.85 \\
.85 \\
.80 \\
.80 \\
.80\end{array}$ & $\begin{array}{r}0.90 \\
.85 \\
.85 \\
.85 \\
.95\end{array}$ & $\begin{array}{l}1.20 \\
1.20 \\
1.15 \\
1.15 \\
1.15\end{array}$ & $\begin{array}{l}\text { 1. } 40 \\
\text { 1. } 35 \\
\text { 1. } 35 \\
\text { 1. } 3 \\
1.35\end{array}$ \\
\hline $\begin{array}{r}6 \ldots \\
7 \ldots \\
8 \ldots \\
9 \ldots \\
10 \ldots\end{array}$ & $\begin{array}{l}\text { 1. } 45 \\
1.35 \\
1.40 \\
1.40 \\
1.40\end{array}$ & $\begin{array}{l}1.92 \\
1.82 \\
1.68 \\
1.58 \\
1.48\end{array}$ & $\begin{array}{l}1.90 \\
1.85 \\
1.80 \\
1.78 \\
1.75\end{array}$ & $\begin{array}{l}1.90 \\
1.85 \\
1.80 \\
2.10 \\
2.20\end{array}$ & $\begin{array}{l}1.35 \\
1.30 \\
1.25 \\
1.40 \\
1.35\end{array}$ & $\begin{array}{l}1.15 \\
1.25 \\
1.52 \\
1.75 \\
1.80\end{array}$ & $\begin{array}{l}.95 \\
.95 \\
.95 \\
.95 \\
.95\end{array}$ & $\begin{array}{l}1.08 \\
1.00 \\
1.00 \\
1.00 \\
1.05\end{array}$ & $\begin{array}{l}.75 \\
.75 \\
.70 \\
.70 \\
.70\end{array}$ & $\begin{array}{r}.95 \\
.95 \\
.95 \\
1.00 \\
1.00\end{array}$ & $\begin{array}{l}1.15 \\
1.15 \\
1.15 \\
1.12 \\
1.10\end{array}$ & $\begin{array}{l}1.80 \\
2.00 \\
1.98 \\
1.88 \\
1.82\end{array}$ \\
\hline
\end{tabular}


Daily gage height, in feet, of Huron River at Dexter, Mich., for 1906-Continued.

\begin{tabular}{|c|c|c|c|c|c|c|c|c|c|c|c|c|}
\hline Day. & Jan. & Feb. & Mar. & Apr. & May. & June. & July. & Aug. & Sept. & Oct. & Nov. & Dec. \\
\hline $\begin{array}{l}\ldots \ldots \\
\ldots \ldots \\
\cdots \\
\cdots\end{array}$ & $\begin{array}{l}1.35 \\
1.35 \\
1.30 \\
1.30 \\
1.35\end{array}$ & $\begin{array}{l}1.38 \\
1.35 \\
1.35 \\
1.35 \\
1.35\end{array}$ & $\begin{array}{l}1.72 \\
1.70 \\
1.70 \\
1.65 \\
1.60\end{array}$ & $\begin{array}{l}\text { 2. } 18 \\
\text { 2. } 10 \\
\text { 2. } 08 \\
\text { 2. } 30 \\
\text { 2. } 60\end{array}$ & $\begin{array}{l}1.30 \\
1.30 \\
1.30 \\
1.80 \\
2.20\end{array}$ & $\begin{array}{l}1.72 \\
1.62 \\
1.52 \\
1.42 \\
1.35\end{array}$ & $\begin{array}{r}0.95 \\
.95 \\
.95 \\
.95 \\
.92\end{array}$ & $\begin{array}{r}1.08 \\
1.00 \\
.95 \\
.90 \\
.90\end{array}$ & $\begin{array}{r}0.70 \\
.70 \\
.70 \\
.65 \\
.65\end{array}$ & $\begin{array}{l}1.00 \\
1.00 \\
1.00 \\
1.00 \\
1.00\end{array}$ & $\begin{array}{l}1.10 \\
1.05 \\
1.05 \\
1.05 \\
1.05\end{array}$ & $\begin{array}{l}\text { 1. } 80 \\
\text { 1. } 75 \\
\text { 1. } 75 \\
\text { 1. } 78 \\
1.85\end{array}$ \\
\hline $\begin{array}{l}\cdots \\
\ldots \ldots \ldots \\
\cdots \ldots \ldots \\
\ldots \ldots \ldots \ldots\end{array}$ & $\begin{array}{l}1.65 \\
1.58 \\
1.50 \\
1.50 \\
1.70\end{array}$ & $\begin{array}{l}1.32 \\
1.30 \\
1.28 \\
1.20 \\
1.20\end{array}$ & $\begin{array}{l}1.05 \\
1.52 \\
1.42 \\
1.42 \\
1.38\end{array}$ & $\begin{array}{l}2.55 \\
2.48 \\
2.32 \\
2.22 \\
2.12\end{array}$ & $\begin{array}{l}1.90 \\
1.70 \\
1.52 \\
1.50 \\
1.42\end{array}$ & $\begin{array}{l}1.30 \\
1.30 \\
1.30 \\
1.30 \\
1.30\end{array}$ & $\begin{array}{l}.90 \\
.90 \\
.85 \\
.85 \\
.80\end{array}$ & $\begin{array}{l}.90 \\
.85 \\
.82 \\
.80 \\
.80\end{array}$ & $\begin{array}{l}.65 \\
.65 \\
.65 \\
.65 \\
.65\end{array}$ & $\begin{array}{l}.95 \\
.95 \\
.95 \\
.95 \\
.95\end{array}$ & $\begin{array}{l}1.05 \\
1.08 \\
1.10 \\
1.10 \\
1.15\end{array}$ & $\begin{array}{l}1.80 \\
1.70 \\
1.55 \\
1.50 \\
1.50\end{array}$ \\
\hline $\begin{array}{l}21 \ldots \ldots \ldots \ldots \\
22 \ldots \ldots \ldots \ldots \\
23 \ldots \ldots \ldots \\
24 \ldots \ldots \ldots \ldots \\
25 \ldots \ldots \ldots\end{array}$ & $\begin{array}{l}\text { 2. } 50 \\
3.30 \\
\text { 3. } 40 \\
\text { 3. } 35 \\
3.25\end{array}$ & $\begin{array}{l}\text { 1. } 40 \\
\text { 1. } 40 \\
\text { 1. } 40 \\
\text { 1. } 45 \\
\text { 1. } 80\end{array}$ & $\begin{array}{l}1.32 \\
1.30 \\
1.30 \\
1.28 \\
1.25\end{array}$ & $\begin{array}{l}1.98 \\
1.88 \\
\text { 1. } 80 \\
\text { 1. } 75 \\
\text { 1. } 70\end{array}$ & $\begin{array}{l}1.32 \\
1.30 \\
1.35 \\
1.50 \\
1.42\end{array}$ & $\begin{array}{l}1.25 \\
1.20 \\
1.20 \\
1.15 \\
1.15\end{array}$ & $\begin{array}{l}.80 \\
.80 \\
.90 \\
.88 \\
.82\end{array}$ & $\begin{array}{l}.80 \\
.80 \\
.80 \\
.80 \\
.80\end{array}$ & $\begin{array}{l}.65 \\
.68 \\
.70 \\
.70 \\
.68\end{array}$ & $\begin{array}{r}.90 \\
.90 \\
.90 \\
.92 \\
1.00\end{array}$ & $\begin{array}{l}1.35 \\
1.50 \\
1.50 \\
1.50 \\
1.50\end{array}$ & $\begin{array}{l}\text { 1. } 45 \\
\text { 1. } 45 \\
\text { 1. } 45 \\
\text { 1. } 68 \\
1.58\end{array}$ \\
\hline $\begin{array}{l}27 \ldots \\
28 \ldots \\
29 \ldots \\
30 \ldots \\
31 \ldots\end{array}$ & $\begin{array}{l}3.05 \\
2.98 \\
2.92 \\
2.82 \\
2.72 \\
2.62\end{array}$ & $\begin{array}{r}1.80 \\
1.72 \\
1.65 \\
\ldots \ldots . .\end{array}$ & $\begin{array}{l}\text { 2. } 10 \\
\text { 2. } 48 \\
\text { 2. } 40 \\
\text { 2. } 28 \\
\text { 2. } 18\end{array}$ & $\begin{array}{r}1.68 \\
1.62 \\
1.58 \\
1.55 \\
1.45 \\
\ldots \ldots\end{array}$ & $\begin{array}{l}\text { 1. } 35 \\
\text { 1. } 40 \\
1.85 \\
1.88 \\
1.75 \\
1.55\end{array}$ & $\begin{array}{r}1.10 \\
1.10 \\
1.05 \\
1.00 \\
.95 \\
\cdots . .\end{array}$ & $\begin{array}{r}.80 \\
.75 \\
.75 \\
1.15 \\
1.48 \\
1.38\end{array}$ & $\begin{array}{l}.85 \\
.85 \\
.85 \\
.85 \\
.85 \\
.80\end{array}$ & $\begin{array}{r}.65 \\
.65 \\
.65 \\
.75 \\
.88\end{array}$ & $\begin{array}{l}1.02 \\
1.10 \\
1.15 \\
1.15 \\
1.15 \\
1.20\end{array}$ & $\begin{array}{c}1.50 \\
1.50 \\
1.48 \\
1.45 \\
1.42 \\
\ldots . . .\end{array}$ & $\begin{array}{l}\text { 1. } 48 \\
1.38 \\
\text { 1. } 35 \\
\text { 1. } 35 \\
1.42 \\
2.05\end{array}$ \\
\hline
\end{tabular}

HURON RIVER AT GEDDES, MICH.

A record of the depth of overflow at the dam and of the run of the water wheels in the adjacent electric plant has been maintained at Geddes by the Washtenaw Electric Company since February 1, 1904. The conditions at this station are described in Water-Supply Paper No. 170, page 45, where are given also references to publications that contain data for previous years.

Monthly discharge of IIuron River at Geddes, Mich., for 1906.

[Drainage area, 757 square miles.]

\begin{tabular}{|c|c|c|c|}
\hline \multirow[b]{2}{*}{ Month. } & \multirow{2}{*}{$\begin{array}{l}\text { Mean dis- } \\
\text { charge in } \\
\text { second-feet. }\end{array}$} & \multicolumn{2}{|c|}{ Run-off. } \\
\hline & & $\begin{array}{l}\text { Sec.-ft. per } \\
\text { sq. mile. }\end{array}$ & $\begin{array}{l}\text { Depth in } \\
\text { inches. }\end{array}$ \\
\hline 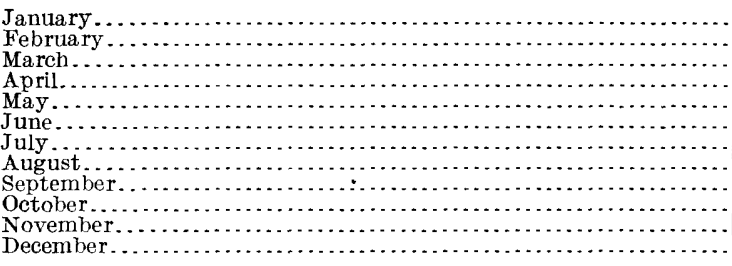 & $\begin{array}{l}686 \\
426 \\
515 \\
620 \\
454 \\
322 \\
148 \\
156 \\
83.6 \\
139 \\
272 \\
447\end{array}$ & $\begin{array}{r}0.906 \\
.563 \\
.680 \\
.819 \\
.600 \\
.425 \\
.196 \\
.206 \\
.110 \\
.184 \\
.359 \\
.591\end{array}$ & $\begin{array}{r}1.04 \\
.59 \\
.78 \\
.91 \\
.69 \\
.47 \\
.23 \\
.24 \\
.12 \\
.21 \\
.40 \\
.68\end{array}$ \\
\hline 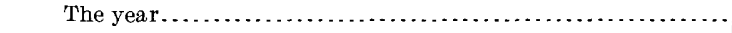 & 356 & .470 & 6.36 \\
\hline
\end{tabular}

HURON RIVER AT FLATROCK, MICH.

This station was established August 6, 1904. It is located at the highway bridge below Metler's dam at Flatrock, Mich., about 8 miles above the mouth of the stream. The conditions at this station and the bench marks are described in Water-Supply Paper No. 170, page 
47, where are given also references to publications that contain data for previous years.

Discharge measurements of Huron River at Flatrock, Mich., in 1906.

\begin{tabular}{|c|c|c|c|c|c|}
\hline Date. & Hydrographer. & Width. & $\begin{array}{l}\text { Area of } \\
\text { section. }\end{array}$ & $\begin{array}{l}\text { Gage } \\
\text { height. }\end{array}$ & $\begin{array}{l}\text { Dis- } \\
\text { charge. }\end{array}$ \\
\hline $\begin{array}{l}\text { April } 23 . \\
\text { June } 15 .\end{array}$ & $\begin{array}{l}\text { D. L. Mott } \ldots \ldots \ldots \ldots \ldots \ldots \ldots \ldots \\
\text { Horton and Covert } \ldots \ldots \ldots \ldots \ldots \ldots\end{array}$ & $\begin{array}{r}\text { Fect. } \\
100 \\
100\end{array}$ & $\begin{array}{r}S q \cdot f t . \\
430 \\
270\end{array}$ & $\begin{array}{l}\text { Feet. } \\
3.68 \\
2.22\end{array}$ & $\begin{array}{r}\text { Sec.-ft. } \\
944 \\
509\end{array}$ \\
\hline
\end{tabular}

Daily gage height, in feet, of Huron River at Flatrock, Mich., for 1906.

\begin{tabular}{|c|c|c|c|c|c|c|c|c|c|c|c|c|}
\hline Day. & Jan. & Feb. & Mar. & Apr. & Iay. & June. & July. & ug. & Sept. & Oet. & Nov. & Dec. \\
\hline $\begin{array}{l}1 . \\
2 . \\
3 . \\
4 .\end{array}$ & & $\begin{array}{l}4.85 \\
4.35 \\
5.65 \\
6.0 \\
5.7\end{array}$ & $\begin{array}{l}2.8 \\
3.0 \\
3.0 \\
4.4\end{array}$ & $\begin{array}{l}4.1 \\
4.0 \\
4.1 \\
3.9 \\
3.85\end{array}$ & $\begin{array}{l}2.8 \\
2.65 \\
2.7 \\
2.65 \\
2.7\end{array}$ & $\begin{array}{l}2.6 \\
2.25 \\
2.05 \\
1.75 \\
1.9\end{array}$ & $\begin{array}{l}1.25 \\
1.15 \\
1.0 \\
1.6 \\
1.45\end{array}$ & $\begin{array}{l}1.9 \\
1.65 \\
1.35 \\
1.35 \\
1.35\end{array}$ & $\begin{array}{l}1.0 \\
.7 \\
1.05 \\
.85 \\
1.15\end{array}$ & $\begin{array}{l}1.05 \\
1.1 \\
1.3 \\
1.0\end{array}$ & $\begin{array}{l}1.7 \\
1.8 \\
1.85 \\
1.65 \\
1.6\end{array}$ & $\begin{array}{l}2.3 \\
2.1 \\
2.05 \\
2.1 \\
1.9\end{array}$ \\
\hline $\begin{array}{r}6 \ldots \\
7 \ldots \\
8 \ldots \\
9 \ldots \\
10 \ldots\end{array}$ & & $\begin{array}{l}5.3 \\
5.1 \\
5.0 \\
4.85 \\
4.65\end{array}$ & $\begin{array}{l}4.0 \\
3.8 \\
3.6 \\
3.65 \\
3.55\end{array}$ & $\begin{array}{l}3.9 \\
3.8 \\
3.6 \\
3.8 \\
4.6\end{array}$ & $\begin{array}{l}2.4 \\
2.1 \\
2.35 \\
2.2 \\
2.35\end{array}$ & $\begin{array}{l}1.75 \\
1.75 \\
1.6 \\
3.15 \\
3.85\end{array}$ & $\begin{array}{l}2.25 \\
2.05 \\
1.5 \\
1.0 \\
1.5\end{array}$ & $\begin{array}{l}1.1 \\
1.55 \\
1.4 \\
1.35 \\
1.35\end{array}$ & $\begin{array}{l}1.1 \\
1.0 \\
.85 \\
.85 \\
.85\end{array}$ & $\begin{array}{l}1.1 \\
1.2 \\
1.3 \\
1.4 \\
1.3\end{array}$ & $\begin{array}{l}1.85 \\
1.75 \\
1.65 \\
1.55 \\
1.45\end{array}$ & $\begin{array}{l}3.45 \\
4.9 \\
4.8 \\
4.2 \\
3.85\end{array}$ \\
\hline 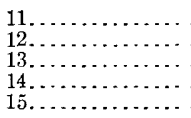 & & $\begin{array}{l}4.05 \\
3.6 \\
3.95 \\
3.6 \\
3.45\end{array}$ & $\begin{array}{l}3.35 \\
3.4 \\
3.15 \\
3.05\end{array}$ & $\begin{array}{l}4 . \\
4 . \\
4 .\end{array}$ & $\begin{array}{l}2.25 \\
2.15 \\
3.25 \\
4.5\end{array}$ & $\begin{array}{l}3.25 \\
2.95 \\
2.65 \\
2.35\end{array}$ & $\begin{array}{l}1.4 \\
1.25 \\
1.25 \\
1.05\end{array}$ & $\begin{array}{l}1.4 \\
1.3 \\
1.25 \\
1.5 \\
1.4\end{array}$ & $\begin{array}{l}.7 \\
1.0 \\
.75 \\
.7 \\
.8\end{array}$ & $\begin{array}{l}1.25 \\
1.35 \\
1.35 \\
1.15 \\
1.15\end{array}$ & $\begin{array}{l}1.6 \\
1.5 \\
1.5\end{array}$ & $\begin{array}{l}\text { Z.5 } \\
3.25 \\
3.15 \\
3.4 \\
3.75\end{array}$ \\
\hline $20 \ldots$ & 3.1 & $\begin{array}{l}3.0 \\
3.05 \\
3.0 \\
2.8 \\
3.3\end{array}$ & $\begin{array}{l}2.85 \\
2.7 \\
2.65 \\
2.45 \\
2.65\end{array}$ & $\begin{array}{l}5.3 \\
5.15 \\
4.65 \\
4.25 \\
4.05\end{array}$ & $\begin{array}{l}4.5 \\
4.35 \\
3.6 \\
3.0 \\
2.55\end{array}$ & $\begin{array}{l}2.2 \\
2.25 \\
2.05 \\
2.35 \\
2.0\end{array}$ & $\begin{array}{l}1.1 \\
1.15 \\
1.25 \\
1.15 \\
1.0\end{array}$ & $\begin{array}{l}1.0 \\
1.05 \\
.95 \\
1.0 \\
.95\end{array}$ & $\begin{array}{l}.7 \\
.65 \\
.6 \\
.85 \\
.75\end{array}$ & $\begin{array}{l}1.25 \\
1.2 \\
1.2 \\
1.25 \\
1.15\end{array}$ & $\begin{array}{l}1.45 \\
1.35 \\
1.4 \\
1.6 \\
1.75\end{array}$ & $\begin{array}{l}3.75 \\
3.45 \\
3.2 \\
2.65 \\
3.7\end{array}$ \\
\hline 24 & $\begin{array}{l}3.75 \\
5.85 \\
6.85 \\
7.05 \\
6.45\end{array}$ & $\begin{array}{l}3.3 \\
3.6 \\
3.5 \\
3.2 \\
3.0\end{array}$ & $\begin{array}{l}2.4 \\
2.4 \\
2.25 \\
1.85 \\
2.15\end{array}$ & $\begin{array}{l}3.9 \\
3.8 \\
3.6 \\
3.6 \\
3.3\end{array}$ & $\begin{array}{l}2.5 \\
2.1 \\
2.15 \\
2.3\end{array}$ & $\begin{array}{l}2.0 \\
1.85 \\
1.65 \\
1.7 \\
1.3\end{array}$ & \begin{tabular}{l|l}
1.1 & \\
.95 & \\
1.0 \\
1.25 \\
1.2
\end{tabular} & $\begin{array}{l}1.0 \\
1.15 \\
1.1 \\
1.2 \\
1.4\end{array}$ & $\begin{array}{l}.8 \\
.65 \\
.6 \\
.85 \\
.7\end{array}$ & $\begin{array}{l}1.1 \\
1.05 \\
1.2 \\
1.3 \\
1.35\end{array}$ & $\begin{array}{l}2.35 \\
3.0 \\
3.2 \\
3.0 \\
2.6\end{array}$ & $\begin{array}{l}5.15 \\
5.65 \\
4.1 \\
4.1 \\
4.3\end{array}$ \\
\hline $\begin{array}{l}29 . \\
30 .\end{array}$ & $\begin{array}{l}5.9 \\
5.55 \\
5.4 \\
5.3 \\
5.3 \\
5.05\end{array}$ & $\begin{array}{l}3.4 \\
3.75 \\
3.4\end{array}$ & $\begin{array}{l}2.05 \\
3.45 \\
5.1 \\
5.0 \\
4.85 \\
4.35\end{array}$ & $\begin{array}{l}3.25 \\
3.2 \\
2.9 \\
2.85 \\
2.7\end{array}$ & $\begin{array}{l}2.4 \\
2.25 \\
2.3 \\
3.3 \\
3.6 \\
3.05\end{array}$ & $\begin{array}{l}1.8 \\
1.65 \\
1.45 \\
1.25 \\
1.35\end{array}$ & $\begin{array}{l}1.05 \\
1.1 \\
1.15 \\
1.35 \\
1.8 \\
2.05\end{array}$ & $\begin{array}{l}1.1 \\
1.05 \\
1.1 \\
1.3 \\
1.15 \\
1.1\end{array}$ & $\begin{array}{l}.65 \\
.8 \\
.75 \\
.85 \\
1.05\end{array}$ & $\begin{array}{l}1.35 \\
1.3 \\
1.35 \\
1.5 \\
1.9 \\
1.75\end{array}$ & $\begin{array}{l}2.7 \\
2.65 \\
2.5 \\
2.35 \\
2.35\end{array}$ & $\begin{array}{l}4.2 \\
4.25 \\
4.15 \\
3.7 \\
3.5 \\
4.65 \\
.\end{array}$ \\
\hline
\end{tabular}

NotE.-The flow is somewhat affected by ice during the winter months; slush ice is noted on February 3 and anchor ice on March 21.

Rating table for Huron Rver at Flatrock, Mich., for 1906.

\begin{tabular}{|r|r|r|r|r|r|r|r|}
\hline $\begin{array}{r}\text { Gage } \\
\text { height. }\end{array}$ & $\begin{array}{c}\text { Dis- } \\
\text { charge. }\end{array}$ & $\begin{array}{c}\text { Gage } \\
\text { height. }\end{array}$ & $\begin{array}{c}\text { Dis- } \\
\text { charge. }\end{array}$ & $\begin{array}{c}\text { Gage } \\
\text { height. }\end{array}$ & $\begin{array}{c}\text { Dis- } \\
\text { charge. }\end{array}$ & $\begin{array}{c}\text { Gage } \\
\text { height. }\end{array}$ & $\begin{array}{c}\text { Dis- } \\
\text { charge. }\end{array}$ \\
\cline { 2 - 6 } Feet. & Sec.-ft. & Feet. & Sec.-ft. & Feet. & Sec.-ft. & F eet. & Sec.-ft. \\
0.60 & 141 & 1.90 & 401 & 3.20 & 722 & 5.00 & 1,261 \\
0.70 & 158 & 2.00 & 424 & 3.30 & 748 & 5.20 & 1,331 \\
0.80 & 176 & 2.10 & 447 & 3.40 & 774 & 5.40 & 1,403 \\
0.90 & 194 & 2.20 & 471 & 3.50 & 801 & 5.60 & 1,476 \\
1.00 & 213 & 2.30 & 495 & 3.60 & 828 & 5.80 & 1,550 \\
1.10 & 232 & 2.40 & 519 & 3.70 & 856 & 6.00 & 1,624 \\
1.20 & 252 & 2.50 & 543 & 3.80 & 884 & 6.20 & 1,699 \\
1.30 & 272 & 2.60 & 568 & 3.90 & 913 & 6.40 & 1,775 \\
1.40 & 293 & 2.70 & 593 & 4.00 & 942 & 6.60 & 1,852 \\
1.50 & 314 & 2.80 & 618 & 4.20 & 1,002 & 6.80 & 1,930 \\
1.60 & 335 & 2.90 & 644 & 4.40 & 1,064 & 7.00 & 2,010 \\
1.70 & 357 & 3.00 & 670 & 4.60 & 1,128 & 8.00 & 2,416 \\
1.80 & 379 & 3.10 & 696 & 4.80 & 1,194 & & \\
\hline
\end{tabular}

NoTE.-The above table is applicable only for open-channel conditions. It is based on discharge measurements made during 1904-1906, and is well defined between gage heights 0.3 foot and 2.6 feet.

IRR $206-07-4$ 
Monthly discharge of Huron River at Flatrock, Mich., for 1906.

\begin{tabular}{|c|c|c|c|}
\hline \multirow{2}{*}{ Month. } & \multicolumn{3}{|c|}{ Discharge in second-feet. } \\
\hline & Maximum. & Minimum. & Mean. \\
\hline January $(20-31) \ldots \ldots \ldots \ldots$ & 2,030 & 696 & 1,450 \\
\hline (1) & 1,620 & 618 & 967 \\
\hline 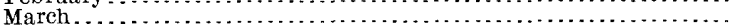 & 1,300 & 390 & 758 \\
\hline April & 1,370 & 593 & . \\
\hline May ........................... & 1,100 & 447 & 01 \\
\hline 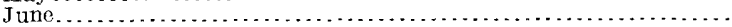 & 898 & 262 & 46 \\
\hline 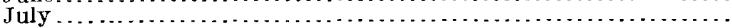 & 483 & 204 & 27 \\
\hline 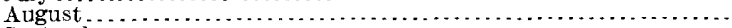 & 401 & 204 & 26 \\
\hline September. . . . . & 242 & 141 & 18 \\
\hline 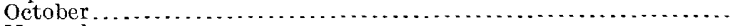 & 401 & 213 & \\
\hline 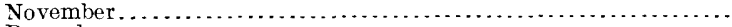 & 722 & 282 & \\
\hline 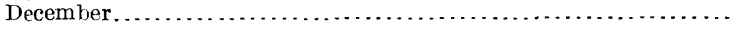 & 1,490 & 401 & \\
\hline
\end{tabular}

Note.-Values a re good.

\section{MAUMEE RIVER BASIN.}

DESCRIPTION OF BASIN.

Maumee River is formed at Fort Wayne, Ind., by the junction of St. Joseph and St. Marys rivers and flows northeastward into Lake Erie at Toledo. The chief tributaries are Auglaize and Tiffin rivers. The total drainage area is 6,723 square miles.

\section{MAUMEE RIVER NEAR SHERWOOD, OHIO.}

This station was established May 19, 1903, and was discontinued July 21, 1906. It is located at the highway bridge 2.5 miles south of Sherwood, Ohio, and 200 feet upstream from the Cincinnati Northern Railroad bridge. The conditions at this station and the bench marks are described in Water-Supply Paper No. 170, page 50, where are given also references to publications that contain data for previous years.

Discharge measurements of Maumee River near Sherwood, Ohı, in 1906.

\begin{tabular}{|c|c|c|c|c|c|}
\hline Date. & Hydrographer. & Width. & $\begin{array}{l}\text { A rea of } \\
\text { section. }\end{array}$ & $\begin{array}{c}\text { Gage } \\
\text { height. }\end{array}$ & $\begin{array}{c}\text { Dis- } \\
\text { charge. }\end{array}$ \\
\hline $\begin{array}{l}\text { February } 11 a \\
\text { March } 8 \ldots \ldots \\
\text { April } 5 \ldots \ldots \ldots \\
\text { May } 12 \ldots \ldots\end{array}$ & 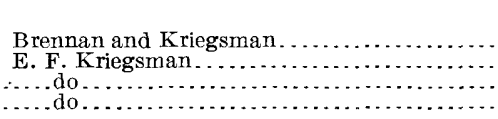 & $\begin{array}{r}\text { Feet. } \\
236 \\
248 \\
266 \\
242\end{array}$ & $\begin{array}{r}S q \cdot f t \\
597 \\
1,060 \\
1,540 \\
470\end{array}$ & $\begin{array}{l}\text { Feet. } \\
\quad 3.34 \\
\quad 4.57 \\
\quad 6.51 \\
\quad 2.30\end{array}$ & $\begin{array}{r}\text { Sec. } f t . \\
455 \\
1,92 \\
3,36 \\
48\end{array}$ \\
\hline
\end{tabular}

$a$ River entirely frozen over; average thickness of ice, 0.6 foot; gage height to top of ice, 3.39 feet.

Daily gage height, in feet, of Maumee River at Sherwood, Ohio, for 1906.

\begin{tabular}{|c|c|c|c|c|c|c|c|}
\hline Day. & Jan. & Feb. & Mar. & Apr. & May. & June. & July. \\
\hline 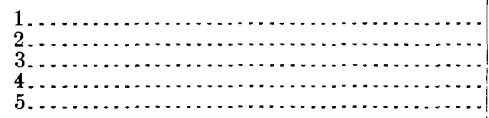 & $\begin{array}{l}4.4 \\
4.0 \\
3.72 \\
3.7 \\
4.2\end{array}$ & $\begin{array}{l}5.3 \\
5.2 \\
5.2 \\
5.3\end{array}$ & $\begin{array}{l}5.0 \\
3.8 \\
3.9 \\
5.3 \\
5.8\end{array}$ & $\begin{array}{r}10.5 \\
10.1 \\
9.5 \\
7.2 \\
6.5\end{array}$ & $\begin{array}{l}3.0 \\
2.9 \\
2.7 \\
2.7 \\
2.6\end{array}$ & $\begin{array}{l}2.6 \\
2.5 \\
2.4 \\
2.35 \\
2.3\end{array}$ & $\begin{array}{l}2.4 ! \\
2.4 ! \\
2.5 \\
2.6 \\
2.6\end{array}$ \\
\hline $\begin{array}{r}6 \ldots \ldots \ldots \\
7 \ldots \ldots \\
8 \ldots \ldots \ldots \\
9 \\
10 \ldots \ldots \ldots\end{array}$ & $\begin{array}{l}4.4 \\
4.6 \\
5.0 \\
5.4 \\
5.6\end{array}$ & . & $\begin{array}{l}5.6 \\
5.1 \\
4.6 \\
4.2 \\
4.1\end{array}$ & $\begin{array}{l}6.0 \\
5.6 \\
5.2 \\
5.2 \\
8.5\end{array}$ & $\begin{array}{l}2.6 \\
2.6 \\
2.5 \\
2.4 \\
2.4\end{array}$ & $\begin{array}{l}2.25 \\
2.2 \\
2.25 \\
2.4 \\
2.55\end{array}$ & $\begin{array}{l}2.5 \\
2.5 \\
2.5 \\
2.5 \\
2.7\end{array}$ \\
\hline
\end{tabular}


Daily gage height, in feet, of Maumee River at Sherwood, Ohio, for 1906-Continued.

\begin{tabular}{|c|c|c|c|c|c|c|c|}
\hline Day. & Jan. & Feb. & Mar. & Apr. & May. & June. & July. \\
\hline 15. & $\begin{array}{l}5.6 \\
5.6 \\
5.6 \\
5.6 \\
5.5\end{array}$ & $\begin{array}{r}\cdots \\
4.6\end{array}$ & $\begin{array}{l}4.0 \\
3.9 \\
3.8 \\
3.6 \\
3.3\end{array}$ & $\begin{array}{l}7.6 \\
6.4 \\
5.8 \\
6.3 \\
7.8\end{array}$ & $\begin{array}{l}2.35 \\
2.3 \\
2.25 \\
2.2 \\
2.2\end{array}$ & $\begin{array}{l}2.6 \\
4.2 \\
5.2 \\
4.8 \\
4.6\end{array}$ & $\begin{array}{l}3.55 \\
3.5 \\
3.3 \\
3.2 \\
3.1\end{array}$ \\
\hline $18 \ldots$ & $\begin{array}{l}5.4 \\
5.2 \\
5.1 \\
5.3 \\
6.2\end{array}$ & ?...... & $\begin{array}{l}3.2 \\
3.1 \\
3.1 \\
3.0 \\
3.0\end{array}$ & $\begin{array}{l}7.2 \\
6.9 \\
6.4 \\
5.9 \\
5.0\end{array}$ & $\begin{array}{l}2.15 \\
2.1 \\
2.1 \\
2.5 \\
2.5\end{array}$ & $\begin{array}{l}4.4 \\
4.0 \\
3.6 \\
3.35 \\
3.1\end{array}$ & $\begin{array}{l}3.0 \\
3.0 \\
3.0 \\
2.95 \\
2.9\end{array}$ \\
\hline $\begin{array}{l}23 . \\
24 . \\
25 .\end{array}$ & $\begin{array}{r}8.1 \\
9.0 \\
10.7 \\
10.1 \\
9.6\end{array}$ & $\begin{array}{l}\cdots \cdots \\
3.2 \\
3.3\end{array}$ & $\begin{array}{l}2.9 \\
2.9 \\
2.9 \\
2.8 \\
2.8\end{array}$ & $\begin{array}{l}4.4 \\
4.0 \\
3.6 \\
3.3 \\
3.4\end{array}$ & $\begin{array}{l}2.45 \\
2.3 \\
2.2 \\
2.15 \\
2.15\end{array}$ & $\begin{array}{l}\text { 3. } 0 \\
2.8 \\
3.2 \\
3.0 \\
2.85\end{array}$ & 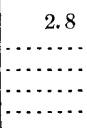 \\
\hline $\begin{array}{l}26 \ldots \ldots \\
27 \ldots \ldots \\
28 \ldots \ldots \\
29 \ldots \ldots \\
30 \ldots \ldots \\
31 \ldots \ldots\end{array}$ & $\begin{array}{l}9.0 \\
8.1 \\
7.3 \\
5.9 \\
5.5 \\
5.3\end{array}$ & $\begin{array}{r}3.3 \\
4.4 \\
5.3 \\
\ldots . . \\
\end{array}$ & $\begin{array}{l}2.8 \\
6.32 \\
12.8 \\
13.0 \\
11.6 \\
11.2\end{array}$ & $\begin{array}{l}4.3 \\
3.8 \\
3.4 \\
3.3 \\
3.2\end{array}$ & $\begin{array}{l}2.15 \\
2.15 \\
2.15 \\
2.2 \\
2.3 \\
2.65\end{array}$ & $\begin{array}{l}2.7 \\
2.6 \\
2.55 \\
2.5 \\
2.5\end{array}$ & 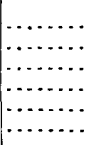 \\
\hline
\end{tabular}

NoтE.-The river was frozen January 9 to 19 and February 5 to 24 ; ice was about 0.5 foot thick February 15 to 19.

Rating table for Maumee Rvver near Sherwood, Ohio, for 1906.

\begin{tabular}{|c|r|r|r|r|r|r|r|}
\hline $\begin{array}{c}\text { Gage } \\
\text { height. }\end{array}$ & $\begin{array}{c}\text { Dis- } \\
\text { charge. }\end{array}$ & $\begin{array}{c}\text { Gage } \\
\text { height. }\end{array}$ & $\begin{array}{c}\text { Dis- } \\
\text { charge. }\end{array}$ & $\begin{array}{c}\text { Gage } \\
\text { height. }\end{array}$ & $\begin{array}{c}\text { Dis- } \\
\text { charge. }\end{array}$ & $\begin{array}{c}\text { Gage } \\
\text { height. }\end{array}$ & $\begin{array}{c}\text { Dis- } \\
\text { charge. }\end{array}$ \\
\hline Feet. & Sec.-ft. & Feet. & Sec.-ft. & Feet. & Sec.-ft. & Feet. & Sec.-ft. \\
2.10 & 370 & 3.40 & 1,120 & 4.70 & 2,000 & 7.00 & 3,770 \\
2.20 & 425 & 3.50 & 1,180 & 4.80 & 2,070 & 7.20 & 3,930 \\
2.30 & 480 & 3.60 & 1,240 & 4.90 & 2,140 & 7.40 & 4,090 \\
2.40 & 535 & 3.70 & 1,300 & 5.00 & 2,210 & 7.60 & 4,270 \\
2.50 & 590 & 3.80 & 1,370 & 5.20 & 2,350 & 7.80 & 4,450 \\
2.60 & 645 & 5.90 & 1,440 & 5.40 & 2,490 & 8.00 & 4,630 \\
2.70 & 700 & 4.00 & 1,510 & 5.60 & 2,650 & 9.00 & 5,530 \\
2.80 & 760 & 4.10 & 1,580 & 5.80 & 2,810 & 10.00 & 6,470 \\
2.90 & 820 & 4.20 & 1,650 & 6.00 & 2,970 & 11.00 & 7,470 \\
3.00 & 880 & 4.30 & 1,720 & 6.20 & 3,130 & 12.00 & 8,570 \\
3.10 & 940 & 4.40 & 1,790 & 6.40 & 3,290 & 13.00 & 9,680 \\
3.20 & 1,000 & 4.50 & 1,860 & 6.60 & 3,450 & & \\
3.30 & 1,060 & 4.60 & 1,930 & 6.80 & 3,610 & & \\
\hline
\end{tabular}

NoTE.-The above table is applicable only for open-channel conditions. It is based on three discharge measurements made during 1906, and the form of the 1905 curve. It is well defined below gage height 6.5 feet.

Monthly discharge of Maumee Rver near Sherwood, Ohio, for 1906.

[Drainage area, 2,190 square miles.]

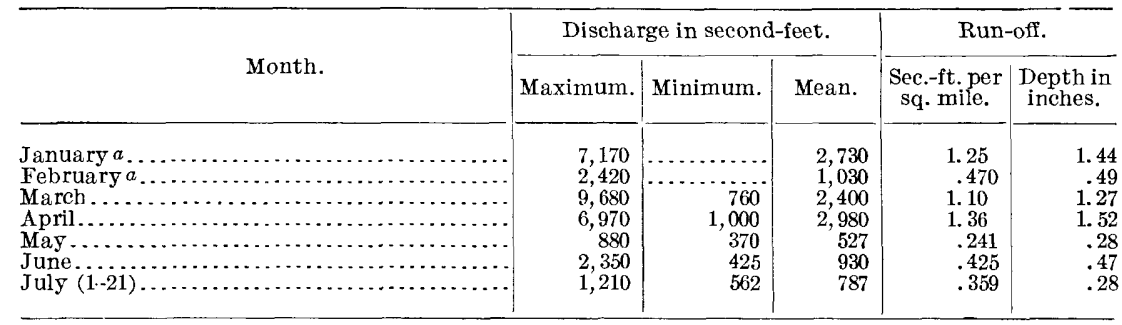

$a$ January and February corrected for effect of ice conditions.

Note.-Values are rated as follows: January and February, fair; March to July, good. 


\section{ST. JOSEPH RIVER AT FORT WAYNE, IND.}

This station was established March 20, 1905, and was discontinued July 20, 1906. It was located on the first highway bridge, about 1 mile above the junction with St. Marys River. The gage was read during 1906 by S. F. Mills. The conditions at this station and the bench marks are described in Water-Supply Paper No. 170, page 52.

Discharge measurements of St. Joseph River at Fort Wayne, Ind., in 1906.

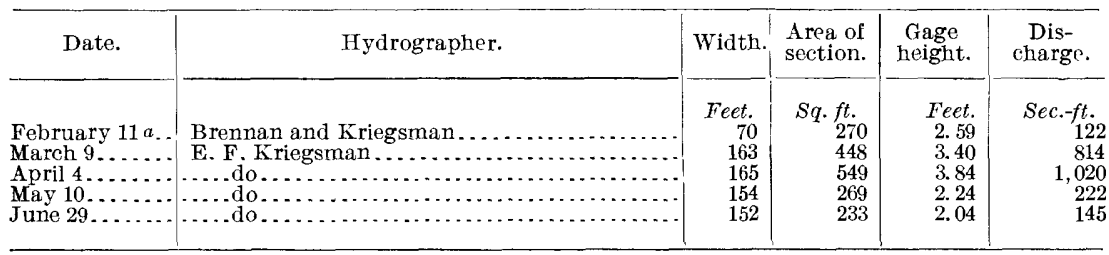

$a$ Ice along edges. The flow was diminished by about 65 per cent of the open-channel rating.

Daily gage height, in feet, of St. Joseph River at Fort Wayne, Ind., for 1906.

\begin{tabular}{|c|c|c|c|c|c|c|c|}
\hline Day. & Jan. & Feb. & Mar. & Apr. & May. & June. & July. \\
\hline $\begin{array}{l}1 \ldots \\
2 \ldots \\
3 \ldots \\
4 \ldots \\
5 \ldots\end{array}$ & $\begin{array}{l}3.0 \\
2.9 \\
2.75 \\
3.3 \\
3.6\end{array}$ & $\begin{array}{l}3.55 \\
3.25 \\
2.85 \\
2.7 \\
2.7\end{array}$ & $\begin{array}{l}\text { 3. } 05 \\
3.0 \\
3.5 \\
4.9 \\
4.75\end{array}$ & $\begin{array}{l}8.05 \\
6.9 \\
5.2 \\
4.85 \\
3.4\end{array}$ & $\begin{array}{l}2.45 \\
2.4 \\
2.35 \\
2.35 \\
2.5\end{array}$ & \begin{tabular}{l|l}
2.2 \\
2.1 \\
2.05 \\
2.0 \\
2.0
\end{tabular} & $\begin{array}{l}2.0 \\
2.0 \\
2.05 \\
2.0 \\
1.95\end{array}$ \\
\hline $\begin{array}{r}6 \\
7 \ldots \ldots \\
8 \\
9 \\
9 \\
10\end{array}$ & $\begin{array}{l}3.25 \\
3.3 \\
3.25 \\
3.05 \\
2.9\end{array}$ & $\begin{array}{l}3.1 \\
2.9 \\
2.8 \\
2.7 \\
2.6\end{array}$ & $\begin{array}{l}4.35 \\
4.05 \\
3.75 \\
3.4 \\
3.3\end{array}$ & $\begin{array}{l}3.45 \\
3.55 \\
3.15 \\
4.5 \\
5.05\end{array}$ & $\begin{array}{l}2.55 \\
2.4 \\
2.3 \\
2.25 \\
2.25\end{array}$ & $\begin{array}{l}2.0 \\
1.95 \\
1.95 \\
\text { 3. } 05 \\
4.55\end{array}$ & $\begin{array}{l}1.95 \\
1.8 \\
1.8 \\
1.8 \\
1.75\end{array}$ \\
\hline $\begin{array}{l}14 \ldots \\
15 \ldots\end{array}$ & $\begin{array}{l}2.85 \\
2.65 \\
2.55 \\
2.35 \\
2.3\end{array}$ & \begin{tabular}{l|}
2.4 \\
2.35 \\
2.15 \\
2.2 \\
2.5
\end{tabular} & $\begin{array}{l}3.35 \\
3.25 \\
3.05 \\
2.9 \\
2.85\end{array}$ & $\begin{array}{l}4.55 \\
4.05 \\
3.75 \\
3.9 \\
5.95\end{array}$ & \begin{tabular}{l|}
2.2 \\
2.15 \\
2.15 \\
2.1 \\
2.1
\end{tabular} & $\begin{array}{l}4.45 \\
4.15 \\
4.0 \\
3.95 \\
3.7\end{array}$ & $\begin{array}{l}2.4 \\
2.3 \\
2.1 \\
1.9 \\
1.9\end{array}$ \\
\hline $\begin{array}{l}16 \ldots \\
17 \ldots \\
18 \ldots \\
19 \ldots \\
20 \ldots\end{array}$ & $\begin{array}{l}2.55 \\
2.75 \\
2.75 \\
2.95 \\
2.75\end{array}$ & $\begin{array}{l}2.55 \\
2.55 \\
2.1 \\
2.05 \\
2.0\end{array}$ & $\begin{array}{l}2.75 \\
2.75 \\
2.45 \\
2.45 \\
2.3\end{array}$ & $\begin{array}{l}5.7 \\
5.0 \\
4.55 \\
4.1 \\
3.65\end{array}$ & $\begin{array}{l}2.1 \\
2.35 \\
2.65 \\
2.55 \\
2.3\end{array}$ & $\begin{array}{l}3.25 \\
3.0 \\
2.8 \\
2.55 \\
2.45\end{array}$ & $\begin{array}{l}2.3 \\
2.3 \\
2.3 \\
2.2 \\
2.2\end{array}$ \\
\hline $\begin{array}{l}21 . . \\
22 . \\
23 . \\
24 . \\
25 .\end{array}$ & $\begin{array}{l}4.1 \\
7.3 \\
8.0 \\
7.95 \\
7.1\end{array}$ & $\begin{array}{l}2.05 \\
2.2 \\
2.2 \\
2.3 \\
2.85\end{array}$ & $\begin{array}{l}2.6 \\
2.25 \\
2.45 \\
2.4 \\
2.4\end{array}$ & $\begin{array}{l}3.3 \\
3.0 \\
2.9 \\
2.75 \\
2.65\end{array}$ & $\begin{array}{l}2.25 \\
2.1 \\
2.05 \\
2.05 \\
2.0\end{array}$ & $\begin{array}{l}2.75 \\
2.8 \\
2.6 \\
2.35 \\
2.25\end{array}$ & 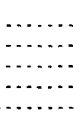 \\
\hline 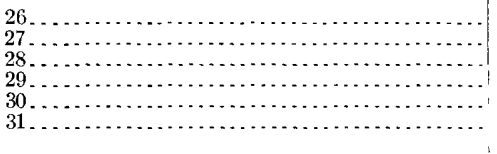 & $\begin{array}{l}6.45 \\
6.1 \\
5.2 \\
4.55 \\
4.0 \\
3.7\end{array}$ & $\begin{array}{l}3.55 \\
3.7 \\
3.25\end{array}$ & $\begin{array}{l}3.4 \\
7.7 \\
9.15 \\
8.55 \\
7.9 \\
8.65\end{array}$ & $\begin{array}{l}3.6 \\
3.0 \\
2.9 \\
2.75 \\
2.55\end{array}$ & $\begin{array}{l}2.0 \\
2.35 \\
2.75 \\
2.5 \\
2.35 \\
2.3\end{array}$ & $\begin{array}{l}2.2 \\
2.1 \\
2.05 \\
2.05 \\
2.1\end{array}$ & $\cdots$ \\
\hline
\end{tabular}

Note.-Flow affected by ice conditions during part of February. 
Rating table for St. Joseph Rvver at Fort Wayne, Ind., for 1906.

\begin{tabular}{|c|c|c|c|c|c|c|c|}
\hline $\begin{array}{l}\text { Gage } \\
\text { hoight. }\end{array}$ & $\begin{array}{c}\text { Dis- } \\
\text { charge. }\end{array}$ & $\begin{array}{l}\text { Gage } \\
\text { height. }\end{array}$ & $\begin{array}{c}\text { Dis- } \\
\text { charge. }\end{array}$ & $\begin{array}{c}\text { Gage } \\
\text { height. }\end{array}$ & $\begin{array}{c}\text { Dis- } \\
\text { charge. }\end{array}$ & $\begin{array}{c}\text { Gage } \\
\text { height. }\end{array}$ & $\begin{array}{c}\text { Dis- } \\
\text { charge. }\end{array}$ \\
\hline $\begin{array}{r}\text { Feet. } \\
1.80 \\
1.90 \\
2.00 \\
2.10 \\
2.20 \\
2.30 \\
2.40 \\
2.50 \\
2.60 \\
2.70 \\
2.80 \\
2.90 \\
3.00\end{array}$ & $\begin{array}{r}\text { Sec. } f t . \\
80 \\
105 \\
135 \\
165 \\
200 \\
240 \\
280 \\
325 \\
370 \\
420 \\
470 \\
525 \\
580\end{array}$ & $\begin{array}{r}\text { Feet. } \\
3.10 \\
3.20 \\
3.30 \\
3.40 \\
3.50 \\
3.60 \\
3.70 \\
3.80 \\
3.90 \\
4.00 \\
4.10 \\
4.20 \\
4.30\end{array}$ & $\begin{array}{r}\text { Sec.-ft. } \\
635 \\
695 \\
755 \\
815 \\
880 \\
945 \\
1,010 \\
1,080 \\
1,150 \\
1,220 \\
1,290 \\
1,365 \\
1,440\end{array}$ & $\begin{array}{r}\text { Feet. } \\
4.40 \\
4.50 \\
4.60 \\
4.70 \\
4.80 \\
4.90 \\
5.00 \\
5.20 \\
5.40 \\
6.60 \\
5.80 \\
6.00\end{array}$ & $\begin{array}{r}\text { Sec. }-f t . \\
1,515 \\
1,590 \\
1,670 \\
1, i 50 \\
1,830 \\
1,910 \\
2,000 \\
2,180 \\
2,365 \\
2,560 \\
2,760 \\
2,970\end{array}$ & $\begin{array}{r}\text { Feet. } \\
6.20 \\
6.40 \\
6.60 \\
6.80 \\
7.00 \\
7.20 \\
7.40 \\
7.60 \\
7.80 \\
8.00 \\
9.00 \\
10.00\end{array}$ & $\begin{array}{r}\text { Sec.-ft. } \\
3,190 \\
3,420 \\
3,660 \\
3,900 \\
4,150 \\
4,410 \\
4,670 \\
4,940 \\
5,220 \\
5,500 \\
7,000 \\
8,600\end{array}$ \\
\hline
\end{tabular}

NotE.-The above table is applicable only for open-channel condition. It is based on discharge measurements made during 1905-6, and is well defined between gage heights 2 feet and 6 feet.

Monthly discharge of St. Joseph River at Fort Wayne, Ind., for 1906.

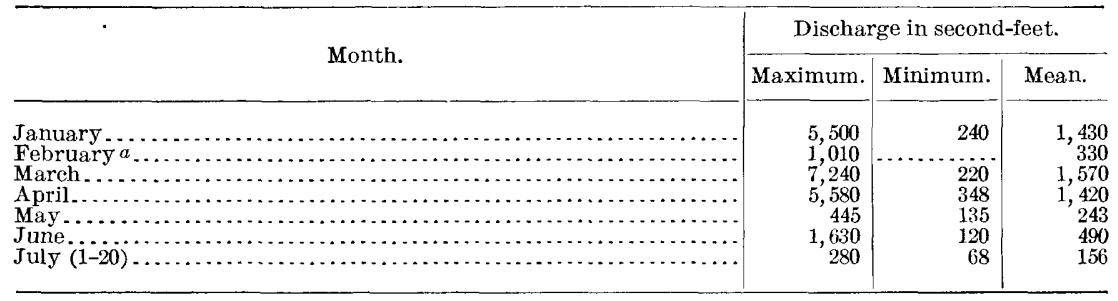

a Discharge corrected for effect of ice conditions.

Note.-Values are rated as follows: February, fair; remainder of period, excellent.

ST. MARYS RIVER AT FORT WAYNE, IND.

This station was established March 20, 1905, and was discontinued July 21, 1906. It was located on the Taylor Street Bridge, in Fort Wayne, about 2.5 miles above the junction of the stream with the St. Joseph. The conditions at this station and the bench marks are described in Water-Supply Paper No. 170, page 55.

Discharge measurements of St. Marys River at Fort Wayne, Ind., in 1905-6.

\begin{tabular}{|c|c|c|c|c|c|}
\hline Date. & Hydrographer. & Width. & $\begin{array}{l}\text { Area of } \\
\text { section. }\end{array}$ & $\begin{array}{c}\text { Gage } \\
\text { height. }\end{array}$ & $\begin{array}{c}\text { Dis- } \\
\text { charge. }\end{array}$ \\
\hline $\begin{array}{c}1905 . \\
\text { March } 20 \ldots\end{array}$ & Hanna and Clapp. & $\begin{array}{l}\text { Feet. } \\
120\end{array}$ & $s q . f t$. & $\begin{array}{l}\text { Feet. } \\
5.59\end{array}$ & $\begin{array}{c}\text { Sec. }-f t . \\
1,360\end{array}$ \\
\hline May $26 \ldots$ & M. S Brennan... & 104 & 199 & 2.17 & 208 \\
\hline July $13 \ldots . .$. & S. K. Clapp........ & 105 & 254 & 2.51 & 246 \\
\hline A ugust 22. & M. S. Brennan............... & 104 & 173 & 1.87 & 122 \\
\hline October 4 . & $\ldots$. do $\ldots . . . \ldots$. & 105 & 182 & 1. 92 & 133 \\
\hline December 7 & ... do...... & 113 & 516 & 5.00 & 451 \\
\hline $\begin{array}{r}1906 . \\
\text { March } 9\end{array}$ & $\mathrm{~F}$ & & & & \\
\hline $\begin{array}{l}\text { Maren } 9 . \\
\text { April 4.. }\end{array}$ & E. Ho Kriegsm & $\begin{array}{l}104 \\
138\end{array}$ & 745 & $\begin{array}{l}2.60 \\
6.42\end{array}$ & $\begin{array}{r}306 \\
1,870\end{array}$ \\
\hline April 5.. & ....do........ & 120 & 609 & 5. 60 & 1,610 \\
\hline May $11 .$. & .. do. & 65 & 56 & 1.40 & 58 \\
\hline May $11 .$. & . .do.. & 85 & 117 & 1. 40 & 55 \\
\hline June 29 . & ...do. & 46 & 22 & 1.07 & 31 \\
\hline
\end{tabular}


Daily gage height, in feet, of St. Marys River at Fort Wayne, Ind., for 1906.

\begin{tabular}{|c|c|c|c|c|c|c|c|}
\hline Day. & Jan. & Feb. & Mar. & Apr. & May. & June. & July. \\
\hline 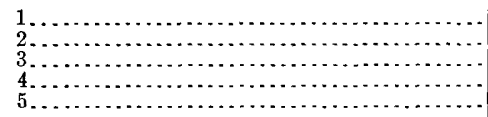 & $\begin{array}{l}3.25 \\
3.50 \\
3.85 \\
4.10 \\
4.35\end{array}$ & $\begin{array}{l}2.38 \\
2.53 \\
2.15 \\
2.05 \\
1.95\end{array}$ & $\begin{array}{l}\text { 2. } 20 \\
2.25 \\
2.68 \\
2.67 \\
2.60\end{array}$ & $\begin{array}{r}11.25 \\
9.95 \\
8.12 \\
6.42 \\
5.40\end{array}$ & $\begin{array}{l}\text { 1. } 54 \\
\text { 1. } 50 \\
\text { 1. } 48 \\
\text { 1. } 45 \\
\text { 1. } 43\end{array}$ & $\begin{array}{l}1.26 \\
1.28 \\
1.29 \\
1.30 \\
1.40\end{array}$ & $\begin{array}{l}\text { 1. } 02 \\
1.02 \\
1.02 \\
1.20 \\
1.35\end{array}$ \\
\hline $\begin{array}{r}6 \\
7 \\
8 \\
8\end{array}$ & $\begin{array}{l}4.05 \\
3.85 \\
3.40 \\
3.05 \\
3.00\end{array}$ & $\begin{array}{l}1.94 \\
1.93 \\
1.90 \\
1.87 \\
1.85\end{array}$ & $\begin{array}{l}2.57 \\
2.51 \\
2.45 \\
\text { 2. } 55 \\
\text { 2. } 53\end{array}$ & $\begin{array}{l}508 \\
\text { 4. } 45 \\
\text { 4. } 49 \\
\text { 7. } 98 \\
6.05\end{array}$ & $\begin{array}{l}\text { 1. } 40 \\
\text { 1. } 37 \\
\text { 1. } 35 \\
\text { 1. } 33 \\
\text { 1. } 32\end{array}$ & $\begin{array}{l}1.45 \\
1.50 \\
1.80 \\
1.89 \\
1.90\end{array}$ & $\begin{array}{l}\text { 1. } 49 \\
\text { 1. } 60 \\
\text { 1. } 63 \\
\text { 1. } 65 \\
1.72\end{array}$ \\
\hline $\begin{array}{l}11 \\
12 \\
13 \\
14 \\
15\end{array}$ & $\begin{array}{r}2.95 \\
2.80 \\
2.79 \\
\cdots \\
\cdots\end{array}$ & $\begin{array}{l}1.82 \\
\text { 1. } 80 \\
\text { 1. } 74 \\
\text { 1. } 70 \\
1.68\end{array}$ & $\begin{array}{l}2.51 \\
2.48 \\
2.45 \\
2.43 \\
2.35\end{array}$ & $\begin{array}{l}\text { 4. } 77 \\
\text { 3. } 96 \\
\text { 3. } 50 \\
\text { 6. } 38 \\
6.28\end{array}$ & $\begin{array}{l}\text { 1. } 32 \\
\text { 1. } 32 \\
\text { 1. } 29 \\
\text { 1. } 25 \\
\text { 1. } 22\end{array}$ & $\begin{array}{l}1.80 \\
1.72 \\
1.65 \\
\text { 1. } 56 \\
\text { 1. } 40\end{array}$ & $\begin{array}{l}1.95 \\
2.90 \\
2.65 \\
2.39 \\
1.90\end{array}$ \\
\hline 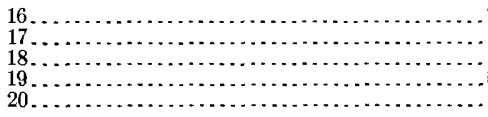 & $\begin{array}{r}2.85 \\
\ldots \ldots \\
\ldots \ldots \\
\ldots \ldots\end{array}$ & $\begin{array}{l}1.65 \\
1.63 \\
1.60 \\
1.57 \\
1.68\end{array}$ & $\begin{array}{l}\text { 2. } 15 \\
\text { 2. } 15 \\
\text { 2. } 45 \\
\text { 2. } 30 \\
\text { 2. } 20\end{array}$ & $\begin{array}{l}\text { 4. } 95 \\
\text { 4. } 06 \\
\text { 3. } 55 \\
\text { 3. } 11 \\
2.80\end{array}$ & $\begin{array}{l}\text { 1. } 20 \\
\text { 1. } 18 \\
\text { 1. } 17 \\
\text { 1. } 16 \\
\text { 1. } 15\end{array}$ & $\begin{array}{l}\text { 1. } 35 \\
\text { 1. } 40 \\
\text { 1. } 45 \\
\text { 1. } 45 \\
\text { 1. } 40\end{array}$ & $\begin{array}{l}\text { 1. } 50 \\
1.35 \\
1.32 \\
\text { 1. } 29 \\
1.26\end{array}$ \\
\hline $\begin{array}{l}21 \\
22 \\
23 \\
24 \\
25\end{array}$ & $\begin{array}{l}\text { 5. } 37 \\
7.00 \\
6.15 \\
\text { 5. } 40 \\
\text { 4. } 33\end{array}$ & $\begin{array}{l}1.75 \\
1.80 \\
1.89 \\
2.02 \\
2.86\end{array}$ & $\begin{array}{l}2.10 \\
2.05 \\
2.00 \\
1.82 \\
1.85\end{array}$ & $\begin{array}{l}\text { 2. } 52 \\
2.27 \\
2.14 \\
2.01 \\
1.90\end{array}$ & $\begin{array}{l}1.15 \\
1.14 \\
1.13 \\
1.12 \\
1.12\end{array}$ & $\begin{array}{l}1.35 \\
\text { 1. } 33 \\
\text { 1. } 30 \\
1.24 \\
1.18\end{array}$ & 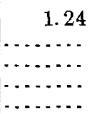 \\
\hline $\begin{array}{l}26 \\
27 \\
28 \\
28 \\
29 \\
30 \\
31\end{array}$ & $\begin{array}{l}3.51 \\
3.10 \\
2.70 \\
2.51 \\
2.42 \\
2.33\end{array}$ & $\begin{array}{r}2.83 \\
2.90 \\
3.22 \\
\ldots . . . \\
\ldots . . . \\
\end{array}$ & $\begin{array}{r}2.05 \\
10.42 \\
10.92 \\
10.20 \\
10.20 \\
11.60\end{array}$ & $\begin{array}{r}1.85 \\
1.83 \\
1.80 \\
1.72 \\
1.57 \\
\text {..... }\end{array}$ & $\begin{array}{l}1.11 \\
1.10 \\
1.10 \\
1.09 \\
1.09 \\
1.22\end{array}$ & $\begin{array}{l}1.15 \\
1.12 \\
1.10 \\
1.06 \\
1.02\end{array}$ & $\begin{array}{c}\cdots \\
\cdots \\
\cdots \\
\cdots \\
\cdots \\
\cdots \\
\cdots \\
\cdots\end{array}$ \\
\hline
\end{tabular}

NoTE.-The river was frozen January 14 to 20 , the ice reaching a thickness of 4 inches. The river was clear of ice on January 21 , and was probably not obstructed after that date, except on February 28 and March 18 to 20, on which dates there was backwater caused by an ice gorge below.

Rating table for St. Marys Rvver at Fort Wayne, Ind., for 1905-6.

\begin{tabular}{|c|r|r|r|r|r|r|r|}
\hline $\begin{array}{c}\text { Gage } \\
\text { height. }\end{array}$ & $\begin{array}{c}\text { Dis- } \\
\text { charge. }\end{array}$ & $\begin{array}{c}\text { Gage } \\
\text { height. }\end{array}$ & $\begin{array}{c}\text { Dis- } \\
\text { charge. }\end{array}$ & $\begin{array}{c}\text { Gage } \\
\text { height. }\end{array}$ & $\begin{array}{c}\text { Dis- } \\
\text { charge. }\end{array}$ & $\begin{array}{c}\text { Gage } \\
\text { height. }\end{array}$ & $\begin{array}{c}\text { Dis- } \\
\text { charge. }\end{array}$ \\
\cline { 1 - 5 } Feet. & Sec.-ft. & Feet. & Sec.-ft. & Feet. & Sec.ft. & Feet. & Sec. ft. \\
1.00 & 23 & 2.30 & 210 & 3.60 & 586 & 5.80 & 1,530 \\
1.10 & 30 & 2.40 & 234 & 3.70 & 620 & 6.00 & 1,630 \\
1.20 & 38 & 2.50 & 260 & 3.80 & 655 & 6.20 & 1,730 \\
1.30 & 47 & 2.60 & 286 & 3.90 & 690 & 6.40 & 1,850 \\
1.40 & 57 & 2.70 & 314 & 4.00 & 725 & 6.60 & 1,970 \\
1.50 & 69 & 2.80 & 342 & 4.20 & 800 & 6.80 & 2,090 \\
1.60 & 82 & 2.90 & 370 & 4.40 & 880 & 7.00 & 2,210 \\
1.70 & 96 & 3.00 & 400 & 4.60 & 960 & 8.00 & 2,810 \\
1.80 & 111 & 3.10 & 430 & 4.80 & 1,040 & 9.00 & 3,510 \\
1.90 & 127 & 3.20 & 460 & 5.00 & 1,130 & 10.00 & 4,210 \\
2.00 & 145 & 3.30 & 490 & 5.20 & 1,230 & 11.00 & 5,010 \\
2.10 & 165 & 3.40 & 522 & 5.40 & 1,330 & 12.00 & 5,810 \\
2.20 & 187 & 3.50 & 554 & 5.60 & 1,430 & & \\
\hline
\end{tabular}

Note.-The above table is applicable only for open-channel conditions. It is based on twelve discharge measurements made during 1905-6. It is well defined between gage heights 1.0 foot and 2.7 feet, and is fairly well defined above 2.7 feet. 
Monthly discharge of St. Marys River at Fort Wayne, Ind., for 1905-6.

[Drainage area, 740 square miles.]

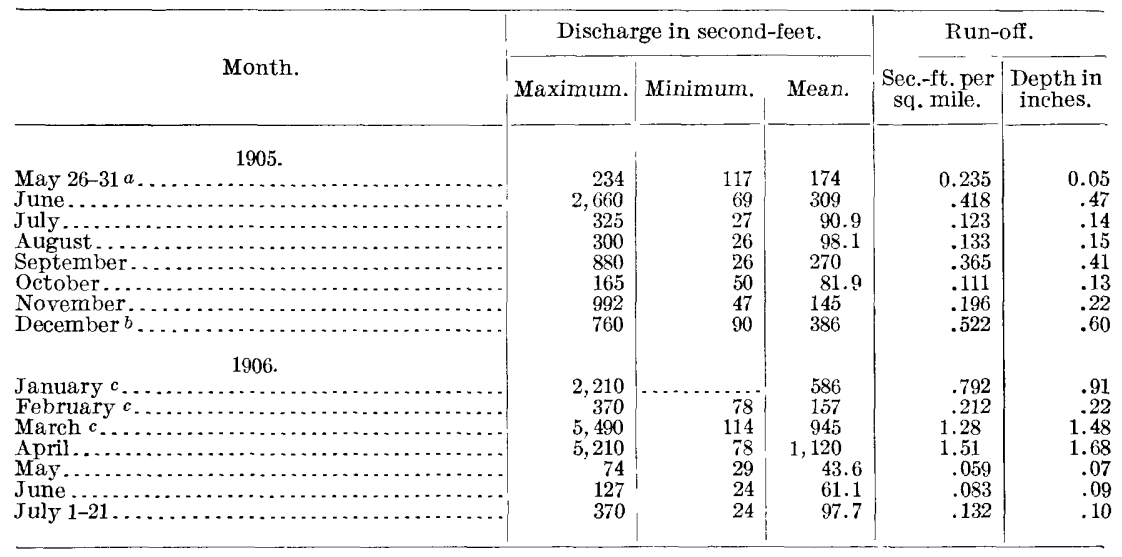

$a$ Owing to errors in chain length, no reliable estimates of discharge can be made prior to May 26 , 1905.

$b$ Backwater caused by ice gorge below gage December 4 to 8 and 13 to 16,1905 ; discharge estimated. c During ice periods discharge estimated.

NoTE.-Values for 1905 and 1906 are good.

\section{TIFFIN RIVER NEAR DEFIANCE, OHIO.}

This station was established May 19, 1903, and was discontinued March 31, 1906. It was located at the highway bridge on the new road to Evansport, one-half mile above the settlement of Brunnesburg and 3 miles by river above the center of the city of Defiance. The conditions at this station and the bench marks are described in WaterSupply Paper No. 170 , page 56 , where are given also references to publications that contain data for previous years.

A measurement was made March 8, 1906, by E. F. Kriegsman, with the following results:

Width, 107 feet; area, 434 square feet; gage height, 4.69 feet; discharge, 507 secondfeet.

Daily gage height, in feet, of Tiffn River near Defiance, Ohio, for 1906.

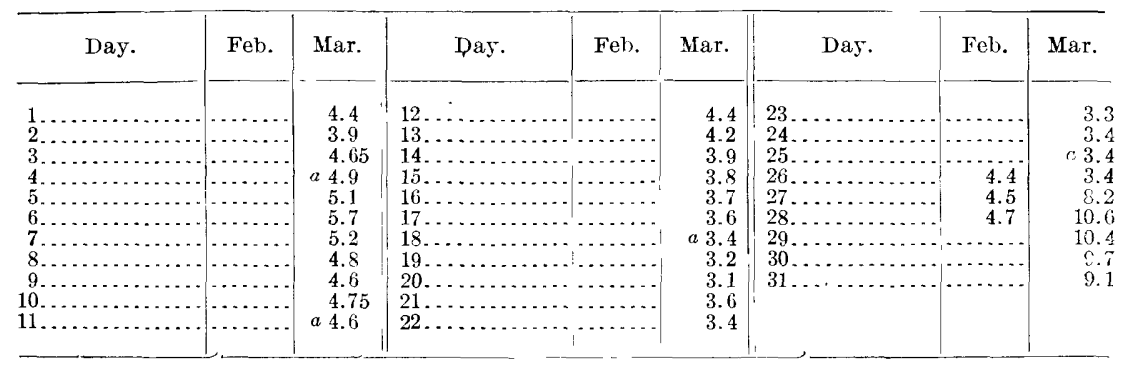

a Gage heights interpolated. 
Rating table for Tiffin River near Defiance, Ohio, for 1906.

\begin{tabular}{|c|c|c|c|c|c|c|c|}
\hline $\begin{array}{c}\text { Gage } \\
\text { height. }\end{array}$ & $\begin{array}{c}\text { Dis- } \\
\text { charge. }\end{array}$ & $\begin{array}{c}\text { Gage } \\
\text { height. }\end{array}$ & $\begin{array}{c}\text { Dis- } \\
\text { charge. }\end{array}$ & $\begin{array}{c}\text { Gage } \\
\text { height. }\end{array}$ & $\begin{array}{c}\text { Dis- } \\
\text { charge. }\end{array}$ & $\begin{array}{c}\text { Gage } \\
\text { height. }\end{array}$ & $\begin{array}{c}\text { Dis- } \\
\text { charge. }\end{array}$ \\
\hline $\begin{array}{r}\text { Feet. } \\
3.10 \\
3.20 \\
3.30 \\
3.40 \\
3.50 \\
3.60 \\
3.70\end{array}$ & $\begin{array}{r}\text { Sec. } f t \\
159 \\
178 \\
198 \\
219 \\
240 \\
262 \\
285\end{array}$ & $\begin{array}{r}\text { feet. } \\
3.80 \\
3.90 \\
4.00 \\
4.10 \\
4.20 \\
4.30 \\
4.40\end{array}$ & $\begin{array}{r}\text { Sec. } f t . \\
309 \\
334 \\
360 \\
387 \\
414 \\
442 \\
470\end{array}$ & $\begin{array}{r}\text { Feet. } \\
4.50 \\
4.60 \\
4.70 \\
4.80 \\
4.90 \\
5.00 \\
6.00\end{array}$ & $\begin{array}{r}\text { Sec. } f t \\
499 \\
528 \\
558 \\
588 \\
619 \\
650 \\
970\end{array}$ & $\begin{array}{r}\text { Feet. } \\
7.00 \\
8.00 \\
9.00 \\
10.00 \\
11.00\end{array}$ & $\begin{array}{r}\text { Sec.-ft. } \\
1,320 \\
1,690 \\
2,090 \\
2,500 \\
2,930\end{array}$ \\
\hline
\end{tabular}

NotE.-The above table is applicable only for open-channel conditions. It is based on discharge measurements made during 1903-1906, and is well defined below gage height 5.7 feet.

Monthly discharge of Tiffin River near Defiance, Ohio, for 1906.

[Drainage area, 748 square riles.]

\begin{tabular}{|c|c|c|c|c|c|}
\hline \multirow{2}{*}{ Month. } & \multicolumn{3}{|c|}{ Discharge in second-feet. } & \multicolumn{2}{|c|}{ Run-off. } \\
\hline & Maximum. & Minìmum. & Mean. & $\begin{array}{l}\text { Sec-ft.per } \\
\text { so. mile. }\end{array}$ & $\begin{array}{l}\text { Depth in } \\
\text { inches. }\end{array}$ \\
\hline $\begin{array}{l}\text { February }(26-28) \\
\text { March............ }\end{array}$ & $\begin{array}{r}5558 \\
2,760\end{array}$ & $\begin{array}{l}470 \\
159\end{array}$ & $\begin{array}{l}509 \\
714\end{array}$ & $\begin{array}{r}0.680 \\
.955\end{array}$ & $\begin{array}{l}0.08 \\
1.10\end{array}$ \\
\hline
\end{tabular}

NoTE.-Values for 1906 are excellent.

\section{BLACK RIVER BASIN.}

\section{BLACK RIVER NEAR ELYRIA, OHIO.}

This station was established May 23, 1903, the object being to furnish data for the water supply of nearby towns, and was discontinued July 21, 1906. It was located at the North Ridge Road Bridge, about 5 miles from the center of the city of Elyria. The conditions at this station and the bench marks are described in Water-Supply Paper No. 170, page 59, where are given also references to publications that contain data for previous years.

Discharge measurements of Black River near Elyra, Ohio, in 1904-1906.

\begin{tabular}{|c|c|c|c|c|c|}
\hline Date. & Hydrographer. & Width. & $\begin{array}{l}\text { A rea of } \\
\text { section. }\end{array}$ & $\begin{array}{c}\text { Gage } \\
\text { height. }\end{array}$ & Discharge. \\
\hline $\begin{array}{r}1904 . \\
\text { March } 9 \ldots . .\end{array}$ & R. W. Pratt. & $\begin{array}{l}\text { Feet. } \\
79\end{array}$ & $S q . f t$. & $\begin{array}{l}\text { Feet. } \\
3.55\end{array}$ & $\begin{array}{l}\text { Sec.-ftt. } \\
691\end{array}$ \\
\hline May $17 . . .$. & $\begin{array}{l}\text { R. W. Pratt. } \\
\text {....do....... }\end{array}$ & 63 & $\begin{array}{r}18 \times \\
66\end{array}$ & $\begin{array}{l}3.30 \\
1.70\end{array}$ & $\begin{array}{r}691 \\
68\end{array}$ \\
\hline June 22 & a & 3 & 20 & 1.15 & 12 \\
\hline Do. & … & 35 & 19 & 1.15 & 11.4 \\
\hline July 6 . & (n.......... & 80 & 246 & 4.11 & 894 \\
\hline July & ......... & 41 & 24 & 1.28 & 25 \\
\hline Angust & 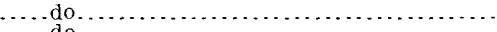 & 34 & 14 & 1.05 & 8.2 \\
\hline $\begin{array}{l}\text { October } \\
\text { Novemb }\end{array}$ & $\cdots$ do $\ldots . . . \cdots \cdots$ & 35 & 17 & 1.14 & 10.5 \\
\hline November $4 \ldots$. & & 33 & 13 & 0.96 & 2.8 \\
\hline & & & & & \\
\hline Januar & R. W. Pratt.. & 75 & 119 & 2.80 & 114 \\
\hline $\begin{array}{l}\text { Fehruary } \\
\text { May } 24 . .\end{array}$ & Mdo .......... & & 41 & 1.75 & 24 \\
\hline $\begin{array}{l}\text { May } 24 . . \\
\text { October }\end{array}$ & M. S. Brennan. & 69 & 52 & 1.44 & 56 \\
\hline November $4 \ldots$ & K... Wo....... & 55 & 30 & 1.15 & $\begin{array}{l}10.3 \\
12\end{array}$ \\
\hline 190 & & & & & \\
\hline March 7 & E. F, Kriegsman & 68 & 66 & 1.52 & 103 \\
\hline May 14. & & 66 & 42 & 1.33 & 48 \\
\hline
\end{tabular}

a River frozen over; measurements indicate that flow is about 25 per cent of the open-channel discharge for the same gige heights. 
Daily gage height, in feet, of Black River near Elyria, Ohio, for 1905-6.

1905.

\begin{tabular}{|c|c|c|c|c|c|c|c|c|c|c|c|c|}
\hline Day. & Jan. & Feb. & Mar. & Apr. & May. & June. & July. & Aug. & Sent. & Oct. & Nov. & Dec. \\
\hline $\begin{array}{l}1 \ldots \\
2 \ldots \\
3 \ldots \\
4 \ldots \\
5 \ldots\end{array}$ & $\begin{array}{l}2.4 \\
2.35 \\
2.3 \\
2.15 \\
2.1\end{array}$ & $\begin{array}{l}1.1 \\
1.1 \\
1.2 \\
1.2 \\
1.1\end{array}$ & $\begin{array}{l}6.0 \\
4.0 \\
4.0 \\
4.0 \\
4.0\end{array}$ & $\begin{array}{l}1.7 \\
1.5 \\
1.4 \\
1.4 \\
1.3\end{array}$ & $\begin{array}{l}1.8 \\
1.8 \\
1.6 \\
1.5 \\
1.5\end{array}$ & $\begin{array}{l}1.45 \\
1.4 \\
1.4 \\
1.35 \\
1.2\end{array}$ & $\begin{array}{l}1.1 \\
1.0 \\
1.0 \\
1.1 \\
1.4\end{array}$ & $\begin{array}{r}0.9 \\
.9 \\
.9 \\
1.0 \\
1.4\end{array}$ & $\begin{array}{l}1.1 \\
1.1 \\
1.0 \\
1.0 \\
1.0\end{array}$ & $\begin{array}{l}1.0 \\
1.1 \\
1.1 \\
1.0 \\
1.0\end{array}$ & $\begin{array}{l}1.2 \\
1.2 \\
1.1 \\
1.1 \\
1.1\end{array}$ & $\begin{array}{l}4.3 \\
4.0 \\
3.7 \\
3.4 \\
3.1\end{array}$ \\
\hline $\begin{array}{r}6 \ldots \ldots \\
7 \ldots \ldots \\
8 \ldots \ldots \ldots \\
9 \ldots \ldots \ldots \\
10 \ldots \ldots\end{array}$ & $\begin{array}{l}2.4 \\
2.4 \\
2.2 \\
2.1 \\
1.7\end{array}$ & $\begin{array}{l}1.1 \\
1.0 \\
1.0 \\
1.1 \\
1.1\end{array}$ & $\begin{array}{l}4.0 \\
4.1 \\
5.0 \\
6.0 \\
5.0\end{array}$ & $\begin{array}{l}1.3 \\
1.2 \\
1.2 \\
1.2 \\
1.4\end{array}$ & $\begin{array}{l}1.4 \\
1.5 \\
1.4 \\
1.3 \\
1.4\end{array}$ & $\begin{array}{l}2.5 \\
2.5 \\
3.5 \\
3.5 \\
3.0\end{array}$ & $\begin{array}{l}1.4 \\
1.3 \\
1.35 \\
1.3 \\
1.4\end{array}$ & $\begin{array}{r}1.5 \\
1.4 \\
.9 \\
.9 \\
1.1\end{array}$ & $\begin{array}{l}1.05 \\
1.05 \\
1.0 \\
1.0 \\
1.05\end{array}$ & $\begin{array}{l}1.1 \\
1.1 \\
1.1 \\
\mathbf{1 . 0 5} \\
.9\end{array}$ & $\begin{array}{l}1.1 \\
1.9 \\
2.2 \\
2.1 \\
2.0\end{array}$ & $\begin{array}{l}2.8 \\
2.4 \\
2.4 \\
2.3 \\
2.2\end{array}$ \\
\hline $\begin{array}{l}11 \ldots \ldots \\
12 \ldots \ldots \\
13 \ldots \ldots \\
14 \ldots \\
15 \ldots\end{array}$ & $\begin{array}{l}2.1 \\
2.2 \\
2.0 \\
1.9 \\
1.7\end{array}$ & $\begin{array}{l}1.05 \\
1.05 \\
.9 \\
.9 \\
.9\end{array}$ & $\begin{array}{l}5.1 \\
5.0 \\
5.0 \\
4.1 \\
4.0\end{array}$ & $\begin{array}{l}1.5 \\
5.0 \\
4.0 \\
3.5 \\
2.2\end{array}$ & $\begin{array}{r}1.9 \\
11.1 \\
8.0 \\
4.1 \\
3.0\end{array}$ & $\begin{array}{l}2.0 \\
3.0 \\
2.1 \\
2.05 \\
1.1\end{array}$ & $\begin{array}{l}1.35 \\
1.3 \\
1.2 \\
1.2 \\
1.1\end{array}$ & $\begin{array}{l}1.1 \\
1.1 \\
1.0 \\
1.5 \\
2.5\end{array}$ & $\begin{array}{l}1.1 \\
1.2 \\
1.4 \\
1.4 \\
1.3\end{array}$ & $\begin{array}{l}\mathbf{1 . 1} \\
\mathbf{1 . 1} \\
\mathbf{1 . 2} \\
\mathbf{1 . 2} \\
\mathbf{1 . 1}\end{array}$ & $\begin{array}{l}1.8 \\
1.6 \\
1.5 \\
1.5 \\
1.4\end{array}$ & $\begin{array}{l}2.2 \\
2.1 \\
2.1 \\
2.1 \\
2.0\end{array}$ \\
\hline $\begin{array}{l}16 \ldots \\
17 \ldots \\
18 \ldots \\
19 \ldots \\
20 \ldots\end{array}$ & $\begin{array}{l}2.1 \\
2.8 \\
3.3 \\
2.1 \\
2.0\end{array}$ & $\begin{array}{l}.9 \\
.9 \\
1.0 \\
1.0 \\
1.05\end{array}$ & $\begin{array}{l}2.1 \\
2.1 \\
3.0 \\
5.1 \\
6.0\end{array}$ & $\begin{array}{l}2.5 \\
2.5 \\
3.0 \\
2.1 \\
2.1\end{array}$ & $\begin{array}{l}3.5 \\
3.5 \\
3.5 \\
3.0 \\
2.1\end{array}$ & $\begin{array}{l}2.0 \\
3.5 \\
3.0 \\
2.5 \\
2.0\end{array}$ & $\begin{array}{l}1.1 \\
1.1 \\
1.0 \\
1.0 \\
1.05\end{array}$ & $\begin{array}{l}2.5 \\
2.5 \\
2.0 \\
2.0 \\
2.0\end{array}$ & $\begin{array}{l}1.2 \\
1.1 \\
2.5 \\
2.0 \\
1.8\end{array}$ & $\begin{array}{l}1.1 \\
1.2 \\
1.2 \\
1.3 \\
1.2\end{array}$ & $\begin{array}{l}1.4 \\
1.3 \\
1.3 \\
1.2 \\
1.2\end{array}$ & $\begin{array}{l}1.9 \\
1.7 \\
1.6 \\
1.5 \\
1.3\end{array}$ \\
\hline $\begin{array}{l}21 \ldots \\
22 \ldots \\
23 \ldots \\
24 \ldots \\
25 \ldots\end{array}$ & $\begin{array}{l}1.7 \\
1.6 \\
1.5 \\
1.5 \\
1.6\end{array}$ & $\begin{array}{l}1.3 \\
1.35 \\
3.0 \\
3.0 \\
4.0\end{array}$ & $\begin{array}{l}5.0 \\
4.1 \\
3.0 \\
3.0 \\
2.5\end{array}$ & $\begin{array}{l}6.1 \\
6.0 \\
4.1 \\
3.0 \\
2.1\end{array}$ & $\begin{array}{l}2.0 \\
2.0 \\
1.9 \\
1.5 \\
1.4\end{array}$ & $\begin{array}{l}2.0 \\
1.7 \\
1.5 \\
1.4 \\
1.3\end{array}$ & $\begin{array}{l}1.0 \\
1.15 \\
1.1 \\
1.1 \\
1.05\end{array}$ & $\begin{array}{l}2.0 \\
1.8 \\
2.5 \\
2.0 \\
2.0\end{array}$ & $\begin{array}{l}2.0 \\
1.8 \\
1.7 \\
1.5 \\
1.5\end{array}$ & $\begin{array}{l}1.5 \\
1.9 \\
1.8 \\
1.7 \\
1.5\end{array}$ & $\begin{array}{l}1,2 \\
1.1 \\
1.1 \\
1.0 \\
1.0\end{array}$ & $\begin{array}{l}1.3 \\
3.3 \\
3.0 \\
2.6 \\
2.4\end{array}$ \\
\hline $\begin{array}{l}26 \ldots \\
27 \ldots \\
28 \ldots \\
29 \ldots \\
30 \ldots \\
31 \ldots\end{array}$ & $\begin{array}{l}1.55 \\
1.5 \\
1.4 \\
1.2 \\
1.2 \\
1.1\end{array}$ & $\begin{array}{r}4.0 \\
6.0 \\
7.0 \\
\ldots \ldots . \\
\ldots \ldots . . \\
\ldots . .\end{array}$ & $\begin{array}{l}2.5 \\
2.5 \\
2.5 \\
2.0 \\
1.8 \\
1.7\end{array}$ & $\begin{array}{l}2.0 \\
3.1 \\
2.1 \\
2.0 \\
1.8\end{array}$ & $\begin{array}{l}1.6 \\
3.0 \\
2.8 \\
2.7 \\
2.6 \\
2.5\end{array}$ & $\begin{array}{l}1.2 \\
1.1 \\
1.1 \\
1.05 \\
1.0\end{array}$ & $\begin{array}{l}1.0 \\
1.0 \\
1.1 \\
1.1 \\
1.0 \\
1.0\end{array}$ & $\begin{array}{l}1.8 \\
1.5 \\
1.4 \\
1.4 \\
1.3 \\
1.2\end{array}$ & $\begin{array}{l}1.4 \\
1.3 \\
1.2 \\
1.1 \\
1.0\end{array}$ & $\begin{array}{l}\mathbf{1 . 5} \\
1.4 \\
1.2 \\
\mathbf{1 . 1} \\
1.1 \\
1.2\end{array}$ & $\begin{array}{l}1.0 \\
1.1 \\
1.4 \\
1.9 \\
4.5\end{array}$ & $\begin{array}{l}2.0 \\
1.6 \\
1.5 \\
1.8 \\
2.1 \\
2.0\end{array}$ \\
\hline
\end{tabular}

1906.

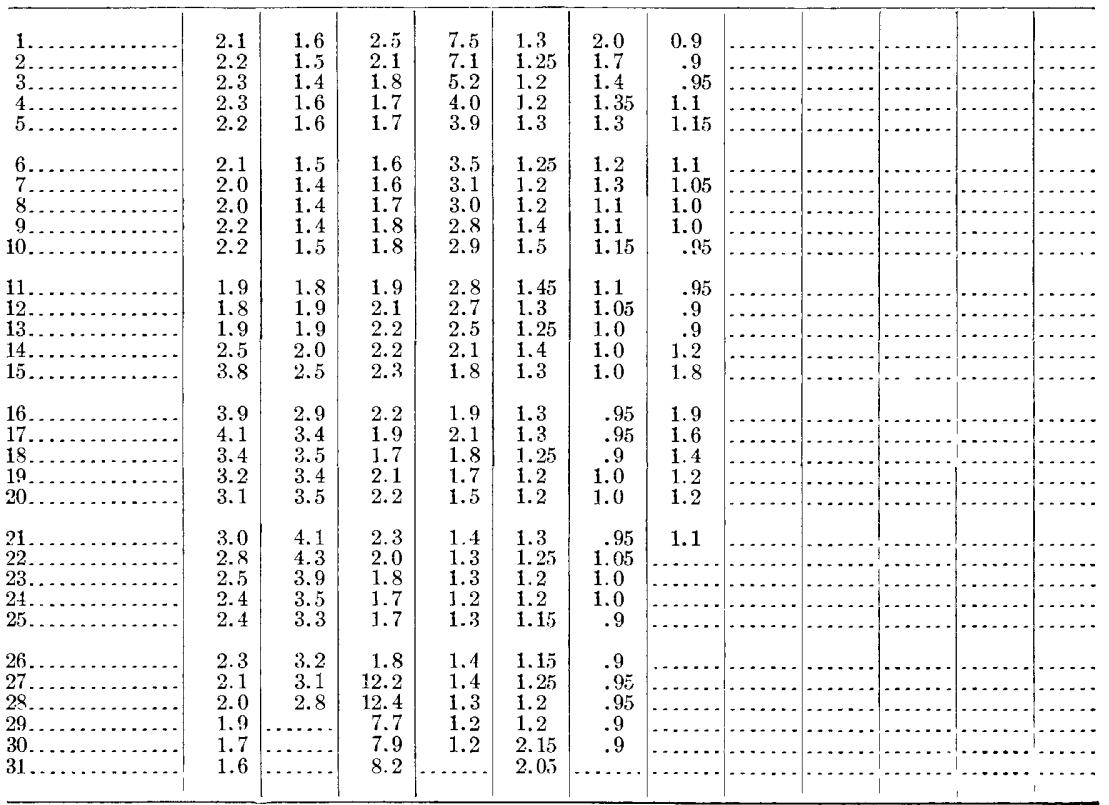

Note. - The above gage heights for 190:5-6 were recorded erroneously in some cases, but have been corrected as far as possible. They are still liable to some error. Ice conditions January 1 to February 281905 . River frozen February 1 to 18,1906 ; thickness of ice, 0.2 to 0.8 foot. 
Rating table for Black River near Elyra, Ohio, for 1904-1906.

\begin{tabular}{|c|c|c|c|c|c|c|c|}
\hline $\begin{array}{c}\text { Gage } \\
\text { height. }\end{array}$ & $\begin{array}{l}\text { Dis- } \\
\text { charge. }\end{array}$ & $\begin{array}{c}\text { Gage } \\
\text { height. }\end{array}$ & $\begin{array}{c}\text { Dis- } \\
\text { charge. }\end{array}$ & $\begin{array}{c}\text { Gage } \\
\text { height. }\end{array}$ & $\begin{array}{c}\text { Dis- } \\
\text { charge. }\end{array}$ & $\begin{array}{c}\text { Gage } \\
\text { height. }\end{array}$ & $\begin{array}{c}\text { Dis- } \\
\text { charge. }\end{array}$ \\
\hline $\begin{array}{r}\text { Feet. } \\
0.90 \\
1.00 \\
1.10 \\
1.20 \\
1.30 \\
1.40 \\
1.50 \\
1.60 \\
1.70 \\
1.80 \\
1.90 \\
2.00 \\
2.10 \\
2.20\end{array}$ & $\begin{array}{r}\text { Sec. ft. } \\
2 \\
5 \\
10 \\
18 \\
31 \\
48 \\
70 \\
94 \\
120 \\
148 \\
177 \\
206 \\
235 \\
264\end{array}$ & $\begin{array}{r}\text { Feet. } \\
2.30 \\
2.40 \\
2.50 \\
2.60 \\
2.70 \\
2.80 \\
2.90 \\
3.00 \\
3.10 \\
3.20 \\
3.30 \\
3.40 \\
3.50 \\
3.60\end{array}$ & $\begin{array}{r}\text { Sec.ft. } \\
294 \\
324 \\
355 \\
386 \\
417 \\
448 \\
479 \\
510 \\
544 \\
578 \\
612 \\
646 \\
680 \\
714\end{array}$ & $\begin{array}{r}\text { Feet. } \\
3.70 \\
3.80 \\
3.90 \\
4.00 \\
4.20 \\
4.40 \\
4.60 \\
4.80 \\
5.00 \\
5.20 \\
5.40 \\
5.60 \\
5.80\end{array}$ & $\begin{array}{r}\text { Sec. } f t . \\
748 \\
782 \\
816 \\
850 \\
920 \\
990 \\
1,060 \\
1,130 \\
1,200 \\
1,270 \\
1,340 \\
1,410 \\
1,480\end{array}$ & $\begin{array}{r}\text { Feet. } \\
6.00 \\
7.00 \\
8.00 \\
9.00 \\
10.00 \\
11.00 \\
12.00 \\
13.00 \\
14.00 \\
15.00 \\
16.00 \\
17.00 \\
18.00\end{array}$ & $\begin{array}{r}\text { Sec.-ft. } \\
1,550 \\
1,900 \\
2,250 \\
2,600 \\
2,950 \\
3,300 \\
3,650 \\
4,000 \\
4,350 \\
4,700 \\
5,050 \\
5,400 \\
5,750\end{array}$ \\
\hline
\end{tabular}

Note.-The above table is applicable only for open-channel conditions. It is based on discharge measurements made during 1904-1906, and is not well defined.

Monthly discharge of Black River near Elyria, Ohio, for 1904-1906.

[Drainage area, 417 square miles.]

\begin{tabular}{|c|c|c|c|c|c|}
\hline \multirow[b]{2}{*}{ Month. } & \multicolumn{3}{|c|}{ Discharge in second-feet. } & \multicolumn{2}{|c|}{ Run-off. } \\
\hline & Maximum. & Minimum. & Mean. & $\begin{array}{l}\text { Sec.-ft. per } \\
\text { sq. mile. }\end{array}$ & $\begin{array}{l}\text { Depth in } \\
\text { inches. }\end{array}$ \\
\hline 1904. & & & & & \\
\hline January ................. & 5,920 & 31 & 808 & 1.94 & 2. 24 \\
\hline February . . & 3,720 & 235 & 869 & 2.09 & 2.25 \\
\hline 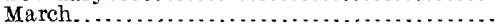 & 4,210 & 70 & 1,210 & 2.90 & 3.34 \\
\hline April $\ldots . .6 \ldots$ & 4,140 & 18 & 676 & 1. 62 & 1.81 \\
\hline May ............... & 1,480 & 5 & 227 & .544 & .63 \\
\hline June. & 2,500 & 5 & 300 & .719 & .80 \\
\hline . & 2,500 & 5 & 255 & .612 & .71 \\
\hline$\ldots \ldots \ldots \ldots \ldots \ldots$ & 177 & 2 & 68.8 & .165 & .19 \\
\hline$\ldots \ldots \ldots \ldots \ldots \ldots \ldots \ldots$ & 31 & 2 & 11.0 & .026 & .03 \\
\hline$\ldots \ldots \ldots \ldots \ldots \ldots \ldots \ldots$ & 31 & 2 & a 12.1 & .029 & .03 \\
\hline 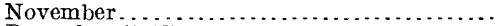 & 177 & $\overline{2}$ & 75.1 & .180 & .20 \\
\hline December $(1-18) \ldots$ & 94 & $\overline{5}$ & 48.0 & .115 & .08 \\
\hline 1905. & & & & & \\
\hline March............. & 1,550 & 120 & 799 & 1.92 & 2.21 \\
\hline April ........... & 1,580 & 18 & 371 & .890 & .99 \\
\hline 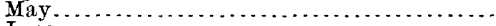 & 3,340 & 31 & 440 & 1.06 & 1. 22 \\
\hline 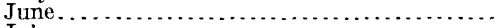 & 680 & 5 & 215 & .516 & .58 \\
\hline July ......... & 48 & 5 & 16.5 & .040 & .05 \\
\hline August..... & 355 & 2 & 112 & .269 & .31 \\
\hline September..... & 355 & 5 & 56.2 & .135 & .15 \\
\hline October........ & 177 & 2 & 32.1 & .077 & .09 \\
\hline$\ldots \ldots \ldots \ldots \ldots \ldots \ldots$ & 1,020 & 5 & 94.7 & .227 & .25 \\
\hline December........... & 955 & 31 & 319 & .765 & .88 \\
\hline 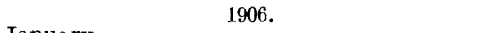 & & & & & \\
\hline 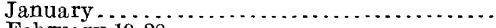 & 885 & 94 & 346 & .830 & .96 \\
\hline February $19-28 \ldots \ldots \ldots \ldots$ & 955 & 448 & 684 & 1.64 & .61 \\
\hline March....... & 3,790 & 94 & 616 & 1.48 & 1.71 \\
\hline April..... & 2,080 & 18 & 410 & .983 & 1. 10 \\
\hline May........ & 250 & 14 & 40.8 & .098 & .11 \\
\hline June $\ldots \ldots \ldots \ldots \ldots$ & 206 & 2 & 20.6 & .049 & .05 \\
\hline July $1-21 \ldots \ldots \ldots$ & 177 & 2 & 28.7 & .069 & .05 \\
\hline
\end{tabular}

$a$ Gage heights published as 1.01, 1.02, and 1.03 in Water-Supply Paper No. 129 should be 1.1, 1.2, and 1.3.

NotE.-The above values are rated as fair with the exception of January to March, 1904. No data concerning ice conditions during these months were available and hence the open-channel rating was applied for this period. The procedure may involve large errors. 


\section{CUYAHOGA RIVER BASIN.}

\section{DESCRIPTION OF BASIN.}

Cuyahoga River rises in eastern Geauga County, flows southsouthwestward to a point within about 2 miles of Akron, then turns sharply and flows northwestward to Lake Erie. Its course is extremely tortuous. In one place a straight line 5 miles long would connect two points 12 miles apart by the channel. The valley consists largely of a series of basins, the hills reaching 200 feet or more in height. Many lakes and swamps occur in the headwater region.

\section{CUYAHOGA RIVER AT INDEPENDENCE, OHIO.}

This station was established September 21, 1903, and was discontinued July 21, 1906. It was located at the highway bridge at the town of Independence, 10 miles south of Cleveland and 4 miles south of the gaging station formerly located on the highway bridge between Brooklyn and Newberg, Ohio. The conditions at this station and the bench marks are described in Water-Supply Paper No. 170, page 60 , where are given also references to publications that contain data for previous years.

Discharge measurements of Cuyahoga River at Independence, Ohio, in 1906.

\begin{tabular}{|c|c|c|c|c|c|}
\hline Date. & Hydrographer. & Width. & $\begin{array}{l}\text { Area of } \\
\text { section. }\end{array}$ & $\begin{array}{c}\text { Gage } \\
\text { height. }\end{array}$ & $\begin{array}{c}\text { Dis- } \\
\text { charge. }\end{array}$ \\
\hline $\begin{array}{l}\text { March } 7 \ldots . \\
\text { May } 14 \ldots . .\end{array}$ & 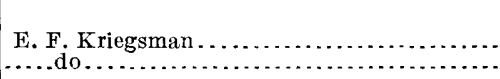 & $\begin{array}{r}\text { Feet. } \\
78 \\
62\end{array}$ & $\begin{array}{r}\text { Sq. ft. } \\
335 \\
264\end{array}$ & $\begin{array}{r}\text { Feet. } \\
6.26 \\
5.39\end{array}$ & $\begin{array}{r}\text { Sec.-ft. } \\
803 \\
419\end{array}$ \\
\hline
\end{tabular}

Daily gage height, in feet, of Cuyahoga River at Independence, Ohıo, for 1906.

\begin{tabular}{|c|c|c|c|c|c|c|c|}
\hline Day. & Jan. & Feb. $a$ & Mar. & Apr. & May. & June. & July. \\
\hline $\begin{array}{l}1 \ldots \\
2 \ldots \\
3 \ldots \\
4 \ldots \\
5 \ldots\end{array}$ & $\begin{array}{l}5.75 \\
5.4 \\
5.35 \\
7.2 \\
6.85\end{array}$ & $\begin{array}{l}5.25 \\
4.75 \\
4.9 \\
5.0 \\
5.25\end{array}$ & $\begin{array}{l}5.4 \\
5.25 \\
5.45 \\
5.9 \\
6.4\end{array}$ & $\begin{array}{l}9.1 \\
8.8 \\
7.75 \\
6.65 \\
6.4\end{array}$ & $\begin{array}{l}5.1 \\
5.05 \\
5.0 \\
5.05 \\
5.65\end{array}$ & $\begin{array}{l}4.8 \\
5.5 \\
5.0 \\
4.9 \\
4.8\end{array}$ & $\begin{array}{l}4.5 \\
4.5 \\
4.55 \\
5.0 \\
4.85\end{array}$ \\
\hline 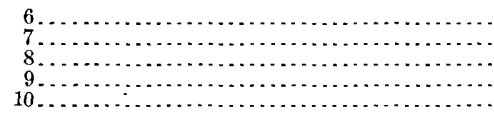 & $\begin{array}{l}6.55 \\
6.4 \\
6.25 \\
5.75 \\
5.45\end{array}$ & $\begin{array}{l}5.25 \\
5.5 \\
5.5 \\
5.5 \\
5.5\end{array}$ & $\begin{array}{l}6.2 \\
6.25 \\
6.2 \\
6.05 \\
6.3\end{array}$ & $\begin{array}{l}7.0 \\
6.7 \\
6.0 \\
6.35 \\
7.5\end{array}$ & $\begin{array}{l}5.9 \\
6.4 \\
6.05 \\
5.8 \\
6.0\end{array}$ & $\begin{array}{l}4.95 \\
5.05 \\
5.1 \\
5.0 \\
4.95\end{array}$ & $\begin{array}{l}5.0 \\
5.2 \\
5.1 \\
4.85 \\
5.0\end{array}$ \\
\hline $\begin{array}{l}11 \ldots \\
12 \ldots \\
13 \ldots \\
15 \ldots\end{array}$ & $\begin{array}{l}5.6 \\
5.4 \\
5.4 \\
5.35 \\
5.3\end{array}$ & $\begin{array}{l}5.48 \\
5.45 \\
5.45 \\
5.4 \\
5.4\end{array}$ & $\begin{array}{l}6.5 \\
6.4 \\
5.5 \\
5.4 \\
5.3\end{array}$ & $\begin{array}{l}7.1 \\
7.0 \\
7.0 \\
6.85 \\
6.6\end{array}$ & $\begin{array}{l}6.75 \\
5.6 \\
5.6 \\
5.55 \\
5.3\end{array}$ & $\begin{array}{l}4.65 \\
4.8 \\
4.65 \\
4.6 \\
4.7\end{array}$ & $\begin{array}{l}4.8 \\
4.7 \\
4.7 \\
4.5 \\
4.5\end{array}$ \\
\hline 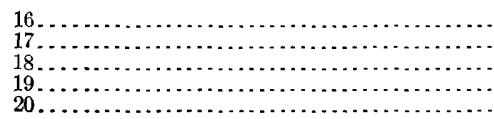 & $\begin{array}{l}6.25 \\
5.95 \\
6.0 \\
6.95 \\
6.7\end{array}$ & $\begin{array}{l}5.4 \\
5.4 \\
5.4 \\
5.4 \\
5.4\end{array}$ & $\begin{array}{l}5.25 \\
5.2 \\
5.2 \\
5.2 \\
5.2\end{array}$ & $\begin{array}{l}6.35 \\
6.15 \\
5.8 \\
5.65 \\
5.4\end{array}$ & $\begin{array}{l}5.2 \\
5.2 \\
5.2 \\
5.05 \\
5.0\end{array}$ & $\begin{array}{l}4.6 \\
4.55 \\
4.45 \\
5.0 \\
5.0\end{array}$ & $\begin{array}{l}4.5 \\
5.05 \\
4.85 \\
4.75 \\
4.7\end{array}$ \\
\hline
\end{tabular}


Daily gage height, in feet, of Cuyahoga River at Independence, Ohio, for 1906-Cont'd.

\begin{tabular}{|c|c|c|c|c|c|c|c|c|}
\hline Day. & . & Jan. & Feb. & Mar. & Apr. & May. & June. & July. \\
\hline $\begin{array}{l}21 \ldots \ldots \\
22, \ldots \ldots \\
24 \ldots \ldots \\
25 \ldots \ldots\end{array}$ & & $\begin{array}{l}7.0 \\
7.55 \\
8.25 \\
7.6 \\
6.9\end{array}$ & $\begin{array}{l}5.4 \\
8.0 \\
7.35 \\
6.75 \\
6.6\end{array}$ & $\begin{array}{l}5.1 \\
5.1 \\
5.1 \\
5.5 \\
5.45\end{array}$ & $\begin{array}{l}5.3 \\
5.15 \\
5.5 \\
5.5 \\
5.4\end{array}$ & $\begin{array}{l}4.8 \\
4.9 \\
4.95 \\
4.9 \\
4.85\end{array}$ & $\begin{array}{l}4.9 \\
4.85 \\
4.75 \\
4.6 \\
4.4\end{array}$ & 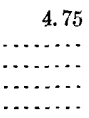 \\
\hline $\begin{array}{l}26 \ldots \ldots \\
27 \ldots \ldots \\
28, \ldots \\
29 \\
30 \ldots \ldots \\
31 \ldots \ldots \\
31\end{array}$ & & $\begin{array}{l}6.3 \\
5.85 \\
5.6 \\
5.45 \\
5.3 \\
5.25\end{array}$ & \begin{tabular}{|c|}
6.3 \\
5.9 \\
5.65 \\
$\cdots$ \\
$\cdots$ \\
$\cdots$ \\
$\cdots$ \\
$\cdots$
\end{tabular} & \begin{tabular}{c|}
5.3 \\
15.9 \\
14.4 \\
11.5 \\
11.9 \\
12.15
\end{tabular} & $\begin{array}{l}5.5 \\
5.5 \\
5.4 \\
5.2 \\
5.15 \\
-\ldots .\end{array}$ & $\begin{array}{l}4.9 \\
4.8 \\
4.5 \\
4.85 \\
4.8 \\
4.55\end{array}$ & $\begin{array}{l}4.8 \\
4.75 \\
4.55 \\
4.55 \\
4.6\end{array}$ & $\begin{array}{l}\cdots \\
\cdots \\
\cdots\end{array}$ \\
\hline
\end{tabular}

NoTE. - The rating table published for 1905 will give approximate results if applied to the above gage heights.

\section{LAKE ONTARIO DRAINAGE.}

\section{GENERAL FEATURES.}

In the northwestern part of the State of New York, between Niagara and St. Lawrence rivers, is an area aggregating 12,400 square miles drained by streams which flow into Lake Ontario. The divide which controls this drainage is very irregular. Extending to the south and southeast from Fort Niagara, it passes around the headwaters of the Genesee a short distance into Pennsylvania; thence reentering New York it runs southward and eastward from the interior group of lakes, turns to the north, encircles the sources of Black River, turns again to the west, and descends to the lake. The country thus included is level or gently undulating in the counties bordering the lake, but farther south it becomes more rolling, and a series of ridges, gradually increasing in height, stretch down between Cayuga and Seneca and their companion lakes, finally becoming merged with the elevated, broken country forming the principal divide, the abrupt slopes of which attain altitudes of from 2,000 to 2,500 feet about the headwaters of the Genesee.

The easterly or Black River lobe of the drainage basin receives the run-off from the southwestern slope of the Adirondack Mountainslargely a rugged and forest-covered area receiving heavy precipitation, especially in the winter.

The principal streams of the area are the Oswego, formed by the union of Seneca and Oneida rivers, which drain the chain of lakes in central New York, and Genesee, Salmon, and Black rivers.

\section{GENESEE RIVER BASIN.}

\section{DESCRIPTION OF BASIN.}

Genesee River rises in Potter County, Pa., 8 or 10 miles south of the New York-Pennsylvania boundary, flows northwestward for about 32 miles by general course, then turns to the northeast, and empties into 
Lake Ontario 7 miles north of Rochester. The entire length of the stream, following bends, is about 135 miles, and the drainage area is 2,496 square miles.

In the 39 miles between Belmont, in central Allegany County, and Portage, in southwestern Livingston County, the fall of the water surface is 253 feet, an average of 6.4 feet per mile. At Portage the river plunges down in three magnificent falls, and thence nearly to Mount Morris flows at the bottom of a deep gorge. From Mount Morris to Rochester the valley is broad and open and the stream is bordered by meadows subject to occasional overflow. At Rochester there is another abrupt descent over three heavy falls, amounting to about 260 feet within the city.

The series of remarkable lakes tributary to the Oswego basin is continued westward into the basin of the Genesee and includes Conesus, Hemlock, Canadice, and Honeoye lakes. These lakes serve as natural reservoirs and have inlets draining considerable areas at their upper ends. The slopes adjacent to the lakes themselves are narrow and steep and are drained by gulleys and torrential brooks. The area below the lakes is rolling and the soil is rich and extensively cultivated. The areas and elevations of these lakes are shown in the following table:

Areas and elevations of lakes in Genesee Raver basin. ${ }^{a}$

\begin{tabular}{|c|c|c|c|c|}
\hline Lake. & $\begin{array}{c}\text { Fleva- } \\
\text { tion. }\end{array}$ & $\begin{array}{c}\text { Water- } \\
\text { surface } \\
\text { area. }\end{array}$ & $\begin{array}{c}\text { Drainage } \\
\text { area. }\end{array}$ & $\begin{array}{l}\text { Per cent } \\
\text { water } \\
\text { surface. }\end{array}$ \\
\hline & Feet. & Sq. miles. & Sq. miles. & \\
\hline Hemlock Lake. . & 896 & 2.8 & 46.8 & 6.12 \\
\hline Canadice Lake. . & 1,092 & .7 & 12.6 & 5.57 \\
\hline Honeove Lake............... & 800 & 2.5 & 39.6 & 6.41 \\
\hline
\end{tabular}

$a$ These lake basins are shown on the Honeoye, Canandaigua, Naples, and Wayland topographic atlas sheets of the United States Geological Survey, from which the areas have been taken, with the exception of those for Hemlock and Canadice lakes, which a re from surveys for the Rochester waterworks.

Above all the private dams at Rochester the State has a dam for diverting water to the Erie Canal, and in the basin of Black Creek, one of the upper tributaries of the Genesee from the west, are two reservoirs, owned by the State, also used for the benefit of the Erie Canal.

Cuba reservioir, on the Genesee-Allegheny divide, receives the drainage from a tributary area of 26.6 square miles. The storage volume is $454,000,000$ cubic feet. The overflow from this reservoir enters Allegheny River. The storage water may be turned into the summit level of the abandoned Genesee Valley Canal and thence into Genesee River. 


\section{genesee RIVER AND CANASERAga CREEK NEAR MOUNT MORRIS,} N. $\mathbf{Y}$.

This station was established May 22, 1903, and was discontinued April 30, 1906. It was located at the highway bridge near Mount Morris, a short distance below the inflow of Canaseraga Creek. The conditions at this station and the bench marks are described in WaterSupply Paper No. 170, page 65, where are given also references to publications that contain data for previous years.

Discharge measurements of Genesee River near Mount Morris, N. $\dot{Y}$, in 1906.

\begin{tabular}{|c|c|c|c|c|c|}
\hline Date. & Hydrographer. & Width. & $\begin{array}{l}\text { Area of } \\
\text { section. }\end{array}$ & $\begin{array}{c}\text { Gage } \\
\text { height. }\end{array}$ & Discharge. \\
\hline February $12 a .$. & C. C. Covert. & $\begin{array}{c}\text { Feet. } \\
118\end{array}$ & $S q \cdot f t$. & $\begin{array}{l}\text { Feet. } \\
5.75\end{array}$ & $S e c .-f t$. \\
\hline February $13 a$. & ..... do....... & 118 & 290 & 5.78 & 479 \\
\hline Fehruary $16 a$. & .....do. & 127 & 373 & 6.00 & 525 \\
\hline $\operatorname{March} 29 . . . . .$. & .....do. & 171 & 1,640 & 13.90 & 5,420 \\
\hline March 30. & do. & 166 & 1,500 & 13.10 & 5,780 \\
\hline March 31 .. & .....do... & 193 & 2,660 & 19.05 & 10,800 \\
\hline March 31. & .... do. & 193 & 2,630 & 18.85 & 10,200 \\
\hline April 1.. & …do. & 185 & 1,750 & 14.33 & 5,920 \\
\hline April $2 \ldots$ & .....do.... & $\cdot 163$ & 1,210 & 11.60 & 4,360 \\
\hline April $3 \ldots$ & .....do... & 161 & 1,050 & 10.50 & 3,930 \\
\hline April $4 .$. & ....do.... & 161 & 1,120 & 10.85 & 4,460 \\
\hline April 14.. & ....do... & 1.53 & 864 & 9.38 & 3,080 \\
\hline April 21. & do. & 129 & 502 & 6.89 & 1,660 \\
\hline April $22 .$. & do. & 127 & 460 & 6.60 & 1,520 \\
\hline April $23 .$. & ..do.. & 127 & 504 & 6.90 & 1.740 \\
\hline September 15 . & ....do... & 70 & 191 & 4.15 & 238 \\
\hline
\end{tabular}

a Measurements made under ice cover, average thickness of ice, 0.49 foot, 0.41 foot, and 0.68 foot, respectively. Gage height to bottom of ice, 5.36 feet, 5.47 feet, and 5.42 feet, respectively.

Daily gage height, in feet, of Genesee River near Mount Morris, N. Y., for 1906.

\begin{tabular}{|c|c|c|c|c|c|c|c|c|c|}
\hline Day. & Jan. & Feb. & Mar. & Apr. & Day. & Jan. & Feb. & Mar. & Apr. \\
\hline 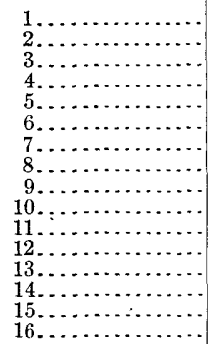 & $\begin{array}{l}8.2 \\
7.3 \\
6.8 \\
7.2 \\
9.7 \\
7.7 \\
6.3 \\
6.1 \\
7.2 \\
9.0 \\
8.8 \\
8.9 \\
8.3 \\
7.7 \\
7.55 \\
7.05\end{array}$ & $\begin{array}{l}6.4 \\
5.8 \\
7.7 \\
7.5 \\
7.35 \\
7.1 \\
6.65 \\
6.5 \\
6.4 \\
6.3 \\
6.05 \\
5.75 \\
5.55 \\
5.95 \\
6.0 \\
5.8\end{array}$ & $\begin{array}{l}6.65 \\
6.85 \\
6.3 \\
8.25 \\
8.0 \\
6.1 \\
5.9 \\
5.7 \\
5.5 \\
5.5 \\
5.25 \\
5.25 \\
5.25 \\
5.05 \\
5.0 \\
5.1\end{array}$ & $\begin{array}{l}13.85 \\
11.2 \\
10.3 \\
10.5 \\
13.4 \\
12.35 \\
11.45 \\
9.95 \\
9.55 \\
13.2 \\
14.1 \\
11.7 \\
10.35 \\
9.35 \\
10.55 \\
11.1\end{array}$ & $\begin{array}{l}17 \ldots \ldots \\
18 \ldots \ldots \\
19 \ldots \ldots \\
20 \ldots \ldots \\
21 \ldots \ldots \\
22 \ldots \ldots \\
23 \ldots \ldots \\
24 \ldots \ldots \\
25 \ldots \ldots \\
26 \ldots \ldots \\
27 \ldots \ldots \\
28 \ldots \ldots \\
29 \ldots \ldots \\
30 \ldots \ldots \\
31 \ldots \ldots \\
\end{array}$ & $\begin{array}{l}8.95 \\
7.95 \\
7.2 \\
6.55 \\
12.05 \\
16.25 \\
15.45 \\
15.3 \\
10.5 \\
8.35 \\
7.45 \\
7.0 \\
6.7 \\
6.3 \\
6.15\end{array}$ & 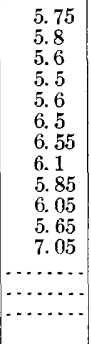 & $\begin{array}{l}4.95 \\
4.8 \\
4.8 \\
5.9 \\
5.15 \\
5.0 \\
5.0 \\
4.7 \\
4.85 \\
5.05 \\
9.1 \\
21.43 \\
14.7 \\
13.5 \\
18.45\end{array}$ & $\begin{array}{l}9.45 \\
8.4 \\
7.65 \\
7.2 \\
6.8 \\
6.6 \\
6.8 \\
6.5 \\
6.25 \\
5.95 \\
5.75 \\
5.5 \\
5.5 \\
5.65\end{array}$ \\
\hline
\end{tabular}

NoTE.-River frozen over from February 1 to March 20, approximately. During frozen period gage readings were taken to water surface through a hole cut in ice. Ice averaged from 0.2 to 0.6 foot thick at

gage and from 0.3 to 0.8 foot thick 200 feet below.
This station has backwater conditions during the spring floods; also considerable water flows around the left-hand end of the bridge above gage height 18.0 feet. 
Rating table for Genesee River near Mount Morrs, N. Y., for 1906.

\begin{tabular}{|c|c|c|c|c|c|c|c|}
\hline $\begin{array}{c}\text { Gage } \\
\text { height. }\end{array}$ & $\begin{array}{c}\text { Dis- } \\
\text { charge. }\end{array}$ & $\begin{array}{c}\text { Gage } \\
\text { height. }\end{array}$ & $\begin{array}{c}\text { Dis- } \\
\text { charge. }\end{array}$ & $\begin{array}{c}\text { Gage } \\
\text { height. }\end{array}$ & $\begin{array}{c}\text { Dis- } \\
\text { charge. }\end{array}$ & $\begin{array}{c}\text { Gage } \\
\text { height. }\end{array}$ & $\begin{array}{c}\text { Dis- } \\
\text { charge }\end{array}$ \\
\hline $\begin{array}{r}\text { Feet. } \\
4.70 \\
4.80 \\
4.90 \\
5.00 \\
5.10 \\
5.20 \\
5.30 \\
5.40 \\
5.50 \\
5.60 \\
5.70 \\
5.80 \\
5.90 \\
6.00\end{array}$ & $\begin{array}{r}\text { Sec. } f t . \\
490 \\
535 \\
580 \\
625 \\
675 \\
725 \\
775 \\
830 \\
885 \\
940 \\
995 \\
1,050 \\
1,105 \\
1,160\end{array}$ & $\begin{array}{r}\text { Feet. } \\
6.10 \\
6.20 \\
6.30 \\
6.40 \\
6.50 \\
6.60 \\
6.70 \\
6.80 \\
6.90 \\
7.00 \\
7.10 \\
7.20 \\
7.30 \\
7.40\end{array}$ & $\begin{array}{r}\text { Sec.-ft. } \\
1,215 \\
1,270 \\
1,325 \\
1,380 \\
1,435 \\
1,490 \\
1,550 \\
1,610 \\
1,670 \\
1,730 \\
1,790 \\
1,850 \\
1,910 \\
1,970\end{array}$ & $\begin{array}{c}\text { Feet. } \\
7.50 \\
7.60 \\
7.70 \\
7.80 \\
7.90 \\
8.00 \\
8.20 \\
8.40 \\
8.60 \\
8.80 \\
9.00 \\
9.20 \\
9.40 \\
9.60\end{array}$ & $\begin{array}{r}\text { Sec. }-f t . \\
2,030 \\
2,090 \\
2,155 \\
2,220 \\
2,285 \\
2,350 \\
2,480 \\
2,610 \\
2,740 \\
2,870 \\
3,000 \\
3,140 \\
3,280 \\
3,420\end{array}$ & $\begin{array}{r}\text { Feet. } \\
9.80 \\
10.00 \\
10.20 \\
10.40 \\
10.60 \\
10.80 \\
11.00 \\
12.00 \\
13.00 \\
14.00 \\
15.00 \\
16.00 \\
17.00 \\
18.00\end{array}$ & $\begin{array}{r}\text { Sec.-ft. } \\
3,560 \\
3,700 \\
3,840 \\
3,980 \\
4,120 \\
4,270 \\
4,420 \\
5,170 \\
5,960 \\
6,760 \\
7,560 \\
8,360 \\
9,160 \\
9,960\end{array}$ \\
\hline
\end{tabular}

Note.-The above table is applicable only for open-channel conditions. It is based on discharge measurements made during 1906 and is fairly well defined.

Monthly discharge of Genesee River near Mount Morris, N. Y., for 1906.

[Drainage area, 1,070 square miles.]

\begin{tabular}{|c|c|c|c|c|c|}
\hline \multirow[b]{2}{*}{ Month. } & \multicolumn{3}{|c|}{ Discharge in second-feet. } & \multicolumn{2}{|c|}{ Run-off. } \\
\hline & Maximum. & Minimum. & Mean. & $\begin{array}{l}\text { Sec.-ft. per } \\
\text { sq. mile. }\end{array}$ & $\begin{array}{l}\text { Depth in } \\
\text { inches. }\end{array}$ \\
\hline 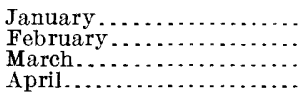 & $\begin{array}{r}8,560 \\
1,080 \\
11,000 \\
6,840\end{array}$ & $\begin{array}{r}1,220 \\
442 \\
268 \\
885\end{array}$ & $\begin{array}{r}2,830 \\
650 \\
1,690 \\
3,290\end{array}$ & $\begin{array}{l}2.64 \\
.607 \\
1.58 \\
3.07\end{array}$ & $\begin{array}{r}3.04 \\
.63 \\
1.82 \\
3.42\end{array}$ \\
\hline
\end{tabular}

NotE.-Discharges February 1 to March 20 have been taken as 50 per cent of the open-water flow: backwater assumed March 28, discharge corrected.

Values are rated as follows: January and April, good; March, fair; February, approximate.

Discharge measurements of Canaseraga Creek near Mount Morris, N. Y., in 1906.

\begin{tabular}{|c|c|c|c|c|c|}
\hline Date. & Hydrographer. & Width. & $\begin{array}{l}\text { Area of } \\
\text { section. }\end{array}$ & $\begin{array}{c}\text { Gage = } \\
\text { height. }\end{array}$ & $\begin{array}{c}\text { Dis- } \\
\text { charge. }\end{array}$ \\
\hline $\begin{array}{l}\text { March } 29 . . \\
\text { March } 30 . . \\
\text { March } 31 a . \\
\text { April } 2 \ldots . . \\
\text { April } 3 \ldots \ldots \\
\text { April } 21 . . .\end{array}$ & 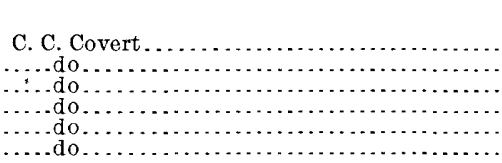 & $\begin{array}{r}\text { Feet. } \\
84 \\
84 \\
94 \\
81 \\
75 \\
66\end{array}$ & $\begin{array}{r}S q \cdot f t . \\
500 \\
456 \\
900 \\
368 \\
310 \\
142\end{array}$ & $\begin{aligned} & \text { Feet. } \\
& 9.22 \\
& 8.90 \\
& 13.55 \\
& 7.85 \\
& 7.00 \\
& 4.45\end{aligned}$ & $\begin{array}{r}\text { Sec.-ft. } \\
1,880 \\
1,620 \\
1,670 \\
1,430 \\
1,150 \\
478\end{array}$ \\
\hline
\end{tabular}

$a$ Backwater from Genesec River.

GENESEE RIVER AT HIGI DAM NEAR MOUNT MORRIS, N. Y.

A gaging station has been established at the dam of the Mount Morris Water Power Company, in the village of Mount Morris, N. Y., and readings have been taken regularly twice each day, by John McAstocker, since September 1, 1905.

The dam is of masonry construction, having a horizontal crest of open cross section 255 feet long. There are two waste ways, having crests each 12 inches wide and 18.0 feet and 17.9 feet long, respectively, closed by stop planks to about 2 feet above the main crest; also one short spillway with crest 6 inches wide and 17 feet long and about 1 foot higher than the wasteways. The dam and the spillways 
are separated by masonry piers 6 feet, 8 feet, and 6 feet in width, respectively.

A portion of the flow is diverted through a section of the old Genesee Valley Canal, which is utilized as a headrace, the power being used to drive a number of mills and factories. In order to determine the amount of this diversion, a gage has been placed in the tailrace below the mills. It is read twice each day by F. M. Goff, electrical engineer in the employ of the power company. A number of meter measurements have been made, and a rating curve to determine the daily flow through the canal is partly developed. When the complete curve is developed, the data will be published.

\section{GENESEE RIVER AT ROCHESTER, N. Y.}

This station was established February 9, 1904. It is located at the Elmwood Avenue Bridge, in Rochester, N. Y. The conditions at this station $^{a}$ and the bench marks are described in Water-Supply Paper No. 170, page 69, where are given also references to publications that contain data for previous years.

Discharge measurements of Genesee River at Rochester, N. Y., in 1904-1906.

\begin{tabular}{|c|c|c|c|c|c|}
\hline Date. & Hydrographer. & Width. & $\begin{array}{l}\text { A rea of } \\
\text { section. }\end{array}$ & $\begin{array}{c}\text { Gage } \\
\text { height. }\end{array}$ & Discharge. \\
\hline $\begin{array}{r}1904 . \\
\text { July } 20 \ldots\end{array}$ & C. C. Covert & Feet. & $s q . f t$ & $\begin{array}{l}\text { Feet. } \\
\quad 1.30\end{array}$ & Sec.-ft. \\
\hline August 9 . & E. H. Fisher. & & $\begin{array}{r}1,010 \\
976\end{array}$ & 1.18 & 614 \\
\hline August 10 . & ..... do... & & 957 & 1.10 & 589 \\
\hline August 1 & ...do. & & 944 & 1.15 & 594 \\
\hline August 1 & .... do. & .. & 963 & 1.20 & 667 \\
\hline August 15. & ....do. & & 973 & 1. 10 & 587 \\
\hline Augus & $d$ & & 972 & 1.22 & 703 \\
\hline August 30 & ..... do. & .. & 916 & 1.07 & 554 \\
\hline September 17 & .....do.. & & 923 & 1.05 & 511 \\
\hline November $11 .$. & C. C. Covert & & 994 & 1.20 & 534 \\
\hline 1905 & & & & & \\
\hline March 22 & Covert and Weeks. & $\begin{array}{l}382 \\
382\end{array}$ & 4,220 & . $\begin{array}{r}10.00 \\
0.95\end{array}$ & $\begin{array}{l}24,700 \\
24,900\end{array}$ \\
\hline $\begin{array}{l}\text { March } 22 . \\
\text { March } 25 .\end{array}$ & ......do & $\begin{array}{l}382 \\
382\end{array}$ & $\begin{array}{l}4,200 \\
4,300\end{array}$ & $\begin{array}{r}9.90 \\
10.20\end{array}$ & $\begin{array}{l}24,900 \\
25,500\end{array}$ \\
\hline Marc & .....do do & 382 & 4,200 & 9.92 & 25,200 \\
\hline March 2 & ..do & 382 & 4,160 & 9.82 & 24,800 \\
\hline Mare & $\ldots$ do & 382 & 4,050 & 9.50 & 23,600 \\
\hline Mar & ..d & 382 & 3,960 & 9.08 & 22,500 \\
\hline & -4 & & 2,140 & & 6,530 \\
\hline April 3 & $\ldots . \mathrm{dc}$ & 37 & 1,890 & 3.50 & 5,200 \\
\hline April 4 & .....do.. & 372 & 1,820 & 3.28 & 4,580 \\
\hline May 28 & C. C. Covert. & 352 & 974 & 1.11 & 441 \\
\hline & & & & & \\
\hline Februs & Covert and Weeks.. & 306 & 1,710 & 1. 40 & $\begin{array}{l}728 \\
894\end{array}$ \\
\hline $\begin{array}{l}\text { February } 15 \\
\text { March } 28 \ldots\end{array}$ & Weeks and Casey.. & $\begin{array}{l}360 \\
383\end{array}$ & $\begin{array}{l}1,020 \\
3,160\end{array}$ & $\begin{array}{l}1.53 \\
6.85\end{array}$ & $\begin{array}{r}894 \\
14,100\end{array}$ \\
\hline $\begin{array}{l}\text { March } 28 \ldots \\
\text { March } 29 .\end{array}$ & ..... do . . . . . . & 38 & 3,320 & $\begin{array}{l}7.003 \\
7.32\end{array}$ & 15,100 \\
\hline Marc & ......do & & 2,680 & 5.64 & 9,580 \\
\hline Mar & $\ldots \mathrm{dc}$ & 38 & 2,860 & 6.06 & 12,400 \\
\hline Mar & .....d d & 383 & 2,940 & 6.31 & 13,300 \\
\hline April 1. & .... do & 384 & 3,040 & 6.60 & 14,200 \\
\hline & . & 383 & 3,050 & 6.36 & 13,000 \\
\hline April 2 . & & 37 & 2, & 5.08 & 8,830 \\
\hline A pril 2. & $\ldots . \mathrm{d}$ & 375 & 2,330 & 4.70 & 7,160 \\
\hline April 3. & $\ldots \mathrm{dc}$ & 374 & 2,100 & 4. 10 & 5,860 \\
\hline
\end{tabular}

a The gage datum is 245.59 feet above the city topographic datum, to which gage heights published for 1904 refer.

$b$ Measured under ice cover, about one-fourth mile above regular section; gage height to top of ice, 1.50 feet; a verage thickness of ice, 0.50 foot.

$c$ Measured under ice cover at regular section; gage height to top of ice, 1.63 feet; average thickness of ice, 0.46 foot; some needle ice. 
Daily gage height, in feet, of Genesee River at Rochester, N. Y., for 1906.

\begin{tabular}{|c|c|c|c|c|c|c|c|c|c|c|c|c|}
\hline Day. & Jan. & Feb. & Mar. & Apr. & May. & June. & July. & Aug. & Sept. & Oct. & Nov. & Dec. \\
\hline $\begin{array}{l}1 \ldots \ldots \\
2 \ldots \\
3 \ldots \\
4 \ldots \\
5 \ldots\end{array}$ & $\begin{array}{l}3.0 \\
2.9 \\
2.9 \\
2.5 \\
2.3\end{array}$ & $\begin{array}{l}2.0 \\
2.0 \\
2.0 \\
2.0 \\
2.0\end{array}$ & $\begin{array}{l}1.7 \\
2.0 \\
1.5 \\
1.9 \\
2.7\end{array}$ & $\begin{array}{l}6.5 \\
5.6 \\
4.2 \\
3.8 \\
4.0\end{array}$ & $\begin{array}{l}1.8 \\
1.9 \\
2.2 \\
3.5 \\
3.0\end{array}$ & $\begin{array}{l}2.4 \\
2.0 \\
1.9 \\
1.8 \\
1.7\end{array}$ & $\begin{array}{l}1.5 \\
1.4 \\
1.4 \\
2.2 \\
2.6\end{array}$ & $\begin{array}{l}1.1 \\
1.2 \\
1.3 \\
1.2 \\
1.6\end{array}$ & $\begin{array}{l}1.3 \\
1.2 \\
1.1 \\
1.1 \\
1.1\end{array}$ & $\begin{array}{l}1.2 \\
1.3 \\
1.6 \\
1.4 \\
1.4\end{array}$ & $\begin{array}{l}3.0 \\
3.0 \\
3.0 \\
2.9 \\
2.8\end{array}$ & $\begin{array}{l}2.06 \\
2.05 \\
2.04 \\
2.03 \\
2.02\end{array}$ \\
\hline $\begin{array}{c}6 \ldots \\
7 \ldots \\
8 \ldots \\
9 \ldots \\
10 . \\
\end{array}$ & $\begin{array}{l}3.3 \\
2.9 \\
2.4 \\
2.4 \\
2.3\end{array}$ & $\begin{array}{l}1.9 \\
1.9 \\
1.8 \\
1.8 \\
1.8\end{array}$ & $\begin{array}{l}3.1 \\
2.1 \\
2.0 \\
1.9 \\
1.8\end{array}$ & $\begin{array}{l}4.9 \\
4.6 \\
4.0 \\
3.6 \\
5.0\end{array}$ & $\begin{array}{l}3.1 \\
2.9 \\
2.5 \\
2.2 \\
2.1\end{array}$ & $\begin{array}{l}1.5 \\
2.7 \\
2.5 \\
2.7 \\
1.9\end{array}$ & $\begin{array}{l}2.0 \\
1.8 \\
1.6 \\
1.4 \\
1.4\end{array}$ & $\begin{array}{l}1.7 \\
1.6 \\
1.6 \\
1.7 \\
1.7\end{array}$ & $\begin{array}{l}1.1 \\
1.0 \\
1.0 \\
1.0 \\
1.0\end{array}$ & $\begin{array}{l}1.5 \\
2.5 \\
3.5 \\
2.8 \\
2.4\end{array}$ & $\begin{array}{l}2.6 \\
2.4 \\
2.3 \\
2.1 \\
2.0\end{array}$ & $\begin{array}{l}2.01 \\
6.02 \\
6.08 \\
5.0 \\
3.06\end{array}$ \\
\hline & $\begin{array}{l}2.1 \\
1.9 \\
2.2 \\
1.9 \\
1.7\end{array}$ & $\begin{array}{l}1.7 \\
1.7 \\
1.4 \\
1.4 \\
1.5\end{array}$ & $\begin{array}{l}1.6 \\
1.3 \\
1.6 \\
1.5 \\
1.6\end{array}$ & $\begin{array}{l}5.9 \\
5.5 \\
4.5 \\
3.8 \\
3.5\end{array}$ & $\begin{array}{l}2.4 \\
2.3 \\
2.1 \\
2.0 \\
2.2\end{array}$ & $\begin{array}{l}1.8 \\
1.8 \\
1.8 \\
1.7 \\
1.5\end{array}$ & $\begin{array}{l}1.3 \\
1.2 \\
1.1\end{array}$ & $\begin{array}{l}1.5 \\
1.6 \\
1.8 \\
1.6 \\
1.5\end{array}$ & $\begin{array}{l}1.0 \\
1.0 \\
1.0\end{array}$ & $\begin{array}{l}2.5 \\
2.8 \\
2.6 \\
2.2 \\
2.1\end{array}$ & & $\begin{array}{l}3.01 \\
4.04 \\
3.03 \\
3.0 \\
3.02\end{array}$ \\
\hline 16 & $\begin{array}{l}1.9 \\
2.2 \\
2.3 \\
2.2 \\
2.1\end{array}$ & $\begin{array}{l}2.0 \\
2.0 \\
1.8 \\
1.6 \\
1.4\end{array}$ & \begin{tabular}{l|}
1.5 \\
1.4 \\
1.4 \\
1.4 \\
1.3
\end{tabular} & $\begin{array}{l}3.3 \\
3.0 \\
2.8\end{array}$ & $\begin{array}{l}2.2 \\
2.1 \\
2.1 \\
2.5 \\
2.3\end{array}$ & $\begin{array}{l}1.5 \\
1.5 \\
1.8 \\
1.9 \\
1.9\end{array}$ & $\begin{array}{l}1.4 \\
1.3\end{array}$ & $\begin{array}{l}1.5 \\
1.4 \\
1.3 \\
1.2 \\
1.1\end{array}$ & $\begin{array}{l}1.0 \\
1.0 \\
1.0 \\
1.0 \\
1.0\end{array}$ & $\begin{array}{l}2.0 \\
1.9 \\
1.8 \\
1.7 \\
1.9\end{array}$ & & $\begin{array}{l}\text { 6.0 } \\
5.06 \\
4.0 \\
3.05 \\
3.0\end{array}$ \\
\hline $5 \ldots$. & $\begin{array}{l}2.7 \\
4.9 \\
5.6 \\
5.3 \\
4.9\end{array}$ & $\begin{array}{l}1.5 \\
1.8 \\
2.0 \\
2.0 \\
2.1\end{array}$ & $\begin{array}{l}1.5 \\
1.6 \\
1.4 \\
1.6 \\
1.6\end{array}$ & $\begin{array}{l}2.5 \\
2.3 \\
2.2 \\
2.3 \\
2.2\end{array}$ & $\begin{array}{l}2.0 \\
1.8 \\
1.7 \\
1.6 \\
1.9\end{array}$ & $\begin{array}{l}1.7 \\
1.6 \\
1.5 \\
1.5 \\
1.5\end{array}$ & $\begin{array}{l}1.2 \\
1.1\end{array}$ & $\begin{array}{l}1.1 \\
1.4 \\
1.4 \\
1.8 \\
2.0\end{array}$ & $\begin{array}{l}1.0 \\
1.0 \\
1.3 \\
1.3 \\
1.4\end{array}$ & $\begin{array}{l}3.4 \\
3.1 \\
2.6 \\
2.5 \\
2.3\end{array}$ & & $\begin{array}{l}2.06 \\
2.01 \\
2.1 \\
2.0 \\
3.0\end{array}$ \\
\hline $31 \ldots$ & $\begin{array}{l}3.5 \\
2.7 \\
2.4 \\
2.1 \\
2.4 \\
2.1\end{array}$ & $\begin{array}{l}2.1 \\
1.8 \\
1.6 \\
\cdots\end{array}$ & $\begin{array}{l}1.5 \\
2.4 \\
6.0 \\
7.3 \\
5.8 \\
6.0\end{array}$ & $\begin{array}{l}2.1 \\
2.0 \\
1.9 \\
1.8 \\
1.8\end{array}$ & $\begin{array}{l}2.2 \\
1.9 \\
1.9 \\
3.2 \\
2.6 \\
2.2\end{array}$ & $\begin{array}{l}1.5 \\
1.5 \\
1.4 \\
1.3 \\
1.5\end{array}$ & $\begin{array}{l}1.2 \\
1.2\end{array}$ & $\begin{array}{l}1.8 \\
1.5 \\
1.4 \\
1.4 \\
1.5 \\
1.3\end{array}$ & $\begin{array}{l}1.3 \\
1.3 \\
1.1 \\
1.1 \\
1.1\end{array}$ & $\begin{array}{l}3.6 \\
3.3 \\
2.6 \\
2.4 \\
2.5 \\
2.5\end{array}$ & $\begin{array}{c}3.04 \\
3.02 \\
3.00 \\
3.01 \\
2.08 \\
\cdots \\
\text {.... }\end{array}$ & $\begin{array}{l}3.2 \\
3.0 \\
2.8 \\
2.7 \\
2.3 \\
2.3\end{array}$ \\
\hline
\end{tabular}

Rating table for Genesee River at Rochester, N. Y., for 1904-1906.

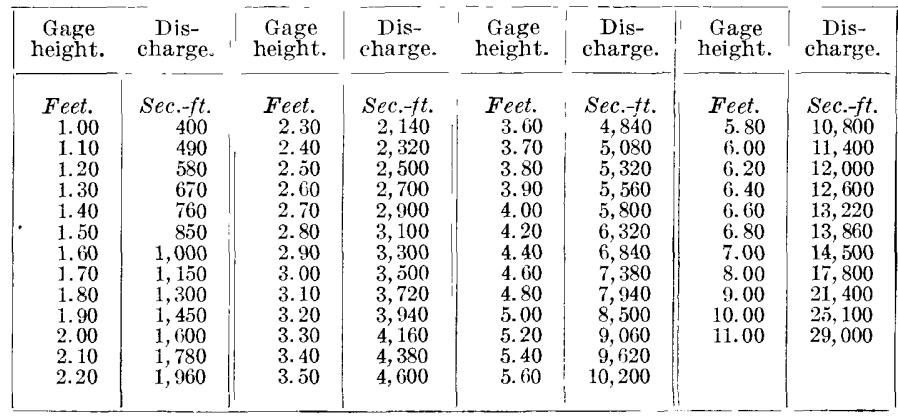

NotE.-The above table is applicable only for open-channel conditions. It is based on discharge measurements made during 1904-1906 and is well defined.

IRR $206-07-05$ 
Monthly discharge of Genesee River at Rochester, N. Y., for 1904-1906.

[Drainage area, 2,360 square miles.]

\begin{tabular}{|c|c|c|c|c|c|}
\hline \multirow[b]{2}{*}{ Month. } & \multicolumn{3}{|c|}{ Discharge in second-feet. } & \multicolumn{2}{|c|}{ Run-off. } \\
\hline & Maximum. & Minimum. & Mean. & $\begin{array}{l}\text { Sec.-ft. per } \\
\text { sq. mile. }\end{array}$ & $\begin{array}{l}\text { Depth in } \\
\text { inches. }\end{array}$ \\
\hline February $(9-12), 1904 . a$ & & & & 10.17 & \\
\hline $\begin{array}{l}\text { February }(9-12) \ldots \ldots \ldots \\
\text { March } 2-31 b \ldots \ldots \ldots\end{array}$ & $\begin{array}{l}31,800 \\
27,000\end{array}$ & $\begin{array}{r}14,500 \\
2,500\end{array}$ & $\begin{array}{l}24,000 \\
12,900\end{array}$ & $\begin{array}{r}10.17 \\
5.47\end{array}$ & $\begin{array}{l}1.51 \\
6.10\end{array}$ \\
\hline April $b$ & 13,200 & 4,160 & 7,460 & 3.16 & 3. 53 \\
\hline May...... & 7,660 & 1,450 & 3,160 & 1.34 & 1.54 \\
\hline June. & 8,500 & 670 & 2,230 & .945 & 1.05 \\
\hline July..... & 3,100 & 670 & 1,310 & .555 & .64 \\
\hline August... & 1,150 & 400 & 634 & .269 & .31 \\
\hline September. & 850 & 400 & 523 & .222 & .25 \\
\hline October.... & 2,500 & 490 & 986 & .418 & .48 \\
\hline November............ & 760 & 490 & $\begin{array}{r}562 \\
570\end{array}$ & .238 & .27 \\
\hline December.............. & 13,200 & 490 & 1,570 & .665 & \\
\hline January $(1-27) \ldots \ldots$ & & & & & \\
\hline Mareh (18-31). & $\begin{array}{r}5,560 \\
25,900\end{array}$ & $\begin{array}{l}1,600 \\
1,960\end{array}$ & $\begin{array}{r}2,800 \\
20,200\end{array}$ & $\begin{array}{l}1.19 \\
8.56\end{array}$ & $\begin{array}{l}1.20 \\
4.46\end{array}$ \\
\hline April.......... & 13,200 & 2,320 & 4,150 & 1.76 & 1.96 \\
\hline May.......... & 2,140 & 1,300 & 1,460 & .619 & .71 \\
\hline June........ & 7,660 & 850 & 2,670 & 1.13 & 1.26 \\
\hline July.. & 4,380 & 715 & 1,340 & .568 & .65 \\
\hline August ..... & 3,720 & 535 & 1,230 & .521 & .60 \\
\hline September. & 850 & 400 & 580 & .246 & .27 \\
\hline October.... & 1,000 & 400 & 589 & .250 & .29 \\
\hline November... & 7,940 & 580 & 1,400 & .593 & .66 \\
\hline December... & 7,380 & 580 & 2,690 & 1.14 & 1.31 \\
\hline Janugry & & & & & \\
\hline $\begin{array}{l}\text { January .... } \\
\text { February... }\end{array}$ & $\begin{array}{r}10,200 \\
1,780\end{array}$ & $\begin{array}{r}1,150 \\
760\end{array}$ & $\begin{array}{l}3,250 \\
1,320\end{array}$ & $\begin{array}{l}1.38 \\
.559\end{array}$ & $\begin{array}{r}1.59 \\
.58\end{array}$ \\
\hline March.... & 15,500 & 670 & 2,680 & 1.14 & 1.31 \\
\hline April....... & 12,900 & 1,300 & 5,110 & 2.17 & 2. 42 \\
\hline May. & 4,600 & 1,000 & 2,130 & .902 & 1.04 \\
\hline June. . & 2,900 & 670 & 1,300 & .551 & .61 \\
\hline July..... & 2,700 & 400 & 783 & .332 & .38 \\
\hline August.... & 1,600 & 490 & 878 & .371 & .43 \\
\hline September. & 760 & 400 & 484 & .205 & .23 \\
\hline October..... & 4,840 & 580 & 2,280 & .966 & 1. 11 \\
\hline November. & 11,600 & 1,600 & 3,650 & 1. 55 & 1.72 \\
\hline December. & 11,600 & 1,600 & 4,070 & 1.72 & 1.98 \\
\hline The year. & 15,500 & 400 & 2,330 & .987 & 13.4 \\
\hline
\end{tabular}

$a$ Values for 1904 are rated as follows: February to May, good; June, July, October, and December, fair; August, September, and November, approximate.

$b$ Discharge interpolated for missing days.

$c$ Values for 1905 are rated as follows: January, May to A ugust, November, and December, fair; March and April, good; September and October, approximate.

$d$ Values for 1906 are rated as follows: January, A pril, November, and December, good; February, March, May to August, and October, fair; September, approximate.

CANADICE LAKE OUTLET NEAR HEMLOCK, N. Y.

This station is located at a weir constructed at the outlet at the foot of the lake by the city engineer's department of Rochester, N. Y., in February, 1903. The entire yield of the drainage basin passes this weir. The conditions at this station and the bench marks are described in Water-Supply Paper No. 170, page 71, where are given also references to publications that contain data for previous years. 
Monthly discharge of Canadice Lake outlet near IIemlock, N. Y., for 1906.

[Drainage area, 12.6 square miles.]

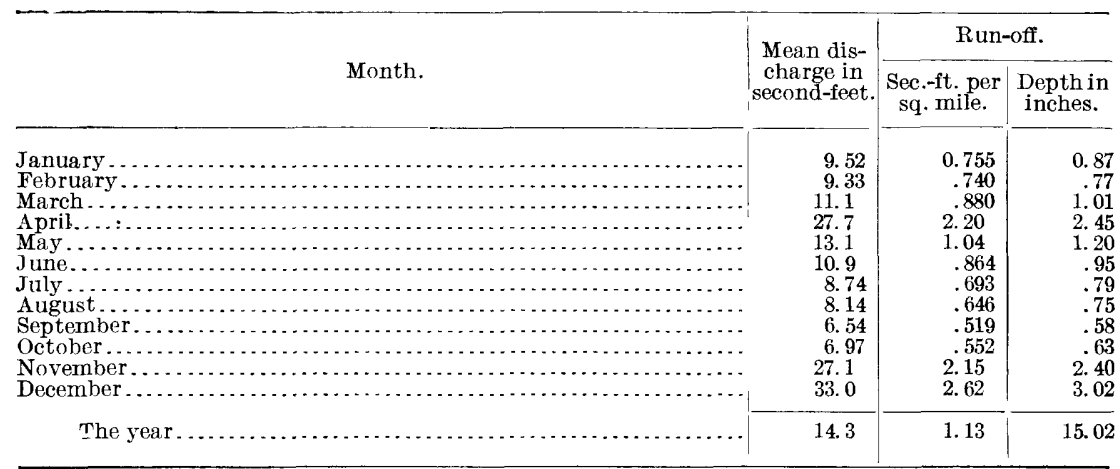

HONEOYE CREEK AT EAST RUSH, N. Y.

This station was established February 13, 1903, and was discontinued April 30, 1906. It was located at the gristmill dam in the village of East Rush. The conditions at this station and the bench marks are described in Water-Supply Paper No. 170, page 72, where are given also references to publications that contain data for previous years.

Daily discharge, in second-feet, of Honeoye Creek at East Rush, N. Y., for 1906.

\begin{tabular}{|c|c|c|c|c|c|c|c|c|c|}
\hline Day. & Jan. & Feb. & Mar. & Apr. & Day. & Jan. & Feb. & Mar. & Apr. \\
\hline 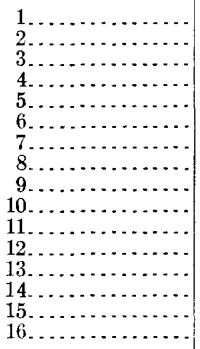 & $\begin{array}{r}84 \\
60 \\
\mathbf{5 2} \\
123 \\
141 \\
111 \\
\mathbf{7 7} \\
44 \\
44 \\
31 \\
29 \\
61 \\
88 \\
43 \\
\mathbf{5 4} \\
60\end{array}$ & $\begin{array}{l}84 \\
42 \\
42 \\
43 \\
42 \\
37 \\
33 \\
42 \\
40 \\
43 \\
25 \\
38 \\
39 \\
70 \\
70 \\
70\end{array}$ & $\begin{array}{r}60 \\
60 \\
148 \\
194 \\
172 \\
123 \\
84 \\
99 \\
70 \\
70 \\
77 \\
52 \\
52 \\
52 \\
52 \\
52\end{array}$ & $\begin{array}{r}527 \\
445 \\
329 \\
282 \\
553 \\
542 \\
505 \\
444 \\
541 \\
1,176 \\
764 \\
574 \\
497 \\
411 \\
366 \\
345\end{array}$ & 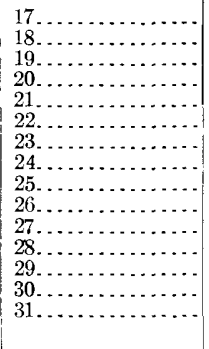 & $\begin{array}{r}60 \\
60 \\
84 \\
104 \\
169 \\
246 \\
321 \\
132 \\
84 \\
70 \\
70 \\
77 \\
60 \\
70 \\
84\end{array}$ & $\begin{array}{r}70 \\
77 \\
70 \\
70 \\
172 \\
196 \\
104 \\
148 \\
169 \\
172 \\
84 \\
60 \\
\\
\end{array}$ & $\begin{array}{r}60 \\
77 \\
44 \\
53 \\
74 \\
94 \\
70 \\
60 \\
25 \\
70 \\
1,107 \\
1,073 \\
512 \\
510 \\
1,023\end{array}$ & $\begin{array}{l}305 \\
301 \\
305 \\
229 \\
231 \\
219 \\
214 \\
179 \\
149 \\
149 \\
125 \\
131 \\
121 \\
131\end{array}$ \\
\hline
\end{tabular}

Note.-From January 1 to March 26 the discharge is approximate; the flow over crest of dam was obstructed by ice. 
Monthly discharge of Honeoye Creek at East Rush, N. Y., for 1906.

[Drainage area, 238 square miles.]

\begin{tabular}{|c|c|c|c|c|c|}
\hline \multirow[b]{2}{*}{ Month. } & \multicolumn{3}{|c|}{ Discharge in second-feet. } & \multicolumn{2}{|c|}{ Run-off. } \\
\hline & Maximum. & Minimum. & Mean. & $\begin{array}{l}\text { Sec-ft. per } \\
\text { sq. mile. }\end{array}$ & $\begin{array}{l}\text { Depth in } \\
\text { inches. }\end{array}$ \\
\hline 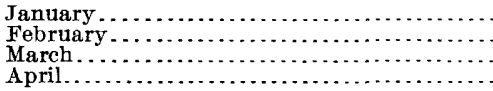 & $\begin{array}{r}321 \\
196 \\
1,110 \\
1,180\end{array}$ & $\begin{array}{r}29 \\
25 \\
25 \\
121\end{array}$ & $\begin{array}{l}90.0 \\
76.8 \\
202 \\
370\end{array}$ & $\begin{array}{c}0.378 \\
.323 \\
.848 \\
1.55\end{array}$ & $\begin{array}{r}0.44 \\
.34 \\
.98 \\
1.73\end{array}$ \\
\hline
\end{tabular}

NoTE.-Above values are rated as approximate.

\section{OSWEGO RIVER BASIN.}

\section{DESCRIPTION OF BASIN.}

Oswego River is formed by the union of Seneca and Oneida rivers about 12 miles northwest of Syracuse, N. Y., whence its course is northwestward to Oswego, where it enters Lake Ontario. The length of the river from the junction to the mouth is about 20.5 miles, and the drainage basin along this distance is a narrow strip of country, moderately rolling. Above the junction of Seneca and Oneida rivers the basin spreads out, attaining an extreme width east and west of about 100 miles and north and south of from 70 to 80 miles.

The most remarkable feature of the drainage basin is the chain of lakes stretching across its southern border. From west to east the principal lakes are, in order, Canandaigua, Keuka, Seneca, Cayuga, Owasco, Skaneateles, and Oneida. These seven lakes include a water surface of approximately 280 square miles, increased by four smaller lakes-Cross, Onondaga, Otisco, and Cazenovia-to about 295 square miles. The larger of the lakes, Oneida, Cayuga, and Seneca, are used for steam-towing navigation, having connection with the Erie and Oswego canals. Cayuga and Seneca lakes are noted for their depth and for the abrupt slopes of their beds The influence of the lakes on Oswego River is of the utmost importance in contributing to the steadiness of its flow.

A fall of 100 feet in the course of the main river is largely utilized by seven dams, which also partly canalize the stream. The intervening stretches are covered by the Oswego Canal, which draws its water supply from the river.

OSWEGO RIVER AT BATTLE ISLAND, N. Y.

This station was established September 14, 1900, and was discon. tinued April 30, 1906. It was located 3 miles above the mouth of the river and 0.6 mile below the State dam at Battle Island. The conditions at this station and the bench marks are described in Water- 
Supply Paper No. 170, page 74, where are given also references to publications that contain data for previous years.

Daily gage height, in feet, of Oswego River at Battle Island, N. Y., for 1906.

\begin{tabular}{|c|c|c|c|c|c|c|c|c|c|}
\hline Day. & Jan. & Feb. & Mar. & Apr. & Day. & Jan. & Feb. & Mar. & Apr. \\
\hline 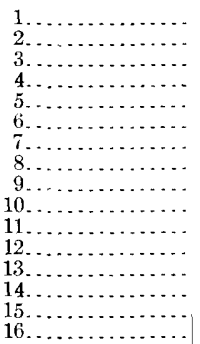 & $\begin{array}{l}5.9 \\
6.35 \\
6.65 \\
6.55 \\
6.4 \\
6.25 \\
5.75 \\
6.5 \\
6.6 \\
6.4 \\
5.8 \\
5.75 \\
5.5 \\
5.25 \\
5.7 \\
5.75\end{array}$ & $\begin{array}{l}6.05 \\
5.85 \\
5.0 \\
5.15 \\
5.15 \\
5.1 \\
5.25 \\
5.15 \\
5.0 \\
5.0 \\
4.7 \\
5.0 \\
4.92 \\
4.9 \\
4.82 \\
4.82\end{array}$ & $\begin{array}{l}5.15 \\
5.2 \\
5.05 \\
5.45 \\
5.92 \\
5.8 \\
5.8 \\
5.7 \\
5.65 \\
5.65 \\
5.0 \\
5.65 \\
5.5 \\
5.15 \\
5.0 \\
5.0\end{array}$ & $\begin{array}{l}7.4 \\
7.65 \\
7.5 \\
7.5 \\
7.5 \\
7.5 \\
7.4 \\
7.3 \\
7.8 \\
8.4 \\
8.3 \\
8.3 \\
8.2 \\
8.05 \\
7.95 \\
8.25\end{array}$ & $\begin{array}{l}17 \ldots \\
18 \ldots \\
19 \ldots \\
20 \ldots \\
21 \ldots \\
22 \ldots \\
23 \ldots \\
24 \ldots \\
25 \ldots \\
26 \ldots \\
27 \ldots \\
28 \ldots \\
29 \ldots \\
30 \ldots \\
31 \ldots\end{array}$ & $\begin{array}{l}5.8 \\
5.75 \\
5.8 \\
5.55 \\
5.45 \\
6.2 \\
6.7 \\
6.95 \\
6.9 \\
6.85 \\
6.6 \\
6.1 \\
6.4 \\
6.3 \\
6.15\end{array}$ & $\begin{array}{l}4.88 \\
4.68 \\
4.82 \\
4.82 \\
4.88 \\
4.88 \\
4.9 \\
4.85 \\
4.75 \\
5.5 \\
5.3 \\
5.1\end{array}$ & $\begin{array}{l}5.05 \\
7.05 \\
\ldots \ldots \\
\cdots \ldots . \\
\cdots \ldots . \\
\ldots \ldots . \\
\ldots \ldots \\
6.2 \\
6.8 \\
7.05 \\
7.2 \\
7.3\end{array}$ & $\begin{array}{l}8.05 \\
8.0 \\
8.0 \\
7.85 \\
7.78 \\
6.55 \\
6.95 \\
6.8 \\
6.65 \\
6.5 \\
6.45 \\
6.4 \\
6.15 \\
6.55\end{array}$ \\
\hline
\end{tabular}

NoTE.-Gage height below 5.0 feet on March 18 and March 20 to 26 . River does not freeze over entirely at gage; shore ice extends from 10 to 50 feet out, lea ving an open channel in center of stream. The frozen period is affected by needle ice at times. Ice period for 1906 , from January 31 to February 26 , ice 0.5 to 0.8 foot thick at gage. Backwater from ice jam below gage on February 26 to 28 . During frozen period readings were taken to water surface through a hole eut in ice.

Rating table for Oswego River at Battle Island, N. Y., for 1906.

\begin{tabular}{|c|r|r|r|r|r|r|r|}
\hline $\begin{array}{c}\text { Gage } \\
\text { height. }\end{array}$ & $\begin{array}{c}\text { Dis- } \\
\text { eharge. }\end{array}$ & $\begin{array}{c}\text { Gage } \\
\text { height. }\end{array}$ & $\begin{array}{c}\text { Dis- } \\
\text { charge. }\end{array}$ & $\begin{array}{c}\text { Gage } \\
\text { height. }\end{array}$ & $\begin{array}{c}\text { Dis- } \\
\text { charge. }\end{array}$ & $\begin{array}{c}\text { Gage } \\
\text { height. }\end{array}$ & $\begin{array}{c}\text { Dis- } \\
\text { charge. }\end{array}$ \\
\cline { 1 - 3 } Feet. & Sec.-ft. & Feet. & Sec.-ft. & Fect. & Sec.-ft. & Feet. & Sec.-ft. \\
5.00 & 7,300 & 5.70 & 8,690 & 6.40 & 10,120 & 7.20 & 11,820 \\
5.10 & 7,490 & 5.80 & 8,890 & 6.50 & 10,330 & 7.40 & 12,260 \\
5.20 & 7,690 & 5.90 & 9.090 & 6.60 & $10,5 \leq 0$ & 7.60 & 12,700 \\
5.30 & 7,890 & 6.00 & 9,300 & 6.70 & 10,750 & 7.80 & 13,130 \\
5.40 & 8,090 & 6.10 & 9,500 & 6.80 & 10,950 & 8.00 & 13,580 \\
5.50 & 8,290 & 6.20 & 9,710 & 6.90 & 11,170 & 8.20 & 14,020 \\
5.60 & 8,490 & 6.30 & 9,920 & 7.00 & 11,390 & 8.40 & 14,470 \\
\hline
\end{tabular}

Note.-The abore table is applicable only for open-channel conditions. It is based on discharge measurements made during 1900-1904, and is fairly well defined.

Monthly discharge of Oswego River at Battle Island, N. Y., for 1906.

[Drainage area, 4,990 square miles.]

\begin{tabular}{|c|c|c|c|c|c|}
\hline \multirow[b]{2}{*}{ Month. } & \multicolumn{3}{|c|}{ Discharge in second-feet. } & \multicolumn{2}{|c|}{ Run-.off } \\
\hline & Maximum. & Minimum. & Mean. & $\begin{array}{l}\text { Sec.-ft.per } \\
\text { sq. mile }\end{array}$ & $\begin{array}{l}\text { Depth in } \\
\text { inches. }\end{array}$ \\
\hline $\begin{array}{l}\text { January.......... } \\
\text { March } a . . . \\
\text { A pril ............. }\end{array}$ & $\begin{array}{l}11,300 \\
12,000 \\
14,500\end{array}$ & $\begin{array}{l}7,790 \\
7,200 \\
9,610\end{array}$ & $\begin{array}{r}9,610 \\
8,670 \\
12,400\end{array}$ & $\begin{array}{l}\text { 1. } 93 \\
\text { 1. } 74 \\
\text { 2. } 48\end{array}$ & $\begin{array}{l}\text { 2. } 22 \\
\text { 1. } 55 \\
2.77\end{array}$ \\
\hline
\end{tabular}

a March 1-19, 27-31; discharge for Mareh 18 estimated.

Note.-Values for 1906 are excellent.

CANANDAIgUA OUTLET AT ALLOWAY, N. Y.

A temporary gage was erected by F. P. Williams, at the highway bridge across the Canandaigua Outlet at Alloway September 18, 1906. The gage consists of a board divided to feet and tenths, secured vertically to the northwest wing wall of the bridge. The zero mark is at 
elevation 408.0 and is referred to a bench mark consisting of a chisel draft on the northwest abutment of the bridge having an approximate elevation of 420.25 feet. The gage was read each day from September 18 to October 30, 1906, inclusive, by George Tuscher; observations were taken at $7 \mathrm{a} . \mathrm{m}$., at noon, and at $6 \mathrm{p}$. m. The mean daily elevation has been obtained by adding together twice the morning reading, plus the noon reading, plus twice the afternoon reading, and dividing the sum by 5 . Measurements by means of surface floats were made at a point about 500 feet below the bridge. Current-meter measurements are made on the downstream side of the Alloway Bridge. Owing to regulation by storage in Canandaigua Lake, the flow in the outlet ordinarily fluctuates but little during the day. There are, however, a number of dams in the outlet by which the flow may be temporarily held back as pondage.

Daily gage height, in feet, of Canandargua Outlet at Alloway, N. Y., for 1906.

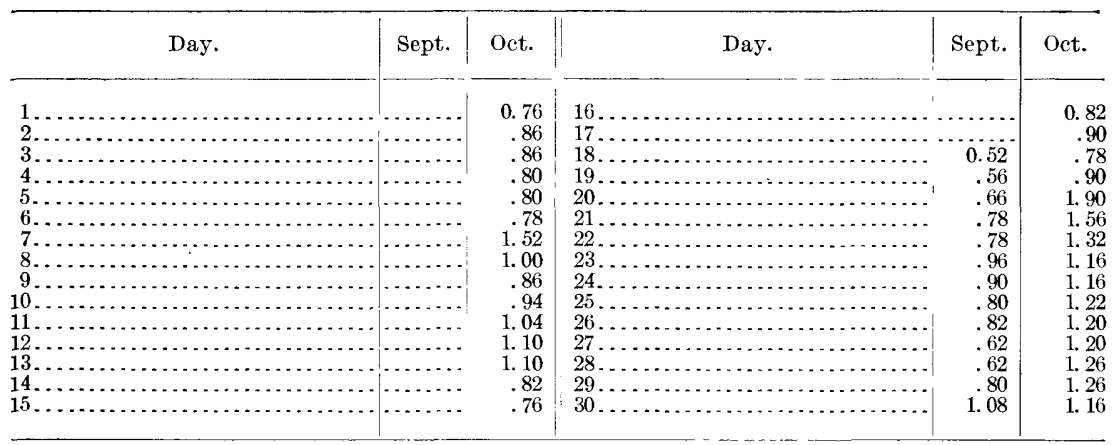

SENECA LAKE AT GENEVA, N. Y.

A gaging station was established at the foot of Seneca Lake, October 18, 1905. The record is furnished by the department of public works, Geneva, N. Y., C. T. Church, superintendent. Readings are taken Wednesday night of each week by the engineer, Reynolds Hill, after the pumps are stopped.

The station is at the pump house of the city water supply, about 2 miles south of Geneva, along the west shore of the lake. Two 5-foot sections of galvanized iron gage, divided into feet and tenths, are fastened to a center post in the intake well; elevation of zero referred to United States Geological Survey tablet at Geneva, 440.78 .

Keuka Lake:

Drainage areas tributary to Seneca Lake.

Above outlet

Square miles.

Water surface

Between Keuka Outlet and Senera Lake.......................... 24.80

Total 
Catherine Creek:

Square miles.

Above Montaur Falls.

66.5

Montaur Falls to Seneca Lake.

29.9

Total

96.4

Glen Creek

23.5

All other drainage.

317.8

Total.

641

Water surface of Seneca Lake. 67.2

Grand total

708. 2

Gage heights of Seneca Lake at Geneva, N. Y., 1905-6.

1905.

October 25

October 31 .

November 8 .

November 15

November 22.

November 29

December 6 .

December 13 .

December 21 .

December 30 1906.

January 3 .

January 10.

January 17

January 24

January 31

February 7

February 14

February 21

February 28

March 7 .

March 14.

March 21

March 28

April 4

April 11

April 18

April 25

May 2.

May 9 .

May 16

May 23

\begin{tabular}{r|} 
Feet. \\
5.0 \\
4.8 \\
4.6 \\
5.0 \\
4.3 \\
4.3 \\
4.5 \\
4.4 \\
4.5 \\
4.7
\end{tabular}

4. 7

4. 8

4. 6

4.7

4. 7

4. 5

4. 4

4. 4

4. 3

4. 4

4. 4

3. 9

4.3

4. 7

4. 9

. 5.1

. 5.3

5. 1

. 5.1

‥ 5.1 5. 1
1906.

Feet. May $30 \ldots \ldots \ldots \ldots \ldots \ldots \ldots \ldots \ldots . . .5 .2$

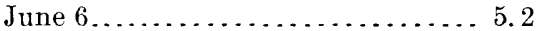

June $13 \ldots \ldots \ldots \ldots \ldots \ldots \ldots \ldots \ldots \ldots . .5 .2$

June $20 \ldots \ldots \ldots \ldots \ldots \ldots \ldots \ldots . \ldots .5 .6$

June $27 \ldots \ldots \ldots \ldots \ldots \ldots \ldots \ldots . \ldots . \ldots$

July $4 \ldots \ldots \ldots \ldots \ldots \ldots \ldots \ldots \ldots \ldots .5 .4$

July $11 \ldots \ldots \ldots \ldots \ldots \ldots \ldots \ldots \ldots$

July $18 \ldots \ldots \ldots \ldots \ldots \ldots \ldots \ldots \ldots .5 .4$

July $26 \ldots \ldots \ldots \ldots \ldots \ldots \ldots \ldots \ldots . \ldots .5 .4$

August 1.................. 5.3

August $8 . \ldots \ldots \ldots \ldots \ldots \ldots \ldots \ldots(a)$

August $15 \ldots \ldots \ldots \ldots \ldots \ldots \ldots \ldots(a)$

August $22 \ldots \ldots \ldots \ldots \ldots \ldots \ldots \ldots,(a)$

Augist $29 \ldots \ldots \ldots \ldots \ldots \ldots \ldots \ldots . \ldots \ldots$

September $5 \ldots \ldots \ldots \ldots \ldots \ldots \ldots . .5 .4$

September $12 \ldots \ldots \ldots \ldots \ldots \ldots \ldots . .2$

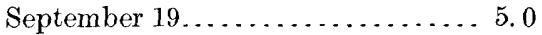

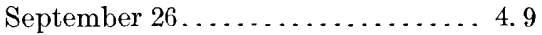

October $3 \ldots \ldots \ldots \ldots \ldots \ldots \ldots \ldots . .4 .8$

October $10 \ldots \ldots \ldots \ldots \ldots \ldots \ldots \ldots .4 .8$

October $17 \ldots \ldots \ldots \ldots \ldots \ldots \ldots \ldots .4 .7$

October $24 \ldots \ldots \ldots \ldots \ldots \ldots \ldots \ldots .4 .8$

October $30 \ldots \ldots \ldots \ldots \ldots \ldots \ldots \ldots . \ldots .5$

November $7 \ldots \ldots \ldots \ldots \ldots \ldots \ldots \ldots . .4 .4$

November $14 \ldots . . . . . . . . . . . . . .4 .4 .4$

November $21 \ldots \ldots \ldots \ldots \ldots \ldots . . .64 .6$

November $28 \ldots \ldots \ldots \ldots \ldots . . . \ldots .4 .5$

December $5 \ldots \ldots \ldots \ldots \ldots \ldots . . . .4 .3$

December $12 \ldots \ldots \ldots \ldots \ldots \ldots \ldots \ldots .4 .4$

December $19 . \ldots \ldots \ldots \ldots \ldots \ldots \ldots . .4 .5$

December $26 \ldots \ldots \ldots \ldots \ldots \ldots \ldots . \ldots$ 
CAYUGA LAKE AT ITHACA, N. Y.

A gaging station was established at the head of Cayuga Lake August 6, 1905. A staff gage is used, attached to the wall of the breakwater about 150 feet from the light-house. Gage readings are taken once each day during the open season and once a week during the winter by Fred Thomas.

Gage height of Cayuga Lake at Ithaca, N. Y., for 1906.

\begin{tabular}{|c|c|c|}
\hline January $6 .$. & $\begin{array}{l}\text { Feet. } \\
1.35\end{array}$ & $\begin{array}{c} \\
\end{array} \quad \begin{array}{c}\text { Feet. } \\
\end{array}$ \\
\hline anuary 13. & 1.25 & July 14. \\
\hline ry 20. & .85 & July 21 \\
\hline & 1. 10 & August 4. \\
\hline & .65 & 2.35 \\
\hline 10. & .55 & 2.2 \\
\hline 17. & .40 & -2.1 \\
\hline$\ldots \ldots$ & .35 & 2.15 \\
\hline . & .50 & $\ldots \ldots 2.0$ \\
\hline & .70 & 1.95 \\
\hline & .65 & 1.9 \\
\hline 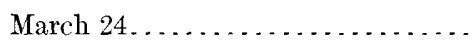 & .35 & 1.85 \\
\hline & 1. 60 & 1.85 \\
\hline & 1.85 & -1.7 \\
\hline & 2.30 & 1. 4 \\
\hline & 2.15 & 1.65 \\
\hline & 1.65 & 1.7 \\
\hline & 1.65 & -1.75 \\
\hline & 1. 70 & 1.3 \\
\hline & 1. 50 & -1.25 \\
\hline & 1. 35 & .95 \\
\hline & 1. 10 & 1.35 \\
\hline & 1. 40 & 1.2 \\
\hline & 1. 35 & $\ldots \ldots \ldots \ldots$ \\
\hline & 1.50 & ber $8 \ldots$. \\
\hline & 1.75 & December $15 \ldots$ \\
\hline .. & 1.90 & December $29 \ldots \ldots \ldots \ldots \ldots$ \\
\hline ब1у 1 . & 2.1 & \\
\hline
\end{tabular}

SENECA RIVER AT BALDWINSVILLE, N. Y.

This station was established Norember 12, 1898. It is located at the State dam in Baldwinsville, 12 miles along the river from the junction of Seneca and Oneida rivers. The conditions at this station and the bench marks are described in Water-Supply Paper No. 170, page 76 , where are given also references to publications that contain data for previous years. 


\section{ONEIDA RIVER NEAR EUCLID, N. Y.}

This station was established August 30, 1902. It is located 7 miles upstream from Three River Point. The conditions at this station and the bench marks are described in Water-Supply Paper No. 170, page 80 , where are given also references to publications that contain data for previous years.

Discharge measurements of Oneuda River near Euclid, N. Y., in 1906.

\begin{tabular}{|c|c|c|c|c|c|}
\hline Date. & Ifydrographer. & Width. & $\begin{array}{l}\text { Area of } \\
\text { section. }\end{array}$ & $\begin{array}{c}\text { Gage } \\
\text { height. }\end{array}$ & Discharge. \\
\hline $\begin{array}{l}\text { May } 17 . \ldots . . . \\
\text { August } 10 \ldots \ldots \\
\text { September } 21 \ldots \\
\text { October } 18 \ldots \ldots\end{array}$ & $\begin{array}{l}\text { C. C. Covert. } \\
\text { E. F. Weeks. } \\
\text {... do....... }\end{array}$ & $\begin{array}{l}\text { Feet. } \\
245 \\
240 \\
238 \\
234\end{array}$ & $\begin{array}{r}S q . f t . \\
1,400 \\
1,010 \\
867 \\
860\end{array}$ & $\begin{array}{l}\text { Feet. } \\
3.30 \\
4.71 \\
\text { a.5.30 } \\
\text { a.5.30 }\end{array}$ & $\begin{array}{r}\text { Sec.-ft. } \\
3,490 \\
1,280 \\
705 \\
906\end{array}$ \\
\hline
\end{tabular}

$a$ Gage heights uncertain.

Daily discharge, in second-feet, of Oneida River near Euclud, N. Y., for 1906.

\begin{tabular}{|c|c|c|c|c|c|c|c|c|c|c|c|c|}
\hline Day. & Jan. & Feb. & Mar. & Apr. & May. & June. & July. & Aug. & Sept. & Oet. & Nov. & Dec. \\
\hline $\begin{array}{l}1 . \\
2 . \\
3 . \\
4 . \\
5 .\end{array}$ & $\begin{array}{l}3,720 \\
4,030 \\
4,030 \\
4,130 \\
4,230\end{array}$ & $\begin{array}{l}5,240 \\
5,240 \\
5,130 \\
4,900 \\
4,680\end{array}$ & $\begin{array}{l}3,270 \\
3,100 \\
3,370 \\
3,420 \\
3,570\end{array}$ & $\begin{array}{l}4,900 \\
5,240 \\
5,240 \\
5,350 \\
5,350\end{array}$ & $\begin{array}{l}4,180 \\
4,070 \\
3,920 \\
4,130 \\
4,180\end{array}$ & $\begin{array}{l}2,380 \\
2,380 \\
2,340 \\
2,290 \\
2,250\end{array}$ & $\begin{array}{l}2,070 \\
2,070 \\
2,070 \\
2,210 \\
2,340\end{array}$ & $\begin{array}{r}1,570 \\
1,380 \\
1,350 \\
1,140 \\
907\end{array}$ & $\begin{array}{l}866 \\
783 \\
742 \\
742 \\
742\end{array}$ & $\begin{array}{l}845 \\
783 \\
762 \\
804 \\
824\end{array}$ & $\begin{array}{l}1,090 \\
1,120 \\
1,190 \\
1,090 \\
1,090\end{array}$ & $\begin{array}{l}1,980 \\
1,980 \\
1,870 \\
1,970 \\
2,260\end{array}$ \\
\hline $\begin{array}{l}6 . \\
7 . \\
8 . \\
9 . \\
10 .\end{array}$ & & $\begin{array}{l}4,280 \\
4,180 \\
3,980 \\
3,620 \\
3,620\end{array}$ & $\begin{array}{l}3,720 \\
3,720 \\
3,570 \\
3,470 \\
3,420\end{array}$ & $\begin{array}{l}5,600 \\
5,470 \\
5,470 \\
6,580 \\
6,970\end{array}$ & & $\begin{array}{l}2,110 \\
2,250 \\
2,420 \\
2,590 \\
2,630\end{array}$ & $\begin{array}{l}2,210 \\
2,180 \\
2,180 \\
2,040 \\
2,000\end{array}$ & $\begin{array}{l}907 \\
907 \\
990 \\
990 \\
990\end{array}$ & 742 & $\begin{array}{r}907 \\
845 \\
949 \\
1,070 \\
907\end{array}$ & $\begin{array}{l}1,090 \\
1,090 \\
1,090 \\
1,090 \\
1,090\end{array}$ & $\begin{array}{l}2,370 \\
2,370 \\
2,540 \\
2,580 \\
2,750\end{array}$ \\
\hline & $\begin{array}{l}4,030 \\
4,030 \\
3,830 \\
3,620 \\
3,620\end{array}$ & $\begin{array}{l}3,050 \\
2,880\end{array}$ & $\begin{array}{l}3,420 \\
3,220 \\
3,220 \\
3,220 \\
3,100\end{array}$ & $\begin{array}{l}6,330 \\
6,330 \\
6,520 \\
6,710 \\
6,710\end{array}$ & & $\begin{array}{l}2,630 \\
2,510 \\
2,630 \\
2,630 \\
2,630\end{array}$ & $\begin{array}{l}1,920 \\
1,920 \\
1,780 \\
1,780 \\
1,780\end{array}$ & $\begin{array}{r}907 \\
845 \\
990 \\
1,300 \\
1,240\end{array}$ & & $\begin{array}{l}990 \\
990 \\
990 \\
969 \\
907\end{array}$ & $\begin{array}{l}1,120 \\
1,190 \\
1,170 \\
1,090 \\
1,020\end{array}$ & $\begin{array}{l}2,880 \\
2,880 \\
2,710 \\
2,630 \\
2,630\end{array}$ \\
\hline & $\begin{array}{l}3,620 \\
3,570 \\
3,620 \\
3,520 \\
3,570\end{array}$ & $\begin{array}{l}2,880 \\
2,790 \\
2,710 \\
2,540 \\
2,540\end{array}$ & $\begin{array}{l}2,880 \\
2,880 \\
2,88 \mathrm{~J} \\
2,790 \\
2,710\end{array}$ & $\begin{array}{l}6,710 \\
6,970 \\
6,840 \\
6,840 \\
6,580\end{array}$ & & & $\begin{array}{l}1,740 \\
1,640 \\
1,640 \\
1,600 \\
1,500\end{array}$ & $\begin{array}{l}1,170 \\
1,090 \\
1,090 \\
1,140 \\
1,300\end{array}$ & $\begin{array}{l}493 \\
679\end{array}$ & $\begin{array}{r}928 \\
1,020 \\
1,090 \\
1,120 \\
1,140\end{array}$ & $\begin{array}{l}1,120 \\
1,190 \\
1,270 \\
1,300 \\
1,330\end{array}$ & $\begin{array}{l}2,670 \\
2,710 \\
2,710 \\
2,710 \\
2,830\end{array}$ \\
\hline & $\begin{array}{l}3,880 \\
4,230 \\
4,740 \\
4,840 \\
5,180\end{array}$ & $\begin{array}{l}2,580 \\
2,540 \\
2,790 \\
2,880 \\
3,000\end{array}$ & $\begin{array}{l}2,630 \\
2,630 \\
2,540 \\
2,370 \\
2,370\end{array}$ & $\begin{array}{l}6,330 \\
6,210 \\
6,025 \\
5,840\end{array}$ & $\begin{array}{l}2,630 \\
2,590\end{array}$ & & $\begin{array}{l}1,500 \\
1,500 \\
1,500 \\
1,450 \\
1,400\end{array}$ & $\begin{array}{r}1,270 \\
1,190 \\
1,090 \\
1,070 \\
990\end{array}$ & $\begin{array}{l}762 \\
824 \\
824\end{array}$ & $\begin{array}{l}990 \\
969 \\
949 \\
949 \\
949\end{array}$ & $\begin{array}{l}1,500 \\
1,570 \\
1,300 \\
1,300 \\
1,450\end{array}$ & $\begin{array}{l}2,880 \\
2,880 \\
2,880 \\
3,050 \\
2,960\end{array}$ \\
\hline 8. & $\begin{array}{l}5,320 \\
5,240 \\
5,240 \\
5,130 \\
4,900\end{array}$ & $\begin{array}{l}3,140 \\
2,920 \\
3,100\end{array}$ & $\begin{array}{l}2,790 \\
3,570 \\
3,930 \\
4,450 \\
4,790\end{array}$ & $\begin{array}{l}5,295 \\
5,130 \\
4,955 \\
4,680\end{array}$ & $\begin{array}{l}2,680 \\
2,760 \\
2,590 \\
2,470\end{array}$ & $\begin{array}{l}2,070 \\
2,070 \\
2,070 \\
2,070 \\
2,070\end{array}$ & $\begin{array}{l}1,300 \\
1,300 \\
1,400 \\
1,710 \\
1,920\end{array}$ & $\begin{array}{l}990 \\
949 \\
907 \\
949 \\
907 \\
866\end{array}$ & $\begin{array}{l}824 \\
824 \\
824 \\
824 \\
886\end{array}$ & $\begin{array}{r}949 \\
949 \\
1,020 \\
1,090 \\
1,090 \\
1,090\end{array}$ & $\begin{array}{l}1,640 \\
1,640 \\
1,680 \\
1,780 \\
1,780\end{array}$ & $\begin{array}{l}2,670 \\
2,500 \\
2,370 \\
2,230 \\
2,580 \\
2,710\end{array}$ \\
\hline
\end{tabular}

NoTE.-During January, February, and a part of March the river was partly frozen above dam, but not enough to modify fiow. 
Monthly discharge of Oneida Rrier near Euclid, N. Y., for 1906.

[Drainage area, 1,310 square miles.]

\begin{tabular}{|c|c|c|c|c|c|}
\hline \multirow[b]{2}{*}{ Month. } & \multicolumn{3}{|c|}{ Discharge in second-feet. } & \multicolumn{2}{|c|}{ Run-off. } \\
\hline & Maximum. & Minimum. & Mean. & $\begin{array}{l}\text { Sec.-ft.per } \\
\text { sq. mile. }\end{array}$ & $\begin{array}{l}\text { Depth in } \\
\text { inches. }\end{array}$ \\
\hline January . . & 5,350 & 3,570 & 4,240 & 3.24 & 3.74 \\
\hline February... & 5,240 & 2,540 & 3,470 & 2.65 & 2.76 \\
\hline March.... & 4,790 & 2,370 & 3,200 & 2.44 & 2.81 \\
\hline April.. & 6,970 & 4,680 & 5,970 & 4. 56 & 5.09 \\
\hline May. & 4,240 & 2,470 & 3,350 & 2.56 & 2.95 \\
\hline June. & 2,800 & 2,070 & 2,390 & 1.83 & 2.04 \\
\hline July. . & 2,340 & 1,300 & 1,780 & 1.36 & 1.57 \\
\hline August.... & 1,570 & 866 & 1,080 & .824 & .950 \\
\hline September... & 886 & 495 & 744 & .568 & .634 \\
\hline October......... & 1,140 & 762 & 962 & .734 & .846 \\
\hline November....... & 1,780 & 1,020 & 1,280 & .977 & 1.09 \\
\hline Decemiber......... & 5,050 & 1,870 & 2,570 & 1.96 & 2.26 \\
\hline The year.. & 6,970 & 495 & 2,570 & 1.98 & 26.74 \\
\hline
\end{tabular}

Note.-Above values are good.

ONEIDA CREEK AT KENWOOD, N. Y.

A report of the flow of this stream during the latter portion of the low-water season of 1906 has been furnished by the Oneida Community. The record includes the flow through a 24-inch Hercules wheel and a 24-inch Camden water wheel, as well as the flow over the dam when any occur. The Camden water wheel was little used during this period. The water was drawn below crest level of Sunset Lake storage pond and nearly the entire twenty-four hour flow of the stream passed through the wheels during the ten and one-fourth hours daily run. No adequate records were kept during the first three weeks of September. The run of the mill, however, indicates that the flow was considerably less than during the period covered by the record. A gaging record of this stream in 1900 showed a minimum flow for several days of 13 to 15 second-feet, or an average of 0.222 second-foot per square mile from a tributary drainage area of 63 square miles.

Discharge of Oneida Creek at Kenwood, N. Y., for 1906.

Second-feet.

September $2 \cdot 2$

September $24 \ldots \ldots \ldots \ldots \ldots \ldots . . .19 .0$

September 25 .

September 26 .

September 27

September 28 .

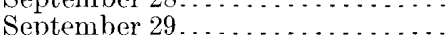

October 1

October 2

October 3

October 5

October 6

October 7

October 8

October 9
Second-feet.

October $10 \ldots \ldots \ldots \ldots \ldots \ldots \ldots . . \ldots .6$

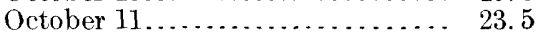

October $12 \ldots \ldots \ldots \ldots \ldots \ldots \ldots \ldots . \ldots \ldots . \ldots .23 .2$

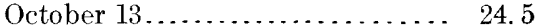

October $14 \ldots \ldots \ldots \ldots \ldots \ldots \ldots . \ldots 19.2$

October $15 \ldots \ldots \ldots \ldots \ldots \ldots \ldots . . \ldots \ldots$

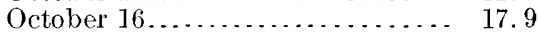

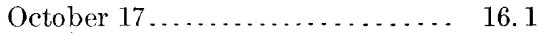

October $18 \ldots \ldots \ldots \ldots \ldots \ldots \ldots \ldots . \ldots \ldots .1$

October $19 \ldots \ldots \ldots \ldots \ldots \ldots \ldots \ldots . . \ldots \ldots$

October $20 \ldots \ldots \ldots \ldots \ldots \ldots \ldots \ldots$

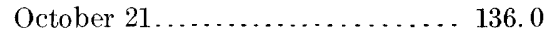

October $22 \ldots \ldots \ldots \ldots \ldots \ldots \ldots \ldots .61 .7$

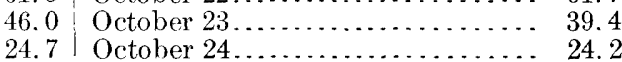


Rating table for Chittenango Creek at Chittenango, N. Y., for 1906.

\begin{tabular}{|c|r|r|r||r|r|r|r|}
\hline $\begin{array}{c}\text { Gage } \\
\text { height. }\end{array}$ & $\begin{array}{c}\text { Dis- } \\
\text { charge. }\end{array}$ & $\begin{array}{c}\text { Gage } \\
\text { height. }\end{array}$ & $\begin{array}{c}\text { Dis- } \\
\text { charge. }\end{array}$ & $\begin{array}{c}\text { Gage } \\
\text { height. }\end{array}$ & $\begin{array}{c}\text { Dis- } \\
\text { charge. }\end{array}$ & $\begin{array}{c}\text { Gage } \\
\text { height. }\end{array}$ & $\begin{array}{c}\text { Dis- } \\
\text { charge. }\end{array}$ \\
\cline { 1 - 2 } Feet. & Sec.-ft. & Feet. & Sec.-ft. & Feet. & Sec.-ft. & Feet. & Sec.-ft. \\
0.80 & 20 & 1.60 & 85 & 2.40 & 275 & 3.20 & 630 \\
0.90 & 25 & 1.70 & 100 & 2.50 & 315 & 3.30 & 680 \\
1.00 & 30 & 1.80 & 115 & 2.60 & 355 & 3.40 & 735 \\
1.10 & 35 & 1.90 & 135 & 2.70 & 395 & 3.50 & 790 \\
1.20 & 40 & 2.00 & 155 & 2.80 & 440 & 3.60 & 850 \\
1.30 & 50 & 2.10 & 180 & 2.90 & 485 & 3.70 & 910 \\
1.40 & 60 & 2.20 & 210 & 3.00 & 530 & & \\
1.50 & 70 & 2.30 & 240 & 3.10 & 530 & & \\
\hline
\end{tabular}

NOTE.-The above table is applicable only for open-channel conditions. It is based on discharge measurements made during $1904-1906$, and is well defined.

Monthıy discharge of Chuttenango Creek at Chittenango, N. Y., for 1906.

[Drainage area, 79 square miles.]

\begin{tabular}{|c|c|c|c|c|c|}
\hline \multirow[b]{2}{*}{ Month. } & \multicolumn{3}{|c|}{ Discharge in second-feet. } & \multicolumn{2}{|c|}{ Run-off. } \\
\hline & Maximum. & Minimum. & Mean. & $\begin{array}{l}\text { Sec.-ft. per } \\
\text { sq. mile. }\end{array}$ & $\begin{array}{l}\text { Depth in } \\
\text { inches. }\end{array}$ \\
\hline 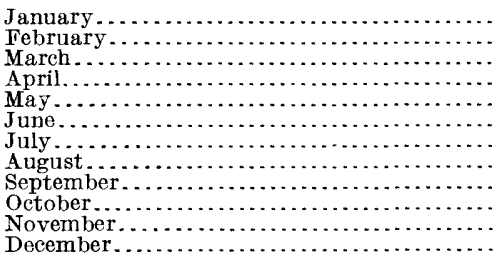 & $\begin{array}{r}395 \\
240 \\
910 \\
508 \\
555 \\
440 \\
210 \\
85 \\
100 \\
155 \\
275 \\
630\end{array}$ & $\begin{array}{r}108 \\
45 \\
55 \\
78 \\
45 \\
45 \\
40 \\
20 \\
30 \\
60 \\
40 \\
30\end{array}$ & $\begin{array}{l}177 \\
87.8 \\
169 \\
217 \\
166 \\
164 \\
68.9 \\
52.6 \\
61.7 \\
91.6 \\
92.7 \\
113\end{array}$ & $\begin{array}{l}2.24 \\
1.11 \\
2.14 \\
2.75 \\
2.10 \\
2.08 \\
.872 \\
.666 \\
.654 \\
1.16 \\
1.17 \\
1.43\end{array}$ & $\begin{array}{r}2.58 \\
1.16 \\
2.47 \\
3.07 \\
2.42 \\
2.32 \\
1.01 \\
.76 \\
.73 \\
1.34 \\
1.30 \\
1.65\end{array}$ \\
\hline The year.... & 910 & 20 & 121 & 1.53 & 20.82 \\
\hline
\end{tabular}

Note.-Values are rated as follows: January, March to July, and October to December, good; February, August, and September, fair.

\section{SALMON RIVER BASIN.}

\section{DESCRIPTION OF BASIN.}

Salmon River rises in the southwestern part of Lewis County, N. Y., flows first southward then northwestward, and enters Lake Ontario near Port Ontario. The basin above the gaging station is rolling and very sandy, rock lying near the surface in the upper part of the watershed, where there are also extensive tracts of original forest. The region is subject to heavy falls of snow, which sometimes accumulates in the forest areas to a depth of several feet and melts gradually during March and April, feeding the stream. 
Daily gage height, in feet, of Salmon River near Pulaski, N. Y., for 1906-Continued.

\begin{tabular}{|c|c|c|c|c|c|c|c|c|c|c|c|c|}
\hline Day. & Jan. & Feb. & Mar. & Apr. & May. & June. & July. & Aug. & Sept. & Oct. & Nov. & Dec. \\
\hline $\begin{array}{l}21 \ldots \\
22 \ldots \\
23 \ldots \\
24 \ldots \\
25 \ldots\end{array}$ & $\begin{array}{l}3.68 \\
4.40 \\
5.75 \\
6.80 \\
5.40\end{array}$ & $\begin{array}{l}3.38 \\
3.95 \\
3.92 \\
3.85 \\
4.05\end{array}$ & $\begin{array}{l}2.98 \\
2.98 \\
2.92 \\
2.98 \\
2.95\end{array}$ & $\begin{array}{l}5.15 \\
510 \\
5.02 \\
4.45 \\
4.20\end{array}$ & $\begin{array}{l}3.12 \\
3.10 \\
3.02 \\
3.00 \\
2.98\end{array}$ & $\begin{array}{l}2.72 \\
2.70 \\
2.78 \\
2.80 \\
2.78\end{array}$ & $\begin{array}{l}2.70 \\
2.72 \\
2.68 \\
265 \\
2.60\end{array}$ & $\begin{array}{l}2.38 \\
2.45 \\
2.45 \\
2.38 \\
2.35\end{array}$ & $\begin{array}{l}2.25 \\
2.32 \\
2.58 \\
2.72 \\
2.48\end{array}$ & $\begin{array}{l}3.95 \\
3.45 \\
3.18 \\
3.02 \\
3.12\end{array}$ & $\begin{array}{l}3.52 \\
3.58 \\
3.52 \\
3.40 \\
3.25\end{array}$ & $\begin{array}{l}3.28 \\
3.18 \\
3.00 \\
2.95 \\
3.02\end{array}$ \\
\hline $\begin{array}{l}26 \ldots \\
27 \ldots \\
28 \ldots \\
29 \ldots \\
30 \ldots \\
31 \ldots \\
\end{array}$ & $\begin{array}{l}4.75 \\
440 \\
4.12 \\
3.68 \\
3.70 \\
3.78\end{array}$ & $\begin{array}{l}\text { 4. } 30 \\
\text { 3. } 80 \\
\text { 3. } 55\end{array}$ & $\begin{array}{l}2.98 \\
4.45 \\
5.28 \\
5.2 \\
4.95 \\
4.78\end{array}$ & $\begin{array}{ll}4 & 02 \\
4 & 02 \\
4 . & 08 \\
4 . & 00 \\
4 & 05 \\
\text { …. }\end{array}$ & $\begin{array}{l}3.00 \\
3.28 \\
3.75 \\
3.30 \\
3.12 \\
3.00\end{array}$ & $\begin{array}{r}2.70 \\
2.62 \\
2.60 \\
2.68 \\
3.30 \\
\text {...... }\end{array}$ & $\begin{array}{l}2.52 \\
2.50 \\
2.50 \\
2.50 \\
2.52 \\
2.65\end{array}$ & $\begin{array}{l}2.35 \\
2.35 \\
2.35 \\
2.35 \\
2.35 \\
2.30\end{array}$ & $\begin{array}{l}\text { 2. } 40 \\
\text { 2. } 40 \\
\text { 2. } 48 \\
\text { 2. } 45 \\
\text { 3. } 32\end{array}$ & $\begin{array}{l}3.42 \\
3.30 \\
3.48 \\
3.75 \\
3.55 \\
3.40\end{array}$ & $\begin{array}{l}3.22 \\
3.92 \\
4.60 \\
4.05 \\
\text { 3. } 50\end{array}$ & $\begin{array}{l}3.18 \\
3.10 \\
3.00 \\
3.00 \\
3.00 \\
3.70\end{array}$ \\
\hline
\end{tabular}

Note.-Stream not entirely closed by ice during winter period, but channel obstructed at times by needle and anchor ice.

Ratıng table for Salmon Ruer near Pulaski, N. Y., for 1906.

\begin{tabular}{|c|c|c|c|c|c|c|c|}
\hline $\begin{array}{c}\text { Gage } \\
\text { height. }\end{array}$ & $\begin{array}{c}\text { D1s- } \\
\text { eharge. }\end{array}$ & $\begin{array}{c}\text { Gage } \\
\text { height. }\end{array}$ & $\begin{array}{l}\text { Dis- } \\
\text { charge. }\end{array}$ & $\begin{array}{c}\text { Gage } \\
\text { height. }\end{array}$ & $\begin{array}{c}\text { Dis- } \\
\text { charge. }\end{array}$ & $\begin{array}{c}\text { Gage } \\
\text { height. }\end{array}$ & $\begin{array}{c}\text { Dis- } \\
\text { charge. }\end{array}$ \\
\hline Feet. & sec.-ft. & Feet. & Sec.-ft. & Feet. & Sec.-ft. & Feet. & Sec.-ft. \\
\hline 2.20 & 46 & 3. 40 & 620 & 4. 60 & 1,980 & 580 & 4,490 \\
\hline $\begin{array}{l}2.30 \\
2.40\end{array}$ & $\begin{array}{l}67 \\
93\end{array}$ & $\begin{array}{l}3.50 \\
3.60\end{array}$ & $\begin{array}{l}697 \\
781\end{array}$ & $\begin{array}{l}470 \\
4.80\end{array}$ & $\begin{array}{r}2,140 \\
2,300\end{array}$ & $\begin{array}{l}590 \\
600\end{array}$ & $\begin{array}{l}4,780 \\
5,100\end{array}$ \\
\hline 2.50 & 124 & 3.70 & 865 & 490 & 2,470 & 6.20 & 5,770 \\
\hline 2.60 & 161 & 3.80 & 965 & 500 & 2.640 & 6.40 & 6.530 \\
\hline 2. 70 & 204 & 3. 90 & 1,060 & 5. 10 & 2,840 & 660 & 7,340 \\
\hline 2. 80 & 253 & 4.00 & 1,170 & 5. 20 & 3,020 & 680 & 8,190 \\
\hline 2.90 & 307 & 4. 10 & 1,300 & 5. 30 & 3. 240 & 7.00 & 9,070 \\
\hline 3. 00 & 364 & 4. 20 & 1,420 & 5. 40 & 3,460 & 7.2 & 10,000 \\
\hline 3.10 & 422 & 4. 30 & 1,550 & 5.50 & 3,700 & 7. 40 & 11,000 \\
\hline 3.20 & 480 & 4. 40 & 1,680 & 5. 60 & 3,950 & 7.60 & 12,060 \\
\hline 3.30 & 550 & 4. 50 & 1,830 & 5.70 & 4,200 & & \\
\hline
\end{tabular}

NoтE.-The above table is applicable only for open-channel conditions. It is based on discharge measurements made during 1902 to 1906 , and is fairly well defined.

Monthly discharge of Salmon Rwer near Pulaskr, N. Y., for 1906.

[Drainage area, 259 square miles.]

\begin{tabular}{|c|c|c|c|c|c|}
\hline \multirow[b]{2}{*}{ Month. } & \multicolumn{3}{|c|}{ Discharge in second-fcet. } & \multicolumn{2}{|c|}{ Run-off. } \\
\hline & Maximum. & Minimum. & Mean. & $\begin{array}{l}\text { Sec-ft. per } \\
\text { sq. mile. }\end{array}$ & $\begin{array}{l}\text { Depth in } \\
\text { inches. }\end{array}$ \\
\hline January.. & & & 1,340 & 5.17 & 5.96 \\
\hline February. & 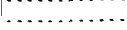 & $\cdots$ & 640 & 2.47 & 2.57 \\
\hline March.... & & & & 3. 40 & 3.92 \\
\hline April.. & 8,620 & 1,180 & 2,350 & 9.07 & 10. 12 \\
\hline May.. & 2,840 & 349 & 943 & 3. 64 & 4.20 \\
\hline June. & 1,620 & 161 & 370 & 1. 43 & 1.60 \\
\hline July.. & 1,750 & 124 & 390 & 1.51 & 1.74 \\
\hline August. & 228 & 67 & 125 & .483 & .56 \\
\hline September. & 567 & 46 & 104 & .402 & .45 \\
\hline October... & 1,360 & 124 & 519 & 2.00 & 2.31 \\
\hline November... & 1,980 & 280 & 606 & 2.34 & 2.61 \\
\hline December........ & 1,830 & 323 & 554 & 2.14 & 2. 47 \\
\hline The year. & 8,620 & 46 & 735 & 2.84 & 38.51 \\
\hline
\end{tabular}

Note.-Values are rated as foliows: January to March, fair, on account of ice obstruction; remainder of 1906 , good. 


\section{BLACK RIVER BASIN.}

\section{DESCRIPTION OF BASIN.}

Black River rises in the western part of Hamilton County, N. Y., flows southwestward across Herkimer County into Oneida County, turns near Forestport and runs somewhat west of north through Lewis County to eastern Jefferson County, and then flows westward to Black River Bay, at the eastern extremity of Lake Ontario. The upper part of the basin is very rugged and mountainous and contains a large number of lakes.

The flow of the river is controlled by storage on its upper tributaries, including Beaver River at Beaver, a series of reservoirs at the headwaters of Moose River, and additional reservoirs at Forestport and on the headwaters of the main river.

Water is diverted from Black River through Forestport feeder to supply the Black River Canal at Boonville. A portion of this diverted water flows northward from Boonville and enters Black River again at Lyons Falls; the remainder flows southward through the Black River Canal and enters the Erie Canal at Rome. The amount of this diversion, which takes place during the season of canal navigation, is not recorded.

\section{BLACK RIVER NEAR FELTS MILLS, N. Y.}

This station was established August 29, 1902. It is located at the dam of the Black River Traction Company, near the village of Felts Mills. The dam is 9 miles upstream from Watertown and 7 miles upstream from the old Huntingtonville gaging station on this stream. The conditions ${ }^{a}$ at this station and the bench marks are described in Water-Supply Paper No. 170, page 87, where are given also references to publications that contain data for previous years.

Daily discharge, in second-feet, of Black River at Felts Mills, N. I., for 1906.

\begin{tabular}{|c|c|c|c|c|c|c|c|c|c|c|c|c|}
\hline Day. & Jan. & Fob. & Mar. & Apr. & May. & June. & July. & Aug. & Sept. & Oct. & Nov. & Dec. \\
\hline $\begin{array}{l}1 . . \\
2 . \\
3 . \\
4 . \\
5 .\end{array}$ & $\begin{array}{l}7,630 \\
7,810 \\
4,640 \\
4,790 \\
5,080\end{array}$ & $\begin{array}{r}5,390 \\
4,490 \\
+3,190 \\
3,080 \\
2,740\end{array}$ & $\begin{array}{l}2,970 \\
2,740 \\
2,440 \\
4,440 \\
5,390\end{array}$ & $\begin{array}{l}7,320 \\
6,720 \\
5,230 \\
4,790 \\
5,080\end{array}$ & $\begin{array}{l}4,790 \\
4,360 \\
4,790 \\
5,550 \\
6,030\end{array}$ & $\begin{array}{l}3,220 \\
1,920 \\
1,920 \\
1,810 \\
1,920\end{array}$ & $\begin{array}{l}3,520 \\
6,170 \\
5,280 \\
5,280 \\
5,990\end{array}$ & $\begin{array}{l}1,530 \\
1,710 \\
1,430 \\
1,450 \\
300\end{array}$ & $\begin{array}{r}880 \\
1,420 \\
1,350 \\
1,440 \\
1,530\end{array}$ & $\begin{array}{l}2,360 \\
2,340 \\
2,010 \\
1,290 \\
1,320\end{array}$ & $\begin{array}{l}2,240 \\
2,020 \\
1,540 \\
1,470 \\
2,400\end{array}$ & $\begin{array}{l}3,070 \\
2,040 \\
2,700 \\
2,000 \\
1,820\end{array}$ \\
\hline $\begin{array}{r}6 \\
7 \ldots \ldots \\
8 \ldots \ldots \ldots \\
9 \ldots \ldots \ldots \\
10 \ldots \ldots\end{array}$ & $\begin{array}{l}6,030 \\
4,600 \\
5,550 \\
5,080 \\
3,690\end{array}$ & $\begin{array}{l}2,540 \\
2,540 \\
2,350 \\
2,350 \\
2,350\end{array}$ & $\begin{array}{l}5,080 \\
4,220 \\
3,560 \\
3,190 \\
2,540\end{array}$ & $\begin{array}{l}5,230 \\
5,080 \\
4,440 \\
5,080 \\
4,490\end{array}$ & $\begin{array}{l}6,540 \\
6,720 \\
5,550 \\
4,940 \\
4,360\end{array}$ & $\begin{array}{l}2,040 \\
2,170 \\
1,920 \\
2,290 \\
2,290\end{array}$ & $\begin{array}{l}2,760 \\
2,810 \\
2,290 \\
2,540 \\
2,420\end{array}$ & $\begin{array}{l}1,620 \\
1,590 \\
1,790 \\
1,680 \\
1,500\end{array}$ & $\begin{array}{r}1,560 \\
1,060 \\
1,260 \\
890 \\
980\end{array}$ & $\begin{array}{l}1,370 \\
1,720 \\
2,380 \\
2,190 \\
2,190\end{array}$ & $\begin{array}{r}\cdot 1,530 \\
1,450 \\
1,440 \\
1,500 \\
1,350\end{array}$ & $\begin{array}{l}1,610 \\
2,200 \\
2,020 \\
1,750 \\
2,260\end{array}$ \\
\hline 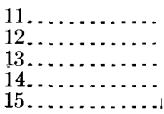 & $\begin{array}{l}3,440 \\
3,310 \\
3,190 \\
2,680 \\
2,630\end{array}$ & $\begin{array}{l}2,950 \\
2,740 \\
2,160 \\
2,160 \\
2,740\end{array}$ & $\begin{array}{l}2,540 \\
3,690 \\
2,540 \\
2,540 \\
2,540\end{array}$ & $\begin{array}{l}4,350 \\
4,790 \\
5,390 \\
5,870 \\
6,930\end{array}$ & $\begin{array}{l}4,360 \\
4,360 \\
3,960 \\
8,010 \\
8,400\end{array}$ & $\begin{array}{l}2,950 \\
3,520 \\
3,220 \\
3,220 \\
2,170\end{array}$ & $\begin{array}{l}2,810 \\
3,0 \times 0 \\
2,540 \\
2,040 \\
1,170\end{array}$ & $\begin{array}{l}1,470 \\
1,080 \\
1,410 \\
1,440 \\
1,830\end{array}$ & $\begin{array}{r}980 \\
700 \\
1,410 \\
1,380 \\
1,240\end{array}$ & $\begin{array}{l}2,600 \\
2,500 \\
2,690 \\
2,120 \\
1,790\end{array}$ & $\left|\begin{array}{l}1,470 \\
2,410 \\
2,320 \\
2,230 \\
2,150\end{array}\right|$ & $\begin{array}{l}1,780 \\
1,860 \\
1,780 \\
2,390 \\
1,890\end{array}$ \\
\hline
\end{tabular}

IRR $206-07-6$ 
Daily discharge, in second-feet, of Black River at Felts Mills, N. Y., for 1906-Cont'd.

\begin{tabular}{|c|c|c|c|c|c|c|c|c|c|c|c|c|}
\hline Day. & Jan. & Feb. & Mar. & $\AA \mathrm{pr}$. & May. & June. & July. & Aug. & Sept. & Oet. & Dec. & Dec. \\
\hline $\begin{array}{l}16 \ldots \\
17 \ldots \\
18 \ldots \\
19 \ldots \\
20 \ldots\end{array}$ & $\begin{array}{l}2,630 \\
2,540 \\
4,490 \\
3,690 \\
3,690\end{array}$ & $\begin{array}{l}2,350 \\
2,160 \\
1,920 \\
2,970 \\
1,990\end{array}$ & $\begin{array}{l}2,350 \\
1,990 \\
1,360 \\
2,440 \\
1,910\end{array}$ & $\begin{array}{r}9,830 \\
13,400 \\
14,200 \\
12,900 \\
11,900\end{array}$ & $\begin{array}{l}9,210 \\
8,790 \\
8,010 \\
6,030 \\
4,870\end{array}$ & $\begin{array}{l}1,920 \\
2,290 \\
3,370 \\
2,950 \\
2,040\end{array}$ & $\begin{array}{l}1,360 \\
1,470 \\
1,470 \\
1,470 \\
1,080\end{array}$ & $\begin{array}{r}1,220 \\
1,110 \\
840 \\
80 \\
1,700\end{array}$ & $\begin{array}{r}890 \\
1,220 \\
1,280 \\
960 \\
1,480\end{array}$ & $\begin{array}{l}1,560 \\
1,470 \\
1,440 \\
1,440 \\
2,380\end{array}$ & $\begin{array}{l}2,030 \\
2,110 \\
2,120 \\
5,230 \\
5,210\end{array}$ & $\begin{array}{l}2,810 \\
3,340 \\
2,890 \\
2,940 \\
2,740\end{array}$ \\
\hline 24. & $\begin{array}{r}3,290 \\
7,710 \\
13,400 \\
18,100 \\
18,800\end{array}$ & $\begin{array}{l}1,990 \\
4,790 \\
4,490 \\
4,490 \\
4,440\end{array}$ & $\begin{array}{l}1,630 \\
2,250 \\
1,750 \\
2,070 \\
1,360\end{array}$ & $\begin{array}{l}11,600 \\
11,300 \\
11,600 \\
10,500 \\
10,000\end{array}$ & $\begin{array}{l}3,220 \\
3,220 \\
3,220 \\
2,680 \\
2,540\end{array}$ & $\begin{array}{l}1,920 \\
1,990 \\
1,700 \\
1,700 \\
1,920\end{array}$ & $\begin{array}{l}1,080 \\
1,080 \\
1,850 \\
1,380 \\
1,840\end{array}$ & $\begin{array}{l}1,300 \\
1,440 \\
1,680 \\
1,910 \\
1,540\end{array}$ & $\begin{array}{r}1,180 \\
970 \\
590 \\
1,700 \\
1,660\end{array}$ & $\begin{array}{l}3,570 \\
3,640 \\
3,120 \\
2,560 \\
2,180\end{array}$ & $\begin{array}{l}4,730 \\
4,590 \\
4,140 \\
3,580 \\
3,160\end{array}$ & $\begin{array}{l}2,480 \\
2,270 \\
1,700 \\
1,280 \\
1,080\end{array}$ \\
\hline $\begin{array}{l}26 . \\
27 . \\
28 . \\
29 . \\
30 .\end{array}$ & $\begin{array}{r}19,000 \\
19,000 \\
11,600 \\
9,000 \\
6,200 \\
6,030\end{array}$ & $\begin{array}{l}5,710 \\
4,490 \\
4,490\end{array}$ & $\begin{array}{l}2,250 \\
2,630 \\
6,370 \\
7,630 \\
7,260 \\
7,440\end{array}$ & $\begin{array}{l}8,590 \\
7,260 \\
6,370 \\
5,450 \\
5,710\end{array}$ & $\begin{array}{l}2,420 \\
3,220 \\
4,120 \\
5,100 \\
5,100 \\
3,960\end{array}$ & $\begin{array}{r}1,810 \\
1,470 \\
1,410 \\
1,430 \\
723\end{array}$ & $\begin{array}{r}1,230 \\
1,070 \\
870 \\
800 \\
1,650 \\
1,330\end{array}$ & $\begin{array}{l}1,310 \\
1,840 \\
1,300 \\
1,280 \\
1,350 \\
1,390\end{array}$ & $\begin{array}{r}1,550 \\
1,180 \\
1,040 \\
860 \\
1,150\end{array}$ & $\begin{array}{l}2,280 \\
2,370 \\
2,420 \\
3,740 \\
2,940 \\
2,670\end{array}$ & $\begin{array}{l}3,130 \\
2,990 \\
5,030 \\
4,500 \\
3,750\end{array}$ & $\begin{array}{l}1,970 \\
1,710 \\
1,650 \\
1,620 \\
1,470 \\
2,390\end{array}$ \\
\hline
\end{tabular}

Note. - The Harmon Paper Company began operations January 2, using a part of the fiow; and no records were kept of run of wheels or tailrace gage until after May 1; hence the discharges for this period are eonsiderably in error. On October 26 and 27 and November 17 and 18 , the crest of dam was obstructed by logs. The following ice conditions prevailed during December, 1906: December 1 to 3 , anchor ice in wheel racks, river partly frozen over; December 7, pond frozen over, ice within 75 feet of crest of dam; December 8, ice up to crest; December 21, ice frozen on crest and holding water back; December 31, ice gone from erest.

Monthly discharge of Black River at Felts Mills, N. Y., for 1906.

[Drainage area, 1,850 square miles.]

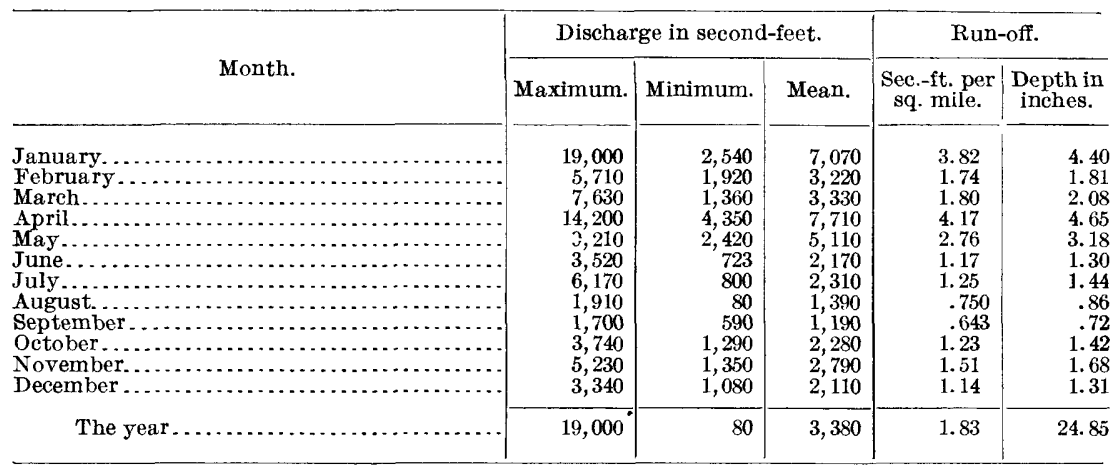

Note.- Values May to December are rated as good; prior to May the probable error is greater than 10 per cent.

\section{MOOSE RIVER AT MOOSE RIVER, N. Y.}

This station was established June 5, 1900. It is located at Moose River village. The conditions at this station and the bench marks are described in Water-Supply Paper No. 170, page 89, where are given also references to publications that contain data for previous years.

Discharge measurements of Moose River at Moose River, N. Y., in 1906.

\begin{tabular}{|c|c|c|c|c|c|}
\hline Date. & Hydrographer. & Width. & $\begin{array}{l}\text { Area of } \\
\text { section. }\end{array}$ & $\begin{array}{c}\text { Gage } \\
\text { height. }\end{array}$ & Discharge. \\
\hline $\begin{array}{l}\text { April } 7 \ldots \ldots \ldots \\
\text { September } 22 . . \\
\text { September } 23 . \\
\text { September } 24 .\end{array}$ & 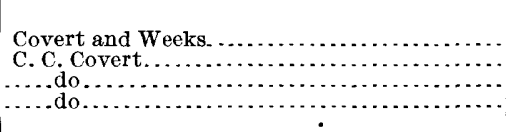 & \begin{tabular}{r|} 
Feet. \\
217 \\
212 \\
215 \\
213
\end{tabular} & $\begin{array}{r}S q \cdot f t . \\
730 \\
440 \\
630 \\
596\end{array}$ & $\begin{array}{r}\text { Feet. } \\
2.52 \\
.97 \\
1.72 \\
1.68\end{array}$ & $\begin{array}{r}\text { Sec.-ft. } \\
791 \\
238 \\
582 \\
545\end{array}$ \\
\hline
\end{tabular}


Daily gage height, in feet, of Moose River at Moose River, N. Y., for 1906.

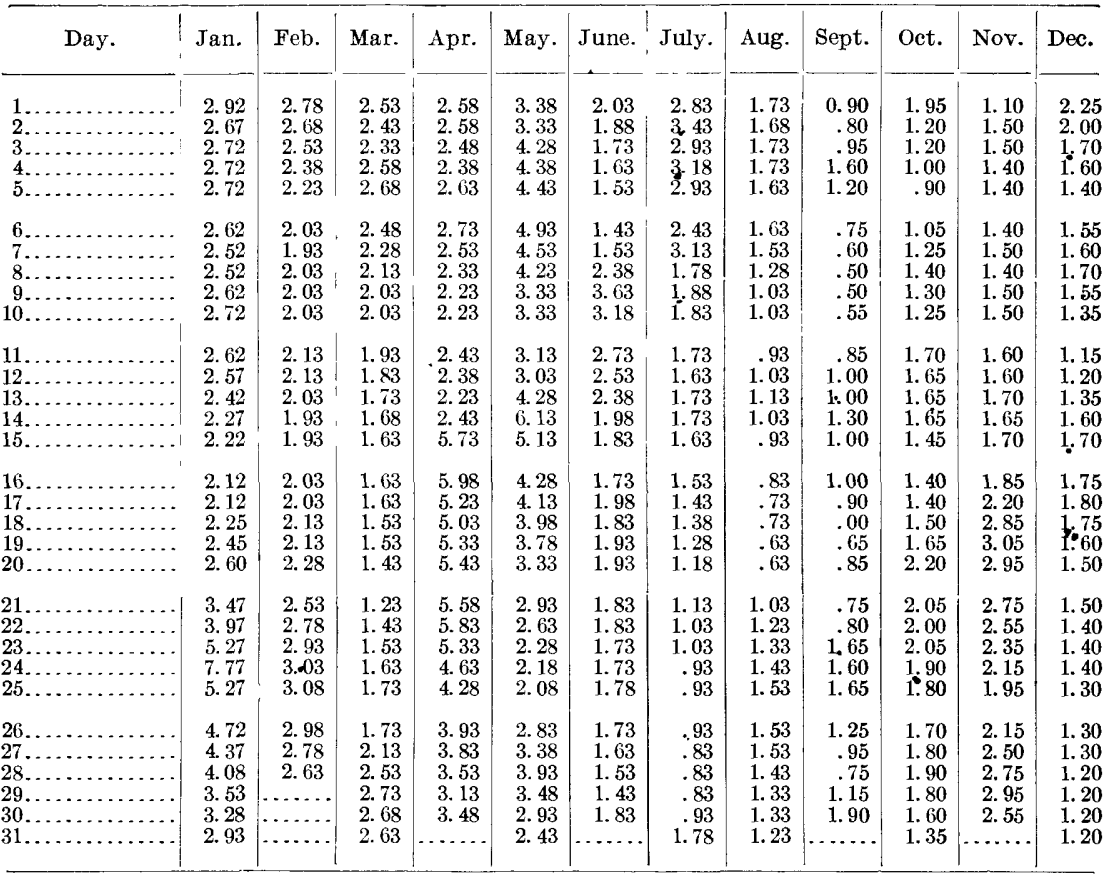

NoTE.-The river was not entirely closed by ice during 1906 . There was considerable shore ice during the latter part of February and through March, ice going out the 4th of April. At times needle ice forms on the rifts below the gage and causes backwater. During the frozen period, gage heights were taken to water surface through a hole in the ice.

Rating table for Moose River at Moose River, N. Y., for 1906.

\begin{tabular}{|c|r|r|r|r|r||r|r|}
\hline $\begin{array}{c}\text { Gage } \\
\text { height. }\end{array}$ & $\begin{array}{c}\text { Dis- } \\
\text { charge. }\end{array}$ & $\begin{array}{c}\text { Gage } \\
\text { height. }\end{array}$ & $\begin{array}{c}\text { Dis- } \\
\text { charge. }\end{array}$ & $\begin{array}{c}\text { Gage } \\
\text { height. }\end{array}$ & $\begin{array}{c}\text { Dis- } \\
\text { charge. }\end{array}$ & $\begin{array}{c}\text { Gage } \\
\text { height. }\end{array}$ & $\begin{array}{c}\text { Dis- } \\
\text { charge. }\end{array}$ \\
\cline { 1 - 2 } Feet. & Sec.-ft. & Feet. & Sec.-ft. & Feet. & Sec.-ft. & Feet. & sec.-ft. \\
0.00 & 103 & 1.40 & 354 & 2.80 & 914 & 5.40 & 3,180 \\
0.10 & 115 & 1.50 & 382 & 2.90 & 968 & 5.60 & 3,440 \\
0.20 & 127 & 1.60 & 412 & 3.00 & 1,023 & 5.80 & 3,700 \\
0.30 & 140 & 1.70 & 444 & 3.20 & 1,139 & 6.00 & 3,980 \\
0.40 & 154 & 1.80 & 477 & 3.40 & 1,264 & 6.20 & 4,260 \\
0.50 & 170 & 1.90 & 511 & 3.60 & 1,399 & 6.40 & 4,555 \\
0.60 & 187 & 2.00 & 547 & 3.80 & 1,545 & 6.60 & 4,855 \\
0.70 & 205 & 2.10 & 585 & 4.00 & 1,700 & 6.80 & 5,160 \\
0.80 & 223 & 2.20 & 626 & 4.20 & 1,870 & 7.00 & 5,480 \\
0.90 & 242 & 2.30 & 669 & 4.40 & 2,060 & 7.20 & 5,800 \\
1.00 & 262 & 2.40 & 715 & 4.60 & 2,260 & 7.40 & 6,130 \\
1.10 & 282 & 2.50 & 763 & 4.80 & 2,480 & 7.60 & 6,470 \\
1.20 & 304 & 2.60 & 812 & 5.00 & 2,700 & 7.80 & 6,810 \\
1.30 & 328 & 2.70 & 862 & 5.20 & 2,940 & & \\
\hline
\end{tabular}

NotE.-The above table is applicable only for open-channel conditions. It is based on discharge measurements made during 1903-1906, and is well defined between gage heights 1.0 foot and 5.0 feet. Measurements above gage height 6.0 feet are impossible at this station, owing to the flashy character of the stream and to large quantities of ice and logs running during high stages. Hence discharges of over 4,000 second-feet are liable to error. 
Monthly discharge of Moose River at Moose River, N. Y., for 1906.

[Drainage area, 346 square miles.]

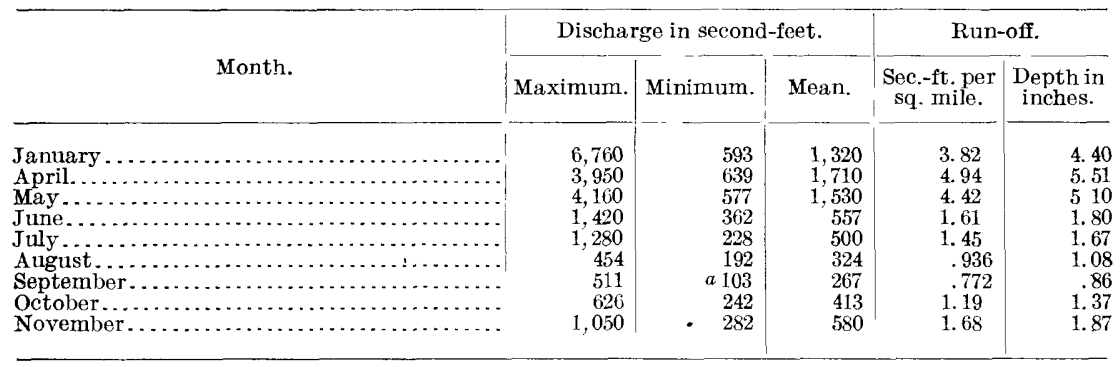

$a$ The low minimum for September was caused by the storage of water by the dam at McKeever.

Note.-Values are rated as follows: January to May and September, good; June to August, October, and November, excellent.

\section{ST. LAWRENCE RIVER DRAINAGE.}

\section{GENERAL FEATURES.}

St. Lawrence River receives the flow of a number of New York streams having their sources in a northerly slope of the Adirondacks and fed by the innumerable lakes with which the region is dotted. Some of these rivers, as the Grass, Raquette, and St. Regis, lie entirely within the United States; others, notably Salmon, Trout, Chateaugay, and English rivers, cross the international boundary and flow northward into the St. Lawrence in Canada, as does also Richelieu River, the outlet of Lake Champlain. The following table gives a list of the principal tributaries of the St. Lawrence in the United States, with the areas drained by them:

\section{Drainage areas of St. Laurence River tributaries in the United States.}

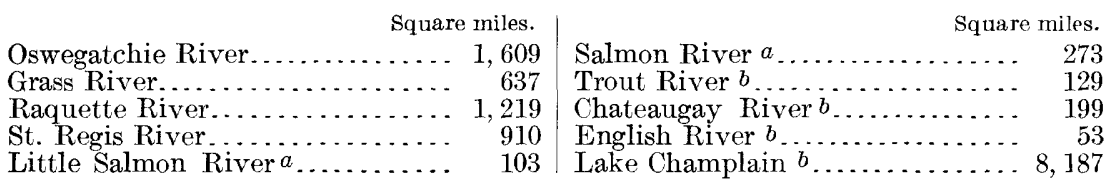

The St. Lawrence drains, through Lake Champlain, an area of 4,56 ] square miles in the State of Vermont. This drainage is practically all from Missisquoi, Lamoille, and Winooski rivers and Otter Creek.

\section{OSWEGATCHIE RIVER BASIN.}

\section{DESCRIPTION OF BASIN.}

Oswegatchie River has its source in the region of lakes and timbered swamps in the southern part of St. Lawrence County, N. Y. 
The largest of the lakes is Cranberry Lake, which affords valuable storage to water-power users on its outlet, East Branch of Oswegatchie River. East and West branches flow in a general northwesterly direction and unite near Talcville. From Gouverneur to Oxbow the river flows southwestward; it then turns sharply and flows northeastward to Rensselaer Falls, turns again to the northwest, receives the outlet of Black Lake at Galilee, and finally enters the St. Lawrence at Ogdensburg

OSWEGATCHIE RIVER NEAR OGDENSBURG, N. Y.

This station was established May 16, 1903. It is located at Eel Weir Bridge, just below the junction of Oswegatchie River and Black Lake outlet. The conditions at this station and the bench marks are described in Water-Supply Paper No. 170, page 93, where are given also references to publications that contain data for previous years.

Discharge measurements of Oswegatchie River near Ogdensburg, N. Y., in 1903-1906.

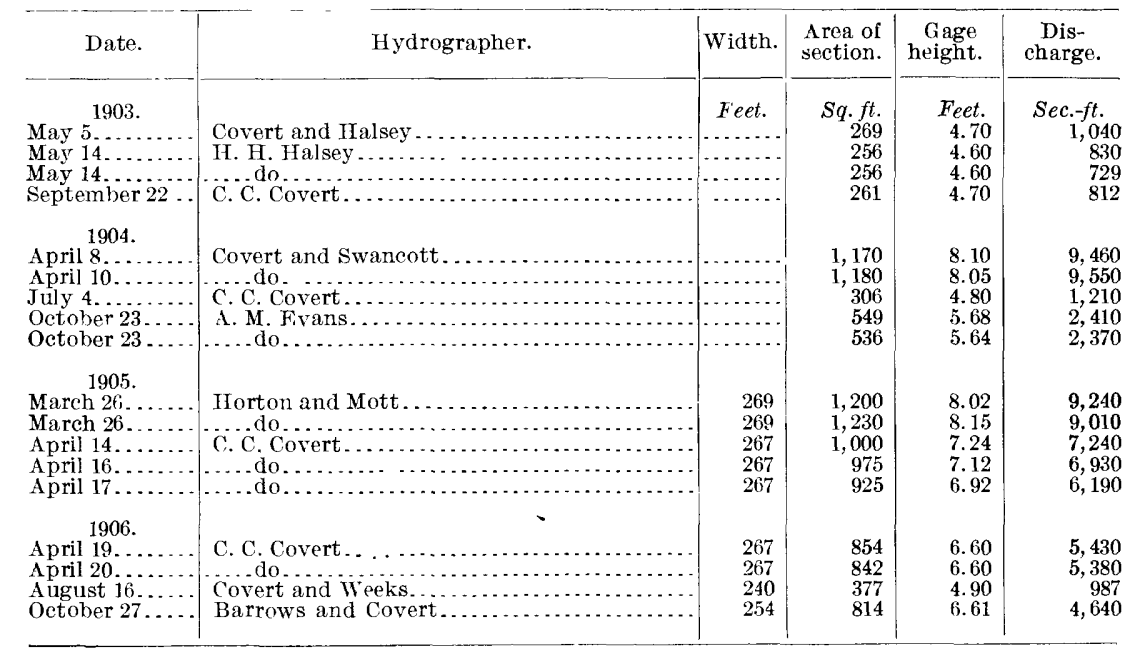

Daily gage height, in feet, of Oswegatchie River near Ogdensburg, N. Y., for 1906.

\begin{tabular}{|c|c|c|c|c|c|c|c|c|c|c|c|c|}
\hline Day. & Jan. & Feb. & Mar. & Apr. & May. & June. & July. & Aug. & Sept. & Oct. & Nov. & Dec. \\
\hline $\begin{array}{l}1 . . \\
2 . . \\
3 . . \\
4 . \\
5 .\end{array}$ & $\begin{array}{l}7.2 \\
7.4 \\
7.3 \\
7.2 \\
7.2\end{array}$ & $\begin{array}{l}7.0 \\
6.85 \\
6.5 \\
6.15 \\
6.0\end{array}$ & $\begin{array}{l}5.75 \\
5.4 \\
5.25 \\
5.25 \\
5.6\end{array}$ & $\begin{array}{l}6.8 \\
6.65 \\
6.5 \\
6.55 \\
6.3\end{array}$ & $\begin{array}{l}5.55 \\
5.4 \\
5.5 \\
5.55 \\
5.5\end{array}$ & $\begin{array}{l}5.2 \\
5.1 \\
5.1 \\
5.0 \\
5.0\end{array}$ & $\begin{array}{l}4.9 \\
4.9 \\
4.85 \\
4.9 \\
5.05\end{array}$ & $\begin{array}{l}4.7 \\
4.7 \\
4.7 \\
4.95 \\
5.1\end{array}$ & $\begin{array}{l}4.5 \\
4.5 \\
45 \\
4.5 \\
4.55\end{array}$ & $\begin{array}{l}4.65 \\
4.7 \\
4.75 \\
4.8 \\
4.8\end{array}$ & $\begin{array}{l}6.4 \\
6.35 \\
6.15 \\
6.0 \\
5.95\end{array}$ & $\begin{array}{l}6.6 \\
6.55 \\
6.45 \\
6.25 \\
6.05\end{array}$ \\
\hline $\begin{array}{r}6 \ldots \\
7 \ldots \\
8 \ldots \\
9 \ldots \\
10 \ldots\end{array}$ & $\begin{array}{l}7.1 \\
7.1 \\
7.1 \\
6.85 \\
6.8\end{array}$ & $\begin{array}{l}5.9 \\
5.7 \\
5.55 \\
5.45 \\
5.4\end{array}$ & $\begin{array}{l}5.7 \\
5.7 \\
5.65 \\
5.55 \\
5.45\end{array}$ & $\begin{array}{l}6.1 \\
6.05 \\
5.9 \\
5.9 \\
5.9\end{array}$ & $\begin{array}{l}5.7 \\
5.65 \\
5.55 \\
5.55 \\
5.5\end{array}$ & $\begin{array}{l}4.9 \\
4.8 \\
5.25 \\
5.75 \\
6.2\end{array}$ & $\begin{array}{l}5.3 \\
5.45 \\
5.55 \\
5.55 \\
5.5\end{array}$ & $\begin{array}{l}5.3 \\
5.35 \\
5.2 \\
5.1 \\
5.0\end{array}$ & $\begin{array}{l}4.75 \\
4.9 \\
4.9 \\
4.85 \\
4.8\end{array}$ & $\begin{array}{l}4.95 \\
5.1 \\
5.3 \\
5.75 \\
5.75\end{array}$ & $\begin{array}{l}5.85 \\
5.7 \\
5.7 \\
5.7 \\
5.55\end{array}$ & $\begin{array}{l}5.9 \\
5.9 \\
5.95 \\
5.95 \\
5.8\end{array}$ \\
\hline
\end{tabular}


Daily gage height, in feet, of Oswegatchie River near Ogdensburg, $N . Y$., for 1906Continued.

\begin{tabular}{|c|c|c|c|c|c|c|c|c|c|c|c|c|}
\hline Day. & Jan. & Feb. & Mar. & Apr. & May. & June. & July, & Aug. & Sept. & Oct. & Nov. & Dec. \\
\hline $\begin{array}{l}11 \ldots \\
12 \ldots \\
13 \ldots \\
14 \ldots \\
15 \ldots\end{array}$ & $\begin{array}{l}6.65 \\
6.4 \\
6.35 \\
6.2 \\
6.05\end{array}$ & $\begin{array}{l}5.3 \\
5.2 \\
5.1 \\
5.1 \\
5.1\end{array}$ & $\begin{array}{l}5.4 \\
5.25 \\
5.2 \\
5.2 \\
5.15\end{array}$ & $\begin{array}{l}5.95 \\
6.1 \\
6.15 \\
6.3 \\
6.2\end{array}$ & $\begin{array}{l}5.5 \\
5.4 \\
5.4 \\
5.35 \\
5.55\end{array}$ & $\begin{array}{l}6.4 \\
6.5 \\
6.6 \\
6.5 \\
6.4\end{array}$ & $\begin{array}{l}5.5 \\
5.4 \\
5.4 \\
5.4 \\
5.4\end{array}$ & $\begin{array}{l}5.0 \\
4.8 \\
4.8 \\
4.8 \\
4.75\end{array}$ & $\begin{array}{l}4.8 \\
4.8 \\
4.8 \\
4.8 \\
4.8\end{array}$ & $\begin{array}{l}5.75 \\
6.0 \\
6.1 \\
6.1 \\
6.15\end{array}$ & $\begin{array}{l}5.4 \\
5.4 \\
5.65 \\
5.65 \\
5.4\end{array}$ & $\begin{array}{l}5.8 \\
5.8 \\
5.65 \\
5.5 \\
5.55\end{array}$ \\
\hline $20 \ldots$ & $\begin{array}{l}5.9 \\
5.9 \\
5.85 \\
6.1 \\
5.85\end{array}$ & $\begin{array}{l}5.0 \\
5.0 \\
4.9 \\
4.9 \\
4.9\end{array}$ & $\begin{array}{l}5.1 \\
5.1 \\
5.1 \\
5.1 \\
5.0\end{array}$ & $\begin{array}{l}6.25 \\
6.25 \\
6.35 \\
6.45 \\
6.5\end{array}$ & $\begin{array}{l}5.6 \\
5.95 \\
5.95 \\
5.9 \\
5.85\end{array}$ & $\begin{array}{l}6.35 \\
6.15 \\
6.0 \\
6.0 \\
5.8\end{array}$ & $\begin{array}{l}5.4 \\
5.3 \\
5.2 \\
4.95 \\
4.9\end{array}$ & $\begin{array}{l}4.75 \\
4.7 \\
4.7 \\
4.6 \\
4.6\end{array}$ & $\begin{array}{l}4.8 \\
4.8 \\
4.7 \\
4.7 \\
4.7\end{array}$ & $\begin{array}{l}6.1 \\
6.1 \\
6.05 \\
6.0 \\
6.1\end{array}$ & $\begin{array}{l}5.45 \\
5.4 \\
5.45 \\
5.65 \\
5.7\end{array}$ & $\begin{array}{l}5.5 \\
5.7 \\
5.95 \\
6.15 \\
5.9\end{array}$ \\
\hline $\begin{array}{l}24 \ldots \\
25 \ldots \\
25 \ldots\end{array}$ & $\begin{array}{l}\mathbf{5 . 8 5} \\
6.3 \\
7.15 \\
7.45 \\
7.8\end{array}$ & $\begin{array}{l}5.0 \\
5.2 \\
5.65 \\
5.7 \\
5.8\end{array}$ & $\begin{array}{l}5.0 \\
4.95 \\
4.9 \\
4.85 \\
4.75\end{array}$ & $\begin{array}{l}6.5 \\
6.35 \\
6.3 \\
6.3 \\
6.25\end{array}$ & $\begin{array}{l}5.85 \\
5.65 \\
5.6 \\
5.55 \\
5.4\end{array}$ & $\begin{array}{l}5.65 \\
5.55 \\
5.4 \\
5.4 \\
5.4\end{array}$ & $\begin{array}{l}4.9 \\
4.9 \\
4.9 \\
4.8 \\
4.8\end{array}$ & $\begin{array}{l}4.6 \\
4.55 \\
4.45 \\
4.4 \\
4.4\end{array}$ & $\begin{array}{l}4.6 \\
4.6 \\
4.6 \\
4.6 \\
4.6\end{array}$ & $\begin{array}{l}6.1 \\
6.55 \\
6.65 \\
6.65 \\
6.7\end{array}$ & $\begin{array}{l}5.7 \\
6.6 \\
6.45 \\
6.35 \\
6.35\end{array}$ & $\begin{array}{l}5.8 \\
5.6 \\
5.8 \\
5.5 \\
5.6\end{array}$ \\
\hline $\begin{array}{l}29 \ldots \\
30 \ldots \\
31 \ldots\end{array}$ & $\begin{array}{l}7.9 \\
8.1 \\
7.95 \\
7.9 \\
7.55 \\
7.3\end{array}$ & $\begin{array}{l}5.9 \\
5.85 \\
5.85 \\
\cdots\end{array}$ & $\begin{array}{l}4.7 \\
5.0 \\
5.5 \\
6.1 \\
6.65 \\
6.8\end{array}$ & $\begin{array}{l}6.2 \\
6.2 \\
6.0 \\
5.9 \\
5.9\end{array}$ & $\begin{array}{l}5.4 \\
5.15 \\
5.2 \\
5.2 \\
5.25 \\
5.2\end{array}$ & $\begin{array}{l}5.3 \\
5.15 \\
5.1 \\
5.1 \\
4.9\end{array}$ & $\begin{array}{l}4.8 \\
4.8 \\
4.7 \\
4.7 \\
4.7 \\
4.7\end{array}$ & $\begin{array}{l}4.5 \\
4.5 \\
4.5 \\
4.5 \\
4.5 \\
4.5\end{array}$ & $\begin{array}{l}4.6 \\
4.6 \\
4.6 \\
4.75 \\
4.7\end{array}$ & $\begin{array}{l}6.7 \\
6.6 \\
6.7 \\
6.65 \\
6.45 \\
6.3\end{array}$ & $\begin{array}{l}6.3 \\
6.3 \\
6.35 \\
6.5 \\
6.55\end{array}$ & $\begin{array}{l}5.4 \\
5.3 \\
5.3 \\
5.3 \\
5.3 \\
5.3\end{array}$ \\
\hline
\end{tabular}

NoTE.--The river never freezes over at the gage owing to the swift current. Ice forming on rifts, about one-half mile below, occasionally causes backwater.

Rating table for Oswegatchie River near Ogdensburg, N. Y., for 1903-1906.

\begin{tabular}{|c|c|c|c|c|c|c|c|}
\hline $\begin{array}{c}\text { Gage } \\
\text { height. }\end{array}$ & $\begin{array}{c}\text { Dis- } \\
\text { charge. }\end{array}$ & $\begin{array}{c}\text { Gage } \\
\text { height. }\end{array}$ & $\begin{array}{l}\text { Dis- } \\
\text { charge. }\end{array}$ & $\begin{array}{c}\text { Gage } \\
\text { height. }\end{array}$ & $\begin{array}{l}\text { Dis- } \\
\text { charge. }\end{array}$ & $\begin{array}{c}\text { Gage } \\
\text { height. }\end{array}$ & $\begin{array}{c}\text { Dis- } \\
\text { charge. }\end{array}$ \\
\hline $\begin{array}{r}\text { Feet. } \\
4.40 \\
4.50 \\
4.60 \\
4.70 \\
4.80 \\
4.90 \\
5.00 \\
5.10 \\
5.20 \\
5.30 \\
5.40 \\
5.50\end{array}$ & $\begin{array}{r}\text { Sec.-ft. } \\
590 \\
680 \\
780 \\
890 \\
1,010 \\
1,140 \\
1,280 \\
1,440 \\
1,610 \\
1,790 \\
1,980 \\
2,180\end{array}$ & $\begin{array}{r}\text { Feet. } \\
5.60 \\
5.70 \\
5.80 \\
5.90 \\
6.00 \\
6.10 \\
6.20 \\
6.30 \\
6.40 \\
6.50 \\
6.60 \\
6.70\end{array}$ & $\begin{array}{r}\text { Sec.-ft. } \\
2,400 \\
2,640 \\
2,890 \\
3,160 \\
3,440 \\
3,730 \\
4,020 \\
4,310 \\
4,600 \\
4,890 \\
5,185 \\
5,480\end{array}$ & $\begin{array}{r}\text { Feet. } \\
6.80 \\
6.90 \\
7.00 \\
7.10 \\
7.20 \\
7.30 \\
7.40 \\
7.50 \\
7.60 \\
7.70 \\
7.80 \\
7.90\end{array}$ & $\begin{array}{r}S e c_{0}-f t . \\
5,775 \\
6,070 \\
6,365 \\
6,660 \\
6,955 \\
7,250 \\
7,550 \\
7,850 \\
8,150 \\
8,450 \\
8,750 \\
9,050\end{array}$ & $\begin{array}{r}\text { Feet. } \\
8.00 \\
8.20 \\
8.40 \\
8.60 \\
8.80 \\
9.00 \\
9.20 \\
9.40 \\
9.60 \\
9.80 \\
10.00\end{array}$ & $\begin{array}{r}\text { Sec.-ft. } \\
9,350 \\
9,960 \\
10,570 \\
11,180 \\
11,790 \\
12,400 \\
13,020 \\
13,640 \\
14,260 \\
14,880 \\
15,500\end{array}$ \\
\hline
\end{tabular}

Note.-The above table is applicable only for open-channel conditions. It is based on nineteen discharge measurements made during 1903-1906. Although the discharge measurements plot somewhat erratically, the curve may be considered fairly well defined owing to theconstancy of conditions of fiow from year to year.

Monthly discharge of Oswegatchie River near Ogdensburg, N. Y., for 1903-1906.

[Drainage area, 1,580 square miles.]

\begin{tabular}{l|r|r|r|r}
\hline & \\
&
\end{tabular}


Monthly discharge of Oswegatchie River near Ogdensburg, N. Y., for 1903-1906-Cont'd.

\begin{tabular}{|c|c|c|c|c|c|}
\hline \multirow{2}{*}{ Month. } & \multicolumn{3}{|c|}{ Discharge in second-feet. } & \multicolumn{2}{|c|}{ Run-off. } \\
\hline & Maximum. & Minimum. & Mean. & $\begin{array}{l}\text { Sec.-ft.per } \\
\text { sq. mile. }\end{array}$ & $\begin{array}{l}\text { Depth in } \\
\text { inches. }\end{array}$ \\
\hline 1904. & & & & & \\
\hline $\begin{array}{l}\text { January. } \\
\text { February }\end{array}$ & $\begin{array}{l}3,880 \\
1,980\end{array}$ & $\begin{array}{r}780 \\
1,280\end{array}$ & $\begin{array}{l}1,400 \\
1,610\end{array}$ & $\begin{array}{l}0.886 \\
1.02\end{array}$ & $\begin{array}{l}1.02 \\
1.10\end{array}$ \\
\hline Mareh.... & 15,300 & 1,610 & 6,150 & 3.89 & 4.48 \\
\hline April... & 14,300 & 4,160 & 7,860 & 4.97 & 5. 54 \\
\hline May. . & 5,480 & 1,790 & 3,260 & 2.06 & 2.38 \\
\hline June. - & 2,520 & 780 & 1,360 & .861 & .96 \\
\hline July... & 1,610 & 780 & 1,120 & .709 & .82 \\
\hline August .... & 1,520 & 680 & 1,020 & .646 & .74 \\
\hline September. & 3,730 & 1,140 & 1,460 & .924 & 1.03 \\
\hline October... & 5,180 & 1,980 & 3,040 & 1.92 & 2.21 \\
\hline November. & 2,890 & 780 & 1,480 & .937 & 1.05 \\
\hline December. & 1,520 & 680 & 838 & .530 & .61 \\
\hline The year. & 15,300 & 680 & 2,550 & 1.61 & 21.94 \\
\hline 1905. & & & & & \\
\hline $\begin{array}{l}\text { January.... } \\
\text { February.. }\end{array}$ & $\begin{array}{r}5,630 \\
890\end{array}$ & $\begin{array}{l}890 \\
680\end{array}$ & $\begin{array}{r}1,83 C \\
796\end{array}$ & $\begin{array}{l}1.16 \\
.504\end{array}$ & $\begin{array}{r}1.34 \\
.52\end{array}$ \\
\hline March.. & 15,800 & 680 & 3,750 & 2. 37 & 2. 73 \\
\hline April.. & 15,800 & 2,760 & 7,470 & 4.73 & 5. 28 \\
\hline May & 4,160 & 2,180 & 2,960 & 1.87 & 2.16 \\
\hline June.. & 5,480 & 1,790 & 4,000 & 2. 53 & 2.82 \\
\hline July... & 5,480 & 1,440 & 2,770 & 1.75 & 2.02 \\
\hline August & 3,730 & 1,440 & 2,310 & 1.46 & 1. 68 \\
\hline Sep & 2,400 & 1,140 & 1,710 & 1.08 & 1.20 \\
\hline October.. & 3,160 & 1,010 & 1,690 & 1.07 & 1. 23 \\
\hline November & 3,160 & 1,610 & 2,210 & 1. 40 & 1. 56 \\
\hline December. & 6,660 & 1,440 & 3,120 & 1.97 & 2. 27 \\
\hline The year. . & 15,800 & 680 & 2,880 & 1.82 & 24.81 \\
\hline Tannars & & & & & \\
\hline January.......... & $\begin{array}{l}9,660 \\
6,360\end{array}$ & 3,020 & 6,070 & 3.84 & $\begin{array}{l}\text { 4. } 43 \\
1.66\end{array}$ \\
\hline March.. & $\begin{array}{l}6,360 \\
5,780\end{array}$ & $\begin{array}{r}1,140 \\
890\end{array}$ & $\begin{array}{l}2,520 \\
2,030\end{array}$ & $\begin{array}{l}1.59 \\
1.28\end{array}$ & $\begin{array}{l}1.06 \\
1.48\end{array}$ \\
\hline April. & 5,780 & 3,160 & 4,120 & 2. 61 & 2. 91 \\
\hline May.. & 3,300 & 1,520 & 2,280 & 1.44 & 1. 66 \\
\hline June. & 5,180 & 1,010 & 2,600 & 1.65 & 1.84 \\
\hline July . & 2,290 & 890 & 1,460 & .924 & 1.07 \\
\hline August & 1,880 & 590 & 977 & .618 & .71 \\
\hline Septem & 1,140 & 680 & 886 & .561 & .63 \\
\hline October & 5,480 & 835 & 3,410 & 2.16 & 2. 49 \\
\hline Novemb & 5,180 & 1,980 & 3,320 & 2.10 & 2.34 \\
\hline December & 5,180 & 1,790 & 2.910 & 1.84 & 2. 12 \\
\hline The ycar & 9,660 & 590 & 2,720 & 1.72 & 23.34 \\
\hline
\end{tabular}

Note.-Above values 1903-1906 are rated as good.

\section{RAQUETTE RIVER BASIN.}

\section{DESCRIPTION OF BASIN.}

Raquette River drains a long, narrow basin extending from northern Hamilton County to St. Lawrence River. Its sources are on an elevated plateau, dotted with mountains interspersed with lakes. The region is timbered, but numerous marsh and swamp areas exist, many of which are on the divide and feed streams flowing in opposite directions. The lakes of the headwaters afford ample opportunities for storage development.

Observations at the dam of the Hannawa Falls Power Company were taken from September, 1902, to March 31, 1903. The discharge has not been computed. The Sunday flow of this stream, like many 
others in this State, is often held back during the low-water season while ponds at mills above are being refilled. Where there is extensive pondage of this character the resultant effect may be shown in the stream for several days.

\section{RAQUETTE RIVER AT MASSENA SPRINGS, N. Y.}

This station was established at the highway bridge at Massena Springs, September 21, 1903. Observations were continued until October 17, 1903, when the station was temporarily abandoned. It was resumed April 9, 1904. The conditions at this station and the bench marks $^{a}$ are described in Water-Supply Paper No. 170, page 94, where are given also references to publications that contain data for previous years.

Discharge measurements of Raquette River at Massena Springs, N. Y., in 1906.

\begin{tabular}{|c|c|c|c|c|c|}
\hline Date. & Ifydrographer. & Width. & $\begin{array}{l}\text { Area of } \\
\text { section. }\end{array}$ & $\begin{array}{c}\text { Gage } \\
\text { height. }\end{array}$ & Discharge. \\
\hline $\begin{array}{l}\text { April } 19 \ldots \\
\text { A pri! } 20 \ldots \\
\text { August } 14 \\
\text { August } 15 \\
\text { October } 27\end{array}$ & 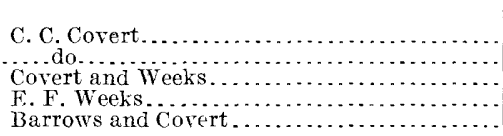 & \begin{tabular}{r|} 
Feet. \\
176 \\
176 \\
175 \\
175 \\
172
\end{tabular} & $\begin{array}{r}S q \cdot f t \\
954 \\
975 \\
581 \\
426 \\
629\end{array}$ & $\begin{array}{r}\text { Feet. } \\
5.38 \\
5.45 \\
3.38 \\
2.53 \\
3.65\end{array}$ & $\begin{array}{r}\text { Sec.-ft. } \\
3,390 \\
3,500 \\
1,440 \\
1,010 \\
1,780\end{array}$ \\
\hline
\end{tabular}

Daily gage height, in feet, of Raquette River at Massena Springs, N. Y., for 1906.

\begin{tabular}{|c|c|c|c|c|c|c|c|c|c|c|c|c|}
\hline & Jan. & Feb. & Mar. & Apr. & May. & June. & uly. & Aug. & Sept. & Oct. & Nov. & Dec. \\
\hline $\begin{array}{l}1 \ldots \\
2 \ldots \\
3 \ldots \\
4 \ldots \\
5 \ldots\end{array}$ & $\begin{array}{l}5.2 \\
4.75 \\
4.8 \\
5.7 \\
5.8\end{array}$ & $\begin{array}{l}65 \\
45 \\
25 \\
8 \\
2\end{array}$ & $\begin{array}{l}5.5 \\
5.15 \\
5.1 \\
5.0 \\
4.65\end{array}$ & $\begin{array}{l}4.0 \\
5.1 \\
5.2 \\
4.55 \\
4.15\end{array}$ & & & & & & & & $\begin{array}{l}4.0 \\
3.9 \\
4.75 \\
5.75 \\
7.0\end{array}$ \\
\hline $\begin{array}{r}6 \ldots \\
7 \ldots \\
8 \ldots \\
9 \ldots \\
10 \ldots\end{array}$ & $\begin{array}{l}5 . \\
4 . \\
5 . \\
5 . \\
5 .\end{array}$ & $\begin{array}{l}5 . \\
5 . \\
5 . \\
6 . \\
6 .\end{array}$ & & & & & & & & & & $\begin{array}{l}7.55 \\
7.9 \\
8.5\end{array}$ \\
\hline 100 & $\begin{array}{l}5.7 \\
5.55 \\
5.45 \\
4.75 \\
5.55\end{array}$ & & & & & & & & & & & $\begin{array}{l}8.05 \\
7.35 \\
7.6 \\
7.5 \\
7.5\end{array}$ \\
\hline s. & $\begin{array}{l}5.3 \\
4.95 \\
5.0 \\
5.05 \\
5.3\end{array}$ & $\begin{array}{l}5.95 \\
5.6 \\
5.8 \\
5.7\end{array}$ & & & & & & & & & & $\begin{array}{l}7.4 \\
7.7 \\
7.3 \\
6.7 \\
6.9\end{array}$ \\
\hline 4. & $\begin{array}{c}5.7 \\
9.65 \\
10.6 \\
9.05 \\
7.5\end{array}$ & $\begin{array}{l}6.0 \\
6.0 \\
5.85\end{array}$ & $\begin{array}{l}4.6 \\
4.7 \\
3.45\end{array}$ & $\begin{array}{l}6.1 \\
5.9 \\
6.0\end{array}$ & $\begin{array}{l}5.70 \\
5.65 \\
5.55 \\
5.45\end{array}$ & $\begin{array}{l}4.55 \\
4.1 \\
4.0\end{array}$ & $\begin{array}{l}3.65 \\
3.55 \\
3.4\end{array}$ & $\begin{array}{l}1.85 \\
1.8 \\
1.75 \\
1.7 \\
1.7\end{array}$ & $\begin{array}{l}1.7 \\
2.65 \\
2.7\end{array}$ & $\begin{array}{l}2.9 \\
2.9 \\
\text { 3. } 85\end{array}$ & $\begin{array}{l}3.85 \\
3.45\end{array}$ & $\begin{array}{l}6.9 \\
6.9 \\
6.9 \\
6.5 \\
5.7\end{array}$ \\
\hline
\end{tabular}

a During 1906 the rertical staff gage used in previons years was replaced by a standard chain gage, length of ehain 28.84 fect. All 1906 gage heights are referred to its datum which is 1 foot below that of the staff gage. Previous gage heights should have 1 foot added to correspond to those of 1906 . The gage was read during $1906 \mathrm{by} \mathrm{C}$. T. Buffum and $\mathrm{C}$. $\mathrm{A}$. Wait1. The lench mark is on the upstream corner of the right abitment; eleration 25.39 feet. The reference point is on the end of the needle beam. to sidewalk near the zero of gage scale; elevation 24.31 feet; elevations a re above the datum of the new gage. 


\section{LAKE CHAMPLAIN DRAINAGE BASIN.}

DESCRIPTION OF BASIN.

Lake Champlain occupies a long and narrow valley, extending in a north-south direction, and forming a part of the boundary between New York and Vermont. The elevation of the lake is about 95 feet above tide, and the water-surface area is 436 square miles.

The drainage basin is irregular in form, being about 75 miles wide from a point opposite Middlebury, Vt., northward to the outlet of the lake at Rouse Point, on the international boundary. South of Middlebury the average width of the basin is about 35 miles and the lake itself is very narrow, forming virtually a drowned river. The drainage is received almost entirely through large tributaries, there being little direct coast drainage into the lake. The outlet of the lake is Richelieu River, which flows northward from Rouse Point to St. Lawrence River.

In estimating the run-off from this basin in previous years the drainage area has been taken as 7,500 square miles. The areas of the tributary basins are given in Water-Supply Paper No. 170, pages 97-98.

The land drainage area above Rouse Point is 7,463 square miles; hence the run-off as heretofore computed represents substantially the outflow expressed as depth in inches on the land surface. As the precipitation on the lake probably exceeds the evaporation, the water surface of the lake, 436 square miles, should be added to the land area and the run-off computed for the whole drainage basin, 7,899 square miles.

The daily discharge of the lake has been determined from observations of the depth and discharge over the Chambly dam, 35 miles below the head of Richelieu River, made in 1898 by the United States Board on Deep Waterways. A rating table has been derived from the observations at the Chambly dam and the gage readings taken at Rouse Point. The area tributary to the river between Rouse Point and Chambly is 310 square miles, making the total drainage basin above Chambly 8,209 square miles.

RICHELIEU RIVER AT FORT MONTGOMERY, N. Y.

A record of the height of Lake Champlain at Rouse Point, at the head of Richelieu River, the outlet of the lake, has been kept by the United States Corps of Engineers, beginning in 1875. Through the courtesy of Capt. Harry Taylor, the gage readings taken by William McComb, the fort keeper, at 9 a. m. each day are reported weekly to the United States Geological Survey. The conditions at this station and the bench marks are described in Water-Supply Paper No. 170, page 98 , where are given also references to publications that contain data for previous years. 
Daily gage height, in feet, of Richelieu River at Fort Montgomery, N. Y., for 1906.

\begin{tabular}{|c|c|c|c|c|c|c|c|c|c|c|c|c|}
\hline Day. & Jan. & Feb. & Mar. & Apr. & May. & June. & July. & Aug. & Sept. & Oct. & Nov. & Dec. \\
\hline $\begin{array}{l}1 \ldots \\
2 \ldots \\
3 \ldots \\
4 \ldots \\
5 \ldots\end{array}$ & $\begin{array}{l}2.05 \\
2.2 \\
2.15 \\
2.3 \\
2.25\end{array}$ & $\begin{array}{l}3.55 \\
3.4 \\
3.5 \\
3.7 \\
3.35\end{array}$ & $\begin{array}{l}3.0 \\
3.05 \\
3.0 \\
3.0 \\
3.05\end{array}$ & $\begin{array}{l}3.1 \\
3.15 \\
3.2 \\
3.2 \\
3.15\end{array}$ & $\begin{array}{l}4.7 \\
4.75 \\
4.7 \\
4.75 \\
4.65\end{array}$ & $\begin{array}{l}4.3 \\
4.25 \\
4.2 \\
4.1 \\
4.05\end{array}$ & $\begin{array}{l}3.5 \\
3.65 \\
3.4 \\
3.45 \\
3.4\end{array}$ & $\begin{array}{l}2.5 \\
2.5 \\
2.5 \\
2.55 \\
2.5\end{array}$ & $\begin{array}{l}1.5 \\
1.6 \\
1.5 \\
1.45 \\
1.6\end{array}$ & $\begin{array}{l}1.1 \\
1.15 \\
1.1 \\
1.1 \\
1.1\end{array}$ & $\begin{array}{l}0.7 \\
.8 \\
.9 \\
.8 \\
.75\end{array}$ & $\begin{array}{l}1.5 \\
1.5 \\
1.5 \\
1.4 \\
1.4\end{array}$ \\
\hline $\begin{array}{r}6 \ldots \ldots \\
7 \ldots \ldots \\
8 \ldots \ldots \\
9 \ldots \ldots \\
10 \ldots .\end{array}$ & $\begin{array}{l}2.3 \\
2.25 \\
2.2 \\
2.25 \\
2.3\end{array}$ & $\begin{array}{l}3.3 \\
3.25 \\
3.3 \\
3.15 \\
3.2\end{array}$ & $\begin{array}{l}3.15 \\
3.2 \\
3.1 \\
3.05 \\
3.05\end{array}$ & $\begin{array}{l}3.2 \\
3.25 \\
3.3 \\
3.4 \\
3.4\end{array}$ & $\begin{array}{l}4.6 \\
4.5 \\
4.5 \\
4.65 \\
4.5\end{array}$ & $\begin{array}{l}4.1 \\
4.0 \\
4.15 \\
4.1 \\
4.15\end{array}$ & $\begin{array}{l}3.4 \\
3.35 \\
3.3 \\
3.4 \\
3.25\end{array}$ & $\begin{array}{l}2.45 \\
2.3 \\
2.25 \\
2.25 \\
2.4\end{array}$ & $\begin{array}{l}1.75 \\
1.6 \\
1.5 \\
1.55 \\
1.5\end{array}$ & $\begin{array}{l}1.35 \\
1.0 \\
1.05 \\
1.5 \\
.9\end{array}$ & $\begin{array}{l}.8 \\
.7 \\
.75 \\
.7 \\
.75\end{array}$ & $\begin{array}{l}1.4 \\
1.45 \\
1.5 \\
1.5 \\
1.5\end{array}$ \\
\hline $\begin{array}{l}11 \ldots \ldots \\
12 \ldots \ldots \\
13 \ldots \ldots \\
14 \ldots \ldots \\
15 \ldots \ldots\end{array}$ & $\begin{array}{l}2.25 \\
2.2 \\
2.1 \\
2.15 \\
2.2\end{array}$ & $\begin{array}{l}3.2 \\
3.15 \\
3.05 \\
3.0 \\
3.0\end{array}$ & $\begin{array}{l}3.05 \\
3.0 \\
3.05 \\
2.95 \\
2.9\end{array}$ & $\begin{array}{l}3.45 \\
3.5 \\
3.55 \\
4.1 \\
3.9\end{array}$ & $\begin{array}{l}4.4 \\
4.7 \\
4.65 \\
4.55 \\
4.65\end{array}$ & $\begin{array}{l}4.05 \\
4.1 \\
4.05 \\
4.1 \\
4.0\end{array}$ & $\begin{array}{l}3.2 \\
3.2 \\
3.3 \\
3.15 \\
3.25\end{array}$ & $\begin{array}{l}2.6 \\
2.4 \\
2.3 \\
2.05 \\
1.95\end{array}$ & $\begin{array}{l}1.55 \\
1.65 \\
1.8 \\
1.45 \\
1.3\end{array}$ & $\begin{array}{r}.9 \\
.8 \\
1.0 \\
.9 \\
.9\end{array}$ & $\begin{array}{l}.8 \\
.7 \\
.75 \\
.8 \\
.8\end{array}$ & $\begin{array}{l}1.5 \\
1.5 \\
1.55 \\
1.5 \\
1.6\end{array}$ \\
\hline $\begin{array}{l}16 \ldots \\
17 \ldots \\
18 \ldots \\
19 \ldots \\
20 \ldots\end{array}$ & $\begin{array}{l}2.4 \\
2.1 \\
2.2 \\
2.1 \\
2.4\end{array}$ & $\begin{array}{l}3.1 \\
3.05 \\
3.1 \\
3.0 \\
3.1\end{array}$ & $\begin{array}{l}2.85 \\
2.85 \\
2.75 \\
2.8 \\
2.7\end{array}$ & $\begin{array}{l}3.8 \\
4.0 \\
4.25 \\
4.3 \\
4.45\end{array}$ & $\begin{array}{l}4.7 \\
4.65 \\
4.7 \\
4.55 \\
4.5\end{array}$ & $\begin{array}{l}4.1 \\
4.1 \\
3.95 \\
3.85 \\
3.75\end{array}$ & $\begin{array}{l}3.2 \\
3.0 \\
3.0 \\
3.05 \\
3.15\end{array}$ & $\begin{array}{l}2.0 \\
2.15 \\
2.0 \\
2.0 \\
1.95\end{array}$ & $\begin{array}{l}1.45 \\
1.5 \\
1.4 \\
1.3 \\
1.3\end{array}$ & $\begin{array}{c}.75 \\
.85 \\
.8 \\
1.0 \\
.75\end{array}$ & $\begin{array}{l}.8 \\
.85 \\
1.05 \\
.95 \\
1.1\end{array}$ & $\begin{array}{l}1.45 \\
1.5 \\
1.4 \\
1.45 \\
1.45\end{array}$ \\
\hline $\begin{array}{l}21 \ldots \\
22 \ldots \\
23 \ldots \\
24 \ldots \\
25 \ldots\end{array}$ & $\begin{array}{l}2.25 \\
2.3 \\
2.45 \\
2.95 \\
3.2\end{array}$ & $\begin{array}{l}3.15 \\
3.0 \\
3.05 \\
3.2 \\
3.1\end{array}$ & $\begin{array}{l}2.8 \\
2.65 \\
2.55 \\
2.52 \\
2.5\end{array}$ & $\begin{array}{l}4.6 \\
4.7 \\
4.75 \\
4.75 \\
4.85\end{array}$ & $\begin{array}{l}4.4 \\
4.4 \\
4.4 \\
4.3 \\
4.35\end{array}$ & $\begin{array}{l}3.75 \\
3.65 \\
3.6 \\
3.6 \\
3.65\end{array}$ & $\begin{array}{l}3.0 \\
2.95 \\
2.8 \\
2.75 \\
2.6\end{array}$ & $\begin{array}{l}1.9 \\
1.8 \\
1.7 \\
1.65 \\
1.9\end{array}$ & $\begin{array}{l}1.2 \\
1.2 \\
1.15 \\
1.1 \\
1.2\end{array}$ & $\begin{array}{l}.75 \\
.8 \\
.9 \\
.9 \\
.85\end{array}$ & $\begin{array}{l}1.15 \\
1.2 \\
1.2 \\
1.2 \\
1.35\end{array}$ & $\begin{array}{l}1.4 \\
1.5 \\
1.5 \\
1.5 \\
1.45\end{array}$ \\
\hline $\begin{array}{l}26 \ldots \\
27 \ldots \\
28 \ldots \\
29 \ldots \\
30 \ldots \\
31 \ldots\end{array}$ & $\begin{array}{l}3.5 \\
3.6 \\
3.5 \\
3.55 \\
3.7 \\
3.5\end{array}$ & $\begin{array}{l}3.05 \\
3.05 \\
3.0\end{array}$ & $\begin{array}{l}2.55 \\
2.7 \\
2.55 \\
2.75 \\
2.95 \\
3.0\end{array}$ & $\begin{array}{l}4.9 \\
4.8 \\
4.85 \\
4.9 \\
4.85\end{array}$ & $\begin{array}{l}4.45 \\
4.35 \\
4.25 \\
4.3 \\
4.3 \\
4.4\end{array}$ & $\begin{array}{l}3.75 \\
3.7 \\
3.6 \\
3.7 \\
3.65\end{array}$ & $\begin{array}{l}2.75 \\
2.7 \\
2.6 \\
2.75 \\
2.8 \\
2.5\end{array}$ & $\begin{array}{l}1.85 \\
1.8 \\
1.6 \\
1.5 \\
1.55 \\
1.45\end{array}$ & $\begin{array}{l}1.4 \\
1.05 \\
1.1 \\
1.4 \\
1.05\end{array}$ & $\begin{array}{c}.9 \\
1.15 \\
1.2 \\
.9 \\
.85 \\
.7\end{array}$ & $\begin{array}{l}1.4 \\
1.3 \\
1.45 \\
1.4 \\
1.6\end{array}$ & $\begin{array}{l}145 \\
1.5 \\
1.55 \\
1.6 \\
1.6 \\
1.65\end{array}$ \\
\hline
\end{tabular}

Note.-The following ice conditions prevailed during 1906: December 6, 1905, to January 15, 1906, lake closed; ice from 0.5 to 1.0 foot thick. January 20 to February 2, lake open. February 3 , lake frozen over, no ice in channel near gage; ice about 0.3 foot thick above gage near breakwater. February 14, ice 0.65 foot thick below gage and 0.35 foot thick above gage. March 15 , channel open below gage; ice 0.35 foot thick above gage. March 31, ice all out below breakwater.

Rating table for Richelieu River at Fort Montgomery, N. Y., for 1906.

\begin{tabular}{|r|r|r|r|r|r|r|r|}
\hline $\begin{array}{c}\text { Gage } \\
\text { height. }\end{array}$ & $\begin{array}{c}\text { Dis- } \\
\text { charge. }\end{array}$ & $\begin{array}{c}\text { Gage } \\
\text { height. }\end{array}$ & $\begin{array}{c}\text { Dis- } \\
\text { charge. }\end{array}$ & $\begin{array}{c}\text { Gage } \\
\text { height. }\end{array}$ & $\begin{array}{c}\text { Dis- } \\
\text { charge. }\end{array}$ & $\begin{array}{c}\text { Gage } \\
\text { height. }\end{array}$ & $\begin{array}{c}\text { Dis- } \\
\text { charge. }\end{array}$ \\
\cline { 1 - 5 } Feet. & Sec.-ft. & Feet. & Sec.-ft. & Feet. & Sec. ft. & Feet. & Sec.-ft. \\
0.70 & 5,680 & 1.70 & 9,080 & 2.70 & 12,520 & 3.70 & 16,260 \\
0.80 & 6,020 & 1.80 & 9,420 & 2.80 & 12,880 & 3.80 & 16,640 \\
0.90 & 6,360 & 1.90 & 9,760 & 2.90 & 13,240 & 3.90 & 17,020 \\
1.00 & 6,700 & 2.00 & 10,100 & 3.00 & 13,600 & 4.00 & 17,400 \\
1.10 & 7,040 & 2.10 & 10,440 & 3.10 & 13,980 & 4.20 & 18,240 \\
1.20 & 7,380 & 2.20 & 10,780 & 3.20 & 14,360 & 4.40 & 19,080 \\
1.30 & 7,720 & 2.30 & 11,120 & 3.30 & 14,740 & 4.60 & 19,940 \\
1.40 & 8,060 & 2.40 & 11,460 & 3.40 & 15,120 & 4.80 & 20,820 \\
1.50 & 8,400 & 2.50 & 11,800 & 3.50 & 15,500 & 5.00 & 21,700 \\
1.60 & 8,740 & 2.60 & 12,160 & 3.60 & 15,880 & & \\
\hline
\end{tabular}

NotE. - The above table is based on discharge measurements made at Chambly dam in 1898 by the United States Board on Deep Waterways. 
Monthly discharge of Richelieu River at Fort Montgomery, N. Y., for 1906.

[Drainage area, 7,750 square miles.]

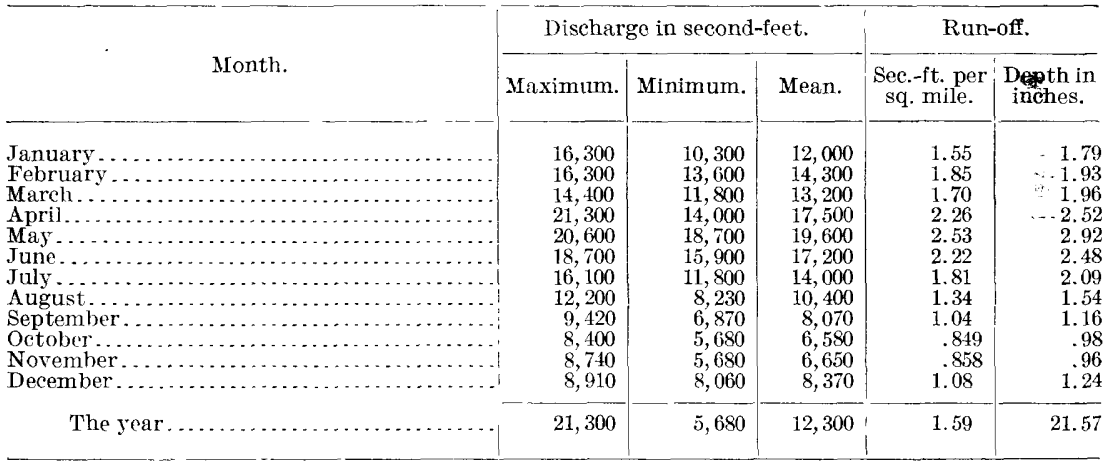

Note.-Discharge not affected hy ice conditions on the lake.

SARAYAC RIVER NEAR PLATTSBURG, N. Y.

A gaging station was established at the dam of the Plattsburg Electric Light and Power Company, 6 miles above Plattsburg, March 17, 1903. The conditions at this station and the bench marks are described in Water-Supply Paper No. 170, page 102, where are given also references to publications that contain data for previous years.

Daily discharge, in second-feet, of Saranac River near Plattsburg, N. Y., for 1906.

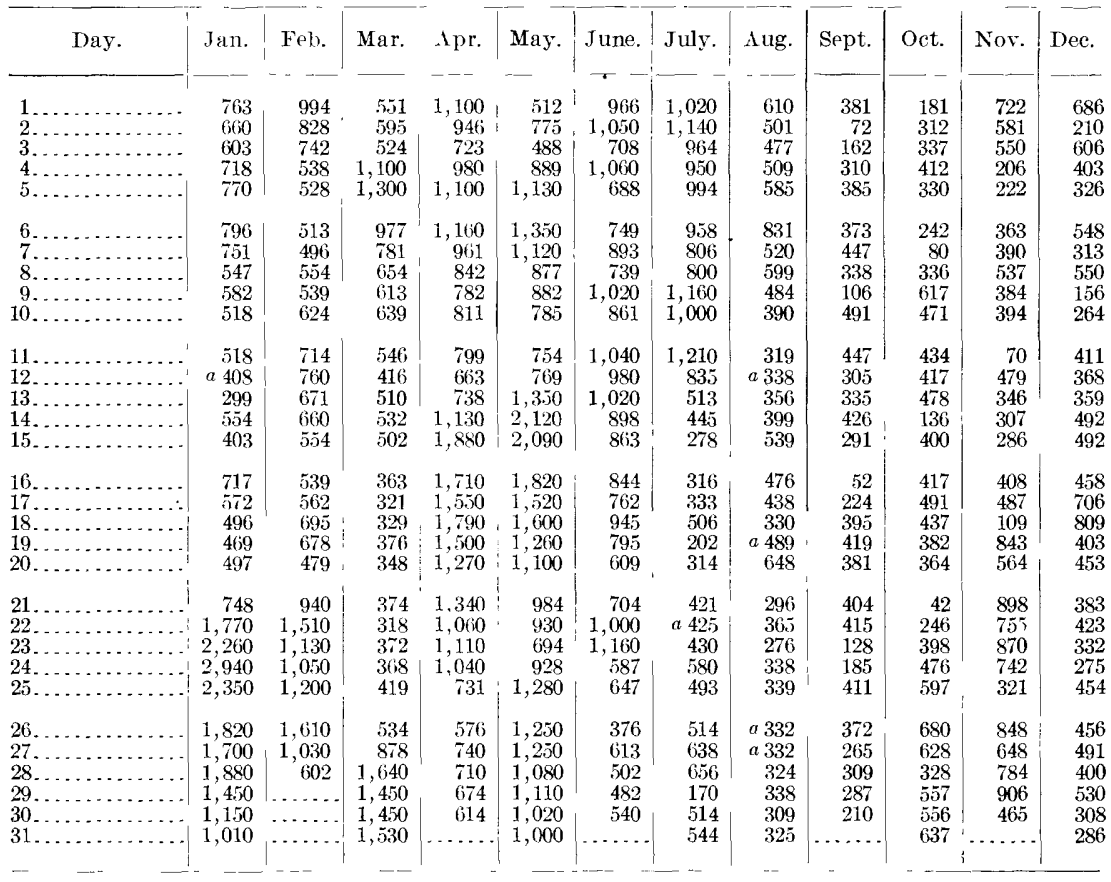

a Discharge interpolated.

Note.--During January, February, March, and December the dam is slightly obstructed by ice, and discharges are liable to error. 
Monthly discharge of Saranae River near Plattsburg, V. Y., for 1906.

[Drainage area, 624 square miks.]

\begin{tabular}{|c|c|c|c|c|c|c|}
\hline \multirow{2}{*}{$\begin{array}{l} \\
\ldots \\
\ldots\end{array}$} & \multirow[b]{2}{*}{ Month. } & \multicolumn{3}{|c|}{ Diseharge in sccond-feet. } & \multicolumn{2}{|c|}{ Rum-off. } \\
\hline & & Maximum. & Minimum. & Mean. & $\begin{array}{l}\text { Sec.-it. per } \\
\text { sq. mile. }\end{array}$ & $\begin{array}{l}\text { Depth in } \\
\text { inches. }\end{array}$ \\
\hline & 2,940 & 299 & 991 & 1.59 & 1.83 \\
\hline & & 1,610 & 513 & 776 & 1.24 & 1. 29 \\
\hline & 1,640 & 318 & 687 & 1.10 & 1.27 \\
\hline \multirow{2}{*}{\multicolumn{2}{|c|}{ 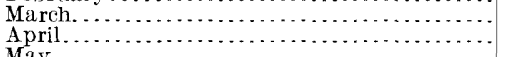 }} & 1,790 & 576 & 1,030 & 1.65 & 1.84 \\
\hline \multirow{2}{*}{\multicolumn{2}{|c|}{ 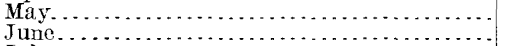 }} & 2,090 & 488 & 1,120 & 1. 79 & 2.06 \\
\hline & & 1,160 & 376 & 803 & 1. 29 & 1. 44 \\
\hline \multicolumn{2}{|c|}{$\begin{array}{l}\text { June } \\
\text { July } \ldots \ldots \ldots \ldots \ldots\end{array}$} & 1,210 & 17 & 649 & 1.04 & 1. 20 \\
\hline \multirow{2}{*}{\multicolumn{2}{|c|}{ 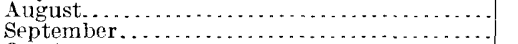 }} & 831 & 276 & 436 & .699 & .81 \\
\hline & & 491 & 52 & 311 & .498 & .57 \\
\hline \multicolumn{2}{|c|}{ 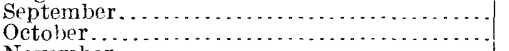 } & 680 & 42 & 401 & .643 & .74 \\
\hline \multirow{2}{*}{\multicolumn{7}{|c|}{ 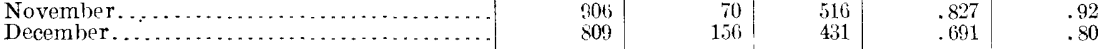 }} \\
\hline & & \multicolumn{5}{|c|}{ 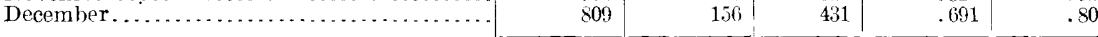 } \\
\hline \multicolumn{2}{|c|}{ The year. } & 2,940 & 42 & 679 & 1.09 & 14.76 \\
\hline
\end{tabular}

Note.-Yalues are rated as follows: January to March and December, good: April to November, excellent.

\section{OTTER CREEK AT MIDDLEBURY, VT.}

This station was established April 1, 1903, by H. K. Barrows. It is located at the railway bridge about one-half mile south of the railway station at Middlebury, Vt. The conditions at this station and the bench marks are described in Water-Supply Paper No. 170, page 106 , where are given also references to publications that contain data for previous years.

Discharge measurements of Otter Creek at Middlebury, Vt., in 1905-6.

\begin{tabular}{|c|c|c|c|c|c|}
\hline Date. & IIydrographer. & Width. & $\begin{array}{l}\text { Area of } \\
\text { section. }\end{array}$ & $\begin{array}{c}\text { Gage } \\
\text { height. }\end{array}$ & Diseharge. \\
\hline $\begin{array}{r}190 \pi . \\
\text { March } 29 a\end{array}$ & Butterfield and Brett. & Feet. & $S q . f t$. & Feet. & Sec.-ft. \\
\hline April 1 a... & A. D. Butterficld... & 120 & 711 & 16.72 & 4,900 \\
\hline April $4 a$. & $\ldots$ do $\ldots . . . . .$. & 120 & 768 & 17,22 & 5,560 \\
\hline April $10 a$. & ....do.. & 120 & 581 & 15.52 & 3,750 \\
\hline$A$ pril $10 b$. & ....do. & 189 & 1,520 & 15.50 & 3,430 \\
\hline May $1 a . .$. & Butterfield and Brett. & 120 & 367 & 13. 40 & 1,370 \\
\hline May $12 a .$. & G. M. B rett............. & 118 & 334 & 12.90 & 946 \\
\hline 1906 & & & & & \\
\hline March 10 & II. K. Barrows... & 10 & 352 & 13.40 & 1,160 \\
\hline April 14. & G. M. Brett .... & 133 & 465 & 14. 25 & 2,100 \\
\hline $\begin{array}{l}\text { September } \\
\text { Noyember }\end{array}$ & A. D. Butterfield.. & 117 & 229 & 12.35 & 316 \\
\hline November & ......do............. & $118 !$ & 229 & 12.27 & 344 \\
\hline
\end{tabular}

a From arch bridge.

$b$ From railroad bridge.

$c$ River frozen at gage, but open 500 fect below gage for some 800 feet to arch bridge and dam. Gage height to bottom of ice, 12.77 feet; average thickness of ice, 0.70 foot.

Daily gage height, in feet, of Otter Creek at Middlebury, Vt., for 1906.

\begin{tabular}{|c|c|c|c|c|c|c|c|c|c|c|c|c|}
\hline Day. & Jan. & Feb. & Mar. & Apr. & May. & June. & July. & Aug. & Sept. & Oct. & Nov. & Dec. \\
\hline $\begin{array}{l}1 . \\
2 . \\
3 . \\
4 . \\
5 .\end{array}$ & & $\begin{array}{l}13.4 \\
13.2\end{array}$ & 13.2 & $\begin{array}{l}15.6 \\
15.5 \\
15.15 \\
14.75 \\
14.45\end{array}$ & $\begin{array}{l}14.0 \\
13.75 \\
14.0 \\
14.45 \\
14.5\end{array}$ & $\begin{array}{l}15.45 \\
15.5 \\
15.55 \\
15.3 \\
14.9\end{array}$ & $\begin{array}{l}13.95 \\
14.2 \\
13.8 \\
13.4 \\
13.6\end{array}$ & $\begin{array}{l}13.2 \\
12.8 \\
12.6 \\
12.5 \\
12.65\end{array}$ & $\begin{array}{l}12.6 \\
12.4 .5 \\
12.35 \\
12.7 \\
12.6\end{array}$ & $\begin{array}{l}12.2 \\
12.8 \\
12.3 \\
12.3 \\
12.2\end{array}$ & $\begin{array}{l}12.6 \\
12.6 \\
12.5 \\
12.5 \\
12.35\end{array}$ & $\begin{array}{l}12.85 \\
12.8 \\
12.55\end{array}$ \\
\hline $\begin{array}{r}6 \ldots \\
7 \ldots \\
8 \ldots \\
9 \ldots \\
10 \ldots\end{array}$ & 13.4 & 13.2 & & $\begin{array}{l}14.6 \\
14.5 \\
14.2 \\
13.9 \\
13.7\end{array}$ & \begin{tabular}{|l}
14.4 \\
14.1 \\
13.8 \\
13.5 \\
14.15
\end{tabular} & $\begin{array}{l}14.25 \\
13.9 \\
14.1 \\
14.5 \\
14.5\end{array}$ & $\begin{array}{l}13.4 \\
13.1 \\
12.85 \\
12.7 \\
12.8\end{array}$ & $\begin{array}{l}12.9 \\
13.15 \\
13.0 \\
12.75 \\
12.55\end{array}$ & $\begin{array}{l}12.5 \\
12.4 \\
12.4 \\
12.4 \\
12.1\end{array}$ & $\begin{array}{l}12.15 \\
12.1 \\
12.0 \\
12.1 \\
12.2\end{array}$ & $\begin{array}{l}12.4 \\
12.4 \\
12.35 \\
12.3 \\
12.3\end{array}$ & \\
\hline
\end{tabular}


Daily gage height, in feet, of Otter Creek at Middlebury, Vt., for 1906-Continued.

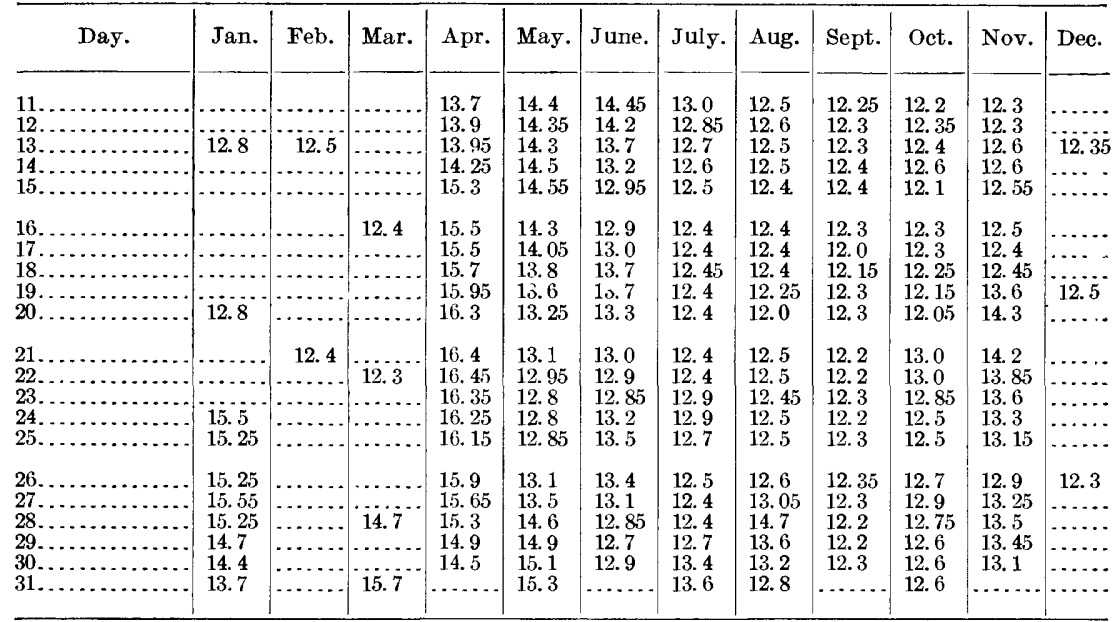

NoTe.-Creek was frozen January 1 to 24, February 3 to March 31, and December 3 to 31 . During the frozen period gage heights were taken to water surface through a hole in the ice. The following comparative readings were taken:

Comparative ice and water readings.

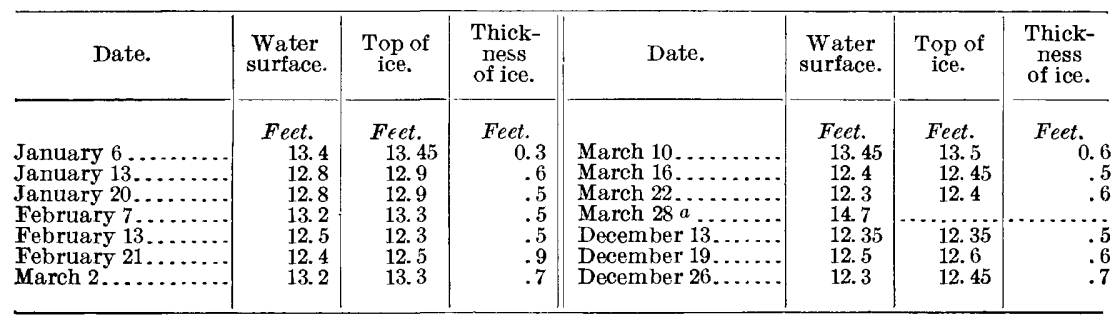

$a$ Water flowing on top of ice.

Rating table for Otter Creek at Middlebury, Vt., for 1905-6.

\begin{tabular}{|c|r|r|r|r|r|r|r|}
\hline $\begin{array}{c}\text { Gage } \\
\text { height. }\end{array}$ & $\begin{array}{c}\text { Dis- } \\
\text { charge. }\end{array}$ & $\begin{array}{c}\text { Gage } \\
\text { height. }\end{array}$ & $\begin{array}{c}\text { Dis- } \\
\text { charge. }\end{array}$ & $\begin{array}{c}\text { Gage } \\
\text { height. }\end{array}$ & $\begin{array}{c}\text { Dis- } \\
\text { charge. }\end{array}$ & $\begin{array}{c}\text { Gage } \\
\text { height. }\end{array}$ & $\begin{array}{c}\text { Dis- } \\
\text { charge. }\end{array}$ \\
\hline Feet. & Sec.-ft. & Feet. & Sec.-ft. & Feet. & Sec.-ft. & Feet. & Sec.-ft. \\
$12: 00$ & 220 & 13.10 & 1,030 & 14.20 & 2,080 & $\mathbf{1 5 . 6 0}$ & 3,610 \\
12.10 & 275 & 13.20 & 1,120 & 14.30 & 2,180 & 15.80 & 3,830 \\
12.20 & 335 & 13.30 & 1,210 & 14.40 & 2,290 & 16.00 & 4,070 \\
12.30 & 400 & 13.40 & 1,300 & 14.50 & 2,400 & 16.20 & 4,310 \\
12.40 & 470 & 13.50 & 1,390 & 14.60 & 2,510 & 16.40 & $\mathbf{4}, 550$ \\
12.50 & 540 & 13.60 & 1,480 & 14.70 & 2,620 & 16.60 & 4,790 \\
12.60 & 615 & 13.70 & 1,580 & 14.80 & 2,730 & 16.80 & 5,030 \\
12.70 & 695 & 13.80 & 1,680 & 14.90 & 2,840 & 17.00 & 5,270 \\
12.80 & 775 & 13.90 & 1,780 & 15.00 & 2,950 & 17.20 & 5,510 \\
12.90 & 860 & 14.00 & 1,880 & 15.20 & 3,170 & 17.40 & 5,750 \\
13.00 & 945 & 14.10 & 1,980 & 15.40 & 3,390 & & \\
\end{tabular}

Note.-The above table is applicable only for open-chamel conditions. It is based on discharge measurements made during 1905-6, and is well defined between gage heights 13.0 feet and 18.0 feet. Mean monthly discharge computed from the above should be reasonably close, but daily discharges for gage heights below 13.0 feet are liable to considerable error. Fluctuations caused by the dam below render variable the relation between gage height and the elevation of the water surface at the measuring section. 
Monthly discharge of Otter Creek at Middlebury, Vt., for 1905-6.

[Drainage area, 615 square miles.]

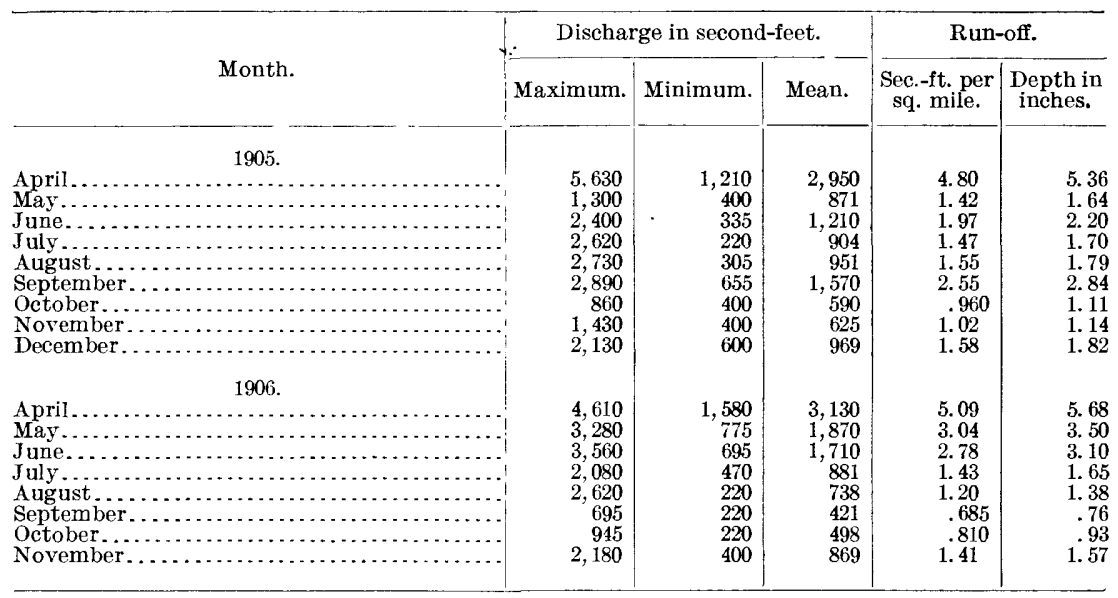

Note.-Values are rated as follows: October to December, 1905, September and October, 1906, fair; all others, good.

\section{WINOOSKI RIVER AT RICHMOND, VT.}

This station was established June 25, 1903, by H. K. Barrows, at the steel highway bridge one-fourth mile south of the railway station at Richmond, Vt. The conditions ${ }^{a}$ at this station and the bench marks are described in Water-Supply Paper No. 170, page 108 , where are given also references to publications that contain data for previous years.

Discharge measurements of Winooski River at Richmond, Vt., in 1906.

\begin{tabular}{|c|c|c|c|c|c|}
\hline Date. & IIydrographer. & Width. & $\begin{array}{l}\text { Area of } \\
\text { section. }\end{array}$ & $\begin{array}{c}\text { Gage } \\
\text { height. }\end{array}$ & Discharge. \\
\hline March $9 b$ & H. K. Barrow & $\begin{array}{r}\text { Feet. } \\
70\end{array}$ & $S q \cdot f t$. & $\begin{array}{l}\text { Feet. } \\
5.53\end{array}$ & Sec.-ft. \\
\hline March 29. & A. D. Butterfiel & 182 & 1,590 & 6.96 & 3,190 \\
\hline April 13... & ..... do ...... & 182 & 1,470 & 6.57 & 3,500 \\
\hline April $18 . .$. & Butterfield and Ny & 183 & 1,960 & 9.55 & 9,180 \\
\hline April 25. & A. D. Butterfield. & 180 & 1,430 & 6.50 & 3,380 \\
\hline April 25. & G. M. Brett. & 180 & 1,430 & 6.50 & 3,210 \\
\hline May 23. . & Butterfield and Brett & 180 & 1,130 & 4.97 & 1,240 \\
\hline May 23. & $\ldots$ do $\ldots$. & 180 & 1,130 & 4.97 & 1,290 \\
\hline September 25. & A. D. Butterfield. & 145 & 180 & 3. 92 & 389 \\
\hline November $30 .$. & .....do... & 178 & 1,110 & 5.10 & 1,350 \\
\hline
\end{tabular}

$a$ Length of chain, 29.47 feet. Gage datum is at elevation 287.63 feet above mean sea level, as determined during 1906 by connecting with the aluminum tablet bench mark of United States Geological Survey in Universalist church foundation.

$b$ River frozen at gage; channel open 1,000 feet upstream and one-half mile downstream. Ice very rough, broken, and tifted, reaehing to bottom for about two-thirds of section. Gage height is to water surface; gage height to bottom of ice about 3.4 feet; average thickness of ice about 2.8 feet. 
Daily gage height, in feet, of Winooski River at Richmond, Vt., for 1906.

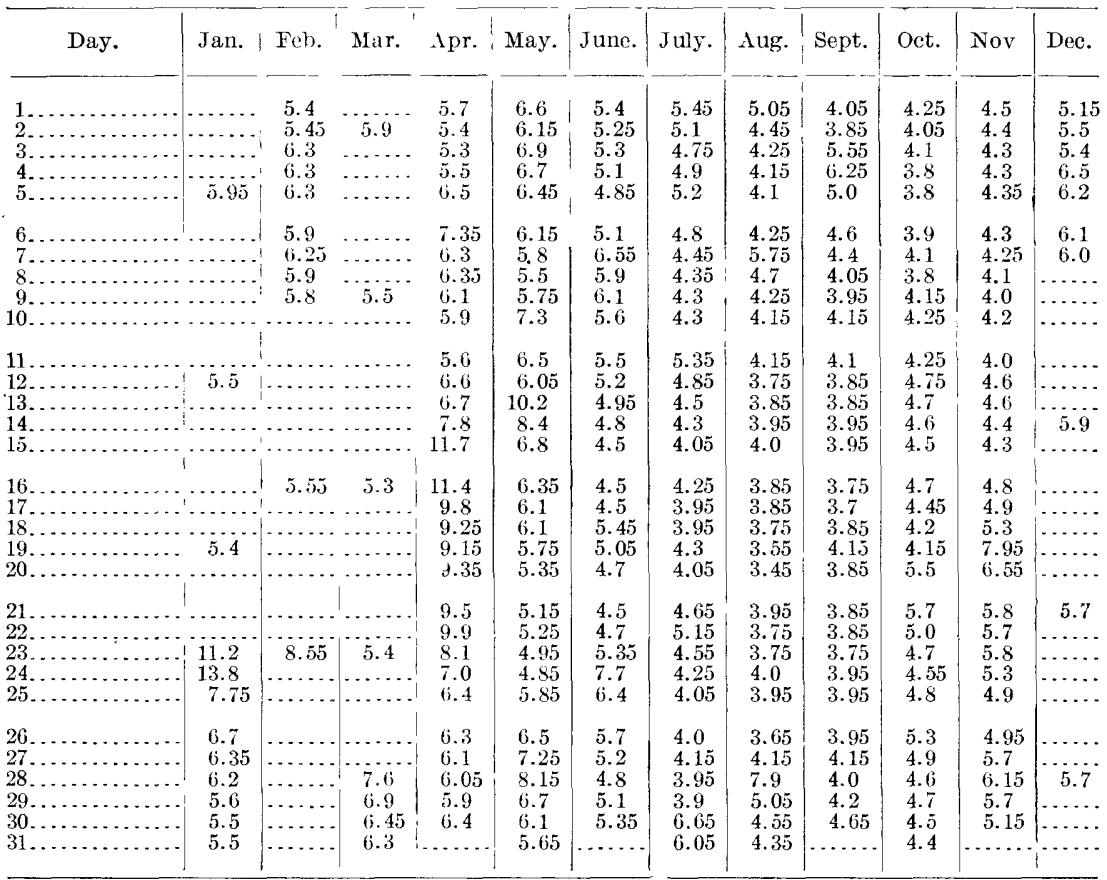

Note.-River frozen January 1 to 22, February 7 to March 28, nd December 4 to 31 . During the frozen period gage heights were taken to water surface through a hole in the ice. The following comparative readings were taken:

Comparative ice and water readings.

\begin{tabular}{|c|c|c|c|c|c|c|c|}
\hline Date. & $\begin{array}{c}\text { Water } \\
\text { surface. }\end{array}$ & $\begin{array}{l}\text { Top of } \\
\text { ice. }\end{array}$ & $\begin{array}{l}\text { Thick- } \\
\text { ness of } \\
\text { ice. }\end{array}$ & Date. & $\begin{array}{l}\text { Water } \\
\text { surface. }\end{array}$ & $\begin{array}{c}\text { Top of } \\
\text { ice. }\end{array}$ & $\begin{array}{l}\text { Thick- } \\
\text { ness of } \\
\text { ice. }\end{array}$ \\
\hline $\begin{array}{l}\text { January } 5 a \ldots \\
\text { January } 12 \ldots \\
\text { January } 19 \ldots \\
\text { March } 9 b \ldots\end{array}$ & $\begin{array}{l}\text { Feet. } \\
\quad 5.95 \\
\quad 5.5 \\
5.4 \\
5.5\end{array}$ & $\begin{array}{l}\text { Feet. } \\
\quad 5.7 \\
5.65 \\
5.55 \\
\quad 6.2\end{array}$ & $\begin{aligned} & \text { Feet. } \\
& 1.1 \\
& 1.3 \\
& 1.4 \\
& 2.8\end{aligned}$ & $\begin{array}{l}\text { December } 7 \ldots \ldots \ldots \\
\text { December } 14 \ldots \ldots . \\
\text { Deeember } 21 \ldots \ldots \\
\text { December } 28 \ldots \ldots\end{array}$ & $\begin{array}{l}\text { Feet. } \\
6.0 \\
5.9 \\
5.7 \\
5.7\end{array}$ & $\begin{array}{c}\text { Feet. } \\
\quad 6.15 \\
\quad 6.1 \\
5.95 \\
\quad 5.9\end{array}$ & $\begin{array}{l}\text { Feet. } \\
0.8 \\
1.4 \\
1.5 \\
1.5\end{array}$ \\
\hline
\end{tabular}

$a$ Water on top of ice

$b$ During the period from about January 23 to March 28 gage heights give little or no indication of discharge owing to an ice jam at the bridge. Sce note to measurement made March 9, 1906 . 
Rating table for Winooski Ruer at Richmond; Vt., for 1906.

\begin{tabular}{|c|c|c|c|c|c|c|c|}
\hline $\begin{array}{c}\text { Gage } \\
\text { height. }\end{array}$ & $\begin{array}{c}\text { Dis- } \\
\text { charge. }\end{array}$ & $\begin{array}{c}\text { Gage } \\
\text { height. }\end{array}$ & $\begin{array}{c}\text { Dis- } \\
\text { charge. }\end{array}$ & $\begin{array}{c}\text { Gage } \\
\text { height. }\end{array}$ & $\begin{array}{c}\text { Dis- } \\
\text { charge. }\end{array}$ & $\begin{array}{l}\text { Gage } \\
\text { height. }\end{array}$ & $\begin{array}{l}\text { Dis- } \\
\text { charge. }\end{array}$ \\
\hline Feet. & Sec.-ft. & Feet. & Sec.-ft. & Feet. & Sec.-ft. & Feet. & $s e c-f t$. \\
\hline 3.40 & 215 & 4.80 & 1,060 & 6.20 & 2,830 & 8.20 & 6,350 \\
\hline 3.50 & 235 & 4.90 & 1,165 & 6.30 & 2,980 & 8.40 & 6,750 \\
\hline 3.60 & 260 & 5.00 & 1,275 & 6.40 & 3,140 & 8.60 & 7,160 \\
\hline 3.70 & 290 & 5.10 & 1,385 & 6.50 & 3,300 & 8.80 & 7,580 \\
\hline 3.80 & 330 & 5.20 & 1,500 & 6.60 & 3,460 & 9.00 & 8,000 \\
\hline 3.90 & 380 & 5. 30 & $1,61.5$ & 6.70 & 3,620 & 9.20 & 8,420 \\
\hline 4.00 & 435 & 5.40 & 1,735 & 6.80 & 3,790 & 9.40 & 8,840 \\
\hline 4.10 & 495 & 5.50 & 1,860 & 6.90 & 3,960 & 9.60 & 9,270 \\
\hline 4.20 & 560 & 5.60 & 1,985 & 7.00 & 4,130 & 9.80 & 9,710 \\
\hline 4.30 & 630 & 5.70 & 2,115 & 7.20 & 4,470 & 10.00 & 10,150 \\
\hline 4.40 & 705 & 5.80 & 2,250 & 7.40 & 4,830 & 11.00 & 12,400 \\
\hline 4.50 & 785 & 5.90 & 2,390 & 7.60 & 5.190 & 12.00 & 14,700 \\
\hline 4. 60 & 870 & 6.00 & 2,530 & 7.80 & 5,570 & & \\
\hline 4.70 & 900 & 6.10 & 2,680 & 8.00 & 5,950 & & \\
\hline
\end{tabular}

Note.-The above table is applicable only for open-channel conditions. It is based on discharge measurements made during 1906 and the form of previous curves. It is well defined between gage heights 3.9 feet and 10.0 feet. An increase in discharge for a given gage height is taking place at triis station from year to year. These yearly changes may be due to the scouring effect of ice jams.

Monthly discharge of Winooski River at Richmond, Vt., for 1906.

[Drainage arca, 885 square miles.]

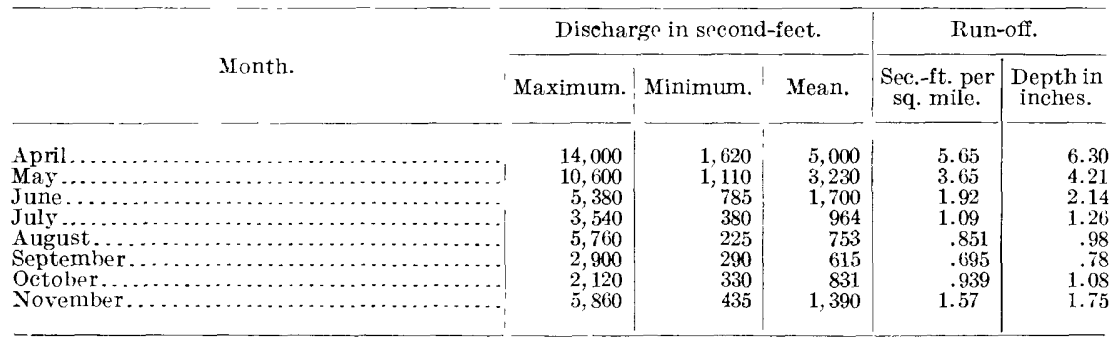

Note.-Values are rated as follows: April to June, good; July to November, fair.

IRR $206-07-7$ 


\section{N D E X.}

A. Page.

Acknowledgments

Acre-foot, definition of Albion, Mich.,

Reed's springs near:

description.

gage heights. . . . . . . . . . . . .

Allegan, Mich.

Kalamazoo River near:

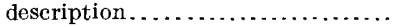

discharge, daily.

discharge, monthly ............. Alloway, N. Y.,

Canandaigua Outlet at:

description.

gage heights.

Au Sable River at-

Bamfield, Mich.:

description . ..................

discharge, monthly.

gage heights.

rating table.

\section{B.}

Baldwinsville, N. Y.,

Seneca River at:

description

discharge, daily................

discharge, monthly

Bamfield, Mich.,

Au Sable River near:

description...

discharge, monthly . ............

gage heights.

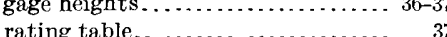

Barrows, H. K., work in charge of .... ...

Battle Island, N. Y.,

Oswego River at:

description.

$62-63$

discharge, monthly.

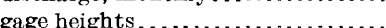

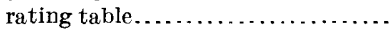

Black River (of Lake Erie) near-

Elyria:

description

discharge

discharge, monthly ..............

gage heights..................

iating table

Black River (of Lake Ontario) near-

Felts Mills, N. Y.

description....

discharge, daily. .

discharge, monthly.
Black River (of Lake Ontario) basin: Page. deseription......................... 75

Bolster, R. H., work of ............... 1

Brennan, M. S., work of ............... 1

Buchanan, Mich.

St. Joseph River near:

deseription.................... 27

discharge, daily................ 27-28

discharge, monthly.............. $\quad 27$

C.

Cable station, figure showing.......... 11

Canadice Lake outlet near-

Hemlock, N. Y.:

description................... $\quad 60$

discharge, monthly .............. 61

Canandaigua Outlet at-

Alloway, N. Y.

description.................... 63-64

gage heights..................... 64

Cayuga Lake at-

Ithaca, N. Y.

description................... 66

gage heights................. 66

Champlain, Lake, drainage basin: description.................... $\quad 84$

Chittenango Creek at-

Chittenango, N. Y.:

description.................. 71

discharge...................... 71

discharge, monthly.............. $\quad 72$

gage heights . . . . . . . . . . . . . . 71

rating table..................... 72

Computation, methods of. . . . . . . . . . 13-16

Cooperation, acknowledgments for ....... 16

Covert, C. C., work of ................. 1

Crivitz, Wis.,

Peshtigo River at:

description ..................... 20-21

discharge.................... 21

gage heights.................. 21

Peshtigo River near:

description.................. 21-22

discharge...................... 22

discharge, month]y ............. $\quad 22$

gage heights .................. $\quad 22$

rating table..........................

Current meters, classes of . . . . . . . . . . . 10

methods of using. ................. 10-11

plate showing.................... 10

Current meter station, view of . . . . . . . . . . 10

Curves (discharge, area, and velocity), figure showing .............. 15 
Cuyahoga River at-

Independence, Ohio:

description.

Page.

discharge.........

gage heights ................. 53-54

Cuyahoga River basin:

description.

\section{D.}

Defiance, Ohio,

Tiffin River near:

description.

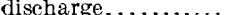

discharge, monthly.

gage beights....................

rating table. Dexter, Mich.

Huron River at:

description...................

gage heights.................. 41-42

Discharge, methods of measuring and computing...................... 13-16

Drainage basins, list of ................. $\quad 2-3$

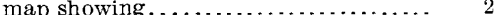

Dugan, D. II., work of ................ 1

East Rush, N. Y.

E.

Honeoye Creek at:

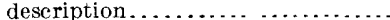

discharge, daily...

discharge, monthly ..

Elyria, Ohio,

Black River (of Lake Erie) near

description.....................

discharge......................

discharge, monthly.

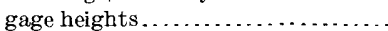

rating table......................

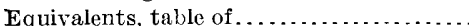

Erie, Lake, drainage:

general features................... 40

station data....................... 41-54

Escanaba River near-

Escanaba, Mich.:

description...................... 17

discharge. .....

diseharge, monthly............. 18

gage heights................... 17

rating table...................... 18

Euclid, N. Y.,

Oneida River near:

description.

discharge, daily.................

discharge, monthly

F.

Felts Mills, N. Y.,

Black River near:

description...

discharge, daily................. $75-76$

discharge, monthly ............... 76

Flatrock, Mich.

Huron River at:

description.

discharge

discharge, monthly

gage heights.

Gaging stations, equipment of .

location of, map showing.

Floats, use of, in measuring discharge Page.

Follansbee, Robert, work of ............. 1

Fort Montgomery, N. Y.,

Richelieu Riyer at:

description.................... 84

discharge, monthly.............. 85

gage heights.................. 85

rating table.....................

Fort Wayne, Ind.,

St. Joseph (of the Maumee) River at:

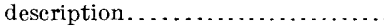

discharge........................

discharge, monthly ..............

gage heights.....................

rating table..

St. Marys River at:

deseription.

discharge, monthly .............. 49

gage heights................... 48

rating table..................... 48

Freeland, Mich.

Tittabawassee River at:

description.................... 39

discharge..................... 39

gage heights.................. $39-40$

Geddes, Mich.,

Huron River at:

description.

Genesee River at or near-

High dam near Mount Morris, N. Y.: description.................. $57-58$

Mount Morris, N. Y.:

description..................... 56

discharge..................... 56

discharge, monthly.............. 57

gage heights.................. $\quad 56$

rating table ........................ 57

Rochester, N. Y.:

description.................... 58

discharge..................... 58

discharge, monthly ............... $\quad 60$

gage heights................... 58

rating table.................... 59

Genesee River basin:

description.................. 54-5j

Geneva, N. Y.,

Seneca Lake at:

description...................64-65

gage heights..................... 65

Gillett, Wis.

Oconto River at:

description.................... 23

discharge...................... 23

gage heights................... 23-24

Grand River at-

Grand Rapids, Mich.

description..................... 32

discharge....................... 32

gage heights................... $32-33$ 
Grand River at-

North Lansing, Mich.:

description.

discharge ................

discharge, monthly.

gage heights .

rating table.

Grand River basin, Mich.:

description.

II.

Hemlock, N. Y.

Canadice Lake outlet near:

description................... 60

discharge, monthly ..............

Henshaw, F. F., work of.

Honeoye Creek at-

East Rush, N. Y.:

description....

Horsepower, ealculation of...............

Horton, A. H., work in charge of.

Horton, R. E., work of . ................

Hoyt, J. C., work of.

Huron, Lake, drainage:

general features.

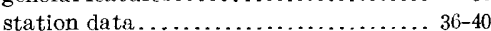

Huron River at-

Dexter, Mich.

description.

gage heights

41

Flatrock, Mich :

description. . . . . . . . . . . . . . . . $42-43$

discharge..................... 43

discharge, monthly.............. 44

gage heights................. 43

rating table...................... 43

Geddes, Mich.:

description.....................

discharge, monthly

Huron River basin:

description.

Iydrographic surveys, organization and scope of.

\section{I.}

Ice-covered streams, method of measuring flow of...

Independence, Ohio,

Cuyahoga River at:

description.

discharge....

gage heights

ountain, Mich.

Menominee River near:

deseription.

discharge..................... 18

discharge, monthly ..............

gage heights.

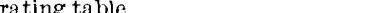

Ithaca, N. Y.,

Cayuga Lake at:

description..

gage heights....................
Kalamazoo River near-

dllegan, Mich.:

description................... 28

discharge, daily................ 28

discharge, monthly .............. 28

Ka!amazoo River basin: description................... 28

Kenwood, N. Y.,

Oneida Creek at:

description................... 70

gage heights................... 70

I.

Lakes. See particular names.

Manistee River near-

M.

Sherman, Mich.:

description................... 35

discharge.................... 35

gage heights.................. 35

Manistee River basin: description...

Massena Springs, N. Y.

Raquette River at:

description.

discharge, monthly.............. 83

gage heights.................. $82-83$

rating table........... 83

Maumee River near-

Sherwood, Ohio:

description..................... 44

discharge...................... 44

discharge, monthly.............. 45

gage heights.................... 44-45

rating table....................... 45

Maumee River basin:

description..................... 44

Mendon, Mich.

St. Joseph River near:

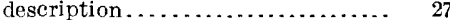

discharge...................... 27

Menominee River near-

Iron Mountain, Mich.:

description.................... 18

discharge...................... 18

discharge, monthly.............. $\quad 20$

gage heights................... 19

rating table..................... 19

Michigan, Lake, drainage:

generaI features . . . . . . . . . . . . . . . . 16-17

station data...................... 17-35

Middlebury, Vt.,

Otter Creek at:

description................... 87

discharge....................... 87

discharge, monthly............ $\quad 89$

gage heights................... $87-88$

rating table................... 88

Miner's inch, definition of ...............

Moose River at-

Moose River, N. Y.

description.................. 76

discharge.................... $\quad 76$ 
Moose River at-

Moose River N. Y.-Continued.

discharge, monthly. .

gage heights....................

rating table.......................

Mount Morris, N. Y.,

Genesee River at high dam near: description..................... $57-58$

Genesee River near:

description.

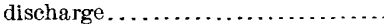

discharge, monthly ...............

gage heights.....................

rating table.

Multiple-point method of measuring discharge, description of.......... 11-12

Muskegon River at-

Newaygo, Mich.:

description.....................

discharge, daily.................

discharge, monthly ...............

Muskegon River basin:

description.

N.

Newaygo, Mich.,

Muskegon River at:

description.....

discharge, daily .........

discharge, monthly ...............

North Lansing, Mich.,

Grand River at:

description.

discharge............

discharge, monthly ...............

gage heights .......................

rating table.

o.

Oconto River at-

Gillett, Wis.:

description.................... 23

discharge....................... 23

gage heights.................... 23-24

Stiles, Wis.:

description.................... 24

discharge... . . . . . . . . . . . . . . . 24

gage heights................... 24

Oconto River basin: description.

Ogdensburg, N. Y.,

Oswegatchie River near:

description.................... $\quad 79$

discharge.................... 79

discharge, monthly .............. 80-81

gage heights.................. 8

rating table................... 80

Oneida Creek at-

Kenwood, N. Y.:

description............... 70

gage heights.................. 70

Oneida River near-

Euclid, N. Y.:

description. . . . . . . . . . . . . . .

discharge

discharge, daily .................

discharge, monthly
Ontario, Lake, drainage: Page.

general features.................... 54

station data. ................. 54.78

Oswegatchie River near-

Ogdensburg. N. Y.:

description.................. 79

discharge..................... 79

, discharge, monthly............... $<0-\varepsilon 1$

gage heights................... is

rating table....................

Oswegatchie River basin:

description................... $78-79$

Oswego River at-

Battle Island, N. Y.: description........... $62-63$

discharge, monthly ............... 63

gage heights ................... 63

rating table.................... 63

Oswego River basin:

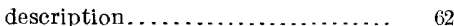

otter Creek at-

Middlebury, Vt.:

description.................... 87

discharge...................... 87

discharge, monthly .............. $\quad 89$

gage heights . . . . . . . . . .

rating table................... 88

$\mathbf{P}$.

Padgett, II. D., work of............... 1

Peshtigo River at-

Crivitz, Wis.:

description................... 20-21

discharge.................... 21

gage heights .................... 21

Herman's farm, near C'ivitz, Wis.: description................... 21-2y

discharge....................... 22

discharge, monthly .............. 22

gage heights ..................... 22

rating table...................... 22

Peshtigo River basin: description.

Plattsburg, N. Y.,

Saranac River near:

description.................. $\quad 86$

discharge, daily................ $\quad 86$

discharge, monthly.............. 8

Price current meter, views of . . . . . . . . . . . . 10

Pulaski, N. Y.,

Salmon River near: description....................... 73

discharge........................ 73

discharge, monthly.............. $\quad$ i4

gage heights.....................

rating table.................... 74

R.

Raquette River at-

Massena Springs, N. Y.:

description .................. 82

discharge..................... 82

discharge, monthly ............. 83

gage heights.................... $82-83$

rating table..................... 83

Raquette River basin:

description................... 81-82

Rating tables, construction of . . ......... 13-15 
Reed's springs near-

Albion, Mich.:

description...

gage heights and discharge..........

Reincking, V. II., work of . . . . . . . . . . . .

Richelieu River at-

Fort Montgomery, N. Y.:

description..........
discharge, monthly.

gage heights ............

rating table.

Richmond, vt.,

Winooski River at:

description.

discharge....

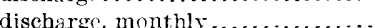

gage heights....................

rating table...

Rifie River near-

Sterling, Mich.:

description................... 38

discharge.................... $\quad 38$

gage heights . . . . . . . . . . . . . . $38-39$

Rifle River basin:

description.................... 38

Rochester, N. Y.

Genesee River at:

description.

discharge ................... 58

discharge, monthly............. 60

gage heights.................. 58

rating table.................... $\quad 59$

Run-off, computation of ................. 13-10

Run-off in inches, definition of.......... 4

Saginaw River basin:

description................... $\quad 39$

St. Joseph [of the Maumee] River at-

Fort Wayne, Ind.:

deseription. .

discharge . . . . . . . . . . . . . . . .

discharge, monthly..............

gage heights....................

rating table.

St. Joseph River near--

Buchanan, Mich.

description.................... $2 \vec{t}$

discharge, daily................ $27-28$

discharge, monthly .............. 28

Mendon, Mich.

description.................... 27

discharge..................... $\quad 27$

St. Joseph River basin:

description.....

St. Lawrence River drainage:

general features....................... is

station data ...................... $78-91$

St. Marys River at-

Fort Warne. Ind.

deseription .....................

discharge..................

discharge, monthly..............

gage heights.

rating table.
Salmon River near- Page.

Pulaski, N. Y.:

description........... 73

discharge.................... 73

discharge, monthly............. 74

gage heights................... $73-74$

rating table.................... $\quad 74$

Salmon River basin:

deseription.

$72-73$

Saranac River near-

Plattsburg, N. Y.:

description.................... 86

discharge, daily ................ $\quad 86$

discharge, monthly .............. $\quad 86$

Second-feet per square mile, definition of ... 4

second-foot, definition of ............... 4

Seneca Lake at-

Geneva, N. Y.:

description.................... 64-65

gage heights.................. 65

Seneca River at-

Baldwinsville, N. Y.

deseription.................... 66

discharge, daily $\ldots \ldots \ldots \ldots \ldots \ldots \ldots .67$

discharge, monthly ............... 67

Shawano, Wis.,

Wolf River at Darrow's bridge near: description....................... 25

discharge.................... 25

gage heights................... 25

Wolf River at White House bridge near: deseription..................... 25 discharge...................... 26 gage heights................... 26

Sherman, Mich.,

Manistee River near:

description.................... 35

discharge....................... 35

gage heights................... 35

Sherwood, Ohio,

Maumee River near:

description.................... 44

discharge..................... 44

discharge, monthly............ s.

gage heights................... 44-45

rating table......................

Single-point method of measuring discharge, description of ..................

Skaneateles Lake outlet at-

Willow Glen, N. Y.:

description..................... 67

discharge, daily................ 68

discharge, monthly ............... 68

Slope method of measuring discharge, description of................ $7-8$

Smith, L. S., work of .................. 1

Sterling, Mich.,

Rifle River near:

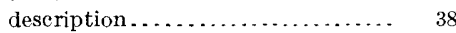

discharge ...................... 38

gage heights ..................... $38-39$

48 | Stewart,.I. F., work of .................. 
Stiles, Wis.

Oconto River at:

description.

gage heights

Stream flow, measurement and computa-

tion of.

papers on, list of

Surface water supply, papers on, list of....

\section{T.}

Tables, explanation of

Tiffin River near-

Defiance, Ohio:

description.

discharge..................... $\quad 49$

discharge, monthly............... 50

gage heights.................. 49

rating table.....................

Tittabawassee River at-

Freeland, Mich.:

description .................... 39

discharge....................... 39

gage heights .................. $39-40$

V.

Velocity methods of measuring discharge, description of ................ 9-13

Vertical-integration method of measuring discharge, description of........
W.

Page.

Water power, calculation of .............

Water supply, surface, papers on, list of .... 2-2-3

Weir method of measuring discharge. description of ................. $8-9$

Willow Glen, N. Y.,

Skaneateles Lake outlet at:

description..................... 67

discharge, daily.................. 68

discharge, monthly .............. 68

Winooski River at-

Richmond, Vt.:

description.................... 89

discharge.................... 88

discharge, monthly ............... 91

gage heights.................... 90

rating table....................... 91

Wolf River at-

Darrow's bridge near Shawano, Wis.: description..................... 25

discharge...................... 25

gage heights.................... 25

White House bridge near Shawano, Wis.: description................... 25 discharge...................... 20 gage heights................... $\quad 26$

Wolf River basin: description... 


\section{CLASSIFICATION OF THE PUBLICATIONS OF THE INITED STATES GEOLOGICAL}

SURVEY.

[Water-Supply Paper No. 20i.]

The fublications of the United States Geological Survey consist of (1) Annual Reports, (2) Monographs, (3) Professional Papers, (4) Bulletins, (5) Mineral Resources, (6) Water-Supply and Irrigation Papers, (7) Topographic Atlas of Cnited States-folios and separate sheets thereof, (8) Geologic Atlas of Cnited States-folios thereof. The classes numbered 2, 7 , and 8 are sold at cost of publication; the others are distributed free. A circular giving complete lists can be had on application.

Most of the above publications can be obtained or consulted in the following ways:

1. A limiter number are delivered to the Director of the Survey, from whom they can be obtained, free of charge (except classes 2, 7 , and 8 ), on application.

2. A certain number are delivered to Senators and Representatives in Congress, for distribution.

3. Other copies are deposited with the Superintendent of Documents, Washington, D. C., from whom they can be had at practically cost.

4. Copies of all Government publications are furnished to the principal public libraries in the large cities throughout the Cnited States, where they can be consulted by those interested.

The Professional Papers, Bulletins, and Water-Supply Papers treat of a variety of subjects, and the total number issued is large. They have therefore been classified into the following series: A, Economic geology; B, Descriptive geology; C, Systematic geology and paleontology; D, Petrography and mineralogy; E, Chemistry and physics; F, Geography; G, Miscellaneous; H, Forestry; I, Irrigation; J, Water storage; K, Pumping water; L, Quality of water; M, General hydrographic investigations; N, Water power; O, Underground waters; P, hydrographic progress reports.

Series P.-The hydrographic progress reports contain the results of stream measurements. A report is issued for every calendar year, containing the results of data collected during that year. These reports were first published as a part of the Director's annual report or as a bulletin: they are now published as water-supply and irrigation papers. The following is a list, by years, of the publications containing the progress reports of stream measurements (* means out of stock). A detailed index of these reports (1888-1903) is published as Water-Supply Paper No. 119.

1888. Tenth Annual Report, Part II*.

1889. Eleventh Annual Report, Part II*.

1890. Twelfth Annual Report, Part II*.

1891. Thirteenth Annual Report, Part III*.

1892. Fourteenth Annual Report, Part II*.

1893. Bulletin No. 131*.

1894. Bulletin No. 131*; Sixteenth Annual Report, Part II*.

1895. Bulletin No. 140*.

1896. Water-Supply Paper No. 11*: Eighteenth Annual Report, Part IV*.

1897. Water-Supply Papers Nos. 15* and 16*; Nineteenth Annual Report, Part IV*.

1898. Water-Supply Papers Nos. 27* and 28*; Twentieth Annual Report, Part I ${ }^{*}$.

1899. Water-Supply Papers Nos. $35^{*}, 36^{*}, 37^{*}, 38^{*}$, and 39*; Twenty-first Anuual Report, Part IV*. 1900. Water-Supply Papers Nos. 47, 48, 49, 50, 51, and 52; Twenty-second Annual Report, Part IV. 
1901. East of Mississippi River, Water-Supply Papers Nos. 65* and 75*. West of Mississippi River, Water-Supply Papers Nos. 66 and 75*.

1902. East of Mississippi River, Water-Supply Papers Nos. 82 and 83. West of Mississippi River, Water-Supply Papers Nos. 84 and 85.

1903. East of Mississippi River, Water-Supply Papers Nos. 97 and 98. West of Mississippi River, Water-Supply Papers Nos. 99 and 100.

1904. East of Mississippi River, Water-Supply Papers Nos. 124, 125, 126, 127, 128, and 129. West of Mississippi River, Water-Supply Papers Nos. 130, 131, 132, 133, 134, and 135.

1905. East of Mississippi River, Water-Supply Papers Nos. 165*, 166*, 167, 168*, 169, 170, and 171. West of Mississippi River, Water-Supply Papers Nos. 171, 172*, 173*, 174, 175*, 176, 177, and 178 .

1906. East of Mississippi River, Water-Supply Papers Nos. 201, 202, 203, 204, 205, 206, and 207. West of Mississippi River, Water-Supply Papers Nos. 207, 208, 209, 210, 211, 212, 213, and 214.

Correspondence should be addressed to

The Director,

United States Geological Survey,

JULY, 1907.

Washington, D. C. 